\title{
Disciplines met dadendrang : gezondheidsethiek en gezondheidsrecht in het Nederlandse euthanasiedebat 1960-1994
}

Citation for published version (APA):

Kater, L. (2002). Disciplines met dadendrang : gezondheidsethiek en gezondheidsrecht in het Nederlandse euthanasiedebat 1960-1994. [Doctoral Thesis, Maastricht University]. Aksant. https://doi.org/10.26481/dis.20021220lk

Document status and date:

Published: 01/01/2002

DOI:

10.26481/dis.20021220lk

Document Version:

Publisher's PDF, also known as Version of record

Please check the document version of this publication:

- A submitted manuscript is the version of the article upon submission and before peer-review. There can be important differences between the submitted version and the official published version of record.

People interested in the research are advised to contact the author for the final version of the publication, or visit the DOI to the publisher's website.

- The final author version and the galley proof are versions of the publication after peer review.

- The final published version features the final layout of the paper including the volume, issue and page numbers.

Link to publication

\footnotetext{
General rights rights.

- You may freely distribute the URL identifying the publication in the public portal. please follow below link for the End User Agreement:

www.umlib.nl/taverne-license

Take down policy

If you believe that this document breaches copyright please contact us at:

repository@maastrichtuniversity.nl

providing details and we will investigate your claim.
}

Copyright and moral rights for the publications made accessible in the public portal are retained by the authors and/or other copyright owners and it is a condition of accessing publications that users recognise and abide by the legal requirements associated with these

- Users may download and print one copy of any publication from the public portal for the purpose of private study or research.

- You may not further distribute the material or use it for any profit-making activity or commercial gain

If the publication is distributed under the terms of Article 25fa of the Dutch Copyright Act, indicated by the "Taverne" license above, 
DISCIPLINES MET DADENDRANG 


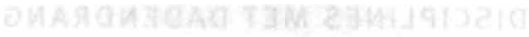<smiles>C1CCC1</smiles> 


\title{
DISCIPLINES MET DADENDRANG
}

\author{
Gezondheidsethiek en gezondheidsrecht \\ in het Nederlandse euthanasiedebat \\ $1960-1994$
}

\section{PROEFSCHRIFT}

ter verkrijging van de graad van doctor aan de Universiteit Maastricht, op gezag van de Rector Magnificus, prof. dr. A.C. Nieuwenhuijzen Kruseman

volgens het besluit van het College van Decanen, in het openbaar te verdedigen op vrijdag 20 december 2002 om 12.00 uur

door:

Loes Kater

geboren op 3 december 1971 te Deventer 


\section{Promotores:}

Prof. dr. G.A.M. Widdershoven

Prof. dr. C. Spreeuwenberg

\section{Co-promorores:}

Dr. R. H. Hourepen

Prof. dr. K. Horstman

Beoordelingscommissie:

Prof. dr. F.C.B. van Wijmen (voorzitter)

Prof. dr. R.H.J. ter Mculen

I)r. M.J. Trappenburg (Universircir Utrecht)

Prof. dr. R. de Wilde

Dr. D.L. Willems (Universiteit van Amsterdam)

Omslag: Polka design

Deze uitgave is mogelijk gemaakr dankzij de financiële bijdragen van de Faculteit der Gezondheidswetenschappen, Universiteit Maastricht, de Onderzoeksschool Wetenschap, Technologie en Moderne Cultuur en de J.E. Jurriaanse Stichting. 
I Gezondheidsethiek en gezondheidsrecht als disciplines I Proto-juridisering van de ethick? I

Opkomst en ontwikkeling 4

De empirische wending in de reflectic op wetenschap 6

Sociologisch onderzoek naar ethiek en recht 8

Het euthanasiedebat als casus i3

Vervolg van het boek 15

2 Een kennismaking met recht en ethiek in de gezondheidszorg 17 Twee normatieve vakgebieden 18

- Institutionalisering van ethiek en recht 18

- Handboeken, verenigingen en tijdschriften 20

Gezondheidsrecht 24

- Medisch recht, sociaal-hygienisch recht en gezondheidsrecht 24

- Groei en ontwikkeling van het gezondheidsrecht 26

Gezondheidsethiek 28

- Medische ethiek, ethiek van de gezondheidszorg, gezondheidsethiek en bio-ethiek 28

- Kritische geluiden $3 \mathrm{I}$

De relatie tussen gezondheidsethiek en gezondheidsrecht 34

Ontwikkeling van en verhouding tussen disciplines 38

3 Definities, afbakening en strijd bij kwesties rond het levenseinde 41 Theoretisch kader 42

Kiezen tussen verlengen of niet verlengen van het leven 45

- Geen 'verlenging' van het leven en artikel 293 Wetboek van Strafrecht

- Afzien van of ophouden met medische behandeling? 49

- Medische macht 53

'Schijngestalten' van euthanasie 56

- Zeggenschap over medisch-ethische vragen 56

- Actieve en passieve euthanasie 6I

Wat geldt als 'normaal medisch handelen'? 67

- Een 'objectieve' definitie en versmalling van de discussie 67

- Levensbeëindiging 'op verzoek' en 'zonder verzoek' 70

Het recht van spreken bij vragen rond het levenseinde 75 
4 De rol van de patiënt bij levensbeëindigend handelen: een ontwikkeling in denkstijlen en paradigmata 79 Theoretisch kader 8I

Twee denkstijlen 85

- De patiënt en het naderend einde 85

- Het verzoek van de patiënt 90

Een paradigma: de autonome patiënt 93

- Betekenis van het concept zelfbeschikking 93

- Zelfbeschikking als norm 97

Een anomalie: de wilsonbekwame patiënt roo

- Levensbeëindiging bij wilsonbekwamen; een lastig puzzelstukje 100

- Alternatieve argumenten en denkstijlen ros

Medisch-ethisch denken in het licht van wisselende denkstijlen IO9

5 Normering en regulering van levensbeëindigend handelen ${ }_{13}$ Theoretisch kader in6

De praktijk van levensbeëindigend handelen: een heterogene orde

- Voorwaarden, adviezen en een rechtszaak II

- Zorguuldigheidseisen voor het toepassen van euthanasie 122

Artsen, strafbaarheid en rechtsonzekerheid I25

- Een juridische grondslag voor het straffeloos kunnen toepassen van euthanasie 125

- Een twistpunt rond de regulering van euthanasie $\quad \mathrm{I} 28$

Nieuwe koppelingen in het netwerk rond levensbeëindigend handelen $\quad 132$

- Een uniforme meldingsprocedure voor medische beslissingen rand het levenseinde $\mathrm{I} 32$

- De elasticiteit van de zorgvuldigheidseisen 135

Knooppunten en netwerken 138

\section{Slotbeschouwing 143}

Gezondheidsrecht en gezondheidsethiek: interactie 144

De kracht van het meervoudig theoretisch perspectief:

de zaak Brongersma als voorbeeld 149

Lopen ethiek en recht achter de feiten aan?

Noten 159

Literatuur $\quad 177$

Summary 195

Samenvatting 201

Dankwoord 207

Curriculum Vitae 2ro 


\section{GEZONDHEIDSETHIEK EN GEZONDHEIDSRECHT}

\section{ALS DISCIPLINES}

\section{Proto-juridisering van de ethiek?}

In 1996 stond de jaarlijkse workshop van de Koninklijke Nederlandse Akademie van Wetenschappen (KNAw), georganiseerd door de Commissie Geneeskunde, geheel in het teken van de gezondheidsethiek en het gezondheidsrecht. In de inleiding tot deze workshop werd betoogd dat deze normatieve disciplines grote relevantie hebben voor de geneeskunde, maar dat de bekendheid onder de meeste medici met deze disciplines gering was. 'Voor vele medici practici zal het zo zijn, dat het gekozen onderwerp geen gemakkelijke handvatten heeft. Voor een deel ligt dit waarschijnlijk aan het feit dat het hier normatieve disciplines betreft, waarbij medici tot voor kort nauwelijks of niet in hun opleiding werden geconfronteerd. (...) Het is momenteel algemeen geaccepteerd dat gezondheidsethiek en gezondheidsrecht niet meer uit de geneeskunde zijn weg te denken' (Putte 1997). De huidige generaties geneeskundestudenten maken namelijk tijdens hun opleiding al kennis met gezondheidsethiek en gezondheidsrecht (Ten Have \& Van Wijmen et al. 1994; Van Wijmen \& Ten Have et al. 1994).

Gezondheidsethiek en gezondheidsrecht zijn twee relatief jonge vakgebieden aan universiteiten; de opkomst van beide disciplines wordt in Nederland rond 1960 gelokaliseerd. Tot die tijd hebben gedrags- en beroepscodes het handelen van artsen gereguleerd. Deze vielen onder de noemer medische ethiek. De in de tijd van de oude Grieken geïntroduceerde eed van Hippocrates had betrekking op normen en regels voor artsen dic ruim tweeduizend jaar geleden de geneeskunde uitoefenden. Deze omstandigheden zijn uiteraard in de verste verte niet vergelijkbaar met de recente medische praktijk. De huidige normen en regels bestrijken bijvoorbeeld een breder terrein dan de strekking van de eed. Aandacht voor de positie van de arts is daarbij slechts één van de vele facetten. Onderwerpen en terreinen waar de gezondheidsethiek en het gezondheidsrecht zich bijvoorbeeld over buigen zijn: ontwikkelingen in de genetica, ontwikkelingen in de voortplantingstechnologie, de schaarste in de zorg, de arts-patiëntrelatie en de problematiek rond het einde van het leven.

Ethiek en recht hebben zich als disciplines op de (medische) landkaart geplaatst. Hoe zijn ze daarin geslaagd? Eind jaren zestig klonk in Nederland de roep om de medische 'macht' in te dammen. Daarmee werd gerefereerd aan een 
aantal ontwikkelingen op het terrein van de medische technologie en de medische wetenschap. Artsen zouden een te dominante positie hebben gekregen; paternalisme kreeg een nare bijsmaak. Theologen, filosofen, juristen en ook artsen hebben veel werk verzet in een poging de medische macht in banen te leiden. In de jaren zeventig werden diverse leerstoelen 'medische ethiek' in het leven geroepen, veelal gelieerd aan een faculteit der geneeskunde. In 1977 verscheen het Tijdschrift voor Gezondheidsrecht voor het eerst. In de jaren tachtig werden er tijdschriften uitgegeven die zich specifiek richtten op geneeskunde en filosofie. Vlak daarna volgde een oprichtingsgolf van diverse centra: het Instituut voor Gezondheidsethiek in Maastricht (1984), het Utrechtse Centrum voor Bio-ethiek en Gezondheidsrecht (1987) en het Centrum voor Ethiek van de Katholieke Universiteit Nijmegen (1993). Ethici en juristen namen zitting in vele (toetsings)commissies en bouwden aan hun netwerk door zich te verenigen. Bijvoorbeeld in de Vereniging voor Gezondheidsrecht en de Nederlandse Vereniging voor Bio-ethiek.

Uit bovenstaande kan de conclusie worden getrokken dat de ontwikkeling van ethiek en recht in de gezondheidszorg een geslaagd project is. In relatief korte tijd hebben beide disciplines zich een plek binnen de geneeskunde verworven en zich ook dienstbaar getoond ten opzichte van de geneeskunde. Die conclusie is echter wat te gehaast. Ethici zijn bijvoorbeeld niet onverdeeld tevreden over de ontwikkelingen. Sinds eind jaren tachtig van de vorige eeuw is de gezondheidsethiek in Nederland aan felle kritiek onderworpen. In dit voornamelijk interne debat onder ethici wordt kritiek geuit op de 'dominante ethiek'. Eén manier om dit debat te karakteriseren is te stellen dat ethici die een 'brede' ethiek voorstaan, de degens kruisen met ethici die een 'smalle' ethiek voorstaan. Deze zogenoemde smalle ethiek wordt ook wel aangeduid als regelethiek. Voorstanders van de brede ethiek zetten zich tegen af tegen een smalle, toegepaste vorm van ethiek (Zwart 1992; Achterhuis 1993). Onder 'smalle ethiek' wordt verstaan het toepassen van algemene ethische beginselen op problemen in de medische praktijk. Deze deductieve vorm van ethiek zou vooral oplossingsgericht zijn. Een 'brede ethiek' zou daarentegen meer gericht zijn op het begrijpen en interpreteren van de moraal in de gezondheidszorg. Hierbij gaat het om een kritische filosofische reflectie op de praktijk van de gezondheidszorg. De verschillen worden een aantal jaren later zo fundamenteel geacht dat over een richtingenstrijd wordt gesproken (Reinders 1997). Maar ook onder voorstanders van een bredere visie op ethiek bestaan weer verschillende ideeën over de invulling van die bredere ethiek. Zo worden bijvoorbeeld de fenomenologische benadering, de narratieve benadering en de zorgethische benadering van echiek onderscheiden (Widdershoven 200o).

Ethici en sociale wetenschappers hebben zich kritisch uitgelaten over de functie van de ethiek en de richting die de ethiek is ingeslagen (Zwart 1995; De 
Vries 1993a). Volgens een aantal van deze kritische geluiden is de - dominante ethiek teveel omgebogen naar het recht. Sommige ethici hebben zich volgens critici te zeer een juridische denkstijl aangemeten. Gesproken wordt over een reductionistische ethiek, omdat ethici zich zouden beperken tot het redeneren in termen van rechten en plichten. Het zogenoemde 'contract-model' zou exemplarisch zijn voor deze ethiek. In het contractuele denken staan noties als gelijkheid, onpartijdigheid, rationaliteit en neutraliteit centraal (Verkerk 1994). Dit zou onder andere kunnen betekenen dat morele en juridische afwegingen daardoor niet meer scherp van elkaar te onderscheiden zijn.

Het verschijnsel waar in bovenstaand debat naar wordt verwezen - met uitspraken over de versmalling van de ethiek, minimalisering van de ethiek, ethiek gereduceerd tot de smalle moraal en ethiek als probleemoplosser, proceduralisme - wordt in dit boek aangeduid als proto-juridisering van de ethiek.' Er zijn kleine nuances aan te wijzen tussen de verschillende kritieken, maar grofweg zitten ze op dezelfde golflengte. Bij versmalling en minimalisering van de ethiek wordt kennelijk verondersteld dat er eerst een bredere ethiek zou hebben bestaan, dan wel dat die bredere ethiek de norm zou zijn. De aanklacht luidt dat (sommige) ethici in hun beschouwingen (al) zouden anticiperen op juridische regelingen en daarmee voorbijgaan aan de fundamenteel ethische discussies. Het mikpunt van alle kritiek is de huidige dominante gezondheidsethiek. Om verwarring te voorkomen wordt hier niet de term juridisering gebruikt. Een aantal auteurs duidt met deze term namelijk de relatie aan tussen gezondheidsrecht en de medische prakrijk. ${ }^{2}$

Bovenstaande observaties over proto-juridisering van de ethiek zijn mede aanleiding voor dit onderzoek naar de ontwikkeling en verhouding van de disciplines gezondheidsethiek en gezondheidsrecht geweest. Hoe gaat het eraan toe in de praktijk van de (toegepaste) ethiek en het (toegepaste) rechr? ${ }^{3}$ Welk werk is er verricht om tot de ontwikkeling en afbakening van de beide disciplines te komen? Het thema van de proto-juridisering van de ethiek zet ook de relatie tussen ethiek en recht op de agenda. Tenslotte, hoe is de inhoudelijke ontwikkeling bij beide disciplines tot stand gekomen? Om deze vragen te kunnen beantwoorden wordt een historische reconstructie gemaakt vanuit verschillende perspectieven. Het onderzoek vertrekt vanuit het theoretisch uitgangspunt dat grenzen en afbakeningen tussen disciplines contingent en veranderlijk zijn. Dit uitgangspunt impliceert dat er geen sprake is van een autonome ontwikkeling voor beide vakgebieden. Het onderhavige onderzoek is geen partij in het debat over de dominante gezondheidsethiek of over het professionele debat over de functie, plaats en verhouding van recht en ethiek. Deze ideeën over gezondheidsethiek en gezondheidsrecht vormen juist de aanleiding voor het onderzoek. Het boek heeft wel een boodschap voor dit debat. Deze boodschap zal in de conclusie nader worden uitgewerkt. 
In dit hoofdstuk wordt de vraagstelling van het onderzoek verder toegelicht. De volgende twee paragrafen gaan in op het belang van historisch onderzoek naar de disciplines recht en ethiek en de betekenis van de empirische wending in de reflectie op wetenschap. De daarop volgende paragraaf schetst een aantal verwante sociologische studies over ethiek en recht. Het merendeel van deze studies heeft betrekking op de situatie in de Verenigde Staten. De één na laatste paragraaf gaat in op de vorm van het onderhavige onderzoek; een casestudy. Het empirisch materiaal dat de basis vormt voor deze studie heeft betrekking op het professionele debat over euthanasie in Nederland. Tenslotte wordt de opbouw van het boek toegelicht.

\section{Opkomst en ontwikkeling}

In zijn bijdrage aan de eerder genoemde workshop van de KNAw gaf de socioloog Schuyt een korte sociologische verkenning van gezondheidsrecht en gezondheidsethiek. Ten eerste vroeg hij zich af wat de maatschappelijke achtergronden zijn van de opkomst van recht en ethiek als disciplines op het terrein van de geneeskunde. Ten tweede luidde zijn vraag in hoeverre deze ontwikkelingen in de samenleving als verklaringen voor de opkomst van beide disciplines kunnen dienen. Om deze vragen te beantwoorden maakte Schuyt gebruik van uitgangspunten in de wetenschapssociologie. 'In de wetenschapssociologie is het gebruikelijk geworden om wetenschappelijke disciplines zowel vanuit een internalistisch, dat wil zeggen vanuit min of meer autonome ontwikkelingen binnen een of meerdere vikgebieden te verklaren, als ook vanuit cen externalistisch gezichtspunt' (Schuyt 1997). Een internalistische verklaring heeft in dit geval betrekking op cognitieve aspecten die een rol spelen bij de ontwikkeling van een discipline. Een externalistische verklaring heeft betrekking op sociale aspecten. Er worden dan maatschappelijke factoren aangegeven, die de drijvende krachten achter het ontstaan van de discipline zouden zijn.

Schuyt beperkte zich tot het geven van voorbeelden en observaties van internalistische en externalistische verklaringen. Hij stelde dat disciplines een interne dynamiek van vraagstelling en domeinvergroting hebben. Ten eerste zou het aanbod van filosofen de vraag naar medisch-ethische kwesties scheppen. Ten tweede dichtte Schuyt juristen 'de vrolijke eigenschap' toe om 'van een probleem een interessante rechtsvraag te maken' (p. I8). In het rijtje van externe of maatschappelijke factoren werden door Schuyt de volgende vijf aspecten genoemd: technologische ontwikkelingen, medische schaarste, de eindeloze vraag naar gezondheid, de vraag naar geestelijke gezondheidszorg en de afwezigheid van een gedeelde moraal van bijvoorbeeld aanpassing en berusting (p. 19). Schuyt stelde dat 'empirisch-historisch onderzoek hoé en wannéér disciplines 
tot wasdom zijn gekomen' nodig is om op bovenstaande vragen uitgebreider antwoord te kunnen geven (p. 17).

Schuyt zette interessante vragen op de agenda, maar er zijn kanttekeningen te plaatsen bij zijn sociologische benadering. De impliciete vooronderstelling van deze benadering is dat er een onafhankelijk criterium zou bestaan, waarmee de wereld kan worden ingedeeld in cognitieve factoren enerzijds en sociale factoren anderzijds. Het internalistische perspectief veronderstelt namelijk dat er een (vast) idee zou bestaan wáár ethiek en recht precies over gaan. Het externalistische perspectief veronderstelt dat de inhoud van de vakgebieden is afgeleid van sociale factoren. In dit onderzoek wordt er vanuit gegaan dat een dergelijk strikt onderscheid tussen cognitieve en sociale factoren niet te maken is. In empirisch-historisch onderzoek naar de ontwikkeling van beide disciplines is het juist interessant om de interactie tussen deze factoren te bestuderen.

Het idee van een gegeven of vaststaande identiteit van disciplines heeft, sinds de constructivistische wending in de wetenschapstheorie, aan geloofwaardigheid ingeboet. Wetenschapsonderzoek gaat ervan uit dat de identiteit van een discipline niet gezocht moet worden in de aard van het object, een exclusieve invalshoek of in het type problemen die het behandelt, maar in de geschiedenis van die discipline (De Wilde 1992). Een discipline heeft geen van 'nature' gegeven identiteit, maar verwerft deze door de inspanningen van verschillende actoren. De Wilde heeft in een onderzoek naar het ontstaan van sociologie als discipline betoogd, dat er veel werk is verzet door sociologen om hun vak een eigen identiteit te geven. Bovendien hebben niet alle intenties van betrokkenen uitgepakt zoals ze bedoeld waren. Succes is niet alleen afhankelijk van de intenties van personen, maar van de effecten van hun handelingen. Het is bijvoorbeeld niet vanzelfsprekend, dat er naast geschiedenis en economie ook een discipline sociologie is gevormd. De grens tussen wetenschap en nietwitenschap zou volgens De Wilde niet door de historicus moeten worden getrokken, maar historisch worden gereconstrueerd. In dit onderzoek wordt eveneens uitgegaan van een dergelijk constructivistisch wetenschapsbeeld. Dit veronderstelt dat het niet mogelijk is om vooraf een onderscheid te maken tussen verschillende soorten factoren; dir onderscheid wordt tijdens het proces door de actoren zelf gemaakt en is pas achteraf, aan de hand van gedetailleerd onderzoek, te herkennen. Een dergelijk onderscheid kan dan ook niet als heuristiek dienen voor empirisch onderzoek naar de ontwikkeling van disciplines.

In deze studie gaat het niet alleen om de geschiedenis van de disciplines gezondheidsethiek en gezondheidsrecht, maar ook over de verhouding tussen beide vakgebieden. Hierover is door verscheidene Nederlandse ethici, juristen en sociologen in de afgelopen jaren gepubliceerd (Ten Have \& Vroom-Kastelein 1987; Leenen 1988b; Van der Burg \& Ippel 1994; Schuyt 1995; Schuyt 1997; 
Roscam Abbing \& Dillmann 1997). In deze literatuur zijn verschillende claims te lezen over hoe de relatie gezondheidsethiek-gezondheidsrecht er uitziet, dan wel uit zou moeten zien. Sommige auteurs eisen een specifiek eigen domein op voor elk van de disciplines. Zij legitimeren deze claim door te stellen dat de methodiek en het vocabulaire van gezondheidsethici en gezondheidsjuristen aanzienlijk verschillen. Andere auteurs stellen dat er sprake is van zoveel overeenkomsten, dat het aangeven van een duidelijke afbakening een onmogelijke taak is. Als voorbeelden voor overeenkomsten noemen ze de grote voorliefde voor casuïstiek en het werken vanuit dezelfde beginselen, bijvoorbeeld respect voor autonomie. Deze claims hebben gemeen dat ze een a-historisch perspectief schetsen op de relatie tussen recht en ethiek. De huidige stand van zaken wordt niet gerelativeerd door een historische invalshoek. Bovendien getuigt deze literatuur van een essentialistisch beeld van beide vakgebieden. De ethiek ziet er nu eenmaal op deze manier uit en het recht op die manier. Daarom zijn ze ofwel verschillend ofwel sterk met elkaar verstrengeld. Dit onderzoek wil laten zien dat de rolverdeling tussen de beide disciplines geenszins voor zich spreekt en dat er niet vanzelfsprekend twee afgebakende domeinen bestaan. Met het markeren van grenzen gaat een aanzienlijke hoeveelheid arbeid gepaard.

Het doel van deze studie is inzicht krijgen in de ontwikkeling van en verhouding tussen gezondheidsethiek en gezondheidsrecht. Dit inzicht zou verder moeten reiken dan de kennis die op basis van het zelfbeeld van beide disciplines kan worden verkregen. Hiervoor is empirisch-historisch onderzoek verricht naar de disciplines recht en ethiek. Daarbij zijn meerdere theoretische perspectieven als heuristiek gebruikt. Er is gebruik gemaakt van inzichten uit respectievelijk de professiesociologie, de wetenschapsgeschiedenis en het sociologische wetenschapsonderzoek. De drie gekozen invalshoeken vormen een analytisch hulpmiddel om de vraag naar de constructie van de disciplines en hun onderlinge relatie te kunnen beantwoorden. Het onderzoek heeft niet de pretentie een 'compleet' beeld te geven van de ontwikkelingen in recht en ethiek. Dit zal in de volgende paragraaf nader worden toegelicht.

\section{De empirische wending in de reflectie op wetenschap}

Sinds de jaren vijftig, zestig en zeventig is in de wetenschapstheorie het idee uitgekristalliseerd dat we afscheid zouden moeten nemen van de vooronderstelling dat wetenschap ons objectieve feiten brengt. Historisch-sociologische reflecties hebben er voor gezorgd dat het ideaal van een 'waardevrije' wetenschap op afstand is komen te staan. Met name het werk van Kuhn en ook van Fleck heeft hieraan een bijdrage geleverd (Kuhn 1962; Fleck 1980). Hun werk markeert een verschuiving in het denken over wetenschap en wetenschapsont- 
wikkeling. Sindsdien is er in de reflectie op wetenschap sprake van een combinatie van filosofisch, historisch en sociologisch onderzoek en van een empirische wending. Dat betekent dat reflectie werd gebaseerd op empirische en historische voorbeelden van verschillende manieren waarop onderzoekers in de praktijk omgaan met keuzen en criteria. Het onderzoek van Kuhn is door wetenschapssociologen in de jaren zeventig gebruikt toen ze zich begonnen af te zetten tegen het programma van de socioloog Merton (Hagendijk 1996). Merton had in de jaren veertig een programma ontwikkeld dat zich richtre op onderzoek naar de sociaal-culturele organisatie van wetenschapsbeoefening. Dit leidde in de jaren vijftig en zestig tot een onderwaardering van de cognitieve aspecten van wetenschappelijke kennis in de wetenschapssociologie (Zuckerman 1988). Geïnspireerd door het werk van Kuhn hebben sociologen en historici in de jaren zeventig, als tegenreactie op het Mertoniaanse programma, de inhoud van wetenschapsbeoefening zelf en de veranderingen daarin op de onderzoeksagenda gezet. Dit heeft tot diverse stromingen in het wetenschapsonderzoek geleid (Hagendijk 1996).

Kenmerkend voor het moderne wetenschapsonderzoek is de nadruk op de interactie tussen wetenschappelijke en maatschappelijke ontwikkelingen. In het wetenschapsonderzoek staat het bestuderen van wetenschappelijke en maatschappelijke praktijken centraal. Er wordt onder andere gebruik gemaakt van noties als demarcatiearbeid en grenzenwerk (Gieryn 1983, 1999). Deze begrippen vormen een gemeenschappelijke interesse van wetenschapsonderzoek en professiesociologie. De interesse voor kennissystemen in relatie tot verandering van maatschappelijke praktijken en professieontwikkeling vormt het gemeenschappelijke element van de drie empirische hoofdstukken. Zowel in de professiesociologie, de wetenschapssociologie als in het wetenschapsonderzoek wordt er vanuit gegaan dat wetenschap als een sociale praktijk kan worden beschouwd. Het empirisch onderzoek naar wetenschappelijke praktijken, zoals gepresenteerd in hoofdstuk drie, vier en vijf, veronderstelt dan ook dat wetenschap een maatschappelijk verschijnsel is dat met behulp van de ingezette heuristieken bestudeerd kan worden. Toch kunnen de verschillende hoofdstukken elk ook als een zelfstandige analyse worden beschouwd.

De zeggenschapsanalyse in hoofdstuk drie moet inzicht in kritieken op de verhouding tussen recht en ethiek opleveren door terug te gaan naar het ontstaan en de ontwikkeling van de beide disciplines. De betrokken actoren claimen zeggenschap en eisen verantwoordelijkheden op of krijgen die toebedeeld. Hiermee positioneren ze zich in het debat over levensbeëindigend handelen. Deze actoren hebben veel werk moeten verzetten om een plek in het debat te krijgen en te behouden, waarbij impliciet en ook expliciet claims met betrekking tot de spreekbevoegdheid van een discipline over dilemma's rond het levenseinde worden gedaan. Hiermee worden grenzen getrokken tussen geldige 
en ongeldige, zinvolle en zinloze uirspraken. Op die manier krijgt de zeggenschap van beide disciplines vorm.

De cognitieve ontwikkeling van beide vakgebieden wordt in hoofdstuk vier met behulp van de concepten denkstijl en paradigma bestudeerd. Beide disciplines zijn tot ontwikkeling gekomen in een fase waarin het oude paradigma van de medische ethiek - de beroepscodes - in twijfel werd getrokken. Er rezen twijfels over de geldigheid en houdbaarheid van het idee van de paternalistische arts. Hoewel voortgekomen uit verschillende moederdisciplines blijken beide disciplines aanvankelijk een gemeenschappelijk denkkader te hebben. Een aantal overeenkomsten in het begrippenkader van ethiek en recht kan dus in deze context begrijpelijk worden gemaakt.

In de netwerkanalyse van hoofdstuk vijf wordt met behulp van inzichten binnen het wetenschapsonderzoek het idee van een vaste verhouding tussen recht en ethiek ter discussie gesteld. De ontwikkeling van recht en ethiek en de verhouding tussen normatieve oordeelsvorming en regulering is dan niet als een vanzelfsprekende rolverdeling te beschouwen, maar als een resultaat van netwerkvorming. Binnen dit netwerk zijn de zorgvuldigheidseisen, die in een notendop de normering en regulering voor euthanasie vormen, een belangrijk knooppunt. De meerwaarde van deze drie exercities is dat de drie perspectieven moeten leiden tot een scherper inzicht in de ontwikkeling van en relatie tussen recht en ethiek. Recht en ethiek zijn niet eenduidig te definiëren, maar kunnen slechts in een contextuele analyse tot leven komen.

\section{Sociologisch onderzoek naar ethiek en recht}

$\mathrm{Bij}$ het gros van de sociologische onderzoeken naar medische ethiek (en soms ook ethiek en recht) staat de situatie in de Verenigde Staten centraia. De Amerikaanse socioloog Weisz publiceerde in 1990 een interdisciplinair boek over ethiek vanuit sociaal-wetenschappelijk perspectief. De bijdragen voor het boek waren afkomstig van sociologen, historici, medisch antropologen en filosofen. Met het boek wilde Weisz aandacht vragen voor sociaal-wetenschappelijk onderzoek naar de medisch-ethische praktijk. Ethici zouden niet voldoende in staat zijn om dit perspectief in te nemen. Zij zouden inhoudelijk te zeer betrokken zijn bij de ethiek, waardoor ze te weinig oog hadden voor de sociale en culturele context ervan (Weisz 1990). Een veel genoemd voorbeeld in dit verband is een empirisch onderzoek van de sociologen Fox en Swazey naar ethiek van de gezondheidszorg in China begin jaren tachtig (Fox \& Swazey r984). In tegenstelling tot de veronderstelling binnen de Amerikaanse ethiek dat de daar gehanteerde principes en rechten universeel zouden zijn, concludeerden Fox en Swazey op grond van hun veldwerk in China dat er verschillen waren tussen de 
beide landen. Dit zette hen op het spoor dat Amerikaanse ethici zich niet of nauwelijks bewust schenen te zijn van het specifieke culturele karakter van hun eigen ethiek. Na deze publicatie was het thema van het 'lokale karakter' van de ethiek en internationaal vergelijkend onderzoek naar ethiek op de onderzoeksagenda gezet.

Aandacht voor de sociale en culturele context van ethische dilemma's en voor sociale en politieke conflicten vormt de kern van sociaal-wetenschappelijk onderzoek. Volgens Weisz zou sociaal-wetenschappelijk onderzoek naar de praktijk van medische ethiek drie winstpunten kunnen opleveren. Ten eerste worden ethici voorzien van empirische gegevens. Dit kan variëren van (historische) beschrijvingen van ethische debatten tot informatie over hoe mensen in verschillende culturen en op verschillende sociale niveaus zich gedragen in moeilijke ethische situaties. Ten tweede kunnen sociaal-wetenschappelijke perspectieven de traditionele ethische analyses wijzigen of aanvullen. Uit onderzoek naar informed consent in de klinische praktijk bleek bijvoorbeeld dat van geïnformeerde toestemming nauwelijks sprake is op de manier zoals voorgesteld in ethische en juridische literatuur (eerst expliciet toestemming vragen voor behandeling). Dit zou betekenen dat er opnieuw zou moeten worden nagedacht over de doctrine van informed consent. Ten derde kunnen analyses door sociale wetenschappers leiden tot zelfreflectie bij ethici en juristen, zoals bijvoorbeeld naar aanleiding van het soort onderzoek dat Fox en Swazey hebben uitgevoerd. Een dergelijk buitenstaandersperspectief werpt een nieuw licht op een gedachtegoed dat als vanzelfsprekend wordt beschouwd. Dit zou volgens Weisz ten goede komen aan de intellectuele ontwikkeling van het vakgebied (Weisz 1990). De bundel van Weisz bestaat voor het merendeel uit bijdragen met ecn macro- of micro-sociologisch perspectief op cthiek. Dit betekent dat er weinig aandacht is voor ontwikkelingen in de ethiek vanuit een historisch perspectief. Het boek is een momentopname van de stand van zaken binnen de Amerikaanse ethiek aan het eind van de jaren tachtig.

Meer aandacht voor historische ontwikkelingen is er in het boek Bio-ethics and Society van de Amerikaanse sociologen De Vries en Subedi (De Vries \& Subedi 1998). Dit boek geeft een sociologische benadering van de opkomst en organisatie van de bio-ethiek. ${ }^{4}$ Net als bij Weisz hebben auteurs afkomstig uit diverse disciplines een bijdrage geleverd aan dit boek, waarbij het sociologische perspectief de rode draad vormt. Twee vragen staan centraal: welke sociale en historische bewegingen hebben geleid tot de behoefte aan bio-ethiek en hoe effectief is bio-ethiek als nieuwe vorm van regulering? Dat levert het volgende beeld op. Ten eerste wordt de sociale context van bio-ethiek verkend. Er is onderzoek gedaan naar de achtergrond en herkomst van onder andere het idee van respect voor autonomie en informed consent binnen de Amerikaanse ethiek. Het feit dat het autonomieprincipe de laatste drie decennia als cen soort 
panacee geldt voor ethische problemen in de Verenigde Staten, wordt door Root Wolpe voor een groot deel toegeschreven aan de Amerikaanse cultuur. Met name maatschappelijke ontwikkelingen in de jaren zestig en zeventig zouden hiertoe hebben bijgedragen. Men beschouwde het autonomieprincipe van de vier ethische principes (autonomie, rechtvaardigheid, weldoen en niet schaden) als meest duidelijk en minst controversieel (Root Wolpe 1998). Ten tweede wordt er gefocust op de manier waarop ethiek als vak wordt uitgeoefend binnen klinieken, laboratoria en instituten voor bio-ethiek. Met name de rol van medisch-ethische commissies in ziekenhuizen en verpleeghuizen is nader bekeken. Deze veelal door de Amerikaanse overheid vereiste commissies zouden een versterking van de positie van de patiënt moeten betekenen ten opzichte van de arts die anders alle macht in zijn eentje in handen heeft. Bosk en Frader achten het echter niet overtuigend bewezen dat deze multidisciplinair samengestelde commissies er wél in slagen om het machtsblok rond medisch ethische dilemma's te splijten (Bosk \& Frader 1998). Ten derde wordt er in het boek van De Vries en Subedi aandacht besteed aan de manier waarop de praktijk van de bio-ethiek functioneert. Crigger geeft bijvoorbeeld, op basis van etnografisch onderzoek, een overzicht van het werk van ethici in professionele tijdschriften van de afgelopen vijfentwintig jaar. Daaruit blijkt dat er over de genoemde periode een continue belangstelling is voor onderwerpen als abortus, orgaantransplantatie en dilemma's rondom voortplanting; dit zijn de zogenoemde 'classics'. Voor andere onderwerpen geldt dat ze een tijdje in de belangstelling staan en dan weer van het toneel verdwijnen, zoals bijvoorbeeld de vraag in hoeverre het gedrag van psychiatrische patiënten beïnvloed mag worden. Deze categorie wordt aangeduid als de 'shooting stars' (Crigger 1998). De bijdragen in het boek van De V ries en Subedi geven meer inzicht in de ontwikkelingen binnen de discipline dan de bundel van Weisz. Wat opvalt in het boek is dat de focus volledig op bio-ethiek is gericht, zonder aandacht te schenken aan bijvoorbeeld de rol van jurisprudentie bij de ontwikkeling van bio-ethiek.

De Amerikaanse socioloog Rothman heeft historisch onderzoek verricht naar de veranderde arts-patiëntrelatie sinds de jaren zestig en heeft daarbij wél expliciet aandacht besteed aan ontwikkelingen zowel in de ethiek als het recht. Hij heeft gezocht naar oorzaken en consequenties van de veranderde relatie tussen geneeskunde en maatschappij en naar de manier waarop recht en ethiek hierbij een rol hebben gespeeld (Rothman 199r). Op basis van literatuuronderzoek en observaties schetst Rothman de transformatie van het beeld van de arts die in een kamer alleen met zijn pariënt zit, naar een overvolle kamer waarin de arts in discussie is met collega's, familie, juristen en ethici, voordat er een beslissing kan worden genomen voor de desbetreffende pariënt (van patiëntenkamer naar vergaderkamer of zoals Rothman het omschrijft: van 'bedside ethics' naar 'armchair ethics', p. 2). Deze verandering van individuele beslissingen naar col- 
lectieve beslissingen zou in de Verenigde Staten na de Tweede Wereldoorlog in gang zijn gezet. Het patiëntendossier zou als gevolg hiervan zijn veranderd van privé-document ten behoeve van de communicatie tussen artsen onderling tot een openbaar bewijsstuk voor wat de arts heeft gezegd.

Rothman concentreert zich op verschillende sociale fenomenen (afbrokkelend vertrouwen in de artsenstand, ontwikkelingen in de medische wetenschap) om zijn hypothese overtuigend en inzichtelijk te maken. De collectieve besluitvorming bereikte zijn hoogtepunt met de inmiddels beroemde Quinlan case warrin het niet meer ging om professionele besluitvorming, maar om een juridische beleidskwestie. Artsen moesten, op gezag van het hooggerechtshof van New Yersey, aan het verzoek van de ouders van de tweeëentwintig jarige in coma liggende Karen Ann Quinlan voldoen door haar van de beademingsmachine te halen. Mer deze voorbeelden maakte Rothman begrijpelijk hoe ethici en juristen betrokken zijn geraakt bij het proces van collectieve besluitvorming rond dilemma's in de geneeskunde. Artsen hebben, soms tegen wil en dank, de voorheen individuele beshuitvorming op moeten geven. Morele dilemma's worden nu in het openbaar en in samenspraak met diverse niet-medici beslist. Rothman heeft met zijn geschiedschrijving over de veranderde relatie tussen de maatschappij en de geneeskunde, op basis van sociale factoren, een verklaring gegeven voor die desbetreffende veranderingen. Hij heeft zich daarbij op een aantal bekende gebeurtenissen uit de (Amerikaanse) geschiedenis geconcentreerd.

Uit bovenstaande sociologische onderzoeken kan een aantal zaken met betrekking tot de situatic van recht en de ethiek in de Verenigde Staten worden afgeleid. In de Amerikaanse (bio) ethiek wordt de culcurele inbedding van de ethiek niet of nauwelijks erkend. Fthici beschouwen de eigen ethiek als universeel geldend. Door sociologen wordt de dominantie van het autonomieprincipe voor een groot deel toegeschreven aan 'de' Amerikaanse cultuur. Er is kennelijk consensus over het feit dat ethici en juristen, als leden van het nieuwe fenomeen medisch-ethische commissies, het proces van individuele besluitvorming door de arts naar collectieve besluitvorming rond medisch-ethische dilemma's hebben bevorderd. Niettemin bestaat er bij sommige sociologen scepsis of de aanwezigheid van ethici (en juristen) in dergelijkc medisch-cthische commissies wel een daadwerkelijke verbetering van de posirie van de patiënt betekent ten opzichte van de oude situatie waarin een arts mocilijke beslissingen op eigen houtje nam.

In tegenstelling tot de sociologie van de ethiek zijn er in de rechtssociologie nauwelijks standaardwerken voor handen, noch in de Verenigde Staten noch in Nederland. Dir is kennelijk een terrein waar weinig belangstelling voor is en dat nog grotendeels ontsloten moet worden. Dat geldt in het bijzonder voor reflexieve en historische beschouwingen waarin specifiek aandacht wordt besteed 
aan het gezondheidsrecht. ${ }^{5}$ De al eerder genoemde socioloog Schuyt heeft in de jaren negentig een aanzet gegeven voor een sociologisch perspectief op de rol en functie van het gezondheidsrecht. Volgens Schuyt verschillen de functies van het gezondheidsrecht niet zo zeer van de algemene functies die het recht vervult in onze samenleving (Schuyt 1993: 156). Traditioneel zijn er drie rollen te onderscheiden: conflictbeslechting, ordening en verdeling. Met name de laatste twee functies zouden centraal staan bij het gezondheidsrecht. Naast een beschrijving van de functies van het gezondheidsrecht heeft Schuyt ook een opvatting over de missie van het vakgebied. Hij ziet voor het gezondheidsrecht de taak weggelegd om het verschil tussen de medische en juridische wereld te overbruggen. Uit een analyse van de processen van medicalisering en juridisering van verhoudingen in de gezondheidszorg leidt Schuyt een taakopvatting voor het gezondheidsrecht in onze samenleving af. Zo zou de ontwikkeling van een vruchtbaar gezondheidsrecht bijvoorbeeld een tegenwicht kunnen bieden aan het gevaar van eenzijdige machtsrelaties tussen arts en patiënt. Hij is van mening dat het gezondheidsrecht een 'voorbeeldige rol kan spelen als contrapunt tegen een te vergaande medische of organisatorische ondermijning van de individuele rechten van de patiënt, die Leenen zo terecht in zijn werk onvervreemdbare mensenrechten heeft genoemd' (Schuyt 1993). Wil het gezondheidsrecht de zijns inziens wenselijke brugfunctie tussen de medische en juridische wereld kunnen blijven vervullen, dan zou ze medische waarden ook met juridische waarden, zoals zelfbeschikking, moeten verbinden.

De schets van het onderzoek naar ethiek en recht laat zien dat deze disciplines op verschillende manieren - bijvoorbeeld historisch of etnografisch - bestudeerd kunnen worden. Wat ontbreekt is onderzoek waarin de relatie tussen recht en ethiek wordt bestudeerd en waarin de twee disciplines niet als losse entiteiten worden beschouwd. Het onderhavige onderzoek tracht in die lacune te voorzien. Centraal staat een verkenning van de ontwikkelingen van en onderlinge relatie tussen recht en ethiek in de tweede helft van de twintigste eeuw. Het onderzoek plaatst zich in de relatief nieuwe traditie van sociologisch onderzoek naar het functioneren van ethiek en recht. Er is gebruik gemaakt van - min of meer - sociologische benaderingen; professiesociologie, wetenschapsgeschiedenis en sociologisch of constructivistisch wetenschapsonderzoek. Deze benaderingen kunnen onder de overkoepelende term 'historisch-sociologisch' onderzoek worden geschaard. De theorieën hebben een heuristische functie. Het gebruik van theorie moet voorkomen dat er sprake zal zijn van 'whighistory' (Harrison 1987). Whighistory wil zeggen dat gebeurtenissen in het verleden, die vanuit huidige inzichten minder relevant zijn, naar de achtergrond worden geschreven. Het verleden wordt in dat geval aan de maatstaf van het heden onderworpen. Een veel gehoorde klacht hiertegen is dat het verleden dan geen recht wordt gedaan. Bij historisch-constructivistisch onderzoek is het belang- 
rijk dat niet alleen de naar huidig inzicht invloedrijkste hoofdstukken uit de geschiedschrijving aandacht krijgen. Inzichten met juist op het eerste geziche een minder historische impact kunnen nieuwe perspectieven opleveren. Kurtom, het onderzoek is empirisch, historisch en sociologisch van aard en bovendien theorie gestuurd.

\section{Het euthanasiedebat als casus}

Voor de uitwerking van het onderzoek is gekozen voor het bestuderen van één casus; een case-study. Een case-study aanpak is te karakteriseren als een gedetailleerde of diepgaande studie van een (afgebakend) onderwerp. Het betreft empirisch onderzoek naar een specifieke kwestie of een fenomeen waarbij meerdere bronnen kunnen worden gebruikt (literatuuronderzoek, intervicws, observaties). ${ }^{6}$ Door de focus te richten op één verschijnsel of proces is het mogelijk om met name aandacht te besteden aan aspecten van verwevenheid en samenhang. Dit is belangrijk als een eerste verkenning van verschijnselen die niet bij voorbaat helder zijn; de dynamiek van de interacties staat centraal. Casestudies hebben primair een exploratief karakter. Een kritische kanttekening bij de aanpak van de case-study is de vraag of de verworven inzichten ook gelden voor andere situaties, met andere woorden: hebben de conclusies enige algemene geldigheid? Bij een case-study, in meer algemene zin bij kwalitatief onderzoek, vindt generalisatie plaats door abstractie. Het generaliseren heeft geen betrekking op populatie niveau, maar op verschijnselen of processen (Van der Veen 1990; Komter 1983).

Als casus is gekozen voor het professionele debat over levensbeëindigend handelen in Nederland in de periode 1960-1994. De onderzoeksperiode start rond het begin van de jaren zestig, omdat dan in Nederland het debat over de medisch-ethische consequenties van de nieuwe reanimatie- en transplantatietechnieken wordt geopend. Het onderzoek zelf is in 1997 van start gegaan. Op dat moment was de formalisering van de zorgvuldigheidseisen voor euthanasie, in het wetsontwerp van 1994 , een duidelijk cindpunt voor de onderzoeksperiode. De zorgvuldigheidseisen vormen namelijk de belichaming van ontwikkelingen in de normering en regulering van levensbeëindigend handelen. In de empirische hoofdstukken ligt her eindpunt van de onderzoeksperiode dan ook halverwege de jaren negentig. Een reflectie op meer recente ontwikkelingen ná deze periode - vanuit het theoretisch kader in dit boek - is in het laatste hoofdstuk te vinden. De keuze voor het professionele debat en niet bijvoorbeeld her politieke of publieke debat is gemaakt om de haalbaarheid en helderheid van het onderzoek te vergroten. Het gaat om het debat in kringen van degenen die zich professioneel met ethiek en recht in de context van de geneeskunde hebben beziggehouden.? 
Politieke en maatschappelijke ontwikkelingen komen in de context van het professionele debat aan de orde, maar zijn niet zelfstandig object van onderzoek. De keuze voor her debat over levensbeëindigend handelen is op grond van verschillende overwegingen gemaakt. Ten eerste is dit debat één van de eerste controversiële en prominente medisch-ethische debatten. Het onderwerp heeft sinds eind jaren zestig onafgebroken in de belangstelling gestaan en is dus in de termen van Crigger een 'classic'. Dat betekent dat er sinds die tijd een ruime hoeveelheid aan materiaal beschikbaar is. Ten tweede zijn in dit debat belangrijke ethische en juridische noties zoals zinvragen en zelfbeschikking aan de orde. Ten derde zijn er interessante verschuivingen geweest in de afbakening en nadere omschrijving van het onderwerp. Uit de empirische hoofdstukken wordt duidelijk dat het boek gaat over debarten die we het euthanasiedebat zijn gaan noemen, maar achter dit begrip gaan een normatieve betekenis en een strijd schuil. Deze hoofdstukken illustreren hoe lastig het is om over 'het' euthanasiedebat te spreken. Het concept 'euthanasie' heeft namelijk in de jaren zestig en zeventig verschillende invullingen gekend. Om die verschillen aan te duiden sprak men bijvoorbeeld over actieve, passieve, directe en indirecte euthanasie, totdat het begrip in de jaren tachtig scherp was afgebakend. In de jaren negentig stonden, met de introductie van het begrip 'medische beslissingen rond het levenseinde', weer meerdere zaken ter discussie zoals bijvoorbeeld levensbeëindiging zonder verzoek in geval van dementie. Deze bewegingen in de discussie gaan gepaard met en zijn het resultaat van domeinafbakening en conceptuele ontwikkelingen. Ten vierde hebben vooraanstaande ethici (Sporken, Kuitert, Dupuis) en juristen (Leenen, Legemaate) sterk geprofileerde posities ingenomen. Al deze overwegingen maken het debat over levensbeëindigend handelen tot een interessante casus.

Om een indruk te krijgen van het verloop van de discussie volgt in vogelvlucht een schets van het debat. In de jaren zestig en zeventig ging het debat voornamelijk over de vraag wat nu precies onder euthanasie moest worden verstaan en of levensbeëindigend handelen (moreel) zou moeten of kunnen worden toegestaan (Houtepen \& Kater 200I). Er leek overeenkomst te zijn wat betreft de constatering dat ontwikkelingen in de geneeskunde de arts voor nieuwe en moeilijk oplosbare dilemma's hadden geplaatst. Er waren vele nieuwe vragen en onzekerheden en het debat had dan ook een breed karakter. Halverwege de jaren tachtig werd er consensus bereikt over een eenduidige formulering van het begrip euthanasie. Het debat beperkte zich voornamelijk tot euthanasie en hulp bij zelfdoding, waarbij zelfbeschikking een centrale rol speelt. De andere 'vormen van euthanasie' werden vanaf die periode als normaal medisch handelen beschouwd. Over de juridische acceptatie ontstond ook duidelijkheid; euthanasie was weliswaar een strafbaar feit, maar de arts werd vrijgepleit door een beroep op overmacht. Dat beroep gold op voorwaarde dat aan de eisen 
van zorgvuldigheid was voldaan. In de jaren negentig kwam er een stroom aan kwantitatief en kwalitatief onderzoek naar de praktijk van levensbeëindigend handelen op gang. Daaruit werd mede duidelijk dat inmiddels met name het levensbeëindigend handelen zonder verzoek een probleem op zich was. Het debat over levensbeëindigend handelen zonder verzoek bleek niet afgesloten; dit thema stond in de jaren negentig weer volop op de agenda. Daarmee stond ook het concept van zelfbeschikking ter discussie. Dit leverde wederom een nieuw type discussie op. De vraag luidt nu hoe in dit debat de disciplines recht en ethiek zich hebben ontwikkeld.

\section{Vervolg van het boek}

Het volgende hoofdstuk behandelt de achtergrond van de probleemstelling. Daarbij komt het zelfbeeld van de disciplines recht en ethiek aan de orde, dat wil zeggen de interne verhalen en verklaringen over de eigen ontwikkeling. Hieruit wordt duidelijk dat die verhalen beperkt zijn. Bovendien wordt slechts in beperkte mate aandacht besteed aan de verhouding tussen de beide vakgebieden waardoor ze minder geschikt zijn om de onderzoeksvraag te beantwoorden. In hoofdstuk drie tot en met vijf wordt verslag gedaan van het empirisch onderzoek naar de ontwikkeling en verhouding van beide disciplines.

In hoofdstuk drie wordt een professiesociologische analyse beschreven van gezondheidsethiek en gezondheidsrecht, aan de hand van jurisdictieclaims. Het claimen van zeggenschap en het roebedelen en opeisen van diverse verantwoordelijkheden bij betrokken actoren in het eurhanasiedebat is onderzocht. Zeggenschap over medische ethiek en euthanasie is niet alleen een kwestie van afbakening van het eigen terrein, maar ook een strijd om competentie en het toekennen van verantwoordelijkheden.

Hoofdstuk vier betreft een sociaal-conceptuele analyse van de ontwikkeling in denkstijlen en paradigmata binnen de medische ethiek, met name van verschuivingen in de positie van de patiënt bij euthanasie. Aan de hand van de theoretische concepten 'paradigma' en 'denkstijl' zijn veranderingen in her denkkader van beide vakgebieden onderzocht. Hierbij wordt speciale aandacht besteed aan de huidige centrale positie van respect voor de autonomie en de zelfbeschikking van de patiënt. Dit gedeelde paradigma voor ethiek en recht vertoonde in het debat over wilsonbekwamen en levensbeëindigend handelen enkele barsten.

In hoofdstuk vijf is aan de hand van inzichten uir het recente wetenschapsonderzoek een netwerkanalyse verricht naar het tot stand komen van normering en regulering rond levensbeëindigend handelen. Dezc analyse biedt inzicht in de rol van recht en ethiek hierbij, alsmede de hoeveelheid werk die is verzer 
om tot een succesvol resultaat te komen. Het uitgangspunt is dat normatieve en juridische expertise het resultaat zijn van de manier waarop netwerken rond levensbeëindigend handelen zijn opgebouwd.

In hoofdstuk zes worden de conclusies uit het onderzoek gepresenteerd. Daarin worden recht en ethiek als een strijd om afbakening, conceptuele kaders en complexe netwerken gepresenteerd. Onderlinge verhoudingen lijken soms stabiel, maar zijn als gevolg van deze interactie en dynamiek wel degelijk aan veranderingen onderhevig. Elke orde die op een bepaald ogenblik bestaat is tijdelijk en relatief. De proto-juridisering van de ethiek is binnen dit beeld dan ook geen vast gegeven, maar moet als een specifieke en historisch gesitueerde invulling van het vakgebied worden opgevat. De heuristiek van de drievoudige analyse in het onderzoek wordr nader geillustreerd aan de hand van een actuele casus uit het Nederlandse euthanasiedebat; de zaak Brongersma. Wil deıt geruchtmakende zaak echt een wending in het debat betekenen, dan moet er nog heel wat gebeuren in termen van zeggenschap, strijd, denkstijlen en netwerken. Het hoofdstuk eindigt met een aanzer over de rol en betekenis van ethiek en recht in actuele en morele matschappelijke debatten. De vraag is of ethiek en rechr, zoals de kritiek soms luidt, altijd en onvermijdelijk achter de feiten aanlopen of dat er (ook) een andere rol voor recht en ethiek is weggelegd. 


\section{EEN KENNISMAKING MET RECHT EN ETHIEK IN DE GEZONDHEIDSZORG}

\section{'De ethiek verkent, het gezondheidsrecht herkent.'}

(Roscam Abbing \& Dillmann 1997)

De institutionalisering van recht en ethiek biedt een goede ingang om een eerste indruk te krijgen van de disciplines gezondheidsethiek en gezondheidsrecht. In dit hoofdstuk wordt ingegaan op de manier waarop recht en ethiek zijn verankerd in de universiteiten, het beleid en het veld. Er zal een aantal verschillen en overeenkomsten tussen beide vakgebieden worden geschetst. Ook ontmoetingsplaatsen zoals tijdschriften en verenigingen vormen een relevant gegeven voor het bestuderen van een vakgebied. Daar vinden uitwisseling van informatie en discussies over relevante onderwerpen plaats. De manier waarop deze ontmoetingsplaatsen zijn vormgegeven zegt iets over het vakgebied zelf. Dat geldt ook voor handboeken. Handboeken geven een idee welke kennis als relevant wordt beschouwd voor een discipline. In handboeken geven auteurs de stand van zaken weer die op dat moment als gangbaar en betrouwbaar geldt. Uit de institutionalisering kan worden afgeleid dat de twee disciplines niet meer weg te denken zijn uit het beleid, onderzoek en onderwijs op het terrein van de gezondheidszorg.

Het (historisch) zelfbeeld van recht en ethiek vormt een tweede aanknopingspunt om kennis te maken mer beide disciplines. Zelfbeelden gunnen een blik op de wijze waarop de betrokken actoren zelf tegen hun vakgebied aankijken. Ze bieden een overzicht over wat intern als belangrijke of inhoudelijk interessante of relevante gebeurtenissen worden beschouwd. Een terugblik op (het ontstaan van) een discipline of het schrijven van een disciplinegeschiedenis is veelal het werk van wetenschappers die in de betreffende discipline zijn opgeleid. Voor de beschrijving van deze zelfbeelden is uit monografieën en handboeken geput. In het kader van het zelfbeeld geven juristen en ethici soms ook hun visie op de verhouding tussen recht en ethiek. Deze relatie kan in verschillende termen worden aangeduid, bijvoorbeeld als een harmonieuze relatie, een haat-liefde verhouding, een competitieve, coöperatieve of complementaire relatie.

Het hoofdstuk is als volgt opgebouwd. In de tweede paragraaf kom de institutionalisering van beide disciplines aan de orde. De volgende twee paragrafen geven het zelfbeeld van respectievelijk het gezondheidsrecht en de gezondheids- 
ethiek weer. De daaropvolgende paragraaf behandelt verschillende claims over de verhouding tussen recht en ethiek zoals die over de twee disciplines zijn geformuleerd. De laatste paragraaf gaat in op de beperkingen van het gebruik van zelfbeelden voor onderzoek naar de verhouding en ontwikkeling van disciplines. Deze paragraaf vormt de overgang tussen dit hoofdstuk en het gedeelte waarin verslag wordt gedaan van het empirisch onderzoek, namelijk hoofdstuk drie, vier en vijf.

\section{Twee normatieve vakgebieden}

\section{Institutionalisering van ethiek en recht}

Bij een kennismaking, in welke situatie dan ook, valt meteen een aantal zaken in het oog. Pas in tweede of derde instantie volgt een meer diepgaande analyse. Op dezelfde manier kan een kennismaking met een discipline worden gearrangeerd. De vraag is dan, wat er 'op het eerste gezicht' opvalt aan de disciplines gezondheidsethiek en gezondheidsrecht. Waar vinden onderzoek en onderwijs plaats? In welke tijdschriften wordt gepubliceerd? Bij welke verenigingen ontmoeten vakgenoten elkaar? Is het vakgebied relatief homogeen of is sprake van grote diversiteit? Aan de hand van dit type vragen wordt in deze paragraaf de institutionalisering van recht en ethiek beschreven.

De verankering van recht en ethiek heeft bij diverse vakgroepen en in het onderwijs aan universiteiten vorm gekregen. ${ }^{\prime}$ De namen van de verschillende vakgroepen variëren van gezondheidsethiek tot metamedica, gezondheidsrecht en sociale geneeskunde. Naar de plaats van de ethiek en het recht in het medisch onderwijs is begin jaren negentig onderzoek gedaan. Dit onderzoek was gericht op de feitelijke en gewenste inbreng van de beide vakgebieden in de medische opleiding (Ten Have \& Van Wijmen et al. 1994; Van Wijmen \& Ten Have et al. 1994). Het belang van de bijdrage van ethiek en recht aan de opleiding geneeskunde werd door de betrokkenen wel onderschreven. Maar de onderzoekers concludeerden dat er dringend maatregelen nodig waren om het onderwijs in ethiek en recht uit te breiden en te verbeteren.

$\mathrm{Bij}$ de verschillende centra op het terrein van gezondheidserhiek en gezondheidsrecht vormt onderwijs slechts één aspect van het takenpakket: de aandacht gaat primair uit naar onderzoek. Deze centra zijn soms gelieerd aan de universiteit, maar verwerven hun fondsen meestal buiten de universiteit. De centra kunnen dus als een verankering in het veld van de gezondheidszorg worden gezien, met name van de ethiek en in mindere mate van het recht. De adviezen die worden gegeven op basis van onderzoek zijn bedoeld voor de overheid en andere beleidsmakers op her gebied van de gezondheidszorg. Er zijn in Nederland drie 
onderzoekscentra opgericht, te beginnen in 1984 met het Instituut voor Gezondheidsethiek (IGE) in Maastricht. Eind jaren zeventig was een aantal mensen uit de ethiek, gezondheidszorg en overheid bij elkaar gekomen met de bedoeling om een instituut voor ethiek op het terrein van de gezondheidszorg op te richten. Dit concept was overgenomen van initiatieven in de Verenigde Staten; het Hastings Center en het Kennedy Center. Het was de bedoeling dat in het op te richten instituut een systematische bezinning over ethische vragen in en rond de gezondheidszorg zou plaatsvinden. Het zou een onafhankelijk instituut moeten zijn met ruimte voor verschillende levensbeschouwingen (IGE 1986: 10).

Het tweede onderzoekscentrum, in 1987 in Utrecht opgericht, is het Centrum voor Bio-ethiek en Gezondheidsrecht (CBG). Het CBG is het enige onderzoekscentrum waar onderzoek naar ethiek en recht verenigd is. Het CBG is een interdisciplinair samenwerkingsverband van verschillende faculteiten van de Universiteit Utrecht en de Katholieke Theologische Universiteit. Het CBG is opgericht vanuit het idee dat er sinds halverwege de jaren tachtig steeds meer behoefte leek te bestaan aan ethische en juridische advisering in de gezondheidszorg. 'Opvallend was, dat de ethische en gezondheidsrechtelijke vragen vaak in elkaars verlengde lagen' (CBG 1988). De naam bio-ethiek geeft aan dat men van een bredere invulling van het begrip ethiek uitgaat: gezondheid en welzijn van mens en dier. Men gaat er van uit dat de prakrijk van bio-ethiek en gezondheidsrecht zich niet beperkt tot ziekenhuizen en zorginstellingen. Daarom vallen bijvoorbeeld ook farmaceutische bedrijven en de voedingsmiddelenindustrie binnen het aandachtsgebied.

Bij het derde onderzoekscentrum, het CEKUN (Centrum voor Ethiek Katholieke Universiteit Nijmegen, opgericht in 1993), wil men in tegenstelling tor het IGE en het CBG géén direcre maar meer een indirecre bijdrage leveren aan de toegepaste ethiek. Men beoogt juist de fundamentele problemen die met deze toegepaste ethiek gepaard gaan te onderzoeken. Het doel van het CEKUN is zowel het verrichten van onderzoek als het verzorgen van onderwijs vanuit een wijsgerig en theologisch perspectief (Zwart 1993a: II2). De aandacht gaat uit naar het maken van analyses van de manier waarop toegepast-ethische vragen worden gesteld, uitgewerkt en beantwoord; ofwel om een brede oriëntatie van de ethiek (p. II2). De oprichting van het CEKUN is daarmee op te vatten als een kritische reactie op de gangbare wijze van ethiekbeoefening. De eigen ethiekopvatting is ingevuld als een hermeneutische benadering van ethiek (CEKUN 1999: 6). Hiermee werd beoogd om, in plaats van de ethische complexiteit te reduceren, de complexiteit van de probleemsituatie vast te houden en ter sprake te brengen. Het CEKUN is dus ontstaan vanuit de behoefte aan een andere ethiekopvatring.

Niet alleen uit het onderwijs en onderzoek bij universiteiten of bij aan de universiteit gelieerde onderzoekscentra valt af te leiden dat gezondheidsrecht en g'zondheidsethiek in Nederland geïnstitutionaliseerd zijn. Ook de vele com- 
missies die er op dit gebied zijn, vormen een aanwijzing dat recht en ethiek stevig geworteld zijn in de maatschappij. De Beraadsgroep Gezondheidsethiek en Gezondheidsrecht, een permanente commissie van de Gezondheidsraad, heeft een relatief lange geschiedenis. Deze commissie is in 1977 opgericht. Eén van de raken van de Bcraadsgroep is het beoordelen van adviezen geschreven door ad-hoc commissies in opdracht van regering en parlement. Soms schrijft de Beraadsgroep ook zelf een advies. In de commissie zitten experts op het terrein van de gezondheidsethiek, het gezondheidsrecht en de geneeskunde. De te beoordelen adviezen gaan over uiteenlopende onderwerpen, zoals genetische screening, voortplantingstechnologie en xeno-transplantatie. De Beraadsgroep heeft niet alleen een adviesfunctie, maar functioneert ook als een netwerk of ontmoetingsplaats voor ethici en juristen (Leenen 1994b: 86).

Een tweede voorbeeld van een ontmoetingsplaats tussen juristen en ethici vormen de diverse medisch-ethische commissies. Per I december 1999 zijn bijvoorbeeld alle instellingen waar wetenschappelijk onderzoek met mensen plaatsvindt, volgens de Wet Medisch-wetenschappelijk Onderzoek met mensen (WMO) verplicht om een medisch-ethische commissie te hebben die het betreffende onderzoek toetst. Dat betekent dat het nu wettelijk verplicht is om voorafgaand aan de start van een onderzoek met mensen een positief oordeel te hebben verkregen van een erkende medisch-ethische toetsingscommissie. In deze commissie zitten standaard een jurist en een ethicus. Dat is geen nieuw gegeven, want in de praktijk gold dit al vanaf midden jaren tachtig. Veel van de toen opgerichte commissies gingen zich ook met klinisch-ethische vragen bezighouden; ethische commissies binnen ziekenhuizen bijvoorbeeld die met diverse casus werkten en protocollen opstelden. Ook in de Centrale Commissie Medisch Onderzoek (ссмо), die landelijk toezicht houdt op de uitvoering van de wMo, zijn zowel juristen als ethici vertegenwoordigd.

Een derde voorbeeld van de institutionalisering van recht en ethiek in de vorm van commissies, zijn de (vijf) regionale toetsingscommissies voor euthanasie. Sinds I november 1998 beoordelen deze commissies, bestaande uit een jurist (voorzitter), ethicus en een arts, achteraf of een arts bij euthanasie of hulp bij zelfdoding zorgvuldig heeft gehandeld. Is de toetsingscommissie van oordeel dat een arts zorgvuldig heeft gehandeld, dan geldt dat voor het Openbaar Ministerie als een zwaarwegend advies om niet tot vervolging van de betreffende arts over te gaan.

\section{Handboeken, verenigingen en tijdschriften}

Handboeken geven de stand van zaken op een bepaald moment in een vakgebied weer. Daarmee genieten ze een zekere status. Kennis en informatie in een handboek worden als duurzamer beschouwd dan die in artikelen. Zeker als een 
handboek meerdere herdrukken kent. Bij het gezondheidsrecht was er tot voor kort één auteur van de handboeken: de thans emeritus hoogleraar gezondheidsrecht Leenen. Het eerste handboek dateert van 1978 en in 2000 verscheen de vierde druk van het handboek gezondheidsrecht, dat inmiddels door Leenen en Gevers (hoogleraar gezondheidsrecht) samen is bewerkt (Leenen 1978; Leenen 2000a). ${ }^{2}$ Over een periode van ruim twintig jaar is voor het gezondheidsrecht het handboek in handen geweest van één auteur. Deze handboeken gelden allemaal als standaardwerken op het terrein van het gezondheidsrecht, zoals uit recensies over het handboek blijkt (Van Wijmen 1996). Uit de diverse herdrukken van het handboek, de verschillende recensies en de vele literatuurverwijzingen blijkt dat Leenen een uitstekende reputatie geniet met betrekking tot zijn handboek(en).

In de handboeken staat dat het een taak van het gezondheidsrecht is om, binnen de context van maatschappelijke ontwikkelingen, aandacht te besteden aan de zelfbeschikking van de mens (Leenen 1978: 9; Leenen 2000a: Ir). Door ontwikkelingen in de wetenschap en de technologie, zou de gezondheidszorg een steeds ingrijpender karakrer hebben gekregen. Met name de afhankelijkheidspositie van de patiënt vormt in dit palet van ontwikkelingen een belangrijk aandachtspunt. Het recht wil zich dus, als wetenschappelijke discipline, opstellen ten dienste van de patiënt. Als doelstelling worden genoemd de bescherming van de patiënt en het regelen van verhoudingen, bijvoorbeeld tussen arts en patiënt.

Deze dienstbaarheid is ook terug te vinden in een deel van de handboeken, monografieën over en inleidingen in gezondheidsechiek. In tegenstelling tor het recht zijn deze boeken echter in de loop der tijd door diverse auteurs geschreven. Bij de gezondheidsethiek is geen sprake van één aureur die als 'pater familias' fungeerde en die over een lange(re) periode het monopolie heeft (gehad) over het schrijven van handboeken. Dit maakt het lastiger om één bepaald boek aan te duiden als het eerste handboek.

De twee boeken Recent Medisch Ethisch Denken deel I en 2 kunnen als overgangswerken in de medische ethiek worden beschouwd (Kortbeek 1968; Hermans 1970). Er was, vanwege her grote enthousiasme voor het plan om een monografie over ethiek uit te geven, besloten dat het niet één maar twee delen zouden worden. In de inleiding tot het tweede deel werden de veranderingen in de ethiek benadrukt om het verschijnen van een tweede deel te legitimeren. De redactie vond het belangrijk dat in een periode, waarin het medisch-ethisch handelen zoveel van zijn deels sterk verouderde, aan taboes en dogma's gebonden achtergronden heeft verloren, de gedachten en meningen van een aantal vooraanstaande auteurs samen te brengen, vooral ook omdat nog heftig wordt gestreden om een aanvaardbare, op een acceptabele basis uitgroeiende nieuwe vorm van ethiek' (p. 5). Tot 1968 waren het alleen artsen die hierover schreven 
zoals het zogenoemde 'Blauwe boekje' van de KNMG. Het Blauwe boekje bevatte gedragscodes voor artsen en was ook geschreven door artsen (KNMG 1959). In de twee delen van Recent Medisch Ethisch Denken staan, naast bijdragen van artsen, ook bijdragen van een ethicus en jurist.

In recentere uitgaven van handboeken ethiek zijn de bijdragen van anderen dan artsen alleen maar toegenomen. Het meest in het oog springende voorbeeld van een groot aantal verschillende bijdragen is wel het Handboek Gezondheidsethiek onder redactie van de ethici De Beaufort en Dupuis (De Beaufort \& Dupuis 1988). Het boek is een verzameling hoofdstukken van de hand van bijna 40 (!) auteurs. Volgens de redacteurs was deze multidisciplinaire aanpak nodig. Deze aanpak kwam namelijk 'overeen met de dagelijkse werkelijkheid van de gezondheidszorg, waarin immers ook verschillende beroepsgroepen met tal van morele vragen worden geconfronteerd, en vaak een eigen inbreng hebben bij de beantwoording ervan' (p. r). Deze auteurs hadden niet allemaal een theologische of filosofische achtergrond. Sommigen waren bijvoorbeeld werkzaam op het terrein van de geneeskunde, het recht of de psychologie. Een blik in verschillende inleidingen (gezondheids)ethiek leert dat de opzet van de handboeken gezondheidsethiek een meer diffuus beeld oplevert dan bij het gezondheidsrecht, bijvoorbeeld: Voorlopige Diagnose en Ethiek en Gezondheidszorg (Sporken 1969b, 1977), Voordelen van de twijfel (Dupuis \& Thung 1983) en Medische ethiek (Ten Have \& Ter Meulen er al. 1998). Deze boeken zijn, in vergelijking mer de handboeken gezondheidsrecht, minder duidelijk als handboek te karakteriseren. Er is nier één kenmerkende opzet voor deze boeken te geven.

Het Handboek Gezondheidsethiek uit 1988 was bedoeld om het denken over en omgaan met ontwikkelingen in de gezondheidszorg te structureren en verhelderen. Het zou zowel inzicht moeten geven in de morele problemen van de gezondheidszorg alsook een handreiking moeten bieden voor de oplossing ervan. Hoewel expliciet werd gesteld dat het niet om kant-en-klare oplossingen ging, werden er soms toch concrete aanbevelingen gedaan (De Beaufort \& Dupuis r988: 2). De doelstelling om mensen aan her denken te zetten of bouwstenen aan te leveren voor een standpuntbepaling over morele problematiek in de gezondheidszorg, is in meer boeken over medische ethiek te vinden De uitwerking loopt echter uiteen van het aanreiken van begrippen, het neerzetten van een kritisch perspectief tot het aanbieden van een oplossingsgerichte opzet. ${ }^{3}$ Een oplossingsgerichte aanpak (ten dienste van de arts) is bijvoorbeeld te vinden in het op casuïstiek gerichte boek Wat zou u doen?'Hoe vaak komen de beschreven problemen voor? Wij weten het niet, maar zijn ervan overtuigd dat artsen mer regelmaat in soortgelijke ingewikkeld en precaire situaties terechtkomen. De vraag is dan steeds: wat te doen? Voor allen die zich hierop willen bezinnen is dit boek geschreven. Wij denken daarbij vooral aan artsen en aanstaande artsen, van elk specialisme, met enige nadruk op de huisarts' (p. 9). Dit 
boek vertrekt vanuit het idee dat in inleidingen en handboeken medische ethiek wel veel over medisch-ethische problemen en de bijbehorende morele en juridische denkwijzen staat te lezen, maar dat er weinig concrete casuïsriek voorhanden is. Om hieraan tegemoet te komen worden diverse casus aangeboden die met behulp van een ethisch stappenplan 'opgelost' zouden kunnen worden. ${ }^{4}$ Dit ethisch stappenplan wordt als een standaardaanpak van medisch-ethische dilemma's gepresenteerd (Dupuis \& De Beaufort et al. 1994: 11). Kortom, bij de handboeken en inleidingen medische ethiek is er sprake van verschillende ideeën over de 'dienstbaarheid' van het vakgebied ten opzichte van de medische praktijk. Enerzijds wordt dit ingevuld als het aanreiken van concepten om beter analyses te kunnen maken van ontwikkelingen in de gezondheidszorg. Anderzijds zou de dienstbaarheid bestaan uit het aanbieden van standaard oplossingsstructuren voor diverse medisch-ethische problemen in de praktijk.

Niet alleen handboeken zijn een manier om zich te profileren. Ook ontmoetingsplaatsen zoals verenigingen en tijdschriften kunnen hieraan bijdragen (Leenen 200ob). De geschiedenis van het recht gaat wat dit betreft verder terug dan die van de ethiek. In 1967 werd het eerste wereldcongres voor medisch recht in Gent gehouden. Op dit congres was ook een delegatie uit Nederland aanwezig. De jurist Leenen heeft na afloop van dit congres aan deze groep deelnemers een brief gestuurd met het voorstel om een vereniging voor gezondheidsrecht op te richten. Een eerste bijeenkomst was niet lang daarna gepland (Leenen 1978). Uit deze groeiende contacten is volgens Leenen de oprichting van de Werkgroep Gezondheidsrecht in 1967 ontstaan, mede vanwege de behoefte om over het vak te publiceren (Leenen 1993). Deze werkgroep heeft een jaar later tot het ontstaan van de Vereniging voor Gezondheidsrecht geleid. Leden van deze vereniging zouden in eerste instantie juristen moeten zijn, maar er werd de mogelijkheid opengelaten om ook niet-juristen toe te laten treden (bijvoorbeeld als buitengewoon lid) (Leenen 1992c: 130).

Het idee werd geopperd om middels het houden van voordrachten, en later het schrijven van preadviezen, van gedachten te wisselen over diverse onderwerpen.' Daarnaast werden er werkgroepen ingesteld, eveneens om de studie van het gezondheidsrecht te bevorderen. Hoewel aanvankelijk aan een ledental van rond de 50 werd gedacht, waren dit er in het jaar 2000 ongeveer 800 . De mogelijkheden om te publiceren over het vak werden groter met de oprichting van het Tijdschrift voor Gezondheidsrecht in december 1975 .

Vergeleken met het gezondheidsrecht werd bij de ethiek pas later actie ondernomen tor het oprichten van een vereniging. Maar er waren al wel tijdschriften waarin ethici zich vanaf de jaren zestig in profileerden, waaronder het protestantse artsenblad Soteria en later Metamedica, (een voortzetring van het Katholieke Artsenblad). Begin jaren negentig is Metamedica overgegaan in het Tijdschrift voor Geneeskunde en Ethiek. In die periode is ook actie ondernomen 
voor het oprichten van een vereniging. In juli 1993 werd de Nederlandse Vereniging voor Bio-ethiek (NVBE) opgericht. Bio-ethiek werd omschreven als een systematische reflectie op morele vragen waartoe - nieuwe - ontwikkelingen in de levenswetenschappen aanleiding gaven. Een 'jong wetenschapsgebied', waar diverse disciplines bij elkaar kwamen: biologie, ecologie, (dier)geneeskunde, ethiek, recht, filosofie en sociologie (NVBE 2000). Het lidmaatschap van de vereniging werd opengesteld voor eenieder die zich vakinhoudelijk bij bioethische vraagstukken betrokken voelde. Het doel van de vereniging was onder andere contacten tussen vertegenwoordigers uit verschillende disciplines, betrokken bij bio-ethische kwesties, te bevorderen. Middels het uitgeven van een nieuwsbrief werd dit doel ondersteund. Net als bij de Vereniging voor Gezondheidsrecht wordt ook bij de NVBE een systeem van het schrijven van preadviezen gehanteerd. Deze studies vormen bij elke jaarvergadering aanleiding voor discussie tijdens het wetenschappelijk gedeelte. Een aantal van de leden van de NVBE was/is lid van de al oudere Vereniging voor Filosofie en Geneeskunde (VFG). Dit zou een reden kunnen zijn voor de 'late' oprichting van de NVBE. De VFG richt zich niet alleen op medische ethiek. ${ }^{6}$

De institutionalisering van recht en ethiek is sinds de jaren zeventig in gang gezet. Het onderwijs, onderzoek en advieswerk binnen beide disciplines hebben een plek verworven in de maatschappij. Op het eerste gezicht is de gezondheidsethiek, in diverse opzichten, een meer divers vakgebied dan het gezondheidsrecht. Bij de ethiek hebben meer disciplines een aandeel in de ontwikkeling van het vakgebied. De relatieve homogeniteir van het recht kan waarschijnlijk voor een deel op het conto van Leenen worden geschreven. Leenen is in ons land de initiator van en motor achter het ontwikkelen van een (sociaal) netwerk voor het ontplooien van activiteiten op het terrein van het gezondheidsrecht geweest. De volgende paragraaf zal dit beeld nog meer ondersteunen.

\section{Gezondheidsrecht}

\section{Medisch recht, sociaal-hygiënisch recht en gezondheidsrecht}

In de meest recente uitgave van het handboek gezondheidsrecht wordt het vakgebied omschreven als 'het geheel van rechrsregels dat betrekking heeft op de zorg voor de gezondheid en de toepassing van overig burgerlijk, bestuurs- en strafrecht in dat verband' (Leenen 2000a: 19). 'Aan deze benaming van het vakgebied is enige discussie voorafgegaan. Er was aanvankelijk verschil van mening over de reikwijdte, invulling en de daaraan gerelateerde benaming van het vakgebied. De discussie werd afgesloten met de oprichting van de Vereniging voor Gezondheidsrecht. Voorstanders van andere benamingen legden zich toen neer 
bij de term gezondheidsrecht. Voordat op de naamgeving voor het (toekomstige) vakgebied wordt ingegaan, volgen eerst de motieven voor het waarom van en de noodzaak tot een discipline gezondheidsrecht.

In de jaren vijftig zouden er verschillende aanwijzingen zijn voor de behoefte aan een specialisme van het recht op het terrein van de gezondheidszorg (Leenen 1978). Ten eerste wees Leenen op een preadvies uit 1954, geschreven door de 'nestor' van het gezondheidsrecht, de jurist Goudsmit. Deze zou als eerste de wetenschappelijke discussie over gezondheidsrecht op gang hebben gebracht. ${ }^{8}$ Het pleidooi van Goudsmit was gericht op een nieuw type juristen. Deze zouden kennis en belangstelling moeten hebben voor zowel algemene rechtsbeginselen als ontwikkelingen in de gezondheidszorg. Zijn uitgangspunten voor het nieuwe vakgebied zijn later bekritiseerd als te 'breed', onder andere omdat bijvoorbeeld ook de 'hygiënische eisen' die aan woningen gesteld werden onder deze omschrijving zouden kunnen vallen (Leenen 1968; Rang 1974). Ten tweede wees Leenen op het vire Internationale Congres van Katholieke Artsen, dat in 1956 werd gehouden. Dit congres was mede georganiseerd door Leenen. In de slotrede werd een pleidooi gehouden voor het ontwikkelen van medisch recht, er werd echter geen omschrijving gegeven van het medisch recht. ${ }^{9}$ Ten derde zou er ook in de literatuur steeds meer animo zijn voor het gezondheidsrecht als specifiek onderdeel van het recht. Zo maakte de hoogleraar arbeidsrecht Van de Ven bij zijn indeling van sociale grondrechten ook een categorie van 'rechten betreffende de lichamelijke en geestelijke volksgezondheid (sociaal-hygiënische rechten)' (Van de Ven 1957: 38). Hij meende dat de rechten op gezondheidsgebied een voldoende eigen karakter hadden om als afzonderlijke rubriek te vermelden. Dit betekende echter niet dat hij daar ook het concept van een (nieuwe) discipline aan verbond. De strekking van zijn indeling impliceert wel dat de rechren op het terrein van de gezondheidszorg zijns inziens betrekking hadden op zowel de curatieve zorg, de preventieve zorg als de hygiëne in de brede zin van het woord, vandaar de brede benaming: sociaal-hygiënische rechten.

Mertens en Stolte, hoogleraren sociale geneeskunde uit Nijmegen, hielden eveneens een pleidooi voor een verdere ontwikkeling van het universitaire onderwijs in wat zij aanduidden als 'het medisch recht'. Hoewel ze aangaven dat er ook van 'gezondheidsrecht' of van 'sociaal-hygiënisch recht' gesproken zou kunnen worden, hanteerden ze toch voornamelijk de term 'medisch recht' (Mertens \& Stolte 1958: 218). Bij hun invulling van het 'medisch recht' stond vooral de arts centraal. Hun uitgangspunt was dat de arts goed geïnformecrd zou moeten zijn over de stand van zaken rond het recht in de gezondheidszorg. Ze stelden dat artsen in hun werk steeds meer met rechtsverhoudingen te maken kregen. Door de toenemende maatschappelijke inmenging mer de gezondheidszorg zou het medisch recht steeds meer in betekenis toenemen (p. 2ro)). 
In 1965 benadrukte Mertens nogmaals dat het van groot belang was dat het 'medisch recht' ook als vak zou worden opgenomen in het curriculum van geneeskunde studenten (Mertens 1965). Het zwaartepunt van het medisch recht werd door Mertens en Stolte bij het bestuursrecht gelegd, méér dan op het terrein van het burgerlijk recht of het strafrecht. Dat wil zeggen dat noch de arts-patiëntrelatie, noch de strafrechtelijke aansprakelijkheid van de arts door hen als de meest interessante gebieden voor het medisch recht werden beschouwd. Volgens hen zouden juist de regelingen en voorzieningen van bijvoorbeeld het ziekenfondswezen en de sociale verzekeringen, alsmede de bedrijfskunde een aandachtsgebied zijn van het medisch recht (p. 220). Daarmee hadden ze aangegeven wat volgens hen het belang was voor de ontwikkeling van het medisch recht, voor zowel artsen als andere medewerkers in de geneeskunde. De invulling die Mertens en Stolte aan het medisch recht gaven, wijkt overigens af van het huidige werkterrein van het gezondheidsrecht. De arts-patiëntrelatie die volgens hen buiten de regelingen van het medisch recht zou moeten blijven is bijvoorbeeld het centrale onderwerp geworden in het (huidige) gezondheidsrecht.

Kortom, het was aanvankelijk niet duidelijk of het vak een plek zou weten te veroveren, hoe het eruit zou moeten zien en welke naam daaraan gegeven moest worden. Hierover heersten tegenstrijdige ideeën. De verschillende aanduidingen voor het nieuwe vakgebied laten zien dat er een begrippenstrijd heeft gewoed over de benaming van de discipline (in wording). Met name de termen medisch recht en gezondheidsrecht zijn serieus onderwerp van discussie geweest. De hoogleraar gezondheidsrecht Rang was altijd voorstander geweest van de term 'medisch rechr'. Dit zou meer overeenstemmen met de door hem voorgestane brede inzet van het vakgebied: het geheel van juridische maatregelen en instellingen inzake ziekte en gezondheid van de mens. Leenen had hiertegen bezwaar. Hij vond dat er bij deze omschrijving een te groot gebied onder zou vallen. Zo zouden bijvoorbeeld ook de Arbeidswet en de Grondwaterwet waterleidingsbedrijven onder deze omschrijving vallen (Rang 1974: 8). De discussie over het begrip is beëindigd door de oprichting van de Vereniging voor Gezondheidsrecht in I968. Volgens Rang had het na de oprichting van de vereniging geen zin meer om nog langer met de polemiek door te gaan, omdat het begrip gezondheidsrecht algemeen ingang had gevonden (Rang 1974: 15).

\section{Groei en ontwikkeling van het gezondheidsrecht}

Hoewel de ontwikkeling van het gezondheidsrecht eind jaren zeventig een succes kon worden genoemd, signaleerde Leenen toch ook een aantal knclpunten (Leenen 1979: I15). Leenen, de 'vader' van her gezondheidsrecht in Nederland, is tevens de grootste producent van terugblikken of arrikelen over de stand van 
zaken in het gezondheidsrecht. ${ }^{\circ}$ Volgens hem werd de groei van het recht op een gegeven moment belemmerd doordat er onvoldoende faciliteiten en middelen beschikbaar waren aan de universiteiten. "Leenen sprak de diverse juridische en medische faculteiten aan op hun verantwoordelijkheden hierin. Ondertussen waren er wel enkele leerstoelen op het gebied van het gezondheidsrecht in-gesteld. In 1970 was aan de Universiteit van Amsterdam het gezondheidsrecht voor het eerst in een leeropdracht opgenomen. ${ }^{12} \mathrm{Bij}$ het aanvaarden van zijn leerstoel sociale geneeskunde stelde Leenen namelijk voor om ook het gezondheidsrecht in de leeropdracht op te nemen. Dat voorstel werd positief ontvangen (Leenen 200ob: 25). ${ }^{13}$

De groei en ontwikkeling van het gezondheidsrecht verliep niet altijd naar ieders wens en ook de grondslagen van het gezondheidsrecht stonden op een gegeven moment ter discussie. In de jaren tachtig werd het idee dat er grondslagen zouden zijn voor het gezondheidsrecht aangevochten door Sluyters, in zijn oratie bij de aanvaarding van het ambt van bijzonder hoogleraar in het gezondheidsrecht in Leiden (Sluyters 1989). Sluyters deed daarmee een aanval op de door Leenen en anderen gesteunde idee dat het recht op gezondheidszorg en het zelfbeschikkingsrecht de twee grondslagen zouden vormen voor het gezondheidsrecht. ${ }^{14} \mathrm{Hij}$ meende juist dat er geen voor het hele gezondheidsrecht geldende beginselen en grondslagen waren. Het gezondheidsrecht was volgens hem een geheel van rechtsregels en zou dat ook moeten blijven. 'Wat zijn dan die grondslagen en beginselen van het gezondheidsrecht? Ik geloof dat die schitteren door afwezigheid. Het gezondheidsrecht is een conglomeraat van rechtsregels van zeer verschillende oorsprong. Ik noem voorbeelden: uit het strafrecht: euthanasie en dood door schuld, (...) uit het civiel recht: de relatie arts-patiënt, uir het administratief recht: de plannings- en de beroepenwetgeving. (...) Het is essentieel dat de verschillende onderdelen van het gezondheidsrecht geknipr verbonden zijn met het rechtsgebied waar zij ook toe horen: het strafrecht; het rechtspersonenrecht, etc. Zij moeten daarin ingebed blijven' (Sluyters 1985: 23). Deze opvatting van Sluyters is echter één van de weinige tegengeluiden die binnen het gezondheidsrecht te horen zijn. Zijn tegengeluid heeft wel tot een korte discussie tussen Leenen en Sluyters in het Tijdschrift voor Gezondheidsrecht geleid (Sluyters 1989; Leenen 1989b). Kortom, hoewel voor de grondslagen van de discipline geen strikte consensus geldt, lijkt er in het algemeen wel onderling overeenstemming te bestaan over de manier van werken.

Eén van de kernpunten van het gezondheidsrecht is dat wordt geprobeerd in te spelen op ontwikkelingen in de gezondheidszorg en maatschappij. Leenen claimt dat gezondheidsjuristen hier beter in zijn (geweest) dan ethici. Soms probeerden ethici in zijn ogen opnieuw het wiel uit te vinden als ze een onderwerp oppakten, terwijl er in het gezondheidsrecht al publicaties over voorhanden waren (Leenen 20oob: 74). Hij noemt enkele voorbeelden: het patiëntenrecht, 
de Wet op de Geneeskundige Behandelingsovereenkomst (wGBo) en de aanstellings- en verzekeringskeuringen. Terwijl juristen zich intensief met de wettelijke regulering hiervan bezighielden, zouden ethici pas in een laat stadium hun licht erover hebben laten schijnen of zelfs pas achteraf met kritiek zijn gekomen. Leenen meent dat dit te maken kan hebben met een verschil in atritude tussen ethici en juristen; juristen zouden in het algemeen meer dan ethici de behoefte hebben gehad om gewenste maatschappelijke veranderingen daadwerkelijk voor elkaar te krijgen (p. 75). ${ }^{\text {is }}$

Het is duidelijk dat er één centrale figuur is als een spin in het web: Leenen. Ten eerste zijn de initiatieven voor het oprichten van een vereniging en een tijdschrift van hem afkomstig. Ten tweede is het gros van de handboeken van zijn hand. Ten derde is een groot deel van de historische terugblikken van zijn hand. Ten vierde is de strijd rond de benaming van het vakgebied uiteindelijk (mede) in zijn voordeel beslecht. In Nederland wordt niet meer over medisch recht gesproken. De term gezondheidsrecht heeft algemeen ingang gevonden. Bovendien vertoont de invulling van het vakgebied grote gelijkenissen met zijn allereerste uitgangspunten. Tenslotte is het ook aannemelijk dat zijn invloed zich verder heeft laren gelden door de promovendi die hij heeft opgeleid. Ten minste negen van zijn promovendi zijn hoogleraar geworden op het terrein van het gezondheidsrecht dan wel de sociale geneeskunde (Leenen 200ob: 38). Op die manier is er een netwerk rond Leenen tot stand gekomen. Her gezondheidsrecht is dus op her eerste gezicht, mede dankzij de inspanningen van één man, een relatief homogeen vakgebied.

\section{Gezondheidsethiek}

\section{Medische ethiek, ethiek van de gezondheidszorg, gezondheidsethiek en bio-ethiek}

Binnen de gezondheidsethiek is er niet, zoals bij het gezondheidsrecht, één centrale figuur aan te wijzen die vanaf het begin op alle fronten (onderzoek, onderwijs, tijdschrift, vereniging) actief is geweest. Dat is een in het oog springend verschil als beide disciplines in een vogelvlucht terug in de tijd worden bekeken. Meerdere mensen hebben op eigen wijze getracht een bijdrage te leveren aan de ethiek. Dat blijkt niet alleen uir de handboeken, maar ook uit de kritische geluiden die er in de jaren tachtig klonken over het vakgebied. De voortdurende, deels onderhuidse, polemiek illustreert de reflexieve houding van ethici ten opzichte van hun vakgebied.

Sporken was de eerste hoogleraar medische ethiek. Hij was in 1974 aangesteld bij de faculteit geneeskunde van de toenmalige Rijksuniversiteit Limburg te Maastricht. Eind jaren zestig schreef hij een inleiding in de medische ethiek 
getireld Voorlopige diagnose. Hij gaf zijn boek deze titel mee, omdat hij het een onmogelijke taak vond om in die periode een inleiding in de medische ethiek te schrijven. Op dat moment was er volgens hem sprake van een snelle evolutie in de medische ethiek. Er waren zoveel veranderingen gaande dat het feitelijk onmogelijk was om er één ethische visie uit te destilleren. Vandaar dat het wat hem betreft om een 'diagnose' ging, waarbij de door hem gepresenteerde ethische visies een 'voorlopig' karakter droegen (Sporken 1969b).

Eind jaren zeventig waren de ontwikkelingen in de medische ethiek kennelijk beter te overzien. Sporken reflecteerde op deze ontwikkelingen in zijn boek Ethiek en gezondheidszorg (1977). Hij schetste de evolutie in de medische ethiek als een ontwikkeling van medische beroepscodes (gedragsregels inzake her handelen van de arts ten aanzien van patiënten en collega's) naar een medische beroepsethiek (met meer nadruk op de ethische normen met betrekking tot het uitoefenen van de geneeskunst). Vervolgens zou zich hieruit een medische ethiek hebben ontwikkeld mer een meer sociaal karakter (Sporken 1977: 56). Sporken had een verbreding van de ethiek voor ogen, in de zin van een meer antropologische invulling ervan. Daarom leek hem de term 'ethiek van de gezondheidszorg' ook meer geschikt dan de benaming medische ethiek. ${ }^{16}$ Hij was van mening dat ethiek niet meer iers van de individuele arts kon zijn, maar dat er een schaalvergroting in de ethiek moest plaatsvinden.

Het thema van een verbreding van de ethiek is bij meerdere ethici aan te treffen. Het wordt echter wel steeds anders gepresenteerd. Ondermeer door Dupuis, die sinds 1986 hoogleraar medische ethiek is te Leiden. In het Handboek gezondheidsethiek stelde Dupuis dat de reflectie op normen, waarden, plichten en rechten in de gezondheidszorg 'bij voorkeur niet meer medische ethiek [wordt] genoemd, maar ethiek van de gezondheidszorg, gezondheidsethiek of bio-ethiek' (Dupuis 1988a: 26). Hiermee gaf ze aan dat de bemoeienis met het terrein van de gezondheidszorg en de morele problemen in de gezondheidszorg sinds de jaren zeventig sterk was toegenomen. In het genoemde handboek schetste Dupuis, net als Sporken, het beeld van gezondheidsethiek als een ontwikkeling van artsencodes naar ethiek van de gezondheidszorg. De eerste artsencode zou uit de tijd van Hippocrates stammen. $\mathrm{Na}$ de Tweede Wereldoorlog zouden er in een stroomversnelling nieuwe codes gekomen zijn (Genève, Helsinki, Tokio). Deze codes hadden alle tot doel om de arts adviezen en aanwijzingen te geven voor een verantwoorde uitoefening van zijn beroep. In dezelfde categorie schaarde Dupuis ook de zogenoemde 'blauwe boekjes' over medische ethiek en gedragsregels voor artsen. Deze boekjes zijn door KNMG gepubliceerd in 1936,1959 en 1979 . In de codes was sprake van een tweetal regelingen: ten eerste regelingen van relaties tussen de beroepsgenoten onderling en de relatie van de beroepsgenoten tor de patiënten en ten tweede regeling van de relatie van de arts tot de samenleving en overheid. ${ }^{17} \mathrm{Na} 1965$ zou het thema van 
het mondiger worden van de patiënt telkens zijn teruggekeerd in de literatuur. Op grond hiervan claimde Dupuis dat medische ethiek na 1965 een maatschappelijke aangelegenheid was geworden: 'Medische ethiek is een zaak van allen geworden; de invloed van niet-artsen op de morele bezinning rond het medisch handelen wordt duidelijk zichtbaar. Dit is ook de periode dat de ethicus en de jurist de poorten van het "Bolwerk der beterweters" bestormen' (Dupuis 1988a: 25). Dupuis schreef aan Sporken de poging toe om te breken met de klassieke term 'medische ethiek' (een ethiek vàn en vóór medici) en de bredere term 'ethiek van de gezondheidszorg' in te voeren.

Het thema van de verbreding werd eind jaren negentig ook aangehaald door de auteurs van het handboek Medische ethiek (Ten Have \& Ter Meulen et al. 1998: 27). De auteurs, allen hoogleraar ethiek op het terrein van de gezondheidszorg, gaven een schets van de ontwikkeling van medische ethiek als beroepsethiek waarbij aanvankelijk de nadruk lag op de 'deugdzaamheid van de beroepsbeoefenaar'. Vervolgens kwam er aandacht voor onderlinge collegiale relaties en tenslotte kwam de wetenschappelijke competentie van ethici meer centraal te staan. De ethiek heeft zich volgens hen dus ontwikkeld van een ethiek van en voor artsen naar een patiëntgerichte oriëntatie in de medische ethiek. ${ }^{18}$ Deze verbreding brachten zij niet tor uitdrukking, in tegenstelling tot sommige andere ethici, in de titel van hun handboek. Daarin werd - nog steeds over medische ethiek gesproken. Fnerzijds waren de auteurs, ondanks de veranderingen, van mening dat de harde kern van de medische ethiek herzelfde was gebleven: er is iemand die zich met een klacht wendt tot een arts en van deze arts hulp verwacht. De hulpvragende patiënt zou nog steeds beginpunt en eindpunt van het medisch denken en handelen zijn (Ten Have \& Ter Meulen et al. 1998: 44). Anderzijds werd volgens hen met de term 'gezondheidsethiek' ten onrechte gesuggereerd dat ethische beschouwingen een bijdrage zouden leveren aan het instandhouden en bevorderen van de gezondheid (p. 42). Niettemin gaven ze aan dat de term gezondheidsethiek zeer gangbaar was geworden.

Ner als bij het gezondheidsrecht is er dus ook bij de gezondheidsethiek sprake van verschillende benamingen. Dat het vakgebied aan verandering onderhevig is, wordt door de meeste ethici onderkend. Deze veranderingen worden echter verschillend geïnterpreteerd. Achter het thema van de verbreding van de ethiek gaan diverse invullingen schuil. Enerzijds lijkt er een bepaalde opeenvolging in de tijd te worden gevolgd. De keuze van de gebruikte terminologie wordt dan bepaald door welke afbakening of aanduiding van het vakgebied men voor ogen heeft. Eerst was er medische ethiek, vervolgens ethiek van de gezondheidszorg, gezondheidsethiek en inmiddels ook, niet als alternatief maar als indicatie voor de uitbreiding van het terrein met ethische kwesties ten aanzien van het welzijn van dieren en voedsel: de bio-ethiek. Er is dus niet zoals bij het recht eerst strijd gevoerd over welke rerm wordr gekozen, waarna vervolgens alle betrokke- 
nen deze term consequent hanteren. Anderzijds bestaan de verschillende termen nu naast elkaar en worden om diverse redenen gebruikt.

\section{Kritische geluiden}

Er bestaan dus kennelijk verschillende visies op de inhoud en omvang van de ethiek. De aanduiding van de discipline is afhankelijk van de vraag of men (problemen rond) de patiënt centraal stelt, of ook ontwikkelingen in de gezondheidszorg of breder nog ook het welzijn van dieren en ethische kwesties rond voeding in de beschouwing betrekt. Ook aan de kritische geluiden, die vanaf eind jaren tachtig de gezondheidsethiek in Nederland aan felle kritiek hebben onderworpen, liggen verschillende opvattingen over de rol en functie van het vakgebied ten grondslag. Uit deze kritiek blijkt dat er onenigheid is over welke functie men voor de ethiek in gedachten heeft. Dit varieert van onvrede over de relatie tussen ethiek en medische technologie tot meningsverschillen over welke functie ethiek ten opzichte van de geneeskunde of gezondheidszorg zou moeten hebben; oplossingsgericht, kritisch of juist meer gericht op empirisch onderzoek.

Het boek Geneeskunde tussen droom en drama is een kritische beschouwing over de relatie tussen medische ethiek en medische technologie (Ten Have \& Kimsma 1987). Hierin schreven de auteurs de ethiek onmacht toe. De groei van de medische ethiek liep volgens Ten Have en Kimsma niet evenredig met de mate van haar invloed op her medisch handelen. Erhiek mocht dan wel een grote populariteit genieten, het effect ervan op het medisch handelen en op wetenschappelijke ontwikkelingen was maar klein (p. 175). Als er al effecten te vinden waren, dan was dat voornamelijk in de vorm van procedurele regelingen die de geneeskunde stroomlijnden. In feite liep de ethiek achter de ontwikkelingen aan. Het probleem van de onmacht van de ethiek hing volgens Ten Have en Kimsma samen met het gegeven dat ethische vragen over medische technologie vaak buiten de discussie werden gelaten. Technologie werd volgens hen ten onrechte als moreel neutraal beschouwd. De impliciet ethische uitgangspunten van technologie bleven daardoor onder de oppervlakte hangen. Het idee dat ethische problemen pas ontstaan als technologie ten goede of ten kwade wordt aangewend, leidde ertoe dat in ethische discussies de vraag naar het morele karakter van technologie niet werd gesteld. Hun conclusie luidde dat ethische discussies zich daardoor noodgedwongen richtten op de toepassingsvoorwaarden van reeds ontwikkelde technologieën (p. 185). Ethiek vormde op die manier een legitimerende functie voor allerlei medische ontwikkelingen en was als zodanig in de ogen van Ten Have en Kimsma niet kritisch genoeg.

Zoals ook in de tweede paragraaf al is genoemd, is er door Nijmeegse ethici ernstig kritiek geuit op de toegepaste ethiek en de functie die deze zou hebben. 
De ethiek zou zich volgens een aantal critici moeten ontworstelen aan het technische juk waar ze onder gebukt ging. De toegepaste ethiek beperkte zich te veel tot de smalle moraal, maar de vraag 'hoe te leven?' zou volgens de filosoof Van Tongeren juist in de context van een brede moraal moeten worden beantwoord (Van Tongeren 1988). Een voorbeeld van een smalle of technische ethiekopvatting is terug te vinden bij Van Willigenburg, hoogleraar ethische aspecten van de gezondheidszorg in relatie tot de humanistische levens- en wereldbeschouwing. Hij duidde zichzelf met de geuzennaam 'ethisch ingenieur' aan (Van Willigenburg 1993). Zijn definitie van een echisch ingenieur luidde: 'iemand met een eigen specifieke deskundigheid in het door middel van systematische reflectie hanteerbaar maken van concrete morele problemen'. Van Willigenburg omarmde dus een ingenieursmodel van ethiek; praktische ethiek was eenvoudigweg gericht op probleemoplossing. De belangrijkste bijdrage van een ethisch ingenieur zou bestaan uit het ontwikkelen, aanbieden en testen van op de praktijk toegesneden methodieken voor concrete probleembehandeling, aldus Van Willigenburg. Dat kwam neer op een soort morele besliskunde. Het al eerder genoemde ethisch stappenplan is een uitwerking van deze vorm van echiek beoefening.

Zwart, filosoof en psycholoog, was kritisch ten opzichte van dit type ethicus als 'technisch ingenieur' en deelde de kritiek van Van Tongeren (Zwart 1992). Het was volgens hem de taak van een ethicus om de betekenisvolle achtergrondmoraal te achterhalen die schuilging onder een medisch-ethisch dilemma. Dit is de reden waarom een ethicus voor een brede ethiekopvatting zou moeten kiezen. Medische ethiek zou recht behoren te doen aan de ervaring van 'dubbelheid' die deel uitmaakt van de morele dimensie van ons bestaan, zoals die in verschillende tradities verwoord wordt. Medische ethiek zou zich volgens Zwart hebben laten reduceren tot morele helper van de geneeskunde (Zwart 1995). Hij was van mening dat de ethiek zich had beperkt tot het leveren van oplossingen voor problemen in de geneeskunde. In plaats daarvan zou ze juist de geneeskunde voortdurend moeten problematiseren en fundamentele problemen aan de orde moeten stellen. Met andere woorden: ethiek moest ethiek blijven en mocht geen technisch instrument worden, waarmee maatschappelijke vraagstukken zouden worden opgelost of beleidsbeslissingen gelegitimeerd. Het ging volgens Zwart bij ethiek niet zozeer om de vraag wat de meest rationele oplossing was voor bepaalde morele situaties, maar om de vraag wat de betreffende probleemsituatie zo problematisch maakte. Verheldering hiervan was de taak voor ethiek in de ogen van Zwart. ${ }^{19}$

De huisarts en filosoof Willems was het in grote lijnen eens met de diagnose van Zwart (Willems 1995). Willems kon zich echter niet vinden in de therapie die Zwart voorstelde: terug naar de primaire ervaring. Volgens Willems kon de ethiek haar krirische functie ten opzichte van de geneeskunde niet veilig stellen 
door zich terug te trekken in zo'n 'mystieke oerervaring'. Ethiek zou juist de geneeskunde nauwkeurig in kaart moeten brengen en daarop haar kritiek baseren. Willems schreef een nieuw recept uit: minder primaire ervaring, meer empirisch onderzoek. ${ }^{20}$

Ook uit andere hoek is begin jaren negentig eveneens stevige kriciek gekomen op een oplossingsgerichte beoefening van de ethiek. Een relatieve buitenstaander, de wetenschapsfilosoof De Vries, trok in het boekje Gerede twijfel. Over de rol van medische ethiek in Nederland van leer tegen ethici die een rationele en oplossingsgerichte ethiek nastreefden (De Vries 1993a). Deze ethici zouden volgens hem proberen om tragedies 'om te toveren' in conflicten waarvoor rarionele oplossingen zouden bestaan; ethici als 'amateur-juristen'. ${ }^{21} \mathrm{Op}$ die manier zouden ethici volgens De Vries een kader claimen, waarin morele problemen op een rationele manier behandeld konden worden. De Vries was echter van mening dat tragedies ons confronteren met de grenzen van onze taal. Ethici zouden dus hooguit gedeeltelijk antwoord kunnen geven op de prangende vragen die ze krijgen voorgeschoteld. Zijn kritiek was met name op Dupuis gericht. Hij illustreerde zijn kritiek namelijk aan de hand van een lezing getiteld 'De Woede van Heleen Dupuis'. Deze lezing ging over medische beslissingen rond een te vroeg geborene met een aantal complicaties. Dupuis heeft op haar beurt, aan de hand van dezelfde casus, uiteengezet wat haar bezwaren waren tegen een ethiek die meer uitgaat van concrete interpretaties van dagelijkse ervaringen dan van abstracte redeneringen (Dupuis 1996). Onder de aanhangers van deze vorm van ethiek waar zij zich tegen afzette, de narratieve ethiek, schaarde zij Van Tongeren, Zwart en De Vries.

Naast invullingen van de ethiek als narratieve ethiek heeft zich ook een erhiek van de zorg of zorgethiek ontwikkeld. Deze vorm van ethiek werd voorgesteld als een alternatief, naast de ethiek waarin het rechtendiscours centraal staat. De bundel Ethiek van de zorg vormde de aanzet tot een programma voor de zorgethiek (Manschot \& Verkerk 1994). Het streven naar een ethiek van de zorg was geboren uit kritiek op het zogenoemde contract denken in de maatschappij en in de ethiek in het bijzonder. Volgens één van de redacteurs van het boek zou hierdoor elk handelen dat niet binnen het contractuele paradigma paste, zoals handelen in de context van meer persoonlijke relaties, gemarginaliseerd worden (Verkerk 1994). Daarom zou een zorgethisch discours, met een nadruk op betrokkenheid en sympathie, zowel het private als publieke leven moeren gaan doorkruisen. Morele problemen zouden in de eerste plaats in termen van de verantwoordelijkheid van mensen ten opzichte van elkaar begrepen moeten worden. Halverwege de jaren negentig vormde de genoemde bundel niet meer dan een aanzet voor een kritisch programma. Later heeft de zorgethiek een breder draagvlak weten te vinden (Sevenhuijsen 1996; Verkerk 1997; Widdershoven 2000; Reinders 2000). 
De meningsverschillen over de functie en betekenis van ethiek zijn groot. Enerzijds zou zij idealiter een oplossingsgerichte functie moeten hebben. Middels een ethisch stappenplan zou volgens een standaardaanpak een oplossing gevonden moeten worden voor diverse ethische problemen in de geneeskunde en de gezondheidszorg. Anderzijds werd gepropageerd dat juist in een dergelijke oplossingsgerichte ethiek te weinig ruimte zou zijn voor een kritische houding ten opzichte van de context van de erhische problemen die zich voordoen. De ethiek zou dan haar beoogde reflexieve functie verliezen. In de ogen van deze critici is het juist de taak van de ethiek om fundamentele vragen te stellen, empirisch onderzoek te doen, aandacht te hebben voor de morele ervaring bij en het tragische karakter van medisch-ethische dilemma's of een meer zorgethische houding in plaats van op zoek te gaan naar een oplossing.

Tot slot, ethiek binnen de geneeskunde of de gezondheidszorg is geen nieuw fenomeen evenmin als het gezondheidsrecht. De huidige benaming gezondheidserhiek wordt breed gedeeld. Dit belemmert echter niet het circuleren van andere benamingen, die evengoed worden erkend. Er heeft niet, zoals bij het recht, in het begin een openlijke begrippenstrijd gewoed waaruit één term als 'winnaar' uit naar voren is gekomen. Het verschil in aanduiding is vooral gelegen in de visie die men heeft op de aard of de reikwijdte van het gebied bij de beoefening van de ethiek. De gezondheidsethiek is minder homogeen dan het gezondheidsrecht. Het retrospectief aanwijzen van een spin in het web, zoals bij het recht, is niet mogelijk. Er is voortdurend kritiek op elkaar over de wijze waarop het vak wordt beoefend. De echiek is kennelijk een reflexiever vak dan het rechr, of anders gezegd er is tot dusverre een meer vruchtbaar klimaat voor interne kritiek dan bij het recht.

\section{De relatie tussen gezondheidsethiek en gezondheidsrecht}

Over de relatie tussen de disciplines gezondheidsrecht en gezondheidsethiek in Nederland is een bescheiden hoeveelheid publicaties tot stand gekomen. Op het eerder in dit hoofdstuk genoemde congres van Katholieke Artsen, halverwege de jaren vijftig, was het een aandachtspunt, toen het concept medisch recht voor het eerst ter sprake kwam. De vraag op dit congres luidde wat de verhouding zou moeten zijn tussen medisch recht en medische ethiek. "' Het bleef bij een vraag.

Sindsdien wordt in de literatuur over dit onderwerp de relatie tussen recht en ethiek op verschillende manieren gekarakteriseerd. Sommige auteurs benadrukken de verschillen tussen de vakgebieden om op die manier een eigen identiteit van het vakgebied te waarborgen. Anderen zoeken naar overeenkomsten en zien daarom of mogelijkheden voor samenwerking of juist kans op conflicten. Deze karakteriseringen van de relatie tussen ethiek en recht zijn te duiden 
als: een harmonieus evenwicht, een coöperatieve relatie, een potentiële conflict situatie of een concurrerende verhouding (de één groter dan de ander). In een evenwichtssituatie zouden ethiek en recht elkaar kunnen aanvullen of op zijn minst elk een eigen zinvolle bijdrage kunnen leveren aan de morele problematiek in de gezondheidszorg zonder elkaar in de weg te zitten. Als er daarentegen overlap in de taken of functies van de beide vakgebieden is bestaat er een grotere kans op wrijving, hoewel dit uiteraard niet meteen of automatisch tot conflictun hoeft te leiden.

Sporken stelde eind jaren zeventig dat in de discussie over medische vraagstukken de begrippen recht en ethiek vaak gebruikt werden alsof ze min of meer identiek zouden zijn. Hij ageerde hiertegen. Ethiek had volgens hem betrekking op het gewetensoordeel over de aard van het menselijk handelen, alsmede de innerlijke houding van waaruit een mens handelt. Het recht zou daarentegen vooral het maatschappelijk handelen van de mens regelen (Sporken 1977:36). Zo zou de strafwet verband houden met ethiek voorzover dit samenhangt met een bepaald mens- of maatschappijbeeld. Dit zou kunnen betekenen dat de strafwet in concrete gevallen juridisch meer toelaat (bijvoorbeeld abortus), dan ethisch geoorloofd is volgens sommige groepen. Dit betekent dat recht en ethiek volgens Sporken geen inwisselbare concepten zouden zijn. Sporken stelde dus dat de begrippen recht en ethiek onterecht als gelijken werden beschouwd. Zijn uiteenzetring impliceert dat elk een eigen gebied vertegenwoordigt, zonder dat dit meteen tot conflicten of concurrentie hoeft te leiden.

Eind jaren tachtig beklaagden Ten Have en Kimsma zich dat de ethiek een te ruime diversiteit aan normen toeliet. Dit leidde er volgens hen toe dar de vorming van een minimale ethische consensus steeds vaker aan het recht zou worden overgelaten. 'Eun discipline als het gezondheidsrecht, welke zich de afgelopen decennia eveneens stormachrig ontwikkeld heeft, houdt zich dan ook steeds vaker bezig met ethische vraagstukken, waarbij de verschillen tussen recht en ethiek hoe langer hoe meer vervagen' (p. 14). Ze duidden de huidige (door hen kennclijk ongewenste) situatie aan als één waarin het recht te veel op het terrein van de ethiek zou zijn gaan zitten. Dit werd beschouwd als een problematische annexatie, want de veronderstelling is namelijk dat de ethiek daardoor een deel van haar identiteit zou verliezen. Ten Have en Kimsma vinden dat ethici zich de kaas van het brood hebben laten eten, doordat het ze niet in staat bleken te zijn om op een goede of succesvolle wijze om te gaan mer de diversiteit aan normen en waarden in onze huidige samenleving. Met andere woorden, dit is een mogelijke conflictsituatie. De normatieve boodschap in hun beklag luidt dat beide vakgebieden zich bij hun leest zouden moeten houden.

Leenen heeft in zijn handboeken gezondheidsrecht ook aandacht besteed aan de relatie tussen de disciplines gezondheidsrecht en gezondheidsethiek. Hij was van mening dat de disciplines deels overlappen (Leenen 1981: 2, 1988b: 17). 
De overlap bestaat uit het feit dat beide vakgebieden individuele en maatschappelijke waarden tegen elkaar afwegen. Bij beide gaat het om het bestuderen van de uitwerking van beginselen, normen en waarden in de gezondheidszorg. $\mathrm{Er}$ zou dus een soortgelijke aanpak bestaan. Een verschil daarbij is dat een jurist de wet, het recht en de rechtspraak niet uit het oog kan verliezen. Ethici willen hier volgens Leenen nogal eens aan voorbij gaan. In tegenstelling tot wat enkele ethici mogen denken kunnen sommige grenzen volgens hem niet verlegd worden. Als voorbeeld noemde Leenen levensbeëindiging zonder verzoek. Tussen levensbeëindiging op verzoek en zonder verzoek trekt hij een scherpe lijn. Ten tweede zou de ethiek wel (gedrags)normen kunnen voortbrengen, maar deze normen hoeven, in tegenstelling tot juridische normen, nier tevens juridisch bindend te zijn.

Enerzijds zou het recht volgens Leenen dus meer terrein beslaan dan de ethiek. Anderzijds stelt hij dat de ethiek ook verder kan gaan dan het recht. Dit kan het geval zijn als er een spanning bestaat tussen de wet en de ethiek, als een wettelijke regel tot onethisch gedrag zou leiden, bijvoorbeeld in staten waar geen democratisch regime geldt. Een ander geval waarin de ethiek strikter kan zijn dan het recht is wanneer er een strengere ethische norm geldt dan de juridische regel die op een bepaald minimum gericht is. Bijvoorbeeld bij euthanasie, waar het recht een beroep op zelfbeschikking gegrond acht. Voor sommigen is dit echter, vanuit religieuze overwegingen, niet acceptabel. Op grond van de overeenkomsten en de overlap, heeft Leenen voor samenwerking tussen de beide disciplines gepleit (Leenen 1993: 21, 2000: 90). Ondanks de overlap, en daarmee potentiële conflicten, bestaat er voor Leenen niet vanzelfsprekend een conflicterende relatie tussen recht en echiek.

Een soortgelijke analyse, maar met een tegenovergestelde boodschap, was te lezen in een boek over de verhouding tussen recht en ethiek getiteld De Siamese tweeling (Van der Burg \& Ippel 1994). Dit boek is uitgegeven door het Centrum voor Bio-ethiek en Gezondheidsrecht. Het centrale thema van her boek was de verstrengeling van recht en ethiek. 'Ze vormen een Siamese tweeling: grotendeels gelijk, deels met elkaar vergroeid en slechts beperkt zelfstandig ten opzichte van elkaar. (...) Het risico van zo'n sterke band is echter dat onvoldoende rekening kan worden gehouden met de eigen aard van recht en moraal, waardoor beide zich niet goed kunnen ontwikkelen' (Van der Burg \& Ippel 1994: I). Deze verstrengeling duidde volgens de auteurs op de feitelijke verhouding tussen recht en ethiek. Er werd gesproken over moralisering van het recht en juridisering en institutionalisering van de ethiek. ${ }^{23}$ Er zou van een - ongewenste - vermenging van de beide disciplines sprake zijn. Deze feitelijke verhouding kan worden omschreven in termen van een conflictsituatie. Het soort problemen en het soort kennis, dat volgens de auteurs gescheiden zou moeten zijn, liepen door elkaar. Idealiter zou er volgens hen een duidelijk verschil moeten bestaan tussen 
recht en ethiek. Voor de ethiek werd de filosofische oriëntatie genoemd, die van belang kan zijn in situaties waarin naar nieuwe wegen gezocht moet worden. Bij het recht werd juridische kennis genoemd van bepaalde problemen die elders bevredigend zijn opgelost (p. 7). De achterliggende gedachte is kennelijk dat er een 'vaste' omschrijving zou bestaan van recht en ethiek en hierbij aansluitend ook wat de wenselijke taak, functie en inhoud van beide disciplines zouden zijn.

In Medisch Contact is in 1997 een briefwisseling verschenen over gezondheidsrecht en gezondheidsethiek. ${ }^{24}$ Hierin probeerden de secretaris-arts van de KNMG Dillmann en de hoogleraar gezondheidsrecht Roscam Abbing hun gedachten over dit onderwerp nader te bepalen. In de inleiding van de hoofdredactie tot deze serie werd gesteld dat gezondheidsrecht en gezondheidsethiek tegenover hetzelfde object: de praktijk van de gezondheidszorg verschillende posities zouden innemen, omdat ze bij dezelfde casuïstiek tot uiteenlopende conclusies kunnen komen (Spreeuwenberg 1997). Juist die verschillende posities vormden het onderwerp van de briefwisseling. De auteurs probeerden een aantal kenmerken en overeenkomsten van beide disciplines voor het voetlicht te brengen. Zo stelde Roscam Abbing enerzijds dat beide disciplines vanuit dezelfde beginselen werken: autonomie, geen schade, rechtvaardigheid en weldoen. Ze sprak hierbij van het met deze begrippen bevruchten van het gezondheidsrecht door de gezondheidserhiek. Anderzijds zouden sommige gezondheidsethici rechtsbeginselen, bijvoorbeeld het zelfbeschikkingsrecht, soms te absoluut interpreteren zodat het ook een claim op voorzieningen zou inhouden. Voorts stelde Roscam Abbing dat een beginsel moest leiden tot een oplossing in een concretc situatie via analyse en argumentatie, waarbij consistentie door haar als zeer belangrijk werd beschouwd. Bij gezondheidsethiek zou de stap van beginsel tot oplossing nogal eens te kort zijn, omdat de analyse en argumentatie zouden ontbreken (Roscam Abbing \& Dillmann 199: 287).

Dillmann vestigde de aandacht op de diversiteit binnen de ethiek. De interne samenhang binnen de ethiek was volgens Dillmann minder groot dan bij het recht (Roscam Abbing \& Dillmann 1997). De ethiek zou niet de 'intensieve bewaking van opvattingen en redeneringen' kennen zoals die in de rechtspraak gelden. Door de jurisprudentie zou een jurist veel meer gedwongen worden om met zijn redeneringen binnen bepaalde kaders te blijven. 'Het juridische discours is dus veel meer dan het ethische discours onderhevig aan dwang' (p. 289). Dit heeft tot gevolg dar bij de ethick meer ruimte is voor diversiteit in theorievorming en redeneerwijzen. Zo zou er binnen de ethiek ook geen eenheid van taal te vinden zijn op het niveau van de ethische theorievorming. In tegenstelling tot het recht, want het recht zou de 'smalle moraal' vertolken en in die zin minder diffuus zijn.

Ten aanzien van de relatie tussen recht en ethiek stelde Dillmann: 'Om de samenhang tussen gezondheidsrecht en -ethiek duidelijk te maken, moeten we 
in ieder geval aangeven dat beide niet samenvallen, en dat beide iets zichtbaar maken dat de ander laat liggen, naast het gebied waarin zij overlappen' (p, 222). Verschillen waren er volgens hem bijvoorbeeld in de manier waarop er aandacht was voor het mensbeeld. Zo zou de vraag naar een positieve vormgeving van het menselijk bestaan meer aandacht krijgen bij de gezondheidsethiek. Ten tweede had ethiek volgens Dillmann ook sterker de neiging om zich in te werken in nieuwe ontwikkelingen. Het recht kwam in het kielzog om aan te geven of het allemaal wel zou kunnen volgens de verschillende verdragen. 'Daarbij probeert het gezondheidsrecht veelal het nieuwe te duiden in termen van het reeds bekende. Kortom: de ethiek verkent, het gezondheidsrecht herkent' (Roscam Abbing \& Dillmann 1997: 222). De claims van Roscam Abbing en Dillmann over de verhouding tussen gezondheidsethiek en gezondheidsrecht zoeken het midden tussen een harmonieuze relatie en een potentiële conflictsituatie. De volgende paragraaf gaat verder in op de vraag welke - impliciete vooronderstellingen er achter de verschillende karakteriseringen in bovenstaande literatuur schuil gaan en welke betekenis dit heeft voor de vraagstelling van het onderzoek.

\section{Ontwikkeling van en verhouding tussen disciplines}

Een eerste kennismaking met de disciplines gezondheidsrecht en gezondheidsethiek levert een aantal overeenkomsten en verschillen op. De overeenkomsten liggen bij de aard van de disciplines en het terrein van het bestudeerde object. Het zijn beide disciplines die zich bezighouden met (normatieve) problemen in de gezondheidszorg. Bovendien zijn zowel recht als ethiek, blijkende uit de verschillende (ethische) commissies, geïnstitutionaliseerd. Een verschil is gelegen in de opzet van de handboeken of leerboeken voor beide disciplines. Bij het recht ligt het 'monopolie' hiervoor al ruim twintig jaar, sinds het verschijnen van het eerste handboek gezondheidsrecht, voor het overgrote deel in handen van één auteur. Daar spreekt een grote invloed op de invulling van het vakgebied uit. Bij de ethiek is er sprake van diversiteit; er is in de loop der jaren niet één hoofdauteur aan te wijzen, noch een eenduidig concept voor het schrijven van handboeken te vinden. Dit zou deels een verklaring kunnen zijn voor de relatieve homogeniteit en coherentie van het recht en de diversiteit (verschillende stromingen en opvattingen over wat de rol en invulling van de ethiek zou moeten) binnen de ethiek.

Her zelfbeeld van de ethiek laat zien dat er meerdere benamingen naast elkaar bestaan, namelijk: medisch ethiek, gezondheidsethiek en bio-ethiek. De groei van het recht wordt door Leenen aangeduid in termen van vraag en aanbod; er was in de maatschappij steeds meer behoefte aan reflectie op het terrein 
van het recht en de gezondheidszorg. Dit heeft de vraag naar het recht doen ontstaan en toenemen. De zelfbeelden geven een idee hoe volgens betrokkenen de disciplines gestalte hebben gekregen. Door verklaringen te geven in termen van exrerne factoren (maatschappelijke ontwikkelingen als verklarende factor) wordt gesuggereerd dat er een min of meer vanzelfsprekende ontwikkeling ten grondslag ligt aan de groei van het vakgebied. Dit maakt het werk dat met het vormgeven aan de inhoud en afbakening van het vakgebied gepaard is gegaan, ondergeschikt aan de maatschappelijke ontwikkelingen.

Ten aanzien van de verhouding tussen recht en ethiek bestaan er, zoals de literatuur in de vorige paragraaf liet zien, verschillende (normatieve en descriprieve) claims. De typeringen over de relatie tussen ethiek en recht variëren grofweg van een harmonieuze relatie tot een conflictsituatie. Deze karakteriseringen over de relatie tussen recht en ethiek suggereren stuk voor stuk dat beide disciplines los van elkaar kunnen bestaan. Ze gaan uit van een vast objectgebied voor zowel de ethiek als het recht. Enerzijds kan dit objectgebied betrekking hebben op een zelfde deel van de werkelijkheid, waarbij er mogelijk concurrentie bestaar of een potentieel conflict. Een voorbeeld hiervan is de relatie tussen recht en ethiek zoals deze is geschetst in het boek De Siamese Tweeling. Er wordt over een - ongewenste - verstrengeling van de beide vakgebieden gesproken. Het idee hierachter is dat er wel twee gescheiden objectgebieden zouden moeten zijn, maar dat deze in de praktijk teveel naar elkaar toe zijn gegroeid. Anderzijds kan het objectgebied géén overlap vertonen. Dan weerspiegelen beide vakgebieden (op zijn minst) een eigen deel van de werkelijkheid. In dat geval is de kans op een harmonieuze relatie tussen recht en ethiek groter. Deze voorstelling van zaken is bij Sporken terug te vinden. Hij kende beide vakgebieden een eigen gebied toe.

In dit onderzoek worden de ontwikkeling en onderlinge verhouding tussen gezondheidsethiek en gezondheidsrechr bestudeerd. Het onderzoek vertrekt vanuit het idee dat er een dynamiek bestaat tussen beide vakgebieden; grenzen verschuiven voortdurend en de afbakening van de discipline is geen vanzelfsprekendheid. Dit betekent dat in de typeringen over de relatie tussen recht en ethiek ten onrechte van vaste verhoudingen wordt uitgaan, omdat men veronderstelt dat een discipline een afgebakend deel van de wetenschappelijke werkelijkheid bestrijkt. Deze typeringen zijn te statisch om als uitgangspunt voor de onderzocksvraag te dienen. Enerzijds houden de claims onvoldoende rekening met het gegeven dat, als gevolg van het ontstaan van nieuwc thcorieën of onderzoeksprakrijken, ook het objectgebied van karakter kan veranderen. Anderzijds kunnen ook de problemen en het soort kennis waarin men geïnteresseerd is veranderen. Een nieuwe taakverdeling tussen disciplines is niet zelden een proces dat met strijd gepaard gaat (Abbott 1988; Gieryn 1983). Op grond hiervan is het lastig om disciplines te beschouwen als natuurlijke eenheden die zich op grond van enkele onveranderlijke kenmerken laten onderscheiden. 
Kurtom, de zelfbeelden zijn niet geschikt om de onderzoeksvraag te beantwourden.' $\Gamma$ en eerstc wordt er bij het schrijven van de eigen geschiedenis vanuit gegaan dat her vakgebied een min of meer autonome ontwikkeling, onder invloed van maatschappelijke tendensen, heeft ondergaan. Het werk dat daadwerkelijk is verzer om het vakgebied vorm en inhoud te geven blijft hierdoor onbelicht. Ten tweede kan dit onderzoek bij de reconstrucrie van de ontwikkeling van gezondheidsethiek en gezondheidsrecht zich nier mer ethici of juristen identificeren, het gaat namelijk om de bestudering van de relatie tussen de twee disciplines. Beide disciplines zouden idealiter vanuit een buitenstaandersperspecief, in dit geval een sociaal-wetenschappelijk perspecticf, symmetrisch behandeld moeten worden. In dit onderzoek wordt het sociaal-wetenschappelijke perspectief vertegenwoordigd door de in hoofdstuk één genoemde drievoudige theoretische exercitie. Ten derde gaan de claims in de literatuur over de verhouding tussen beide vakgebieden uit van een vaste identiteit voor beide vakgebieden. Dit uitgangspunt wordt in de volgende drie hoofdstukken ter discussie gesteld door juist de aandacht te vestigen op de interactie in de verhouding tussen de disciplines. 


\section{DEFINITIES, AFBAKENING EN STRIJD BIJ KWESTIES}

ROND HET LEVENSEINDE

"Het is nu eenmaal niet de taak van de arts een oordeel te vellen over de zin van het lijden of de zin van het bestaan zelf." Met deze uitspraak ben ik het eens, indien achter "taak" het woord uitsluitend wordt ingevoegd. Daarom stel $i k$ de vraag of het leven door de arts mag worden bekort, of juister geformuleerd, het sterven mag worden versneld, bepaald niet alleen een medische aangelegenheid is, maar een vraagstuk dat terzelfder tijd om benadering vraagt, door ethicus, moraaltheoloog, jurist en anderen.'

(Muntendam 1977)

De opkomst van reanimatie- en beademingstechnieken en ook transplantatiemogelijkheden in de afgelopen jaren vijftig en zestig betekende een ommekeer in het medisch denken over leven en dood. Er moesten nieuwe afspraken komen over de scheidslijn tussen leven en dood. Het criterium van ademhalings- en hartstilstand, geconstateerd door een arts, was niet meer houdbaar. Door de mogelijkheid van reanimatie en beademing ontstond onzekerheid omtrent de grens tussen leven en dood. Patiënten bleken in een fase tussen leven en dood te kunnen verkeren. De definitie van 'dood' voldeed niet meer en was aan herziening toe. Het onomkecrbare moment van de dood leek namelijk verder weg te liggen dan men vroeger meende. Dat riep tal van vragen op. Wanneer kon een reanimatiepoging worden gestaakt? Welke criteria moesten daarbij gelden? Levensbekortend handelen door artsen was geen normaal medisch handelen. De buitenwereld raakte bij het vraagstuk betrokken. Dit werd nog versterkt door hierop volgende ontwikkelingen op het gebied van orgaantransplantarie. Daar worstelde men met de vraag op welk moment ingrijpen in het proces van kunstmatige verlenging van het leven, met het oog op transplantatie, gerechtvaardigd was. Ten behoeve van het donorschap was snel handelen - zo bleek - van groot belang. In deze periode kristalliseerde het criterium van hersendood, voor het vaststellen van de dood, uit. De definitie van dood als harten ademhalingsstilstand leek niet meer adequat te zijn. Er ontstond discussie - tussen verschillende disciplines - over de vraag of, en zo ja op welk tijdstip, en onder welke voorwaarden men gerechtigd kon zijn in het stervensproces in te grijpen. Deze vragen vormden de aanleiding voor het debat over levensbekortend handelen in een medische context. 
Dit eerste empirische hoofdstuk laat de dynamiek zien rond begrippen en probleemdefinities zoals euthanasie en hulp bij zelfdoding, of ruimer levensbekortend handelen in een medische context. Het uitgangspunt is dat er geen vaste afbakening van de verschillende noties in het debat bestaat. Het is de bedoeling te onderzoeken hoe de betekenis van dergelijke definities, concepten en onderscheidingen in de loop van het debat vorm krijgt en verschuift. Het gaat om de implicaties die dit heeft voor de betrokken disciplines. In dit hoofdstuk wordt geen normatieve benadering gehanteerd (is de huidige definitie van euthanasie wel een juiste aanduiding voor de problematick?), maar ook geen historische benadering pur sang (hoe is het euthanasiedebat precies verlopen in Nederland?). De volgende empirisch-historische vraag staat centraal: hoe hebben de verschillende begrippen - zoals euthanasie en medische beslissingen rond het levenseinde - gestalte gekregen en hoe heeft zich dat verhouden tot de rol en functie van de betrokken actoren en disciplines? De aandacht is, in het verlengde van de onderzoeksvraag, primair gericht op gezondheidsrecht en gezondheidsethiek.

\section{Theoretisch kader}

Om de ontwikkeling van disciplines te onderzoeken hanteert de socioloog Abbott een contextuele benadering van historisch professionaliseringsonderzoek (Abbott 1988). Hij bekritiseert daarmee voorgaande professionaliseringsstudies waarin de vorm van professies (proto-typen) centraal staat en niet de inhoud. Volgens traditionele theorieën zouden professies zich namelijk volgens een gemeenschappelijk patroon ontwikkelen (Wilensky 1964). Een voorbeeld hiervan is een - opeenvolgende - oprichting van: een trainingsinstituut, universiteit, lokale organisatie, nationale organisatie, een wettelijk vastgelegde erkenning en tenslotte een ethische code. De vraag die vervolgens opkwam was waaróm professies een bepaald verloop vertoonden. De aandacht verschoof van vorm (zichtbare kenmerken) naar functies (bijvoorbeeld het streven naar exclusiviteit). Ethische codes zouden niet het eindpunt van een verloop zijn, maar juist een manier om anderen buiten te sluiten. In traditionele professiesociologische theorieën heeft men dus altijd op de structuur van de professieontwikkeling - het zoeken van een bepaalde functie - gefocust. De inhoud van het werk dat professies doen is daarin minder belangrijk. De veronderstelling van veel van deze theorieën is daarnaast dat veranderingen zich in een vaste volgorde voltrekken.

Daarmee wordt volgens Abbott voorbijgegaan aan de relaries tussen professies: de interprofessionele competitie. Dit betekent dat het beheersen en toepassen van bepaalde kennis door buitenstaanders kan worden overgenomen, die in 
een mogelijk onderlinge strijd, op basis van inhoudelijk argumenten, willen gaan domineren. Als een professie zeggenschap over een bepaald gebied opgeeft, is dat voor een andere professie aanleiding om dat gebied te claimen. Abbott stelt aldus de inhoud van het werk centraal: de dynamiek die ontstaat als gevolg van het claimen van bepaalde taken en definities van problemen. Met name her claimen van zeggenschap over grensgebieden tussen professies leidt tot conflicten, interne tegenstellingen tussen professies en onderlinge concurrentie. Hiermee benadrukt hij de open dynamiek van professionalisering en het netwerk van onderlinge afhankelijkheid waarin professies opereren. In tegenstelling tot de traditionele uni-lineaire modellen ontwikkelen professies zich volgens Abbott als er niches zijn waarin ze zeggenschap kunnen uitoefenen. Deze dynamiek duidt Abbott aan als het systeem van professies: het complexe, dynamische netwerk van een cluster van beroepen, met daarbij alle interne worstelingen over werkterrein, mandaten en wettelijke legitimering. Veranderingen werken door in het hele systeem. In die zin getuigt Abbott van een ecologische visie op het systeem van professies. Zijn perspectief van inhoud, in plaats van de vorm, functioneert als heuristiek voor de onderzoeksvraag: hoe hebben gezondheidsethiek en gezondheidsrecht zich ontwikkeld als disciplines en hoe hebben ze legitimiteit weten te verwerven binnen een medisch-morele context?

Een goede historische studie naar professies begint volgens Abbott bij casestudies naar jurisdictie en jurisdictiedisputen (Abbott 1988). Hij definieert drie analytisch onderscheiden, maar de facto nauw met elkaar verweven arena's: de publieke arena, de regelgevende arena en de arena van de werkplek. Elke professie heeft een bepaalde vorm van jurisdictie (zeggenschap) over zijn activiteiten binnen deze arena's. In zijn theorie gaat Abbott uit van bestaande professies. De vraag wanneer je kunt spreken over het ontstaan van een discipline of professie is voor Abbott minder interessant. Het is volgens hem niet van belang wat bij een discipline het eerst wordt opgericht (beroepsorganisatie, tijdschrift, opleiding e.d.), omdat dat slechts zichtbare uitkomsten zijn van veel belangrijker gebeurtenissen op het inhoudelijke vlak (Abbott 1991). In dit hoofdstuk wordt dan ook niet het ontstaan van gezondheidsrecht en gezondheidsethiek als afzonderlijke disciplines centraal gesteld, maar juist de onderlinge dynamiek. Pogingen tot het definiëren en afbakenen van de onderhavige issues worden beschouwd als een kwestie van zeggenschap over het werkterrein. Het debat over levensbekortend handelen in een medische context vormt de arena waarin deze jurisdictiedisputen worden onderzocht.

Maatschappelijke problemen zoals euthanasie en hulp bij zelfdoding zijn vaak het resultaat van een complex interactieproces tussen diverse actoren. In het debat over levensbekortend handelen in een medische context vinden verschillende verschuivingen plaats: bepaalde ontwikkelingen worden als oorzaak van het probleem aangeduid, de zeggenschap over de kwestie verschuift, er 
worden nieuwe begrippen en onderscheidingen geïntroduceerd, er komen definities tot stand en er worden verantwoordelijkheden in de richting van een oplossing toebedeeld. In de arena van 'vragen rond het levenseinde' zijn macht, invloed en autoriteit niet gelijk verdeeld. De socioloog Gusfield levert een specifieke heuristiek om deze 'arena' te onderzoeken. Dit biedt diverse aanknopingspunten, die nauw aansluiten bij het uitgangspunt van jurisdictie door Abbott. Het verschil is dat Gusfield een maatschappelijk probleem (in plaats van de ontwikkeling van professies) als invalshoek nam en koos voor de metafoor van 'eigendom' om de bovengenoemde processen aan te duiden (Gusfield 198r). Het onderhavige onderzoek vertrekt vanuit her idee dat artsen minder exclusieve zeggenschap hebben gekregen over morele kwesties in de gezondheidszorg. De zeggenschap is verspreid, omdat er meer mensen bij betrokken zijn geraakt met name ethici en juristen. ${ }^{2}$ De vraag is dan wie er verantwoordelijk wordt geacht voor de oplossing van het betreffende probleem? Claims op het terrein van begrippen en definities houden verband met zeggenschap over de betreffende kwestie. Dat zegt niet alleen iets over het probleem zelf, maar ook over degenen die deze claims maken. 'Eigendom' constitueert een deel van de structuur van een maatschappelijk probleem. Het geeft aan waar macht ligt met betrekking tot het vorm en inhoud geven aan een probleem. Dit geeft ons een idee van wie er bij betrokken is, maar nog niet wat dit voor consequenties heeft. Gusfield voegde daarom nog twee concepten aan zijn sociologisch perspectief op de definitie van maatschappelijke problemen toe: causale verantwoordelijkheid en politieke verantwoordelijkheid (wat moet er, door wie, aan worden gedaan?). Het toebedelen van causale verantwoordelijkheid heeft betrekking op opvattingen en handelt over de vraag 'waardoor is het probleem ontstaan'? Politieke verantwoordelijkheid heeft betrekking op beleid en gaat over de vraag: wat moet er door wie aan het probleem worden gedaan? Politiek verantwoordelijke is degene die geacht wordt het probleem op te lossen. Diegene staat dan ook bloot aan kritiek bij het mislukken ervan en niet zelden probeert de actor die het probleem in eigendom heeft de politieke verantwoordelijkheid door te schuiven. Kortom, niet iedereen heeft evenveel invloed en mogelijkheden om de te hanteren begrippen en het onderhavige probleem te definiëren. Begrippen en definities vormen tegelijkertijd de definiëring van een probleem of object, alsook een strategische handeling met betrekking tot dat probleem. (Taal)handelingen zijn interventies in het debat. Het gaat om beheersing, verdeling, exclusiviteit en mogelijke verliezen in een poging om praktijken vorm te geven.

De theoretische noties van Abbott en Gusfield inspireren er toe om het euthanasiedebat als arena op te vatten en leiden tot een aantal onderzoeksvragen. Ten eerste, hoe ziet de arena van (relevante) betrokken actoren rond levensbeëindigend handelen er uit? Ten tweede hoe wordt het probleem van levensbeëindigend handelen aangeduid en afgebakend en hoe ontwikkelt zich 
dit verder gaandeweg het debat? Vervolgens, hoe verhoudt zich dit tot de rol en de positie van de betrokken actoren en disciplines in de arena? Wie eist er zeggenschap op over het probleem en hoe worden causale en politieke verantwoordelijkheden gedistribueerd? Met deze analyse wordt beoogd te laten zien dat ethiek en recht geen gegeven disciplines zijn met een vaste identiteit, maar in het debat over levensbekortend handelen in een medische context als disciplines gemaakt worden en dat de context daarbij van belang is. Het hoofdstuk is als volgt opgebouwd: in de tweede paragraaf wordt een beeld geschetst van het openbreken van de zeggenschap van morele vragen rond het levenseinde. Vervolgens komen de wording en gevolgen van een breed gedragen probleemdefinitie in termen van een toenemende medische macht aan de orde. Het hoofdstuk eindigt met de positie van de betrokken actoren bij eerst een versmalling en vervolgens een verbreding van her debat.

\section{Kiezen tussen verlengen of niet verlengen van het leven}

\section{Geen 'verlenging' van het leven en artikel 293 Wetboek van Strafrecht}

Wat anno 2000 in Nederland onder euthanasie wordt verstaan is het product van decennialang meningsvorming door de diverse betrokkenen. Opvallend is dat de begripsomschrijving van euthanasie in dit proces is veranderd. In Nederland wordt euchanasie sinds halverwege de jaren tachtig meestal omschreven als: opzertelijk levensbeëindigend handelen door een ander dan de betrokkene op diens verzoek. In het buitenland gelden weer andere definities die doorgaans ook het handelen of niet-handelen inzake het verkorten van het leven omvatten. Het Nederlandse euthanasiebegrip heeft slechts betrekking op een deel van de dilemma's van levensbekortend of levensbeëindigend handelen, waaronder ook de hulp bij zelfdoding, de discussie over wilsonbekwamen en aanvankelijk (en deels in het buitenland) ook bepaalde niet-behandelbeslissingen vallen. Voor wilsonbekwamen gaat het 'op diens verzoek' namelijk niet op. Deze categorie van beslissingen wordt de laatste jaren aangeduid als Medische Beslissingen rond het Levenseinde (MBL).

Juist omdat lange tijd onduidelijk is geweest wat men onder eurhanasie zou moeten en willen verstaan, is het moeilijk om een moment aan te wijzen waarop in Nederland 'her' euthanasiedebat van start is gegaan. Een keuze voor een specifiek moment is betrekkelijk arbitrair en impliceert altijd een positiebepaling inzake begripskeuze en wat daarachter schuilgaat. Bovendien is er de keuze of het gaat over het debat onder experts of juist over het publieke debat. De geschiedenis van euthanasie, in de betekenis van een goede dood, gaat al eeuwen terug. ${ }^{3} \mathrm{Na}$ een vergelijking van de argumenten in het negentiende-eeuwse en 
vroeg twintigste-eeuwse debat over euthanasie in Engeland en Duitsland, concludeerde de ethicus Meerman dat deze weinig verschil tonen met recente debatten (Meerman 1991). Terwijl Meerman de aandacht vestigt op de continuïteit van de argumentatie, benadrukt de jurist Legemaate juist een breuk in het debat. Hij stelt dat het begin van een brede discussie over euthanasie zo rond 1973 ligt (Legemaate \& Dillmann 1998; Legemaate 1998b). In februari van dat jaar stond een Friese huisarts bij de rechtbank van Leeuwarden terecht voor 'euthanasie'. De huisarts had haar ernstig zieke moeder, op haar uitdrukkelijke verzoek, een dodelijke dosis morfine toegediend. Deze rechtszaak heeft in de media grote aandacht gekregen. De ethicus Zwart daarentegen legt het startpunt van de discussie over levensbeëindiging enkele jaren eerder. Hij beschouwt het in 1969 door de arts Van den Berg gepubliceerde boek over Medische macht en Medische Ethiek als aanzet voor de huidige discussie over levensbeëindiging (Zwart 1998). Zwart stelt dat Van den Berg in zijn boek een aantal begrippen heeft geïntroduceerd, zoals 'macht', 'grens' en 'zinvol/zinloos', die ook nu nog de medisch-ethische discussie over levensbeëindiging structureren. Zwart gaat zelfs verder en beschouwt Medische Macht en Medische Ethiek tevens als 'het eerste hoofdsruk van de huidige medische ethiek'.

In her licht van het hiervoor geschetste theoretische kader is een belangrijk criterium voor de opening van het debat over levensbeëindigend handelen, dat er sprake moet zijn van een fundamentele verandering in begrippen, probleemdefinities en/of de inmenging van nieuwe actoren in het debat. Dit is het geval in de periode eind jaren vijftig en begin jaren zestig. Het begin van de Nederlandse discussie over medische beslissingen rond het levenseinde moet dan ook niet in 1973 of 1969 , maar al eind jaren vijftig worden gelegd. Het boek van Van den Berg met daarin nieuwe begripsaanduidingen is dan ook meer als een resultaat of sluitstuk, dan als het begin van een bepaalde periode te beschouwen.

In de inleiding van dit hoofdstuk is aangeduid dat de opkomst van (technische) ontwikkelingen in de jaren vijftig en zestig een omslag inluidden in het denken over leven en dood in de geneeskunde. ${ }^{4}$ Het debat hierover kan, retrospectief, als voorloper voor discussies over levensbeëindigend handelen in een medische context worden gezien (Houtepen 1998: 120). Reanimatie of het stoppen van een reanimatiebehandeling waren niet het enige discussieonderwerp. In de discussies stonden onderhuids ook op het spel: de (medische) houding tegenover leven en dood, de waarheid vertellen aan het sterfbed, het staken dan wel instellen van een (reanimarie) behandeling, de rol van de arts en de aanvaardbaarheid van indirect dan wel direct doden. In 1959 schreef de neuroloogpsychiater Kooyman in het artsenblad Medisch Contact dat reanimatie behalve een 'aanwinst' ook een 'probleem en opgave' voor de geneeskunde was (Kooyman 1959). In het artikel ging hij in op de laatste twee aspecten. Kooyman constateerde dat door de mogelijkheid van reanimatie een 'impasse' kon ontstaan. 
'Een toestand van sterk gereduceerd bestaan, zonder vooruitgang, en in volledige afhankelijkheid van medisch-technische apparatuur en constante interventie'. In die toestand gingen 'verlengen en veraangenamen van het leven' volgens hem niet meer samen. Kooyman vroeg zich dan ook af hoe ver de medische bemoeienis bij dit soort gevallen zou moeten gaan en zag artsen voor een aantal lastige, 'medisch-ethische en juridische' vragen gesteld, 'met name of het inbepaalde-gevallen-nalaten van de reanimatie een verkapte euthanasie zou zijn, in hoeverre ouders of familie medezeggenschap hebben bij het bepalen van de ged ragslijn, en in hoeverre het een onrechtmatige daad is om bijvoorbeeld tegen de wil van de ouders of familie behandeling door te zetten' (Kooyman 1959: 442). Nieuwe onzekerheden dus, waarover een diversiteit aan meningen bestond en waarin volgens Kooyman vooralsnog 'de persoonlijke opvatting van de arts van beslissende betekenis' zou zijn. ${ }^{5} \mathrm{De}$ arts was dus wat hem betreft primair verantwoordelijk voor een oplossing in deze. Hij liet de vraag open wat de rol van de familie (ouders) hierin zou kunnen zijn. Kooyman besloot zijn artikel met de opmerking dat her afbreken van een eenmaal begonnen behandeling misschien wel euthanasie leek, maar dat er zijns inziens goede argumenten te geven waren om toch van verdere behandeling af te zien. Hij probeerde daarmee een onderscheid te maken tussen het zwaarbeladen en strafbare 'euthanasie' en de praktijk van de geneeskunde. ${ }^{6}$ In Kooyman's artikel komt de samenhang naar voren tussen de definitie van het probleem en de toebedeling van verantwoordelijkheden. Ten eerste werd het morele dilemma door hem onderscheiden van het strafbare euthanasie. Het ging hier volgens hem om het afbreken van een behandeling en dat kon volgens Kooyman niet op één lijn met euthanasie worden gesteld. Ten tweede stelde hij de vraag aan de orde wie hier nu recht van spreken had: mochten ouders of familie meebeslissen of was dit alleen aan de medicus? Hij besloot dat het in principe de medicus moest zijn die hierin een besluit nam. Ten derde legde Kooyman de aard van het issue op medisch-ethisch en medisch-juridisch terrein. Daarmee bakende hij af om wat voor soort vragen het hier volgens hem ging en opende hij de mogelijkheid van spreekrecht voor niet-artsen.

De medische professie ervaarde een nieuw soort kwesties; beslissingen in het schemergebied van de dood. Uit diverse artikelen die vanaf eind jaren vijftig zijn verschenen wordt duidelijk dat telkens naar ontwikkelingen in wetenschap en technologie wordt verwezen als oorzaak voor de nieuwe vragen. Niet alleen de medische professie boog zich over dit probleem. In 1956 werd al voorzichtig door een jurist zeggenschap hierover opgeëist. In een, door de eerder vermelde psychiater Kooyman aangehaalde voordracht aan de Vrije Universiteit over het thema 'Aspecten van de dood in de wetenschappen', wierp de hoogleraar recht Gerbrandy een aantal vragen op: kon in sommige gevallen toepassing van medische middelen niet misplaatst zijn? Was het opzettelijk niet toedienen van die 
middelen dan aangewezen? En stond het opzettelijk achterwege laten van levensduurverlenging, 'als omissiedelicr', nier gelijk aan opzettelijke verkorting van de levensduur? Hoewel hij geen pasklare antwoorden op deze vragen had, schaarde hij deze problemen niet onder 'het klassieke begrip levensberoving'. Gerbrandy deed in ieder geval een voorstel voor de aanpak van deze kwestie: 'Overleg tussen medicus en jurist schijnt hier aangewezen' (Kooyman 1960).

Hoe een dergelijke samenwerking er dan uit zou moeten zien was niet onmiddellijk duidelijk. De zeggenschap over dit soort kwesties was niet bij voorbaat een uitgemaakte zaak. Dat bleek uit een voordracht, gehouden op het congres in 1959 van de Koninklijke Nederlandsche Maatschappij tot bevordering der Geneeskunst, door de psychiater Rümke (Rümke 1959). De titel van de voordracht luidde: 'De dokter en het probleem van de dood'. Reanimatie en ook geriarrie dwongen de arts volgens de spreker om zich te buigen over het probleem van de dood. Artsen zouden dit 'van nature' niet geneigd zijn om te doen. Een arts had immers de opdracht om de dood te bestrijden en dacht daarom liever nier na over de dood. Iemand mer een andere expertise had hierin welliche meer kennis zaken. De moraaltheoloog bijvoorbeeld stond anders tegenover de dood en 'de dokter voelt zelfs dikwijls in de geestelijke bijna zijn vijand, de geestelijke, die de dood niet ziet als iets dat bestreden moet worden'. Rümke vroeg dus bij zijn collega's aandacht voor het probleem van de dood. Artscn zouden actief mee moeten denken in deze materie, want hij benadrukte: 'de parient is van ons' (Rümke 1959: 2097). Met deze claim gaf Rümke zowel naar zijn collega's als narar andere betrokkenen cen duidelijk signaal af. De dood was altijd een grote tegenstander van de arts geweest. Nieuwe ontwikkelingen leken de arts nu tot een andere gezichtsbepaling te dwingen, waarbij zeggenschap hierover door anderen niet ondenkbaar was.

Aan het voorstel van de jurist Gerbrandy voor samenwerking tussen artsen en juristen werd al in 1959 gehoor gegeven. In oktober van dat jaar belegde de Utrechtse Advocatenvereniging een vergadering over de vragen rond reanimatie. Als sprekers traden op de reeds genoemde neuroloog-psychiater Kooyman en de procureur generaal bij de Hoge Raad der Nederlanden, Langemeijer. Beide voordrachten werden in het artsenblad Medisch Contact gepubliceerd. Kooyman stelde dat vele vragen rondom de gerezen problematiek misschien wel meer op filosofisch terrein dan op strikt medisch of juridisch terrein lagen. Hij wees in dit verband op het 'gebrek aan wijsgerige verdieping' bij artsen. Niettemin verwachttc hij van de jurist Langemeijer 'opheldering van de verwarring waarin menig arts' zich in deze materie bevond (Kooyman I960: I87). Met name ten aanzien van de vraag of artikel 293 (levensberoving op verzoek) en 294 (hilpen bij zelfnoord) Wethoek van Strafrecht van toepassing waren op het afzien van of stoppen met reanimeren. In zijn voordracht benadrukte Langemeijer dat vragen rond reanimatie samenhingen met euthanasie, maar 
dat er genoeg redenen waren te geven om deze twee afzonderlijk te behandelen. Bijvoorbeeld het feit dat toen de wetgever artikel 293 van het Wetboek van Strafrecht maakte de huidige situatie wat betreft reanimatie 'volkomen onvoorstelbaar' was (Langemeijer 1960). Voor zover hem bekend was er ook alleen maar juridische literatuur over het euthanasievraagstuk, vóórdat het probleem van de reanimatie acuut werd. Daarmee waren de vragen over reanimatie dus een nieuw vraagstuk geworden, zowel voor de arts als voor de jurist. Langemeijer was niet bevreesd om zijn vingers aan dit vraagstuk te branden. Hij was van mening dat 'wanneer de dokter in een geval, waarin de reanimatie hopeloos is, (...) de reanimatie staakt, dit iets is dat zo volstrekt buiten de gezichtskring van de wetgever ligt, (...) dat het daar eenvoudig niet onder valt'. Daarom vond hij dat 'de Strafwer hier bepaald geen verbod inhoudt en dat daarom de medicus zich hier inderdaad vrij mag voelen om te handelen; niet naar willekeur natuurlijk, maar naar zijn geweten, voorgelicht door zijn beste medische inzicht' (Langemeijer 1960: 190). ${ }^{7}$ Hoewel juristen over dit onderwerp dus wel iets zinnigs te zeggen hadden gaf Langemeijer de beslissingsmacht uiteindelijk (terug) aan de arts; het ging om een professioneel gewetensprobleem van de arts. ${ }^{8} \mathrm{Het}$ probleem in kwestie leek dus voorlopig een gezamenlijk probleem van de medicus en de jurist te zijn, waarbij de medicus uiteindelijk de politieke verantwoordelijkheid kreeg toebedeeld; het was zijn persoonlijke beslissing op geleide van professionele afwegingen.

\section{Afzien van of ophouden met medische behandeling?}

De nieuwe onzekerheden en vragen in de praktijk van de geneeskunde, als gevolg van reanimatie en beademingstechnieken, betekenden grote aandacht voor het grijze gebied tussen leven en dood. ${ }^{2}$ De diagnose van de dood was onzeker. Zo beaamde de arts Stolte: 'Een betrouwbaar vroeg verschijnsel van de dood kennen we niet.' Niet alleen de dood was onzeker, de mogelijkheden van reanimatie- en beademingstechnieken riepen ook nieuwe vragen op over de status van de zieke (patiënt). Dat betekende eveneens nieuwe onzekerheid: 'Is hier sprake van een levend mens of hebben we te maken met een uitgebreid "hartlong-preparaat" waaraan de ziel reeds lang ontvloden is? Wanneer gaat de schijndood in werkelijke dood over?' (Stolte 1960: 87). Deze onzekerheid riep nieuwe vragen op met betrekking tot behandeling. Tor hoever was een arts verplicht om door te gaan met behandelen in zo'n geval? Indien de circulatie na reanimatie weer op gang was gekomen, maar het bewustzijn nog niet was teruggekeerd, was het dan geoorloofd om de apparaten uit te schakelen?

In okrober 1963 hield de hoogleraar heelkunde Den Otter een voordracht op de algemene ledenvergadering van de Protestants-Christelijke artsenorganisatic en ging in op bovenstaande vragen. De vragen en onzekerheden zijn een 
indicatie van de niche die ontstond. Uit de voordracht van Den Otter werd duidelijk dat zich op dit terrein een potentiële professiestrijd kon ontketenen. Den Otter constateerde dat er inderdaad nog grote onzekerheid bestond over de vraag wanneer men met reanimatie moest beginnen en wanneer je er mee op moest houden. Dat wilde niet meteen zeggen dat de medische professie hierbij hulp nodig had van buitenstaanders. Hij vond dit een vraagstuk dat exclusief bij de medische professie behoorde te liggen. Den Otter stelde dat men zich in dit soort gevallen namelijk vaak ' tot de autoriteit van de kerk, tot de filosofie of tot gerechtelijke instanties om leiding en advies' wendde. Daarnaast hoorde hij links en rechts de roep om nieuwe medisch-ethische richtlijnen 'waarin de problemen om de kunstmatige verlenging van het leven opgelost worden door voorschriften die de geplaagde consciëntie enigermate houvast bieden.' (Den Otter 1963: 183). Zelfwas hij er echter vast van overtuigd dat er geen behoefte was aan een nieuwe medische ethiek 'en nog veel minder noodzaak tor discussies met ontdane en verontruste theologen, filosofen en juristen. Integendeel: ik meen dat het initiatief van de geneeskunde zelf moet uitgaan' (p. I83). Den Otter zat niet op goedbedoelde adviezen van buitenstaanders te wachten, hij was van mening dat de medische professie heel goed zélf tot een oplossing voor de gerezen problemen kon komen.

Die adviezen werden desondanks wel gepubliceerd in de diverse artsenbladen. De katholieke moraaltheoloog Sporken werkte de vraag - levensverlenging of niet - verder uit in een artikel dat in het Rooms-Katholieke Artsenblad verscheen (Sporken 1965a). Voor de uitwerking van deze vraag koos hij de ethische invalshoek. Sporken hanteerde een filosofisch-antropologische visie op ethiek. Hij vroeg zich af hoe het denken over menselijk leven en ethische consequenties van medisch handelen ingezet kon worden bij de beantwoording van vragen over levensverlenging. Hij kwam tot de conclusie dat het criterium voor de zin en het ethisch goed zijn van medisch handelen bestond uit de vraag: 'wordt door deze behandeling werkelijk een dienst bewezen aan deze mens, die - tezamen met zijn medemensen - op weg is naar zijn eindbestemming overeenkomstig Gods roeping?' (p. 377). Dit kwam neer op de vraag of de patiënt van behandeling inderdaad beter werd als mens. Het 'mens-zijn' werd door Sporken dus levensbeschouwelijk ingevuld. Sporken was van mening dat de algemene ethische norm van 'eerbied voor het leven' bij dergelijke gecompliceerde problemen niet volstond en achtte nadere concretisering dan ook noodzakelijk. Arts en patiënt zouden hier samen over moeten beslissen en de arts moest de patiënt in zijn totaliteit als mens-zijn bezien en niet als uitsluitend biologisch (of psychisch) leven. Sporken voegde een nieuw element aan de probleemdefinitie toe: de patiënt werd ten tonele gevoerd inzake beslissingen rond leven en dood. Volgens Sporken zou een arts hier niet alleen in moeten beslissen, in tegenstelling tot de conclusie van de juristen en medici uit de vorige 
paragraaf. Voor hem gold dus de normatieve leidraad voor het handelen van een arts - het principe van absoluut respect voor het menselijk leven - niet in álle gevallen.

De absolute interpretatie van het respect voor het menselijk leven, dat eeuwenlang de leidraad was bij medisch handelen, stond dus vanuit verschillende invalshoeken - medisch (Kooyman), juridisch (Langemeijer) en ethisch (Sporken) ter discussie. De gangbare medische ethiek was in beroering, of zoals de redactie van de bundel Recent Medisch Ethisch Denken $\mathrm{I}$ het uitdrukte: er is sprake van een evolutie - 'men mag wel zeggen revolutie' - in het medisch ethisch denken (Kortbeek 1968). Dit boek, verschenen in een medische reeks, wilde een actuele stand van zaken weergeven over diverse onderwerpen. Opvallend is dat kwesties rond verlenging van het leven en verkorting van het leven het meest in de belangstelling stonden. Minstens vier van de elf hoofdstukken had hier direct betrekking op. Op twee hoofdstukken na, van de jurist Rang en de ethicus Heering, waren alle bijdragen overigens door artsen geHschreven. De arts Marlet constateerde dat de oorspronkelijke betekenis van het begrip euthanasie aan reikwijdte had ingeboet en verwees voor één van de engere definities die in gebruik waren naar her in 1960 verschenen boek van de huisarts en historicus Lindeboom over 'Medische Ethiek' (Marlet 1969). De eerder genoemde Stolte, bijzonder hoogleraar ziekenhuiswetenschappen aan de Katholieke Hogeschool Tilburg en Katholieke Universiteit Nijmegen, ging in op het probleem van de kunstmatige levensverlenging. Hij gaf in zijn bijdrage de verhoudingen weer tussen de verschillende disciplines in dit vraagstuk. Stolte zag de vraag van her al dan nier kunstmatig verlengen van her leven als een dilemma van 'plichten van de arts'. Aan de ene kant moest een arts zich inzetten voor het leven en de gezondheid van de patiënt, aan de andere kant was het zijn plicht om het lijden te verzachten en niet te verlengen. Daarbij raadde Stolte artsen wel aan om 'dergelijke beslissingen' pas te nemen 'na overleg met terzake deskundige collegae'. Maar de 'uiteindelijke beslissing ligt echter bij de behandelende arts, die, in opdracht van de patiënt (...) zal moeten trachten te doen, wat (...) de meest juiste handelwijze lijkt' (Stolte 1968: 144). Hij definieerde dit vraagstuk dus als een artsenprobleem. Want 'Raadplegen van de patiënt (...) of van de familieleden is vrijwel nooit mogelijk' (p. I4I). Soms moest er hulp van buiten komen en kon het recht nog een rol spelen. In geval van twijfel moesten namelijk 'de feitelijke omstandigheden en het recht zoveel mogelijk de weg wijzen' (p. I42). Hij haalde hierbij de eerder genoemde jurist Langemeijer aan, die had aangegeven dat het staken van een hopeloze reanimatiepoging géén misdrijf tegen het leven was. Stolte noemde zelfs in het geval van een terminaal coma de 'voortzetring van de beademing niet alleen zinloos, maar onjuist, omdat het zonder uitzicht op verbetering het stervensproces rekt' (p. 143). In die gevallen zou sprake zijn van 'verlenging van het lijden'. Voor dit soort patiënten zou het 
'recht om te sterven' gerespecteerd moeten worden. Stolte introduceerde dus het begrip 'recht' om de zijns inziens in sommige gevallen zinloze en onjuiste stervensverlenging een halt toe te roepen. Daarnaast wees Stolte op de veranderlijke aard van dit soort kwesties. 'Moralisten zeggen, dat de arts, (...) dat moet doen wat zijn kunst hem naar de standaard van de professie voorschrijft. Daarom zal de professie zich relkens weer opnieuw over deze en dergelijke vraagstukken hebben te beraden om door geëigende voorlichting de professieleden de weg te wijzen' (p. I44). Ethici hadden hierin dus een marginale rol; het bleef een probleem van de professie. Doordat Stolte de kwestie opvatte als een probleem van het verlengde lijden en het de plicht was van een arts om het lijden te verzachten, was en bleef het dus in zijn optiek een probleem van medische professie.

Er leek in grote mate consensus te zijn in de discussie wat betreft de constatering dat ontwikkelingen in de geneeskunde de arts voor nieuwe dilemma's en beslissingen hadden geplaatst. Deze medisch-technologische ontwikkelingen zouden een andere houding van de arts vragen. Daarom deed de neuroloog Prick in 1969 een voorstel om het takenpakket van artsen opnieuw te formuleren. In het artsenblad Medisch Contact ontspon zich vervolgens een discussie over 'medische ethiek met betrekking tot de nieuwste ontwikkelingen in de geneeskunde'. Prick kaderde het voor vele doeleinden gebruikte begrip 'euthanasie' af van een aantal andere medische handelingen. Zo stelde hij dat het 'staken van buitengewone middelen' waardoor de dood intrad, geen euthanasie was, omdat de patiënt toch al zou zijn overleden als het middel niet zou zijn toegepast. En ook wat wij nu de leer van het dubbele effect noemen, het toedienen van pijnstillers met als neveneffect levensbekorting, definieerde Prick niet als euthanasie. Hij sprak in dat geval over 'coïncidentele levensverkorting'. Door onderscheid te maken tussen verschillende soorten medische handelingen en her strafbare eurhanasie kon Prick zijn voorstel legitimeren om het takenpakket van artsen te veranderen. Kort samengevat kwam zijn voorstel neer op her volgende: I) het leven behouden, daar waar dat zinvol is; 2 ) het lijden verzachten; 3) het begeleiden van het sterven (Prick 1969b). Deze 'nieuwe taken' van de arts riepen een felle reactie op van de jurist Goudsmit. Hij vreesde namelijk voor een hellend vlak indien 'minder scrupuleuze artsen' zich deze nieuwe regels zouden gaan aanmeten. Goudsmit hield daarom onverkort vast aan de norm absolute eerbied voor het leven. Hij vond dat een arts noch door doen, noch door nalaten (zoals Prick voorstelde) de 'dood naderbij mag brengen' (Goudsmit 1969). In een korte reactie hierop gaf Prick aan niet te geloven in een dergelijke 'onveranderde starre medische ethiek' (Prick 1969a). Hij werd daarin gesteund door een aantal collega's. In het artsenblad Medisch Contact klonken meerdere stemmen van artsen die een flexibele ethiek bepleitten (Van Mechelen 1969; Wierdsma 1969). 


\section{Medische macht}

De psychiater Van den Berg vertaalde een groot deel van de voorgaande geluiden in een beeldende publicatie: Medische Macht en Medische Ethiek (Van den Berg 1969). Zijn betoog voor een nieuwe ethiek, geschreven in een kordate stijl en geïllustreerd met schokkende foto's, had het effect van een steen in de vijver. De toegenomen mogelijkheden in de geneeskunde waar iedereen naar verwees als oorzaak voor de nieuwe problemen, duidde Van den Berg aan met het begrip: 'medische macht'. Dit was de 'technische macht van de huidige arts', voortgekomen uit de nieuwe geneeskunde. Deze technische macht was volgens hem teveel gefixeerd op doorbehandelen (als beslissing van de arts). Hij gebruikte de woorden 'slachtoffers van de medisch-technische macht' om aan te geven dat er sprake was van een misstand en pleitte voor een wet van de medische macht, waarbij openheid voorop stond (p. 27). Van den Berg introduceerde de patiënt nadrukkelijk als gesprekspartner. Daarmee distantieerde hij zich van de gangbare medische invalshoek. De patiënt had volgens hem het recht om te horen waar hij aan toe was. De arts, die zich ondanks de nieuwe 'technische macht' nog steeds in 'een oud zwijgen' hulde, moest gaan praten (Van den Berg 1969: 43). Waar collega-artsen een overleg met de familie c.q. patiënt als optie openhielden en Sporken de patiënt in de beslissing betrok, ging Van den Berg één stap verder en gaf hem zelfs her recht op informatie. Hij wilde het zwijgen van de arts (de medische macht) doorbreken door de incroductie van een 'nieuwe ethiek'. Een nieuwe ethiek die paste bij de nieuwe medische macht. Hieraan verbond hij een pleidooi voor zowel passieve als actieve levensbeëindiging, want zijn nieuwe ethiek luidde: 'Mcnselijk leven mag, door de arts, beëindigd worden. Op twee manieren. Door medisch handelen te staken, en door een medische handeling te verrichten. In her eerste geval is de arrs passief. (...). In het tweede geval is de arts actief. Hij doodt de patiënt' (Van den Berg 1969: 48). Van den Berg introduceerde dus een nieuwe, radicale regel. Mer deze stelling nam hij radicaal afscheid van het principe van absoluut respect voor menselijk leven, dat door onder andere Kooyman, Langemeijer en Sporken in de vorige paragraaf ter discussie was gesteld en door Goudsmit verdedigd. Hij legde de beslissingsverantwoordelijkheid bij de arts en familie. Zij zouden gezamenlijk een beslissing moeten nemen, maar alleen de arts was uiteindelijk verantwoordelijk voor de uitvoering. Her boekje bleek een enorm succes te zijn en werd vele malen herdrukt.

In een recensie van dit boek stemde de arts-jurist Schuurmans Stekhoven verheugd in met Van den Bergs pleidooi dat hij weergaf in termen van passieve euthanasie ('nalaten van levensverlengende behandeling'), en actieve euthanasie ('de rechtstreeks dodende injectic') en hanteerde daarbij probleemloos de term euthanasie. Schuurmans Stekhoven borduurde voort op de aanklacht 
tegen de medische macht die Van den Berg had ingezet. Hij wilde 'aan die medisch-ethische veroordeling een medisch-juridische veroordeling toevoegen; ik acht een en ander "onrechtmatig", dus in strijd met de rechtsbedeling' (Schuurmans Stekhoven 1969a: 1358). Het was 'namelijk in strijd met de "rechten van de mens" iemand te beletten zijn natuurlijke dood te sterven...'. Als er geen 'persoonlijkheid (geen mens) meer bestaat dan is de patiënt juridisch overleden...' (p. 1358). Schuurmans Stekhoven definieerde de situatie dus in termen van het verhinderen van een natuurlijke dood. Hij benadrukte daarmee het gevolg dat voortvloeide uit de stelling van de arts Stolte uit de vorige paragraaf: het verlengde lijden. Met dien verstande dat Schuurmans Stekhoven dit gevolg vertaalde en versterkte: het lijden verlengen betekende het sterven verhinderen. Als in dat soort situaties wel werd doorgegaan met behandeling, zo stelde Schuurmans Stekhoven dan "kom ik als jurist tot het vonnis "misbruik van de medisch-technische machr", "misbruik van bevoegdheid"' (p. 1358). Hij was er niet voor bevreesd om medici nog 'veel meer te zullen [laten] schrikken dan van de kwalificaties van Van den Berg'. Hij noemde deze situaties namelijk 'mishandeling' in het kader van het misdrijf strafbaar gesteld door artikel 300 van het Wetboek van Strafrecht. In tegenstelling tot Van den Berg, raadde Schuurmans Stekhoven zijn medische collega's wél aan om tot een nadere bepaling van de grens tussen zinvol en zinloos leven te komen. Hij wilde zelf wel enige lijnen trekken in dit 'uiterst subtiele medisch-ethische (= zedelijke) en medischjuridische (= civiel- en strafrechtelijke) probleem'. Hij bracht hierin zelfs een hiërarchie aan. Het recht was volgens hem 'bij de bepaling van de grens tussen leven en dood veel belangrijker dan de ethiek'. Omdat het probleem van al dan niet stoppen met beademen volgens hem een 'administratiefrechtelijk overlijdensregistratie-vraagstuk' was, waarbij het niet om de eerbied voor het leven, maar om de eerbied voor de dood zou gaan. Schuurmans Stekhoven claimde hier overduidelijk een juridische context voor de materie.

Ook Sporken gaf een reactie op het boekje van Van den Berg. Hij was het mer diens stellingen eens voorzover 'de werkelijke belangen van de patiënt' het uitgangspunt en de grondnorm vormden van het medisch handelen. Sporken zette de mens achter de patiënt centraal. Dialoog en overleg tussen arts en patiënt waren voor hem van groot belang, waarbij 'het laatste en beslissende woord uiteindelijk aan de patiënt toekomt' (Sporken 1969a: 1432). Hiermee kende hij een zwaar gewicht toe aan de rol van de patiënt. In de gangbare geluiden was het namelijk de arts die besliste, eventueel in samenspraak met de patiënt en/of familie. Toch verbond Sporken hier amper professieclaims aan voor de ethiek, zoals Schuurmans Stekhoven dit voor het recht wel deed. Sporken herhaalde nog maar eens dat bezinning op de vraag wat zinvol en acceptabel menselijk leven betekent nodig was. En hij was het dan ook niet eens met Van den Bergs conclusie dat de arts het recht en of zelfs de plicht had om te doden in 
sommige gevallen. Als criteria voor zinvol of menselijk leven stelde Sporken voor: de mogelijkheid van de patiënt zelf om er zin aan te geven, of diegene nog een bepaalde taak te vervullen had en tenslotte de sociale dimensie. Terwijl anderen, op verschillende wijzen, het staken van zinloos handelen als 'legitieme' medische handeling losweekten uit de problematiek, leek het Sporken onmogelijk om hierin een absoluut standpunt in te nemen. Hij hield het issue juist als één geheel bij elkaar. Voor wat zijn vakgebied betreft zag hij daarin een reflexieve rol weggelegd. Hij meende dat 'medische ethiek van de toekomst noodzakelijk cultuurkritiek dient te zijn. Medische ethiek bedoelt immers te zijn: een kritische reflexie op het medisch ethos, de poging door te dringen tot het mensbegrip, dat zich in die concrete normen van het ethos manifesteert, dit kritisch toetsend op zijn authenticiteit' (Sporken 1969a: 1434).

Deze opvatting verwoordde hij ook bij zijn tegelijkertijd verschenen handboek medische ethiek Voorlopige diagnose (Sporken 1969b). Dit boek wilde een soort overgangsboek zijn tussen de verouderde handboeken voor medische ethiek en een 'definitieve' eigentijdse medische ethiek. Sporken gaf daarin een diagnose van medische ethiek aan het einde van de jaren zestig. Ten aanzien van het probleem van de levensbekorting stelde hij dat het bijna onmogelijk was om een wezenlijk onderscheid te maken tussen ophouden met levensverlenging, pijnbestrijding die tegelijkertijd tot de dood zou leiden, passieve euthanasie (kunstmatige levensverlenging niet meer continueren) en actieve euthanasie. Sporken stelde het opzettelijk nalaten van een levensreddende daad ethisch gelijk aan een levensbenemende daad (Sporken 1969b: 22I). Tussen het toedienen van een overmatige dosis pijnstillende middelen en het toedienen van een nog iers grotere dosis zag hij slechts een gradueel verschil. Een 'categorische en voor alle situaties geldende ethische veroordeling van euthanasie' was voor Sporken dan ook onhoudbaar. Niettemin leek hem legalisering van de actieve euthanasie nog te vroeg, want: 'Het recht volgt de ethiek en de ethiek is inzake euthanasie nog lang niet aan een definitief standpunt toe' (Sporken 1969b: 225). $\mathrm{Nu}$ bakende Sporken, ner als Schuurmans Stekhoven, wel het domein van zijn vakgebied nader af in de discussie over levensbeëindigend handelen. Zette Schuurmans Stekhoven het recht voorop, door Sporken werd de ethiek als primair beschouwd. Deze ordening in prioriteit, van welk vakgebied eerst zeggenschap heeft, is een vorm van afbakening en jurisdictie.

In de jaren vijftig en zestig werden vragen omtrent het aanvangen dan wel afbreken van een reanimatiepoging door zowel artsen, juristen als ethici als nieuw aangemerkt. Tot dan toe was men altijd uitgegaan van 'het leven verlengen', op grond van het principe van absoluut respect voor menselijk leven. Het ontstaan van een schemergebied tussen leven en dood maakte dat deze richtlijn geen duidelijkheid meer bood. Door nagenoeg alle actoren in het debat werden de technologische ontwikkelingen in de geneeskunde aangewezen als oorzaak 
voor de nicuwe vragen en onzekerheden op dit terrein. Er werd een niche gecreëerd. L) nieuwe rctoriek van her 'inperken van de medische machr' bleek vervolgens grote aantrekkingskracht te hebben. In eerste instantie leek het debat zich vooral tussen artsen onderling en tussen artsen en juristen te ontspinnen. Z.ij gingen over het beheer van het probleem. Ethici gaven vanuit de zijlijn hun reflectie. In het debat over vragen rond het levenseinde werd door de actoren gesproken in termen van misbruik van de medische macht en over patiënren als slachtoffers van de medische macht. Er werden pogingen gedaan om het staken van een reanimatie los te koppelen van euthanasie in de zin van art. 293 van het Wetboek van Strafrecht. Juristen duidden de nieuwe toestand van sommige patiënten niet meer als leven aan en verklaarden de patiënt zelfs juridisch dood. Zij kregen gedurende het debat voor een deel de eigendom over het probleem toebedeeld en hebben deze ook verworven. Artsen werden als uiteindelijk verantwoordelijk beschouwd voor het probleem; de beslissing lag bij de individuele arts. Slechts een paar artsen liet ruimte over om ook de patiënt en/of familie er in te betrekken. Diverse artsen pleitten voor nieuwe bevoegdheden voor de arts, terwijl vanuit de ethick juist aan de patiënt het laatste en beslissende woord werd toegekend. De vraag luidde of een patiënt wel werkelijk beter werd van een behandeling. Terwijl artsen en juristen op meerdere punten op één lijn leken te zitten, waren er vanuit ethiek dus tegengestelde geluiden te horen. In elk geval geluiden die niet harmonieus binnen het debat vielen.

\section{'Schijngestalten' van euthanasie}

\section{Zeggenschap over medisch-ethische vragin}

De thema's 'actieve levensbeëindiging' en 'arts-patiënt relatie', die Van den Berg op de agenda zette, hadden grote aantrekkingskracht. ${ }^{10}$ Er heerste een algehele crisisstemming, in de zin van een omslag in het denken, met betrekking tot de medische ethiek. Deze crisis werd gevoed door een grote hoeveelheid literatuur waarin over een evolutie in het medisch-ethisch denken werd gesproken. Ook werden alternatieven voorgesteld voor de Hippocratische regel van absoluut respect voor het menselijk leven, bijvoorbeeld zinvol leven of zinvol handelen. Door het issue in deze termen te gieten werd er tegelijkertijd zeggenschap geclaimd met betrekking tor het probleem. Het antwoord op de vraag van wie het probleem was veranderde telkens. In deze paragraaf wordt duidelijk hoe het euthanasieprobleem in de jaren zeventig verkaveld raakte, doordat men verschillende onderscheidingen in het begrip aanbracht. Deze onderscheidingen variëren van vrijwillig en niet vrijwillig, actief en passief tot direct en indirect. De verschillende onderscheidingen in het probleem hadden gevolgen voor wie 
verantwoordelijk werd geacht. Met de niche die ontstond was er ruimte voor verschillende opvattingen. Zo zou passieve euthanasie volgens sommigen wel als onderdeel van het medisch handelen zijn toegestaan, maar actieve euthanasie nier. Hetzelfde zou voor vrijwillige en onvrijwillige euthanasie gelden. In de argumenten pro en contra wordt duidelijk dat ethici en juristen (onderling zowel als met elkaar) hierover van mening verschillen. Er ontstond cen debat over verschillende manieren om om te gaan met de (coencmende) medische macht, die algemeen als oorzaak voor de crisis binnen de medische ethiek werd beschouwd.

Begin jaren zeventig was niet duidelijk wie wat over ethiek en eurhanasie kon of mocht zeggen. De 'eigendom' van euthanasie en medische ethiek was omstreden. Dat bleek uit de onmacht van de KNMG om met deze problemen om te gaan en de druk die door niet-artsen werd uitgeoefend om zich in de crisis te mengen. Tijdens de Algemene Vergadering in 1970 stond de medische ethick bovenaan op de agenda. De voorzitter van de KNMG, Van der Drift, wees tijdens de opening van de vergadering op de 'evolutie' in her medisch-ethisch denken. Hij besloot zijn inleiding mer de woorden: 'De tijd is voorbij dat de medische ethiek de schijn kon wekken een gcheimleer te zijn dic bchoorde tor de essentialia van het groepsgeheim der medici' (Van der Drift 1970: 417). De fase warin een dialoog met de 'buitenwereld' nog optioneel was, was dus verstreken (Van Mechelen 1970). De medische wereld kon er niet meer onderuit rekenschap re geven van haar ethische doen en laten. Daarmee werd de deur van zeggenschap over medische ethiek officieel op een kier gezer. In de context van het kunstmatig in leven houden van mensen met ernstige uitval van centrale functies wees Van der Drift op het onvermogen van het principe 'eerbied voor het leven'. Hij schaafde de scherpe kantjes hiervan af door dit principe te reduceren van 'oplossing van alle problemen' tot 'basis voor een juiste probleemstelling' (Van der Drift 1970). Er moest een nieuwe aanpak van de medische ethiek in het algemeen komen. "Het dagelijks bestuur van de kNMG ging daartoe uit van een 'pluriforme medische ethiek en de wenselijkheid van een mulridisciplinaire bestudering der onderhavige vraagstukken'. Daartoe werd een werkgroep gevormd. ${ }^{12}$ Men wilde af van het idee van medische ethiek als een boekje met vaste gedragscodes. Bovendien wenste men een splitsing tussen grondslagen van de medische ethiek en de fatsoensregels (in het zogenoemde 'blauwe boekje' uit 1959: Medische Ethiek en Gedragsleer, nog een vaste combinatie) (Roelink 1971). Er moest meer continuïteit komen en daarom werd aan losbladige capita selecta van de hand van verschillende deskundigen gedacht. Hiermee zou een pluriforme en actuele benadering gewaarborgd moeten zijn.

Voor de genoemde vergadering was een 'buitenstaander', de ethicus Sporken, uitgenodigd om een voordracht te houden over medische ethiek. Sporken schetste bij deze gelegenheid (nogmaals) de evolutie die zich voltrok in het 
medisch-ethisch denken. Hij zag daarin een heropbouw van de fundamentele medische ethiek met duidelijke kenmerken van een medisch-sociale ethiek en duidde dat aan met de woorden 'de humanisering van het medisch handelen' (Sporken 1970a). Dit als antwoord op het feit dat volgens hem 'de medische wetenschap (en ten dele ook de medische praktijk) zodanig in de ban geraakt [is] van dit natuurwetenschappelijke, dat het subject, waarop de medische hulp gericht is, tot object werd' (Sporken 1970a: 16I). Hij pleitte er dan ook voor dat meer aandacht zou worden besteed aan antropologie en medische ethiek in de medische opleiding, bijvoorbeeld aan de hand van stervenshulp. Dat betekende zijns inziens het bespreekbaar maken van de dodelijke afloop van een ziekte en de gevoelens van angst en eenzaamheid die daarmee gepaard gingen, alsmede het aangaan van een werkelijke dialoog met de zieke. Hij was van mening dat: 'stervensbegeleiding een der testcases is, naar aanleiding waarvan wij concreet kunnen nagaan hoe onze medische ethiek er voorstaat: de personalistische en sociale aspecten kunnen hierbij als wezenlijk medenormerend naar voren komen' (Sporken 1970: 423). Op de vraag wiens taak het was de stervensbegeleiding te verzorgen had Sporken geen pasklaar antwoord. Hij hield de mogelijkheid open dat daar 'voor de pastor een ongelooflijk goede taak is weggelegd' (Hoofdbestuur 1970: 962). Daarmee vormde Sporken natuurlijk een gevaar voor de zeggenschap van artsen in deze. Door de stervensbegeleiding op deze manier op de medisch-ethische agenda te zetten bakende Sporken een bepaald aspect van de kwestie af; hij zette het sociale en menselijke aspect centraal. Hij zag dit ook als een antwoord op de toenemende medische macht: euthanasie als één mogelijke manier waarop stervenshulp gerealiseerd zou kunnen worden (Sporken 1977). Volgens hem was een juiste beantwoording van de euthanasievraag slechts mogelijk binnen een dergelijk breder kader. In zijn tweede handboek medische ethiek pleitte Sporken voor een groter gebied van de medische ethiek (i.c. ethiek van de gezondheidszorg) en betoogde dat er een dubbele schaalvergroting zou moeten plaatsvinden: r) de verantwoordelijkheid van de gezondheidszorg moest breder gedragen worden en niet meer alleen op de schouders van arts en patiënt liggen. Ook de overheid en het 'medisch systeem' moesten hierin een rol gaan krijgen 2) de ethische reflectie moest zich niet meer beperken tot ethische vragen uit de arts-patiëntrelatie, maar zich uitstrekken tot het gebied van de gehele gezondheid, gezondheidszorg en het gezondheidszorgsysteem, het leefmilieu en het overheidsbeleid inzake gezondheidszorg (Sporken 1977).

De filosoof Klever ging een stap verder dan Sporken. Hield Sporken het er nog voorzichtig op dat in de stervensbegeleiding wellicht een taak voor de pastor was weggelegd, Klever stelde simpelweg de vraag of een arts de euthanasie zou moeten uitvoeren ter discussie. Hij zag dit als een puur technische kwestie, vergelijkbaar met het uitbesteden van bepaalde taken aan specialisten. 'Er lijkt 
geen enkel ethisch bezwaar te bestaan, de uitvoering van een suïcide-besluit, liever gezegd van de kunstmatige vormgeving van zijn dood, aan iemand anders toe te vertrouwen. Waarom zou men ook hier niet mogen "uitbesteden"?" (Klever 1972: 303). Vanuit ethische zijde werden dus ideeën naar voren gebracht die wel bedreigend, redenerend vanuit de gedachte dat zij hier zeggenschap over zouden willen houden of krijgen, voor de medische professie konden overkomen. Hoewel op dat moment de zaak nog open lag, kan achteraf worden vastgesteld dat dit geen geluiden waren die een bondgenoorschap tussen mer artsen aannemelijk maakten.

In 1973 had een speciale werkgroep van de KNMG een rapport over euthanasie gereed. ${ }^{13}$ Deze nota werd echter door het hoofdbestuur afgewezen, omdat ze te 'liberaal' zou zijn. De nota week namelijk af van de reactie van het hoofdbestuur op her interim-advies van de Gezondheidsraad. De beperking 'bij een ongeneeslijk zieke patiënt', evenals de hierop door het hoofdbestuur aangebrachte aanscherping 'indien de stervensfase is ingetreden', werden door de werkgroep uit de definitie van euthanasie gelaten. ${ }^{14}$ Binnen de medische professie bleek dus geen consensus te zijn over hoe euthanasie als probleem nu vorm zou moeten worden gegeven. Een jaar later besloot het hoofdbestuur echter alsnog om de discussienota te publiceren. Enerzijds vanwege de vele verzoeken hiertoe van leden en regionale afdelingen, anderzijds omdat het rapport tot de dagbladpers was doorgedrongen (Commentaar 1975). Begin 1975 verscheen de discussienota dus alsnog in het artsenblad Medisch Contact (KNMG 1975). Uit de nota bleek een worsteling van de werkgroep met de medische ethiek. Aan de ene kant werd gepleit voor een dynamische ethiek. Aan de andere kant was men beducht voor het 'openbreken van de medische beroepscode', omdat dat een 'gevaarlijke porte d'entrée voor manipulatie door de overheid' zou zijn (KNMG 1975: 14). Er werd gevreesd voor een ethiek die in toenemende mate zou worden bepaald door socio-economische en politieke vragen. Het zou nog een graad erger zijn als artsen een ethiek opgelegdzouden krijgen. 'Hebben niet vele artsen dit gevoel gehad, toen van overheidswege de abortus op zeer ruime indicatie werd toegestaan?' (KNMG 1975: 14). Een herhaling van zetten zoals in het abortusdebat moest dus te allen tijde voorkomen worden. Uit de nota werd duidelijk dat volgens de KNMG werkgroep het probleem van de nieuwe medische macht en de medische erhiek inzake eurhanasic (nog steeds) een artsenprobleem was. Een artsenprobleem waarover de KNMG zelf de regie wilde houden.

De moraaltheologe Terborgh-Dupuis was het daar volstrekt niet mee eens. Zij stelde in haar proefschrift het thema 'crisis in de medische ethiek' centraal (Terborgh-Dupuis 1976). Volgens Dupuis was medische ethiek geen exclusief terrein meer voor alleen de medische professie, maar veeleer een aangelegenheid die meer mensen aanging. Dupuis zette het 'indringende karakter' van het issue in bij haar argumentatie. Vanwege de grote invloed op de 'persoonlijke be- 
staanswijze' vond zij dat medische ethiek niet slechts een zaak van artsen kon en mocht zijn, maar een zaak van allen.

De juriste Van Till signaleerde reeds begin jaren zeventig dat de bestaande medische erhiek geen voldoende leidraad meer bood om op de gerezen medische problemen antwoord te geven. Dat was volgens haar ook nier zo verwonderlijk, omdat medische ethick alleen ging over 'specifieke problemen van de arts als arts'. Er waren echter veel problemen die buiten de sfeer van het beroep vielen. Zo rekende Van Till de vraag of een levensbehoudende behandeling van een patiënt gestaakt mocht worden tot een probleem buiten de beroepssfeer van de arts. Dit betekende ook dat de oplossing van het probleem, in ieder geval deels, van buiten de medische professie zou moeten komen. Van Till claimde hiermee onmiddellijk de nodige ruimte en legitimatie voor zeggenschap hierover vanuit het recht (Van Till-d'Aulnis de Bourouill 1970: 10). Bij haar poging cen zowel 'juridisch als ethisch verantwoorde' omschrijving van euthanasie te geven, hechrte ze bijzonder aan 'het belang van de patiënt'. Er circulcerden in die tijd vele betekenissen van het begrip euthanasie (Marlet 1969). Van Till omschreef 'het toepassen van euthanasie' als: een op medische indicatic berusunde levensverkortende opzettelijke medische gedraging, dienend om voor een ongeneeslijk ziekc en ondraaglijk lijdende patiënt een goedc dood mogelijk te maken, of om het lijden te verkorten; deze gedraging wordt gedaan in het belang van de patiënt, althans niet tegen diens belang, en zeker niet alleen in het bclang van anderen; voor geoorloofde euthanasic is vereist dat de pariënt weet dat euthanasie wordt (zal worden) toegepast en dat hij het daarmee eens is. Zoals het 'respect voor menselijk leven' een geschreven (medisch-ethische) richtlijn was, beschouwde Van Till het 'belang van de patiënt' als een ongeschreven richtlijn. ${ }^{15}$ Hiermee gooide ze een nieuwe eigendomsclaim in de strijd. Om het belang van de patiënt te onderstrepen pleitte ze voor een nieuw persoonlijkheidsrecht: het recht op onverstoord sterven. 'Het recht op onverstoord sterven is a.h.w. het patiëntenaspect van de euthanasie' (Van Till-d'Aulnis de Bourouill 1970: 26). Met dit nieuwe 'recht' reikte Van Till de 'verontruste medici en ethici' dus een oplossing aan om om te gaan met de nieuwe vragen.

Overigens verzette Van Till zich tegen het aanduiden van de 'nieuwe situatie' in termen van 'medische terreur' (in de trant Van den Bergs 'medische macht en medische ethiek). Ze vond die benaming niet terecht, omdat daarmee de 'schuld' op de schouders van artsen werd geschoven. Ze wilde de arts niet de schuld geven, maar hem "juist de juridische steun geven bij beantwoording van de vraag of hij, juridisch gezien, onder bepaalde omstandigheden en voorwaarden de beslissing mag nemen om bepaalde technieken niet toe te passen en zelfs de levensbehoudende behandeling van een patiënt te staken, zonder in conflict te komen met de wet of de algemene medische ethiek.' Hulp bieden bij moeilijke beslissingen door artsen was precies de rol die zij zag weggelegd voor het 
recht en de ethiek (Van Till-d'Aulnis de Bourouill 1970: 56). Het recht zou daarbij richtlijnen moeten aangeven op basis van de ethiek (p. II). Dit kwam met andere woorden neer op een gedeeld eigendom en een duidelijk afgebakende jurisdictie. Niet alleen het streven van Van Till om juridische steun aan artsen te geven in plaats van ze in het beklaagdenbankje te zetten moet artsen gerustgesteld hebben. Ook het feit dat Van Till wilde voorkomen dat nietmedici op eigen hourje en wijze euthanasie gingen toepassen (indien de behandelend arts daartoe niet bereid zou zijn) moet, in het licht van zeggenschap door en verantwoordelijkheid van de medische professie, voor artsen een geruststelling zijn geweest (Van Till-d'Aulnis de Bourouill 1970: 107).

\section{Actieve en passieve euthanasie}

Niet alleen in professionele kring kreeg medische ethiek in het kader van levensbeëindiging aandacht. Ook op overheidsniveau speelde de crisis in de medische ethiek, mede naar aanleiding van het beeld waar Van den Berg het land mee had opgeschrikt. Bij de behandeling van de begroting van het Departement van Sociale Zaken en Volksgezondheid in 1970, kwam her onderwerp van de toenemende onzekerheid inzake medisch-ethische vraagstukken in de Tweede Kamer aan de orde (Gezondheidsraad 1972). Er werd een verzoek aan de staatssecretaris gedaan om een commissie in te stellen die het vraagstuk van 'de medische macht en de medische ethiek' zou moeten bestuderen. Daarbij had men een gevaricerde medisch-ethische thematiek voor ogen rond: conceptie, geboorte, leven en sterven. De gedachten gingen uit naar een commissie met naast medische hoogleraren en artsen ook ethici en eventueel hoogleraren sociale psychologie. Dit verzoek kwam bij de Gezondheidsraad terecht en daar werd een commissie Medische Ethiek bestaande uit 18 leden samengesteld, waaronder vijf juristen en één moraaltheoloog. De voorzitrer van de commissie, de hoogleraar De Vreeze, was zelf jurist. De commissie besloot eerst aandacht te schenken aan de vragen rond euthanasie, omdat die kwestie het meest urgent leek en er 'nog slechts weinig officiële uitspraken' en 'weinig groepsmeningen' waren gepubliceerd (Gezondheidsraad 1972: 6). ${ }^{16}$ Vanwege de nauwe samenhang van ethiek en recht, aldus de commissie, besprak zij ook de rechtsregels. $\mathrm{Na}$ ruim twee en een half jaar kwam de Commissie Medische Ethiek met een interim-advies inzake euthanasie uit. De commissie achtte het niet mogelijk om algemeen aanvaardbare ethische regels op te stellen. De vigerende pluriformiteit in de medische ethiek werd zelf als oorzaak van de onzekerheid rond medisch handelen beschouwd. De medische professie velde namelijk niet meer in haar eentje een oordeel over medisch-ethische problemen, maar werd omringd door ethici en juristen. Bovendien was de commissie ervan overtuigd dat ethische normen 'sterk sociaal-cultureel bepaald' waren, 'in tegenstelling tor de 
geschreven rechtsnormen'. ${ }^{17}$ Ze was van mening dat er geen 'innerlijk gesloten medische ethiek' bestond, maar dat medische ethiek een verbijzondering of toepassing was van de algemene ethiek. Dat betekende dat richtlijnen voor het handelen van artsen afgeleid zouden moeten worden van de algemene ethiek. Zo zouden ook de rechten van de patiënt afgeleid moeten worden van de rechten van de mens (Gezondheidsraad 1972: 15).

De commissie gaf een lijst van definities ten aanzien van euthanasie en maakte daarbij onderscheid tussen: euthanasie, vrijwillige euthanasie, onvrijwillige euthanasie, passieve euthanasie en actieve euthanasie. ${ }^{18}$ De commissie introduceerde een nieuwe term die paste binnen een juridisch vocabulaire; de wilsverklaring. Ze onderscheidde namelijk twee probleemsituaties ten aanzien van euthanasie. De eerste was die waarin een pariënt een geldige wilsverklaring kon afleggen en de tweede was die waarin dat niet (meer) kon. In de eerste situatie gold volgens de commissie dat de wilsverklaring richtsnoer was voor doen en laten van de arts. De patiënt zou 'zijn eigen morele opvattingen en zijn rechten' hebben, 'waarmee de arts rekening heeft te houden'. In het tweede geval zou de arts 'naar zijn beste weten en vermogen, volgens zijn kennen en kunnen, altijd primair in het belang van zijn patiënt, en met inachtneming van diens geldige wil en rechten', moeten besluiten tot handelen of niet handelen. De commissie concludeerde vervolgens dat actieve euthanasie strafbaar moest blijven. Ze gaf als het ware twee oplossingen. Actieve euthanasie bleef via wetgeving geregeld, maar passieve euthanasie daarentegen zou niet door nieuwe wetten hoeven te worden geregeld. Dat zou via een 'recht van de patiënt' kunnen worden opgelost. Aan de patiënt werd namelijk het recht toegekend om een medische behandeling te weigeren (door middel van een geldige wilsverklaring) (Gezondheidsraad 1973: 36).

Het hoofdbestuur van de KNMG sloot zich aan bij het eerste interim-advies over euthanasie van de Gezondheidsraad. Sterker nog, zc accepteerde dit rapport als een 'voorlopige stellingname' (Leuftink 1973). Daarmee werden ook de verschillende onderscheidingen in vrijwillige, onvrijwillige, actieve en passieve euthanasie onderschreven. Bij de definitie van eurhanasie werd in het rapport de kanttekening gemaakt dat het niet alleen om een ongeneeslijke patiënt zou moeten gaan. Het hoofdbestuur nuanceerde dit en was van mening dat 'euthanasie bij een ongeneeslijke patiënt slechts mag worden overwogen, indien het stervensproces is ingetreden'. Deze voorwaarde gaf artsen uiteraard meer zeggenschap en politieke verantwoordelijkheid in deze.

Juristen en ethici gaven bij het onderscheid tussen actieve en passieve euthanasie aan hoe de rol van de patiënt en de arts er volgens hen uit zou moeten zien. Toch was dit onderscheid tussen actieve en passieve euthanasie in juridische literatuur niet gangbaar. Binnen het recht gold het standaardargument dat het geen verschil maakte of de dood veroorzaakt werd door te handelen of door een 
handeling na te laten, waartoe men overeenkomstig de wet toe verplicht was. Maar de jurist Rang achtte dit onderscheid wel zinvol, omdat zijns inziens 'de patiënt het volle recht heeft een behandeling te weigeren' (Rang 1972b: 270). ${ }^{19}$ Niettemin had hij een dubbele houding ten opzichte van de rol van de patiënt. Zo achtte hij het juridisch namelijk niet te veroordelen als een 'arts bijv. op goede gronden t.a.v. een al dan niet bewusteloze patiënt die zich in het terminale stadium bevindt' besluit 'dat verdere behandeling geen zin heeft of onmogelijk is'. Een arts zou in een dergelijk geval de behandeling mogen staken, 'ook al verzet de patiënt zich daartegen'. Collega Van Till vond deze uitspraak aanvechtbaar. Ook zij onderschreef het onderscheid tussen actieve en passieve euthanasie, maar voor haar was belangrijker: 'Welke plichten had de arts in dit geval en heeft hij die wel of niet vervuld? Heeft hij daarbij rechten van anderen geschonden?' (Van Till-d'Aulnis de Bourouill 1972: 178). Passieve euthanasie was volgens haar dan ook alleen mogelijk op initiatief van de patiënt en in geval van een 'geldige wens' van de patiënt. Van Till hanteerde een juridisch vocabulaire (plichten, rechten schenden, geldige wens) waardoor de arts-patiëntrelatie als een contractrelatie werd geschetst. Ze nam daarmee impliciet de patiënt in bescherming.

Op een speciaal symposium over euthanasie stelde de ethicus Sporken dat 'actieve euthanasie buiten weten en willen van de patiënt niet kon worden beschouwd als een ethisch aanvaardbare vorm van stervenshulp' (Sporken 1973: 56). Zijns inziens was de beslissing tot actieve euthanasie een 'zodanig persoonlijke beslissing' dat niemand die namens de patiënt kon nemen, ook ouders niet namens hun kind. Om heel andere redenen dan Rang en Van Till maakte dus ook Sporken ruimte vrij voor de patiënt. Hij nam de patiënt echter niet zozeer in bescherming, zoals Van Till duidelijk wel deed. Sporken hanteerde meer een wijsgerig-antropologisch perspectief: niemand kon gewoonweg de plaats van de patiënt innemen als het om een dergelijke ingrijpende beslissing gaat. Eerder had Sporken in zijn handboek over medische ethiek laten weten dat het hem onmogelijk leek om een wezenlijk onderscheid te maken tussen passieve en actieve euthanasie. Ethisch gezien zou er geen wezenlijk, maar slechts een gradueel verschil bestaan tussen een daad waardoor men iemand doodt en het opzettelijk nalaten van een daad, waardoor iemand sterft (Sporken 1969b: 22I).

In de literatuur werd dus volop gediscussieerd over de stand van zaken rond actieve en passieve euthanasie en de rol van de patiënt hierin. Ondertussen werd op 2I februari 1973 een vonnis geveld door de rechtbank in Leeuwarden. ${ }^{20}$ Een vrouwelijk arts in Friesland had bijna anderhalf jaar daarvoor bij haar ernstig zieke en zwaar lijdende oude moeder, op haar verzoek, euthanasie toegepast. In de terminologie van destijds was dit een geval van actieve vrijwillige euthanasie. In tegenstelling tot de Commissie Medische Ethiek van de Gezondheidsraad achtte de rechtbank actieve euthanasie onder bepaalde omstandigheden wel 
toegestaan. Deze uitspraak was mede gebaseerd op een verklaring van de als getuige gehoorde inspecteur van de volksgezondheid in Friesland. ${ }^{21}$ Volgens deze getuige zou het in brede medische kring aanvaard zijn om in bepaalde omstandigheden opgaande doses medicatie toe te dienen, met als neveneffect levensverkorting. ${ }^{22}$ De door de getuige-deskundige opgestelde lijst met opgestelde criteria gold zowel voor lichamelijk als geestelijk lijden, met als uitgangspunt: verzachting van het lijden. Op dat moment waren dus justitiële normen aangegeven waarbij euthanasie door een behandelend arts toelaatbaar moest worden geacht ${ }^{23}$ Deze normen reikten veel verder dan de stellingnames in het rapport van de Gezondheidsraad of van het Hoofdbestuur van de KNMG. Door de grote aandacht in de media voor dit proces kwam euthanasie ook voor de Nederlandse bevolking tot leven. Er vloeiden initiatieven uit voort die in datzelfde jaar hebben geleid tot de oprichting van de Nederlandse Vereniging van Vrijwillige Euthanasie (NVVE) en de Stichting Vrijwillige Euthanasie (SVE).

Er was geen eenduidig gebruik noch een eenduidige betekenis van de verschillende begrippen. Aan de veelheid aan begrippen rond euthanasie leek men maar moeilijk een einde te kunnen maken. De kluwen van definities en de gooi naar 'oplossingen' geven aan dat er geen eenduidige zeggenschap over de problematiek hestond. In hun beschouwingen hierover waren juristen directiever dan ethici, met name op het punt van de wil van de patiënt. Ethici namen een meer beschouwende dan claimende positie in, maar over het algemeen was er geen strak onderscheid te onderkennen tussen de juridische en ethische bijdragen. Tót er in 1977 een speciale bundel over euthanasie werd uitgebracht in de serie De Nederlandse Bibliotheek der Geneeskunde (Muntendam 1977). De ethische bijdragen en de juridische bijdrage daarin verschilden op een aantal cruciale punten. Zo wilde de moraaltheoloog Beemer euthanasie uit de artspatiëntrelatie halen. Euthanasie zou veel minder als een zaak van artsen moeten worden beschouwd. Volgens hem zou 'de beroepsgroep der artsen (...) de maatschappij een slechte dienst bewijzen, als ze deze discussie zou opeisen en in haar eigen vocabulaire zou opsluiten. Reeds het spreken over "indicaties" tot passieve of actieve euthanasie is een symptoom van dit gevaar' (Beemer 1977: 33). Hij stelde zelfs het min of meer gangbare onderscheid tussen vrijwillige en niet-vrijwillige euthanasie ter discussie door het 'eigen oordeel' te relativeren. Daarmee trok hij in twijfel dat: 'euthanasie buiten de wil van de patiënt om zo principieel zou verschillen van euthanasie volgens zijn wil'. Met andere woorden: was het wel mogelijk om de wil van de patiënt te kennen bij het vraagstuk van de levensbeëindiging? Euthanasie tegen de wil van de patiënt was volgens hem onaanvaardbaar. Maar euthanasie volgens de wil van de patiënt was niet per definitie aanvaardbaar.

De gezondheidsjurist Leenen beweerde van het laatste juist het tegenovergestelde. Niemand dan de persoon zelf kon volgens hem oordelen over de zin 
van het leven. Leenen definieerde euthanasie als: 'Een opzettelijk levensverkortend handelen (inclusief nalaten) door een ander dan de betrokkene op diens verzoek' (Leenen 1977: 80). Hij ageerde tegen de vele definities van euthanasie waarin elementen waren opgenomen als dat het zou moeten gaan om: stervensfase, ongeneeslijke ziekte, ondraaglijk lijden etc. Leenen noemde dit 'oneigenlijke begripsomschrijvingen', omdat het in een definitie alleen om objectieve kenmerken zou moeten gaan en niet om ethische oordelen. Daardoor zou namelijk 'verwarring in denken en vervalsing van discussie' ontstaan. Volgens Leenen moest er een onderscheid gemaakt worden tussen euthanasie en schijngestalten van euthanasie, onder de laatste rekende hij onder meer het staken van een zinloze medische behandeling, 'euthanasie' bij pasgeborenen, indirecte 'euthanasie' en het weigeren van een medische behandeling (p. 10o). Overigens liepen bij de auteurs die een bijdrage hebben geleverd aan de bundel van Muntendam de meningen over de 'juiste' terminologie en onderscheidingen zeer uiteen. Leenen ging mee in de teneur dat euthanasie als nieuw probleem zou zijn veroorzaakt door ontwikkelingen in de medische wetenschap en techniek. Hij legde de verantwoordelijkheid voor een oplossing daarmee bij de geneeskunde. Zij zou een oplossing moeten vinden, bijvoorbeeld door het zoeken naar een goede vorm van stervenshulp. Daarnaast claimde Leenen ook dat de vraag om euthanasie sterk gestimuleerd was door de ontwikkeling van de mensenrechten, 'die in het kader van de gezondheidszorg steeds meer reliëf hebben gekregen' (Leenen 1977: 74). Door her probleem dus aan de ene kant als medisch-wetenschappelijk en aan de andere kant als een mensenrechtenprobleem te definiëren, schiep Leenen de kaders voor een medisch-juridisch aanpak ervan. In tegenstelling tot de ethicus Beemer, die euthanasie juist uit de arts-patiëntrelatie wilde halen en daarmee dus eurhanasie van de medische context los wilde weken.

Ten aanzien van het onderscheid tussen actieve en passieve euthanasie stelde Leenen dat er juridisch en ook moreel gezien geen onderscheid was tussen handelen en nalaten van handelen (p. 97). Hij noemde dit een niet valide onderscheid. Aangezien passieve euthanasie namelijk 'vrijwel algemeen aanvaard' was, zou actieve euthanasie ook aanvaard moeten worden. Zijns inziens ging het in wezen om het onderscheid tussen vrijwillige en niet-vrijwillige euthanasie en was het onderscheid actief-passief een 'versluiering van de werkelijkheid'. Want ook passieve euthanasie zou alleen op verzoek van de patiënt toegepast mogen worden (Leenen 1977: 98). Leenen besloot met de woorden: 'De hier verdedigde opvatting, zal gezien de gegroeide mening over passieve euthanasie in sommige kringen, wellicht weerstand oproepen, doch vanuit de benadering van het zelfbeschikkingsrecht van de mens en vanuit de juridische leer met betrekking tot handelen en nalaten kan niet anders worden gesteld, dat er geen onderscheid tussen actieve en passieve euthanasie bestaat' (p. 99). 
De ethicus Heering was in zijn bijdrage aan de bundel van Muntendam minder radicaal dan zijn collega Beemer. Hij kwam niet tor een duidelijk standpunt voor of tegen euthanasie, maar beperkte zich voorzichtig tot een 'nee, tenzij' (Heering 1977: 29). Hij relativeerde echter wel de wil van de patiënt, want 'in de vraag naar euthanasie kan de ònbereidheid om er zelf een einde aan te maken verstopt liggen, alsook de neiging om de laarste verantwoordelijkheid voor eigen leven op een ander af te schuiven' (p. 24). Bovendien 'worde nimmer vergeten wat ik al eerder noemde: dat het verlangen naar de dood vrijwel altijd samenhangt met het ontbreken van een echte naaste, van een leefbare wereld, en van een geloofshouvast. Dat is het waarheidselement in de stelling dat euthanasie niets anders mag betekenen dan levens- en stervensbegeleiding' (p. 25). Heering zag de vraag om euthanasie dus primair als een sociaal probleem (geloof, leefbare wereld) van de samenleving. Euthanasie was in eerste instantie niet de werkelijke wil van de patiënt, maar vloeide voort uit de inrichring van de samenleving. Hij beschouwde euthanasie, vanuit een christelijk-antropologisch perspectief, dan ook als een vorm van 'hulp bij zelfmoord'. Kortom, in de ethische bijdragen van de bundel werd euthanasie primair losgeweekt uit een medische context en in de juridische bijdrage werd juist de medisch-juridische context voor de vragen van euthanasie benadrukt.

Het alomvattende idee van een 'crisis' binnen de medische ethiek heeft als een olievlek gewerkt en de verspreiding van zeggenschap over medische ethiek mogelijk gemaakt. Door de medische professie werd medische ethiek niet meer slechts als een kwestie van beroepscodes beschouwd, maar als een meer pluriforme materie. De KNMG hanteerde begin jaren zeventig expliciet een multidisciplinaire benadering van ethiek binnen de context van levensbeëindiging. Dit was voor ethici en juristen aanleiding om een aantal zaken voor het voetlicht te brengen. Ethici benadrukten vooral de sociale aspecten van het medisch handelen en bijvoorbeeld Sporken pleitte voor euthanasie in her kader van de stervenshulp. Bovendien benadrukten ethici dat medische ethiek een kwestie was die de hele maatschappij aanging. Daarmee claimden ze dus niet direct een bepaalde expertise of rol voor zichzelf. Juristen schepten een medisch-juridisch kader om de problemen rond euthanasie een oplossing te kunnen bieden. In de medisch-juridische setting werd een duidelijke plaats toebedeeld aan zowel de arts als de patiënt. De arts werd exclusief de rol van uitvoerder van euthanasie toegekend, omdat hij de enige zou zijn die de alternatieve opties kon bekijken in een dergelijke situatie. Daarentegen stelden ethici juist het feit dat een arts het zou moeten doen ter discussie. $\mathrm{Zij}$ reduceerden het toepassen van euthanasie tot een technische taak. De aandacht voor stervensbegeleiding had meer prioriteit. Ten aanzien van de patiënt stelden ethici ter discussie of de wil van de patiënt wel geldig kon zijn en of een vraag om euthanasie niet als een roep om aandacht geïnterpreteerd moest worden. Juristen benadrukten het verzoek van de patiënt 
als legitimatie voor het uitvoeren van euthanasie. Dan en slechts dan zou euthanasie te verantwoorden zijn, als antwoord op de steeds toenemende medische macht. Passieve euthanasie was niet meer dan het weigeren van een behandeling. Het was de plicht van een arts om dat recht te erkennen. Niet alle ethici gingen mee in dit juridisch vocabulaire. Degenen die een andersoortige positie innamen, hanteerden een meer wijsgerig-antropologisch perspectief op levensbeëindiging. Vanuit dat perspectief namen de vragen rond euthanasie eerder toe dan af.

\section{Wat geldt als 'normaal medisch handelen'?}

\section{Een 'objectieve' definitie en versmalling van de discussie'}

De vele onderscheidingen in het begrip euthanasie zorgden ervoor dat het probleem verkaveld raakte. Er was geen consensus over een definitie voor de kwestie. Er was geen sprake van één groor afgebakend probleem, maar van cun geclusterde groep aanverwante problemen. Daarnaast was er ook niet één dominante stroming in de discussie te onderkennen. Juristen waren over het algemeen beter vertegenwoordigd in het georganiseerde veld (overheidscommissies) en hadden zowel inhoudelijk als politiek meer aansluiting bij artsen. Er was een gedeelde verantwoordelijkheid onder artsen en juristen voor de problematiek mét een duidelijke taakverdeling. Van juristen werd opheldering verwacht en menigeen was ook bereid zijn of haar juridisch stemgeluid te laten horen. De uiteindelijke beslissing lag in handen van de arts. Ethici verspreidden los van elkaar hun beschouwingen en adviezen. Deze vaak filosofische beschouwingen bleken minder krachtig in her toe-eigenen van het issue dan de juridische suggesties die meer op beleid en regulering gericht waren. In de jaren tachtig werd deze trend voortgezet en kristalliseerde er een medisch-juridische definitie uit van euthanasie. Daaruit bleek tevens dat het collectieve probleem van de jaren zeventig, ('hoe kan de medische macht ingeperkt worden?') in de definitie van euthanasie werd verdisconteerd. Euthanasie werd gedefinieerd als levensbeëindiging op verzoek van de patiënt. Het probleem van de jaren tachtig was de vraag hoe deze vorm van euthanasie gelegitimeerd kon worden.

Leenen heeft zich al in een vroeg stadium van de discussie, zoals ook de vorige paragraaf heeft laten zien, beijverd voor een 'objectieve' definitie van euthanasie. In zijn handboek over Rechten van mensen in de gezondheidszorg (1978) stelde hij voor om onder euthanasie te verstaan: een opzettelijk levensverkortend handelen (inclusief nalaten) door een ander dan de betrokkene op diens ver$z o e k$. Daarmee nam hij afstand van de vele andere definities die er circuleerden, waarin elementen als de stervensfase, het belang van de pariënt of ongeneeslijke 
ziekte waren opgenomen. 'Over deze toevoegingen verschillen overigens de meningen. Dit wordt veroorzaakt door het feit, dat deze toevoegingen oordelen over, de al dan niet geoorloofdheid van euthanasie, in de definitie (beogen te) brengen. Dit is geen juiste wijze van denken. Bij de definiëring van een begrip gaat het om de objectieve kenmerken die het wezen van het te definiëren begrip bepalen' (Leenen 1978: 213). In vele artikelen heeft Leenen deze boodschap herhaald. In het genoemde boek maakte Leenen onderscheid tussen euthanasie en schijngestalten van euthanasie. Onder de laatste rekende hij een categorie van handelingen rond het einde van het leven, die de discussie over euthanasie zijns inziens 'vertroebelden' ${ }^{24}$ Het maken van een dergelijk onderscheid impliceerde dus een 'ware' vorm van euthanasie. En dat is ook precies wat Leenen hier claimde. Met dit onderscheid richtre Leenen sterk de aandacht op euthanasie sec, dus zoals wij nu euthanasie gedefinieerd hebben (op verzoek, door een arts). Dat was volgens hem namelijk het werkelijke probleem waar het om ging. Dir consequent aandacht vragen voor de letterlijke definitie van het probleem had vergaande implicaties. Een definitie betekent namelijk zowel een claim als een ingreep in het debat. De moeite die Leenen zich getroostte om een zijns inziens juiste definitie van euthanasie te bewerkstellingen staat in schril contrast met het uitgangspunt van de ethicus Kuitert. Deze stelde dat een (goede) definitie van euthanasie louter op een afspraak berustte (Kuitert 198r: 29). In zijn eerste boek over euthanasie, Een gewenste dood nam Kuitert op een enkel woord na de definitie van Leenen over. Hij claimde dus niet, zoals Leenen, een bepaald aspect van de discussie in zijn verhandeling over de definitie van euthanasie.

Thans wordt voor de definitie van euthanasie vaak verwezen naar het rapport van de Staatscommissie uit 1985 . Deze lijkt op een aantal punten een bezegelende werking te hebben gehad. Eind jaren zeventig was het vraagstuk van euthanasie op de politieke agenda gekomen. Er was een motie bij de regering ingediend, met als voorstel om een staatscommissie in te stellen die advies uit zou gaan brengen over het toekomstige overheidsbeleid inzake euthanasie en hulp bij zelfdoding. In de praktijk bestond namelijk ondertussen een grote mate van (rechts) onzekerheid onder artsen en patiënten over de grenzen van de strafbaarheid van euthanasie. De Staatscommissie had opdracht gekregen advies uir te brengen over het toekomstige overheidsbeleid inzake euthanasie, met dien verstande dat dit advies betrekking moest hebben op wetgeving. $\mathrm{Zij}$ moest een knoop gaan doorhakken in de controverse rond het probleem van de rechtsonzekerheid van euthanasie: middels de weg van de wetgeving of via de jurisprudentie. Dat verklaart wellicht waarom juristen ten opzichte van ethici in de commissie sterker vertegenwoordigd waren. In 1982 werd de Staatscommissie ingesteld en zij kwam drie jaar later met haar rapport over euthanasie uit. De commissie bestond uit zowel medische, juridische als ethische expertise. Ze stelde voor om onder euthanasie 'het opzettelijk levensbeëindigend handelen 
door een ander dan de betrokkene op diens verzoek' te verstaan. Dit kwam overeen met het voorstel van Leenen en de inzet van het hoofdbestuur van de KNMG (KNMG 1984). Dit gold ook voor 'vrijwilligheid' als kernpunt bij euthanasie. Volgens Leenen had de Staatscommissie, om een legitimatie van haar standpunt te krijgen, de KNMG destijds ook nadrukkelijk om advies gevraagd. ${ }^{25}$ Ten tweede stemde de Staatscommissie in met de door de Gezondheidsraad onderscheiden handelingen die niet onder de noemer euthanasie zouden moeten vallen: het staken van een behandeling, stervenshulp die primair gericht is op pijnbestrijding, het staken van een behandeling op verzoek van de patiënt. Deze handelingen werden als 'normaal medisch handelen' bestempeld, en waren dus niet van belang voor het strafrecht. Door aan te geven dat het in de genoemde gevallen om normaal medisch handelen ging legde de Staatscommissie het probleem heel duidelijk bij de medische professie. Zij ging namelijk over medisch handelen.

Op het rapport van de Staatscommissie was vanuit ethische en juridische hoek commentaar gekomen. Daarin kwamen verschillende bewegingen in her toe-eigenen van de problematiek of het claimen van een bepaalde expertise naar voren. Vanuit de ethiek heeft ondermeer Dupuis op het rapport gereageerd. \%e stelde de deskundigheid van de commissie ter discussie. Voor halar stond een discussic over de spanning tussen 'het recht op leven' en 'de plicht tor leven' bij de euthanasieproblematiek centraal. Het ging volgens haar om de 'typisch ethische' vraag of een recht op leven ook een plicht tot leven impliceert. Deze ethische vraag was volgens haar niet aan bod gekomen. 'Het is betreurenswaardig dat de staatscommissie deze discussie niet heeft willen of kunnen voeren. (...). Het ware goed geweest, als de staatscommissie dit punt behandeld had. Dat mag immers verwacht worden van een raad van deskundigen. Misschien wreekt zich hier het gebrek aan know-how in de commissie op het gebied van de ethiek: de commissie beschikte immers maar over één ethicus' (Terborgh-Dupuis 1985). Haar commentaar was inhoudelijk en tegelijkertijd ook een demonstratie van ethische expertise. Daarmee eigende ze zich het issue op een bepaalde manier toe.

Roscam Abbing, hoogleraar gezondheidsrecht, was milder in haar commentaar. Zij zag in het rapport een bevestiging van de idee dat er helderheid moest komen voor arts en patiënt. Roscam Abbing prees de commissie voor haar 'open oog voor de problematiek' en her uitgangspunt dat 'duidelijkheid en rechtszekerheid voor zowel de arts als de patiënt' voorop stond. Wat betreft de kwestie rond de definiëring voegde ze daaraan toe: 'Ontegenzeggelijk heeft de Commissie met het huidige advies de nodige duidelijkheid weten te scheppen, zeker waar zij een einde maakt aan oneigenlijke hantering van het begrip euthanasie in de zin van passieve en actieve en directe en indirecte euthanasie' (Roscam Abbing 1985a). Een tweede jurist, Gevers, zag in het rapport van de 
Staatscommissie een goede aanleiding om het stadium van de 'passieve euthanasie' te verlaten. 'Onder "euthanasie" verstaat de Staatscommissie: her opzertelijk levensbeëindigend handelen door een ander dan de betrokkene op diens verzoek. Hiermee valt euthanasie in wezen samen met het delict omschreven in het huidige art. 293 Wetboek van Strafrecht. In tot nu toe gangbare definities was naast "handelen" ook veelal het element "nalaten" opgenomen, dit overeenkomstig de juridische overweging dat nalaten te handelen waar een plicht tot handelen aanwezig is met handelen gelijk staat. Terecht stelt de Staatscommissie, dat van een dergelijke plicht geen sprake meer is, indien de patiënt behandeling weigert en aldus uitdrukkelijk om nalaten verzoekt. (...) Het is te hopen, dat het verwarrende begrip "passieve euthanasie" hiermee uit de discussie zal verdwijnen.' Kennelijk waren de reacties op het rapport van de Staatscommissie van juridische zijde méér specifiek gericht op het definitievraagstuk dan de reacties van ethische zijde.

Hoewel inhoudelijk op een andere lijn dan Dupuis, demonstreerde collegaethicus Klijn in dezelfde periode ook een ethisch perspectief. In de bundel Euthanasie. Recht, ethiek en medische praktijk ging hij in op het thema doen en nalaten binnen de discussie over actieve en passieve euthanasie (De Graaf \& Klijn et al. 1985). ${ }^{.6} \mathrm{Om}$ de plaats van ethiek in deze discussie aan te duiden begon hij zijn hoofdstuk met: 'Wie meent dat in onderscheid tot recht en medicijnen de ethiek en het ethische tot de zachte sector van het leven behoren, vergist zich' (Klijn 1985). Hij maakte een onderscheid tussen ethische analyse (objectief) en ethische waardering (subjectief) en gebruikte dat onderscheid om de definitie van euthanasie te bekritiseren. Zo gaf hij Leenen een koekje van eigen deeg door hem te verwijten dat zijn definitie van euthanasie niet neutraal was. Leenen had zich, zoals we eerder in deze paragraaf hebben gezien, sterk beijverd voor een objectieve definitie voor euthanasie. Maar Klijn stelde: 'In de definitie van Leenen is "het uitdrukkelijk verzoek" een wezenlijk element en het heeft vanuit zijn opvatting over het zelfbeschikkingsrecht ipso facto een legitimerend karakter. Daardoor is zijn definitie ethisch geladen en niet neutraal' (Klijn 1985: 38). Zijn onderscheid tussen ethische analyse en ethische waardering vond echter geen bijval van vakgenoten. Halverwege de jaren tachtig leken juristen wat betreft de inzet in het euthanasiedebat dus meer op één lijn te zitten dan ethici. Ethici ontwikkelden wel een ethisch perspectief, of beter gezegd verschillende, maar dat bleek in het debat niet overtuigend genoeg.

\section{Levensbeëindiging 'op verzoek' en 'zonder verzoek'}

Er ontstond in de eerste helft van de jaren tachtig dus onder een groot aantal van de betrokkenen consensus over de definitie van eurhanasie. Met name juristen hebben veel werk verzet om tot een 'heldere en objectieve definitie' te komen, 
waarbij de uiteindelijke beslissing van euthanasie in handen van de arts lag. Euthanasie was dusdanig omschreven dat het een autonomiekwestie leek te zijn; het verzoek van de patiënt stond centraal. Dit beroep op de autonomie van de patiënt was echter geen uitkomst voor de categorie van de wilsonbekwamen. Voor zwaar-defecte pasgeborenen, comateuze patiënten, demente patiënten en psychiatrische patiënten ging het 'op verzoek' namelijk niet op. In het euthanasiedebat kenmerkten de tweede helft van de jaren tachtig en de jaren negentig zich dan ook door discussies over levensbekortend handelen bij wilsonbekwamen en de zogenoemde 'non-treatment decisions' (medisch zinloos handelen, beslissingen om niet te reanimeren). Artsen, ethici en juristen namen duidelijk verschillende standpunten in.

In het Handboek Gezondheidsethiek uit 1988 werd een overzicht gegeven van de 'belangrijkste morele problemen in de gezondheidszorg' en 'een handreiking geboden bij het aanpakken ervan' (De Beaufort \& Dupuis 1988). In het boek werd door diverse auteurs relatief veel aandacht besteed aan bovengenoemde materie. De arts Spreeuwenberg ging expliciet in op het thema 'Levensbeëindiging buiten aanwezigheid van een uitdrukkelijk verzoek van de betrokkene' (Spreeuwenberg 1988). Hij richtte zich op levensbeëindiging bij pasgeborenen. Hij verwees naar de jurist Leenen wat betreft het feit dat 'steeds meer waarde toegekend [wordt] aan de wil en de wens van de betrokkene' (p. 482). Hoewel euthanasie dus in de rechtspraak en door de Staatscommissie was gedefinieerd als een uitdrukkelijk verzoek, stelde Spreeuwenberg als 'medicus practicus' dat er voor hem 'onvoldoende redenen [waren] om de absolute eis te stellen dat bij de ontstentenis van een wilsuiting levensbeëindiging niet geoorloofd is' (p. 484). Hij relativeerde dus de expliciete eis van 'het verzoek' om tot levensbeëindigend handelen over te kunnen gaan. Levensbeëindigend handelen zou volgens Spreeuwenberg toegestaan zijn, indien 'vaststaat dat het kind geen toekomst als menselijk wezen heeft' (p. 486). Ook in andere bijdragen aan het handboek, met name door ethici, werd niet onverkort vastgehouden aan de eis van wilsbeschikking in soortgelijke omstandigheden (Salters 1988). Als alternatief werd voorgesteld om uit te gaan van de veronderstelde wil en het beste belang (Dupuis 1988a).

Van ethische zijde werd echter ook radicalere kritiek geleverd op de nadruk op zelfbeschikking. 'Steeds vaker wordt respect voor de autonomie van het individu beschouwd als basisnorm in de medische ethiek' (Ten Have \& Kimsma 1987: 8r). Dit zou tot gevolg kunnen hebben dat morele problemen niet meer beoordeeld konden worden vanuit een ethisch kader: ' (...) ook in de euthanasiediscussie wordt steeds vaker de indruk gewekt dat er toch eigenlijk geen probleem is als iemand vrijwillig en weloverwogen vraagt om euthanasie. Er kan zich een autonomiedogmatisme ontwikkelen waarbij het morele beraad direct wordt kortgesloten met een beroep op ieders keuzevrijheid' (p. 82). De auteurs waarschuwden dat zelfbeschikking geen ethisch handelen kon garanderen. 
Bovendien zou er door de focus op autonomie steeds meer in termen van rechten worden gesproken, waardoor het onderscheid tussen recht en ethiek zou vervagen. De ethicus Beemer, een verklaard tegenstander van de morele aanvaarding van euthanasie, was nog radicaler in de aanklacht tegen zelfbeschikking. 'De toespitsing van de euthanasie-omschrijving op het (uitdrukkelijk en aanhoudend) verzoek en op de vrijwilligheid betekent, historisch gesproken, een halvering en verminking van de ethische discussie' (Beemer 1986: 37). Hij had zijn bijdrage aan een bundel over euthanasie dan ook de weinig verhullende titel 'Tegen een halvering van de ethiek' gegeven. Beemer meende dat door de onevenredige aandacht voor zelfbeschikking het tweede beginsel waarop de discussie over euthanasie heeft gesteund, de mercy killing, verdrongen was. 'Deze halvering leidt tot intellectuele onzuiverheid en oneerlijkheid... Bovendien komt de verzwegen andere helft, zij het dan onder andere termen dan "euthanasie", tóch boven water: in de medische praktijk, in de filosofische en medische vaktijdschriften, in de betreffende commissies staat dodelijk handelen jegens zwaar defecte pasgeborenen en jegens andere mensen die geen verzoek kunnen vormen of uiten volop ter discussie' (p. 37). Beemer was van mening dat het criterium 'op verzoek', 'opgesteld als scheidslijn tussen een moreel aanvaardbaar en moreel onaanvaardbaar doden, geen stand zal houden', omdat het 'haaks op de praktijk en op het denken van vele artsen' stond. Hij gebruikte dus de medische praktijk als argument om de versmalling van de euthanasiediscussie te bekritiseren.

De andere vormen van levensbeëindiging niet op verzoek, waar Beemer op doelde, kwamen inderdaad toch wel onder de aandacht. In het onderzoek van de Commissie-Remmelink was bijvoorbeeld bewust niet alleen gekeken naar levensbeëindigend handelen op verzoek. ${ }^{27}$ Deze Commissie ging er van uit dat niet alleen euthanasie zoals omschreven door de Staatscommissie van belang was, maar juist alle beslissingen die het leven kunnen bekorten. Deels was dit de opdracht die zij had meegekregen, deels vonden de onderzoekers het zelf van groot belang dat ook de context van euthanasie werd geschetst om een beeld te krijgen van de plek die euthanasie daarin innam. Als werkdefinitie voor euthanasie hanteerde de Commissie de definitie van de Staatscommissie (p. 46). Voor het onderzoek echter 'is gekozen voor de neutrale, beschrijvende term: medische beslissingen rond het levenseinde' (Euthanasie r99r: II). Met het onderzoek van de Commissie-Remmelink was dus een nieuw concept geïntroduceerd, namelijk medische beslissingen rond het levenseinde. Dit begrip had betrekking op: euthanasie, pijn- en symptoombestrijding en het staken of niet beginnen van een levensverlengende behandeling.

In zijn boek Mag er einde komen aan het bittere einde? ging de ethicus Kuitert in op de achtergronden van de definitie voor euthanasie uit de jaren tachtig (Kuitert 1993). Aanvankelijk wilde hij zijn boek Een gewenste doodvan ruim tien 
jaar geleden slechts moderniseren. Tijdens het schrijven merkte hij echter dat dit een onmogelijke taak was. Volgens Kuitert was de euthanasiediscussie in een soort isolement geraakt en hij wilde het probleem, net als de Commissie Remmelink, breder benaderen. 'Wat ik in deze nieuwe versie heb gedaan is het thema "levensbeëindiging en euthanasie" niet alleen in zijn context maar ook in al zijn vertakkingen aan de orde stellen en het vervolgens, geleerd door de ervaring van de sindsdien verstreken jaren, aan een evaluatie onderwerpen. Waarover gaat het in de discussie, waarom kun je haar niet beperken tot een discussie over euthanasie (...)?' (Kuitert 1993: 7). De praktijk om euthanasie als levensbeëindiging op verzoek te formuleren had volgens Kuitert zeker voordelen, maar 'afspraken over woordgebruik - hoe noodzakelijk en nuttig ook - lossen geen problemen op. Integendeel, de haalbaarheid die we ermee gewonnen hebben, vraagt zijn prijs: andere vormen van levensbeëindiging werden natuurlijk wel genoemd maar om de zaak niet te vertroebelen stelselmatig buiten de discussie gehouden' (p. 14). Kuitert wees een aantal oorzaken aan voor de versmalling van de discussie over of tot euthanasie. Onder andere: de definitie ('maar afspraken over woordgebruik - (...) - lossen geen problemen op') en juridisering ('In het verlengde van deze inperking van het probleem ligt een zekere juridisering van de discussic, ook een versmalling: artsen vragen bij voorkeur naar wat de wet toestaat en wat niet. Dat zijn hoogst belangrijke vragen, maar ze moeten zich niet op de voorste rij zetten. Dokters moeten allereerst vragen wat vanuit hun medische professie moreel aanvaardbaar of onaanvaardbaar is en hun medisch handelen niet, hoe begrijpelijk dat ook is vanuit het vervolgingsbeleid, laten sturen door de officier van justitie of door de rechter'). Kuitert stelde dat levensbeëindigende handelingen in een 'breder kader thuis horen dan ze veelal toebedeeld krijgen, in elk geval in een kader waaraan het, als medische handeling, zijn zin moet kunnen ontlenen' (p. I5). Hij pleitte, net als eerder zijn collega Sporken voor de begeleiding van stervenden als context (p. I8).

Ten aanzien van levensbeëindiging niet op verzoek zette Kuitert het argument van barmharrigheid in, dat door Beemer als tweede pijler in de discussie was betiteld. Misschien was her wel een angstig idee dat artsen levensbeëindigende handelingen niet op verzoek zouden verrichten, maar in sommige gevallen was het niet beëindigen van het leven volgens Kuitert nog veel schokkender (Kuitert 1993)..$^{28}$ Daarom luidde het adagium voor Kuitert: een goede arts bespaart zijn patiënt het bittere einde. In een recensie over Kuiterts boek schreef de jurist Leenen dat Kuitert met zijn boek een belangrijke bijdrage had geleverd aan de discussie over euthanasie. Maar tegelijkertijd betichtre hij Kuitert van 'juridische misstappen'. 'Zo zet hij bijvoorbeeld zonder meer de stap van de taak van de arts om de patiënt niet in de steek te laten en hem het bittere einde te besparen, naar de stelling dat euthanasie normaal medisch handelen op medische indicatie is' (Leenen 1994a). 
De KNMG besteedde in haar zogenaamde CAL-rapporten (Commissie Aanvaardbaarheid Levensbeëindigend handelen) uitgebreid aandacht aan het probleem van levensbeëindiging zonder verzoek. ${ }^{29} \mathrm{Zij}$ stelde dat hoewel politieke consensus over euthanasie al moeilijk was - er was op het politieke vlak nog steeds geen echte oplossing - het toch wenselijk was dat ook over de problemen van de wilsonbekwamen werd nagedacht. De medische praktijk mocht volgens de KNMG niet uit het oog verloren worden. 'Om dit oogmerk ten volle tot zijn recht te laten komen heeft de commissie er de voorkeur aan gegeven zich slechts zijdelings in de vraag te verdiepen of c.q. in hoeverre haar gedachtevorming ter zake in overeenstemming kan worden gebracht met de bestaande juridische rechtsregels op dit punt' (KNMG 1993: 2). De KNMG vond dus dat niet langer kon worden gewacht met meningsvorming rond dit heikele onderwerp. Het was een probleem dat in de praktijk speelde en of hier nu wel of geen juridische kader voor was, er zou over nagedacht moeten worden. Vandaar dat de rapporten ingingen op het algemene begrip 'levensbeëindigend handelen'. Dit werd gedefinieerd als: alle handelingen van artsen, die het overlijden van een wilsonbekwame patiënt beogen, ongeacht of deze het toedienen van euthanatica, pijnbestrijding, het niet aanvangen of staken van de behandeling dan wel enigerlei tussenvorm daarvan betreffen (KNMG 1993).

De jurist Leenen was heel duidelijk in zijn mening over levensbeëindiging zonder verzoek. Hij vond dit in geval van ondraaglijk lijdende patiënten, in tegenstelling tot de Commissie Remmelink, geen kwestie van het verlenen van stervenshulp en normaal medisch handelen. De Commissie Remmelink zag in dat geval in medisch-technisch opzicht geen verschil met euthanasie, Leenen wel. 'Er is een wezenlijk verschil tussen actieve levensbeëindiging op verzoek en zonder verzoek. Voorts wordt in brede kring euthanasie niet als normaal medisch handelen aangemerkt (...). Bij levensbeëindiging zonder verzoek kan al helemaal niet van normaal medisch handelen worden gesproken' (Leenen 1992: 47 (b)). Hij meende dat de Commissie Remmelink op deze manier levensbeëindiging zonder verzoek naar de artsen wilde afschuiven (Leenen 1992a: 7). Leenen was van mening dat juist door levensbeëindiging te beperken tot 'op verzoek' de euthanasiediscussie 'in Nederland op een verantwoorde manier gevoerd' kon worden (Leenen 1992a: 6). Hij was het dan ook absoluut niet eens met het voorstel van de regering om levensbeëindiging op verzoek en zonder verzoek in eenzelfde meldingsprocedure onder te brengen. 'Al met al meen ik dat ten aanzien van levensbeëindiging zonder verzoek een ongelukkige situatie aan het ontstaan is' (p. 7) (Leenen 1992a). Niettemin trad op r juni 1994 een Algemene Maatregel van Bestuur inzake de meldingsprocedure levensbeëindiging in werking.

Voortaan moest een arts zowel euthanasie, hulp bij zelfdoding als actieve levensbeëindiging zonder uitdrukkelijk verzoek melden bij de gemeentelijk 
lijkschouwer (de meldingsprocedure van 1990 had alleen betrekking op euthanasie en hulp bij zelfdoding). Dat hield in dat de volgende drie categorieën van medisch handelen tot normaal medisch handelen werden gerekend: $x$ ) het nietinstellen of staken van een behandeling op uitdrukkelijk verzoek van de patiënt; 2) het niet-instellen of staken van een behandeling waarin dit naar heersend medisch inzicht zinloos is; 3) het verrichten van een medische handeling of het toedienen van een middel tot pijnbestrijding met eventueel eerder overlijden als bijkomend gevolg (Van Dijk 1994). Met de nieuwe meldingsprocedure kwam er een einde aan een jarenlange discussie over de vraag of bepaalde levensbeëindigende handelingen door een arts bij de wet geregeld moesten worden (het Wetboek van Strafrecht blijft ongewijzigd). Levensbekortend handelen door een arts werd nu van overheidswege getoetst, waarbij de bereidheid van de medische professie om te melden centraal stond.

De beschrijving van aanvankelijk een inhoudelijke beperking van discussies rond euthanasie en vervolgens de uitbreiding ervan laat zien dat met name juristen zich hebben beijverd om tot een eenduidige definitie van euthanasie te komen. De definitie van de Staatscommissie, waarin juristen sterk vertegenwoordigd waren, werd uiteindelijk in de discussie overgenomen en steeds opnieuw bekrachtigd. Euthanasie is dan beperkt tot levensbeëindiging op verzoek. De consensus over her begrip euthanasie leek in de discussie helderheid te hebben verschaft, maar in de praktijk waren de problemen nog niet opgelost. De schijngestalten van euthanasie bleven terugkomen. Levensbeëindiging bij wilsonbekwamen was nog steeds een levensgroot probleem. Met name door ethici en artsen werd dit probleem aangekaart. Her autonomiediscours werd in verband gebracht met een juridisering en daarmee beperking van de discussie. De KNMG gaf door de instelling van de CAL te kennen naar een 'verbreding' van de euthanasiediscussie te streven. De Commissie Remmelink bekrachtigde het openbreken van de begrippen door de introductie van een nieuwe definitie, namelijk medische beslissingen rond het levenseinde. Dit betekende een uitbreiding van de discussie.

\section{Het recht van spreken bij vragen rond het levenseinde}

Aan de hand van het claimen van zeggenschap en het toebedelen en opeisen van diverse verantwoordelijkheden is onderzocht hoe de betrokken actoren (artsen, ethici en juristen) zich positioneren ten opzichte van elkaar. Door discussies over vragen rond het levenseinde op te vatten als het resultaat van een interactieproces was het mogelijk de dynamiek die hieraan ten grondslag ligt te onderzoeken. Welke rol en positie actoren hebben is niet vooraf bepaald. Deze krijgen pas vorm in de loop van het debat, in dit geval het debat over levensbeëindigend 
handelen in een medische context. Vanuit een historisch-sociologisch professionaliseringsperspectief heeft dit hoofdstuk laten zien dat opvattingen over de gevolgen van de ontwikkelingen in de medische technologie mogelijkheden boden voor de inmenging van nieuwe actoren op her gebied van de medische ethiek. Deze niche werd niet automatisch opgevuld; het stond namelijk niet bij voorbaat vast hoe en door wie. De (nieuwe) actoren moesten echter veel werk verzetten om een plek in het debat te verkrijgen en te behouden. In discussies over de definitie van het begrip euthanasie en de afbakening van het terrein van het debat vond deze positionering, door middel van het toewijzen en toebedelen van verantwoordelijkheden, plaats. Daar kan geen stabiele status aan worden toegeschreven. Actoren veranderden ook zelf tijdens dit proces. Door een nieuwe probleemdefinitie in het debat konden taken en verantwoordelijkheden weer gewijzigd worden, waardoor het spel van voren af aan begon.

In de loop van de jaren vijftig en zestig kwam de geneeskunde, in de context van reanimatie- en transplantatietechnieken, voor nieuwe vragen en onzekerheden te staan. Zo rees bijvoorbeeld de vraag of het opzettelijk achterwege laten van levensverlenging gelijk was aan het opzettelijk verkorten van het leven. De confrontatie met deze nieuwe vragen vond aanvankelijk uitsluitend binnen de medische professie plaats. Vervolgens kon de jurisdictie over medische ethiek veranderen, de medische professie was namelijk verdeeld over de manier waarop de nieuwe problemariek moest worden opgelost. Een deel van de medische professie meende dat er niets nieuws onder de zon was en beschouwde het als haar eigen verantwoordelijkheid om tot een oplossing te komen. Een ander deel van de medici zag hierin echter een rol voor moraal theologen, filosofen en juristen weggelegd en had dus een andere verantwoordelijkheid voor de gerezen problemen voor ogen. Al vrij snel werd gepoogd om de nieuwe problemen te onderscheiden van de kwesties in art. 293 van het Wetboek van Strafrecht, waarin een verbod staat op het beëindigen van het leven van een ander op diens uitdrukkelijk verzoek. Dit gebeurde vanuit twee kanten: door de medische professie en door de juridische professie. De directe associatie van de problematiek met art. 293 van het Wetboek van Strafrecht betekende een bijna vanzelfsprekende zeggenschap van juristen in deze. Maar er moest toch eerst veel werk verzet worden, voordat die zeggenschap ook tot tastbare resultaten leidde. Toen de KNMG als belangenbehartiger van de medische professie begin jaren zeventig officieel aankondigde dat haar een multidisciplinaire aanpak van de medische ethiek voor ogen stond, betekende dit een definitief afscheid van medische ethiek als een exclusieve zaak van de medische professie. De bijdragen van moraaltheologen en juristen aan het debat namen in aantal toe.

In de discussie ontstond vervolgens op grote lijnen consensus onder de betrokken actoren over de aard en de oorzaak van de problematiek. Medici en juristen definieerden de nieuwe problemen in termen van een toenemende 
medische macht. Er ontspon zich - onder artsen, juristen en ethici - een discours over (misbruik van) de medische macht, waarbij patiënten als slachtoffers van deze macht werden beschouwd. Dit gedeelde perspectief op de situatie betekende het begin van een zoektocht naar mogelijkheden om de medische macht in te perken. In dat proces kristalliseerden verschillende (definitie)claims en perspectieven uit. Zowel de arts als de patiënt kregen nieuwe rollen en taken toebedeeld. Hoewel er over de aard en oorzaak van de problemen consensus leek te zijn, was dat geenszins het geval over de vraag wat een geschikte oplossing zou zijn. Er werden grofweg drie aanzetten voor een 'oplossing' aangedragen, met elk impliciet een andere claim. Artsen en juristen bezonnen zich op nieuwe bevoegdheden voor de arts. Ethici benadrukten de sociale en levensbeschouwelijke aspecten van het medische handelen en vroegen aandacht voor stervensbegeleiding in de brede zin van het woord. En zowel juristen als ethici brachten de patiënt in het debat naar voren. Daaruit werd duidelijk dat zij een tweede sub-probleemdefinitie hanteerden: beperking van de medische macht via het versterken van de positie van de patiënt. In deze periode werd duidelijk dat de eigendom over de kwesties rond euthanasie verdeeld raakte en deels terecht kwam bij juristen en ethici. De zeggenschap werd in het debat niet meer vanzelfsprekend, zoals voorheen, bij de arts gelegd. Juristen benadrukten het verzoek van de patiënt als legitimatie voor het uitvoeren van euthanasie. Zij maakten hiermee een duidelijke claim. Sommige ethici betoogden dat de patiënt het laatste woord had, anderen stelden juist de wil van de patiënt ter discussie of vroegen zich af of een verzoek om euthanasie niet als een vraag om aandacht moest worden gezien. Door ethici werd dus niet als groep één patiëntenperspectief geclaimd.

Toen halverwege de jaren tachtig consensus werd bereikt over een formulering van het begrip euthanasie (als levensbeëindiging door een arts, op verzoek van de patiënt) leek daarmee een oplossing te zijn gevonden voor het probleem van de medische macht inzake het levenseinde. In die oplossing stond een duidelijke taakverdeling tussen arts en patiënt centraal. Mer name juristen hebben veel werk verzet bij het tot stand komen van deze definitie (en de uiteindelijke oplossing). Doordat er overeenstemming was over het begrip euthanasie, was er een onderscheid ontstaan tussen euthanasie en schijngestalten van euthanasie. Het staken van een behandeling (op verzoek) en pijn- en symptoombestrijding werden nu als normaal medisch handelen beschouwd en vielen daarmee 'vanzelfsprekend' onder de verantwoordelijkheid van de arts. Deze oplossing van het euthanasievraagstuk leek een bezegeling van een medisch-juridische coalitie inzake zeggenschap over euthanasie als medisch-ethisch probleem.

Daarin kwam echter verandering toen bleek dat het punt van de zelfbeschikking, dat eerst een 'oplossing' voor het probleem van de toenemende medische macht was, een knelpunt vormde in sommige situaties. Dat was aan- 
leiding voor nieuwe problemen en discussies. En nieuwe problemen betekenen nieuwe kansen op het terrein van de jurisdictie. Het debat over levensbeëindigend handelen zonder verzoek, dat door de definitie tijdelijk tussen haakjes was gezet, werd door ethici en artsen begin jaren negentig aangezwengeld. Voor juristen was het criterium van de zelfbeschikking zo bepalend dat zij worstelden met discussies over levensbeëindigend handelen bij wilsonbekwamen. Dit betekent dat ethici meer ruimte in het debat kregen om hun argumentatie, bijvoorbeeld het argument van barmhartigheid, in te zetten in het debat. Dezelfde ethische geluiden die in de jaren zeventig en tachtig niet of nauwelijks gehoor vonden, bleken nu wel een plek in de discussie op te kunnen opeisen.

De analyse van jurisdictie en van de eigendom over het probleem laat zien dat met betrekking tot zeggenschap over medische ethiek en euthanasie er sprake is van concurrentie en strijd. Door middel van definitievoorstellen, het aandragen van oplossingen en aanduidingen in tijdsordening zien we subtiele verschuivingen in de zeggenschap optreden. Er staat méér op het spel dan alleen het afbakenen van de betreffende problemen. Er vindt tegelijkertijd een competentiestrijd plaats en een toekenning van de verantwoordelijkheid voor het probleem. Daarnaast worden er oorzaken genoemd die verantwoordelijk zouden zijn voor het ontstaan van het probleem en worden daar oplossingen aan gekoppeld. Ethici concentreren zich meer op het beschouwende of filosofische kader van de discussie, terwijl juristen meer beleidsgericht denken. Juristen krijgen daardoor duidelijk meer zeggenschap in de definitiekwestie en dus meer grip op de vorm en inhoud van het debat in de jaren tachtig. Ethici houden het debat breed door hun interventies en werken ook mee aan de expansie van medische ethiek (Sporken, Dupuis). Doordat in de jaren negentig in het debat over euthanasie weer nieuwe zaken worden aangesneden naar aanleiding van de problematiek rond de wilsonbekwamen, krijgen ethici op hun beurt meer zeggenschap.

In dit hoofdstuk is impliciet uitgegaan van een bepaalde identiteit van de betrokken actoren. Moraaltheologen en filosofen zijn als vertegenwoordigers van de (zich ontwikkelende) discipline gezondheidsethiek aangemerkt en juristen als vertegenwoordigers van de discipline gezondheidsrecht. In het volgende hoofdstuk zal deze veronderstelling worden losgelaten om te onderzoeken hoe denkstijlen van de verschillende actoren zich hebben ontwikkeld en wat dit betekent voor de ontwikkeling van beide vakgebieden. Het volgende hoofdstuk behandelt het denken in termen van zelfbeschikking en autonomie als contragewicht bij een poging de medische macht in te perken. 


\section{DE ROL VAN DE PATIËNT BIJ LEVENSBEËINDIGEND HANDELEN:} EEN ONTWIKKELING IN DENKSTIJLEN EN PARADIGMATA

Het beeld van de autonome of mondige patiënt is niet meer weg te denken uit literatuur over de huidige gezondheidszorg.' Het algemeen geaccepteerde principe van 'informed consent' bijvoorbeeld - de geïnformeerde toestemming voor een behandeling - gaat uit van een autonoom handelende patiënt. De arts voorziet de patiënt van alle relevante informatie en de patiënt neemt op basis daarvan zelf een beslissing over een behandeling of onderzoek. Deze geïnformeerde toestemming door de patiënt is geregeld in de Wet op de geneeskundige behandelingsovereenkomst (Wgbo), waarin rechten van de patiënt centraal staan. De emancipatie en bescherming van de patiënt zijn belangrijke thema's in ethische en juridische literatuur (De Beaufort \& Dupuis 1988; Leenen I988b). De bescherming van de patiënt heeft zijn wortels in de toegenomen medische beslissingsmacht, als gevolg van ontwikkelingen in de medische technologie. Deze bescherming is in een specifiek vocabulaire tot uitdrukking gekomen: respect voor autonomie en het recht op zelfbeschikking.

Autonomie is één van de vier dominante ethische principes (naast weldoen, rechtvaardigheid en niet schaden), die voornamelijk op versterking van de positie van de patiënt gericht zijn. Zelfbeschikking of zelfbeschikkingsrecht vormt een centraal element in het gedachtegoed van het gezondheidsrecht. Het vorige hoofdstuk, waarin het probleem van de medisch-technische macht in de discussie over euthanasie aan de orde is gekomen, heeft laten zien dat de noties van autonomie en zelfbeschikking een belangrijke rol spelen in discussies over euthanasie. Ze hebben eerst als oplossing gefungeerd (in het kader van de definitie voor euthanasie; juristen hebben door deze versmalling van de discussie aan zeggenschap gewonnen) en vervolgens als probleem (discussie over levensbeëindigend handelen bij wilsonbekwamen; het breed houden van de discussie door ethici leverde nieuwe zeggenschap op in het debat). Het benadrukken van de autonomie en de zelfbeschikking van de patiënt is een gedeeld uitgangspunt van het gezondheidsrecht en de gezondheidsethiek.

In het kader van de probleemstelling van het onderzoek is de vraag is of we moeten uitgaan van twee verschillende denkstijlen voor beide vakgebieden (met verschillende moederdisciplines) of juist van een gedeelde of deels overlappende denkstijl. Dat wil zeggen, betekenen autonomie en zelfbeschikking hetzelfde binnen de twee disciplines of bedoelt men wat anders? 'Stijl' is hier in 
filosofische zin bedoeld, als een bepaalde grondhouding ten opzichte van de wereld. Een perspectief op de wereld, zonder dat dit primair een keuze is. Enerzijds lijkt er sprake van een stijlverschil. In hoofdstuk twee is bijvoorbeeld gewezen op een verschil in karakter tussen beide vakgebieden. 'Recht en ethiek verschillen namelijk nogal. Recht heeft een publiek karakter, vaak van dwingende aard (...). De ethiek daarentegen laat meer ruimte voor individuele keuzen (...). De ethiek is persoonlijker, daarmee wellicht flexibeler' (Schuyt 1997: 19). Een ander genoemd verschil betreft het verschil in waardenoriëntaties tussen recht en ethiek. In het gezondheidsrecht zouden rechtsbescherming, rechtszekerheid en een centrale positie van het individu van belang zijn. In de ethiek gaat het daarentegen om bredere waarden, namelijk 'het individu en diens relatie tot de (of diens) moraal'. Het begrip 'beneficence' zou daarbij centraal staan (Roscam Abbing \& Dillmann 1997: 222). Anderzijds wordt in de literatuur geclaimd dat autonomie het ethisch equivalent van het juridische begrip zelfbeschikking(srecht) zou zijn (Ten Have \& Ter Meulen et al. 1998: 120; Bekker \& Van der Burg 1994: 204). Dit zou betekenen dat er geen verschil maar juist een overeenkomst is in het gedachtegoed van beide vakgebieden. Binnen de ethiek is tevens discussie gevoerd over de vraag of de vereenzelviging van autonomie met zelfbeschikking als positief of als negatief zou moeten worden beoordeeld (Zwart 1993b). In dit hoofdstuk wordt de vraag onderzocht of er al dan niet sprake is van verschillen in denkstijlen en paradigmata voor ethiek en recht. ${ }^{2}$

$\mathrm{Na}$ een uiteenzetting van het theoretisch kader in de tweede paragraaf wordt in de daaropvolgende paragraaf eerst het 'oude' paradigma voor medische ethiek geschetst. Hierin kreeg de patiënt geen actieve, maar een passieve rol toebedeeld. Door een verschuiving in denkstijlen, anomalie en crisis is de dominante visie op de rol en functie van de pariënt geleidelijk veranderd. Deze verandering kwam tot uitdrukking in een crisis in de medische ethiek. Daaruit zijn aanvankelijk twee nieuwe denkstijlen opgekomen, die het belang van de patiënt expliciet op de agenda zetten. Eén van deze twee denkstijlen is uitgegroeid tor een nieuw, richtinggevend, denkkader. Vervolgens staat in de vierde paragraaf centraal het vorm en inhoud geven van dit nieuwe paradigma, als uitkomst van de crisis in de medische ethiek. Zelfbeschikking van de patiënt is daarin de nieuwe norm. De één na laatste paragraaf laat de verschillende reacties zien op een probleem, dat niet binnen het gangbare paradigma is op te lossen. Als gevolg van dit probleem, een anomalie, werden er door ethici substituten en alternatieven bedacht voor het concept van zelfbeschikking. Door juristen werd het vraagstuk van levensbeëindiging bij wilsonbekwamen als een dilemma buiten de discussie over euthanasie gezien. Zij vonden dat dit niet binnen de bestaande kaders zou moeten worden opgelost. Tot slot volgt de conclusie van het hoofdstuk waarin medische ethiek wordt geanalyseerd in het licht van wisselende denkstijlen en de gevolgen hiervan voor gezondheidsrecht en gezondheidsethiek. 


\section{Theoretisch kader}

Het begrip denkstijl is afkomstig uit een model voor wetenschapsontwikkeling, waarin het ontstaan en de ontwikkeling van kennis als een sociaal proces worden beschouwd (Fleck 1935; Fleck 1980; Kuhn 1962). Maatschappelijke tendensen zijn van invloed op de ontwikkeling van kennis. Onze kennis is volgens Fleck opgebouwd uit twee onderling verbonden typen elementen namelijk actieve koppelingen en passieve koppelingen. Kennen betekent het vaststellen van de resultaten (passieve koppelingen) die onvermijdelijk zullen volgen bij gegeven voorwaarden (actieve koppelingen). Voor meer passieve koppelingen of het vaststellen van feiten heb je ook meer actieve koppelingen, investeringen in denkstijlen, nodig. Kennis is niet persoonsgebonden, maar groepsgebonden. Ze wordt gedragen door een denkcollectief en vindt zijn neerslag in een specifieke, voor dat collectief meer of minder dwingende denkstijl. Dat wil zeggen, een wijze van denken en handelen waaraan de leden van dat collectief zich niet kunnen onttrekken. Een bepaalde stijl van denken is dus verknoopt met een denkcollectief, vergelijkbaar met het begrip krachtenveld uit de natuurkunde (De Vries 198r).

Fleck heeft zijn sociologische ideeën over kennisontwikkeling in een historische analyse van het syfilisbegrip gedemonstreerd (Fleck 1980). In zijn boek Entstehung und Entwicklung einer wissenschaftlichen Tatsache laat Fleck zien hoe de zogenoemde 'Wassermannreactie', een test voor het aantonen van een syfilisbesmetting in bloed, het toevallige resultaat is van de wisselwerking tussen individu en collectief. Wassermann, een Duitse bacterioloog, werkte aanvankelijk weinig succesvol aan een methode om antigenen aan te tonen in tuberculeuze organen. In 1906 richtte hij zijn aandacht, weer zonder veel succes, op het zoeken van antigenen in het bloed van syfilispatiënten. Hij werd hierin gestimuleerd door mogelijke concurrentie van Franse collega's, die zouden voorlopen in experimenteel-biologisch onderzoek naar syfilis. Wat Wassermann hierbij echter wel, als gevolg van toeval, tot stand bracht was cen test voor het iantonen van syfilis in bloed. Daarmee werd een oer-idee uit de humorenleer wetenschappelijk, na veel werk, verschuivingen en transformaties: het bestaan van syfilitisch bloed was aangetoond. Met andere woorden, oer-idecën genereren inzichten waar men in onderzock wel of niet naar zockt. Dat zickte icts tc maken zou hebben met bloed was de motor achter de ontwikkeling van deze kennis. In de loop van de geschiedenis is het aantal acrieve en passieve koppelingen toegenomen. Volgens Fleck kan kennis alleen toenemen als het aantal actieve koppelingen wordt uitgebreid, maar daar is wel een investering voor nodig. Een investering in de stijl van denken, dat wil zeggen gericht waarnemen en tevens verwerken van wat is waargenomen. Zo wordt een feit gecreëerd, een overeenstemming in een stijl van denken. 
De denkbeelden van Fleck vormden een inspiratiebron voor Kuhn's bekende wetenschapsfilosofische boek The Structure of Scientific Revolutions. Hij heeft, net als Fleck, oog voor de relatie tussen wetenschap en samenleving. Kuhn hanteert een vergelijkbaar model van wetenschapsontwikkeling maar baseert dat niet zoals Fleck op de analyse van één voorbeeld. Hij heeft zijn theorie opgesteld aan de hand van verschillende voorbeelden uit de geschiedenis van de natuurwetenschappen en gaat ervan uit dat er, in kennistheoretisch opzicht, een fundamenteel verschil bestaat tussen periodes van normale wetenschap en periodes van revoluties. In de geschiedenis van de wetenschappen wisselen tijdperken van normale wetenschap en revolutie elkaar af. Tijdens een periode van normale wetenschap bestaat er overeenstemming tussen de leden van een wetenschappelijke gemeenschap over de wijze van onderzoek doen, omdat ze bepaalde ideeën van hun voorgangers als maatgevend beschouwen. Zulke ideeën functioneren als voorbeeld of paradigma voor de manier waarop problemen worden behandeld. Het begrip paradigma is door Kuhn op verschillende manieren omschreven. Dat is enigszins verwarrend, maar toch is het een bruikbaar begrip. In dit hoofdstuk wordt onder paradigma een dominant kader verstaan, dat wil zeggen een verzameling concepten, normen en regels die door een groep wetenschappelijke onderzoekers als leidraad voor hun (onderzoeks)werk wordt genomen. Deze paradigmata zijn achteraf te herkennen door te bestuderen hoe leerboeken binnen een bepaalde wetenschappelijke gemeenschap zijn herschreven, na een periode van revolutie. De leerboeken moeten dan weer op het nieuwe paradigma geënt worden waarna een periode van normale wetenschap volgt. Om een periode van normale wetenschap aan te duiden gebruikt Kuhn de metafoor van 'puzzel oplossen'. De rand van de legpuzzel is al klaar (denkkader), maar de puzzel moet nog verder worden ingevuld. Hoewel Kuhn zijn theorie heeft opgesteld aan de hand van voorbeelden uit de natuurwetenschappen, zou zijn perspectief ook op de sociale wetenschappen toegepast kunnen worden. Immers, wat Kuhn interesseerde was de vraag hoe fenomenen, waarover in artikelen en handboeken wordt geschreven, gevormd zijn door de activiteiten van de onderzoekers van een bepaalde wetenschappelijke gemeenschap. Met andere woorden, de (veranderingen in) denkbeelden en praktijken staan centraal en zijn nier gebonden aan een specifiek type wetenschap.

Naast een aantal overeenkomsten zijn er ook verschillen op te merken tussen Fleck en Kuhn. Bij Kuhn is de disciplinaire matrix verbonden met een bepaalde wetenschappelijke gemeenschap en bij Fleck is de stijl van denken verbonden met het denkcollectief. Maar in tegenstelling tot Kuhn valt het denkcollectief bij Fleck bijvoorbeeld niet samen met een bepaalde gemeenschap. Het denkcollectief wordt niet door een specifieke gemeenschap gevormd, maar kan worden opgesplitst in een kleine esoterische kring (elite) en een grotere 
exoterische kring (massa). Eén persoon kan tot meerdere exoterische kringen behoren, maar slechts tot één esoterische kring.

Een voorbeeld van een paradigma in de betekenis van dominant denkkader voor een bepaalde wetenschappelijke gemeenschap is het idee over medische ethiek als 'gedragscodes', zoals dat in de jaren vijftig en zestig gangbaar was. Medische ethiek is dan voornamelijk een kwestie van beroepscodes voor en door artsen, zoals vastgelegd in de zogenoemde 'blauwe boekjes' van de KNMG (KNMG 1959). Het beeld van de arts-patiëntrelatie dat deze boekjes oproepen is sterk paternalistisch. De arts heeft de wijsheid in pacht en is primair een weldoener of helper in nood. De patiënt is de lijdende mens die hulp behoeft. De patiënt is tevens onwetend in deze; hij wordt niet geacht in staat te zijn keuzes te maken mer betrekking tot zijn eigen gezondheid. Het is de taak van de arts om de patiënt te beschermen tegen ziekte en zichzelf. Een paradigma behelst vaak impliciete beelden die uit de tekst zijn af te leiden; bijvoorbeeld het beeld van de paternalistische arts. "Als de patiënt zou weigeren langer de zorgen van zijn arts te aanvaarden om zodoende het eind van zijn leven te verhaasten, dan blijft de arts geen ander middel over dan de overreding' (KNMG 1959: 15). Het is kennelijk de taak van de arts om de patiënt die verlangt naar het einde van zijn leven op andere gedachten te brengen. Dit moet tegen een achtergrond van het principe van absoluut respect voor menselijk leven worden gezien. De arts werd geacht om alles in het werk te stellen om het leven van de patiënt te behouden. Hij was een vaderfiguur die op grond van zijn kennis en expertise het best wist wat in het belang van de pariënt was. Een patiënt had daar simpelweg respect en ontzag voor, de wens van de patiënt werd niet serieus in overweging genomen. Samen met het principe van absoluuc respect voor leven vormt het beeld van de paternalistische arts de kern van de 'oude' medische ethiek. Het handelen van artsen werd bepaild door dat paradigma, hierover was - onder artsen - algemene overeenstemming.

Dit kun je zien als wat Kuhn noemt een periode van normale wetenschap. Er bestond overeenstemming tussen de leden van een wetenschappelijke gemeenschap over welke begrippen worden gehanteerd om onderwerpen van onderzoek te beschrijven. Men deelde een bepaald mens- en wereldbeeld. Zoals het vorige hoofdstuk heeft laten zien betekende de opkomst van reanimatie- en beademingstechnieken en transplantatiemogelijkheden een omslag in het medischethisch denken over leven en dood. Door de nieuwe technieken waren artsen in staat om veel verder door te behandelen dan voorheen. Naast grote successen betekende dit ook dat het sterfbed van sommige patiënten aanzienlijk werd verlengd. Men moest enigszins gaan forceren om deze nieuwe categorie patiënten - de 'hartlongpreparaten' en de 'decerebranten' - in het gangbare medischethische kader te gaan inpassen. ' De absolute interpretatie van het respect voor menselijk leven stond onder grote spanning. ${ }^{4}$ Er was sprake van een niet-passend 
stukje in de purzel waar de betrokkenen zich vanuit hun paradigma geen raad mee wisten; cen anomulie. Dat wil zeggen dat de vertrouwde en algemene aanpak van de nieuwe problematiek tekorr schoot. Kortom, er was sprake van een crisis in de medische ethiek. 'Door diverse betrokkenen werden alternatieven gegeven voor deze leidraad van her medisch handelen (Van den Berg 1969; Prick 1969b; Van den Hoofdakker 1970).

I)eze fase kan, in termen van Kuhn, als cen revolutie gekarakteriseerd worden. In cen periode van crisis wordt erkend dat het voorheen geaccepteerde denkkader niet meer voldoet. Het oude paradigma, het vaste oriëntatiepunt, valt weg. Er bestaat geen overeenstemming meer over hoe het dilemma - in dit geval het probleem van de medische macht ${ }^{6}$ - moet worden aangepakt. Een nieuw kader daarentegen is niet direct voorhanden. Het ontbreekt aan vaste criteria om beslissingen te nemen in een periode van revolutie. In deze fase is er ruimte voor (nieuwe) denkstijlen, bijvoorbeeld meer liberale houdingen ten opzichte van leven en dood, om zich te ontwikkelen. Het keurslijf van een richtinggevend paradigma ontbreekt. Het disciplinaire denken staat nu meer open voor maatschappelijke invloeden; denkstijlen zijn dan van grotere betekenis.

$\mathrm{Na}$ cen revolutionaire fase breekt weer een periode van normale wetenschap aan, waarin een nieuw paradigma als overkoepelend denkkader functioneert. In het debar over vragen rond het levenseinde is niet meer het absoluut respect voor leven - waarin het biologische leven de standaard is - de leidraad, maar het respect voor menselijk leven dat als zinvol wordt ervaren. De arts die standaard doorbehandelt als er nog alternatieve behandelingen mogelijk zijn, maakt plaats voor een nieuwe arts-patiënt verhouding bij het nemen van beslissingen. In die nieuwe verhouding staat de communicatie tussen arts en patiënt voorop. Een nieuw paradigma, waarin de autonomie van de patiënt centraal staat, wordt gevormd. Zoals we in het vorige hoofdstuk hebben gezien breekt weer een revolutionaire fase aan, op het moment dat het onderwerp van levensbeëindiging en wilsonbekwamen - voor sommigen een anomalie - op de agenda komt te staan. Het idee van de autonome patiënt biedt daarvoor geen oplossing meer.

In dit hoofdstuk wordt met behulp van de ideeën van Fleck en Kuhn de vraag behandeld hoe de noties van autonomie en zelfbeschikking zo centraal zijn komen te staan bij de disciplines gezondheidsethiek en gezondheidsrecht. Net als in de andere twee empirische hoofdstukken heeft het theoretisch kader een heuristische functie, het aanscherpen van of aanvullingen leveren op de theorie is dus geen doel op zich. Het gaat om inzicht verwerven in de ontwikkeling van en relatie tussen gezondheidsrecht en gezondheidserhiek. 


\section{Twee denkstijlen}

\section{De patiënt en het naderend einde}

Als een patiënt vandaag de dag in Nederland een uitgesproken euthanasiewens heeft, laat hij of zij dit soms al ver van te voren weten aan de huisarts. De uiting van deze wens kan eventueel ondersteund worden door een schriftelijke wilsverklaring. Deze praktijk, waarin het initiatief van de patiënt uitgaat, staat in schril contrast met het beeld van de arts-patiëntrelatie van vijftig jaar geleden. Als het om een naderend einde ging was het geenszins vanzelfsprekend dat een patiënt daar weet van had, laat staan initiatieven ontplooide. Normaal gesproken werd niet de volledige waarheid omtrent de gezondheidstoestand aan de patiënt uit de doeken gedaan. Een arts was geneigd om door te behandelen, vanwege de notie 'absoluut respect voor leven', wat betekende dat het leven een absolute waarde in zich zelf had. De focus was volledig op het lichamelijk functioneren van de patiënt gericht en een arts deed er meestal het zwijgen toe omtrent de ware aard van de situatie. Hij bood bemoedigende woorden en vooral troosr. De mogelijkheid voor een patiënt om een behandeling te weigeren was er alleen in theorie. Deze paragraaf laat zien hoe de rol van de patiënt verandert in de context van de (inperking van de) medische beslissingsmacht. De paragraaf begint met her openbreken van het paradigma van medische ethiek als gedragscodes en eindigt met een zekere consensus over de definitie van euthanasie.

Mede als gevolg van de ontwikkelingen in de medische wetenschap kwam her gangbare paradigma, waarin de patiënt vaak niet volledig werd ingelicht over zijn situatie, in een ander daglicht te staan. 'De diagnostiek is dusdanig verscherpt door röntgenonderzoek, biopsie en biochemische reacties dat men veel langer tevoren de ongunstige afloop kan voorzien, soms jaren te voren bij patiënten, waarbij men vroeger nog geen verdenking koesterdc. En dan niet te vergeten, dat ook door transfusies, antibiotica, celremmende stoffen en operaties een definitief ongunstig verloop veel langer kan worden regengehouden en het ziekbed vaak zeer lang wordt gerekt. Dit alles overziende (...) is het geen wonder (...) dat deze omstandigheden voor onze tijd speciale problemen oproepen, vooral ten aanzien van de waarheid aan het ziekbed (...)' (Brenninkmeijer 1957: II4). De dood kon door de diverse ontwikkelingen worden uitgesteld en kwam - voor de arts - in sommige gevallen minder onverwacht dan voorheen. Niettemin was men niet onmiddellijk geneigd om nu maar open kaart te spelen met de patiënt bij een naderend einde. Slechts in uitzonderingsgevallen, wanneer het evident (psychisch) schadelijk zou zijn voor de patiënt om niet op de hoogte te zijn van zijn situatie, zou van de standaard kunnen worden afgeweken (p. II5). Dit veranderde geleidelijk. Vanaf de jaren zestig werd steeds vaker de patiënt als persoon opgevoerd in de relatie arts-patiënt rond levensbeëindigend handelen. 
In diverse artikelen en boeken ging het om de patiënt als authentieke persoon, de patiënt als belanghebbende, of de patiënt als eigen verantwoordelijke. Er werd aandacht gevraagd voor het belang van de patiënt als het ging om diens rol en positie bij vraagstukken rondom het levenseinde. Dit werd expliciet gedaan, terwijl het voorheen impliciet werd verondersteld. Ten opzichte van het oude paternalistische paradigma leek aandacht voor 'het belang van de patiënt' namelijk op het eerste gezicht een kwestie van oude wijn in nieuwe zakken. Het doel van medisch handelen was immers altijd op het belang van de patiënt gericht. Maar onder het mom van dit zelfde argument, het belang van de patiënt, werd wel voor vernieuwing gepleit. Deze 'vernieuwing' kan als een symptoom van de heersende crisis beschouwd worden. In een periode van normale wetenschap staat het vanzelfsprekende niet ter discussie, maar in een periode van crisis komt dat juist op de agenda te staan. Bekend veronderstelde zaken worden dan onderwerp van debat. De literatuur in deze periode had dan ook een zoekend karakter, zoals ook uit het vorige hoofdstuk al is gebleken.

In de crisisperiode van de medische ethiek ontwikkelden zich aanzetten tot grofweg twee verschillende denkstijlen die als sociaal-levensbeschouwelijk en individueel-humanistisch gekarakteriseerd kunnen worden. Vanuit enerzijds een sociaal-levensbeschouwelijke en anderzijds een individueel-humanistische denkstijl werd geprobeerd ecn oplossing te vinden voor het probleem van de 'medische macht' (paternalisme in de geneeskunde). Die oplossingen verschilden in een aantal oprichten. Het focus van de sociaal-levensbeschouwelijke denkstijl was gericht op de arts-pariëntrelatie binnen een maatschappelijke of sociale context. De diepgang in de afhankelijkheids- of vertrouwelijkheidsrelaric tussen arts en patï̈nt was van belang, niet afhankelijkheid in de zin van een paternal iscische relatic, maar een wederzijdse afhankelijkheid. Om tot cen goed eindresultaat te komen was de inzet van zowel arts als patiënt vereist. De arts kon de patiënt niet los van zijn omgeving beschouwen. De gezondheidstoestand van de patiënt was op vele manieren verbonden met andere elementen in diens leven. Juist dat geheel was van belang. Het ging om aandacht voor de patiënt als mens en bron van zingeving, niet alleen als lichamelijk object.

De sleutelauteur van de sociaal-levensbeschouwelijke denkstijl was de katholieke moraaltheoloog Sporken. Vanaf midden jaren zestig heeft hij intensief vanuit een ethisch-religieus perspectief in het debat over levensbeëindigend handelen geparticipeerd. De patiënt werd door hem als een 'authentieke totaliteit' gezien. Het ging om de totale mens achter de patiënt. Binnen deze, op de mens in zijn sociale context gerichte, ethiek was er ruimte voor levensbeëindigend handelen, maar alleen in relatie tot de stervensbegeleiding. Het einde van het leven werd als een belangrijk onderdeel van de levensopgave beschouwd (Sporken 1965b). Euthanasie was voor Sporken dan ook een vorm van stervenshulp voor de patiënt in de stervensfase. Van de arts werd verwacht dat hij zijn 
patiënt hielp om een zinvolle betekenis te vinden in de dood (Sporken 1969b: 207). Binnen dat uitgangspunt was pijnbestrijding met een vervroegde dood als bijgevolg te legitimeren. Want het ging om het behoud van menselijk leven, en niet om het behoud van biologisch leven. Menselijk leven betekende per definitie zinvol leven en als dat niet meer mogelijk was, zou het zaak zijn om het sterven zo zinvol mogelijk te maken. Ingrijpen in het stervensproces zou alleen mogen als dit 'zin' had. 'Wat dit laatste betreft: men mag dit alleen doen als het zin heeft voor de patiënt, hetzij vooral voor hemzelf, hetzij vooral voor zijn omgeving' (Sporken 1972c: 90). Zin werd kennelijk niet alleen uitgelegd als betekenis hebbend voor de patiënt, maar strekte zich verder uit naar de sociale context van de patiënt.

Deze gedachte kwam echter niet alleen uit een katholiek-moraal-theologische tradirie voort. Het begrip authentieke humaniteit van Sporken was ook terug te vinden onder de noemer 'het humanum'. Het ging om de mens in een teleologisch-levensbeschouwelijke context; de mens had een bepaalde bestemming in zijn leven. Die bestemming kon niet alleen het behoud van biologisch leven zijn. Het behoud van menselijk leven stond centraal, waarbij 'menselijk' veelal werd ingevuld als een 'minimum aan menselijk reactievermogen of communicatie' (Heering 1971). Om morele ruimte te creëren voor de mogelijkheid van euthanasic interpreteerde de protestant Heering een uitspraak van Paulus. ' Is het fout deze uitspraak te interpreteren als: de mens heeft het beschikkingsrecht over zijn leven en dood, mits in gemeenschap met Christus en God? Seculier is dit te vertalen als: de mens heeft het beschikkingsrecht over leven en dood, mits niet in eigenzinnigheid maar in volle verantwoordelijkheid ten aanzien van zijn plaars onder de mensen?' (Heering 1977: 22). Een (seculiere) interpretatie maakte her Heering mogelijk om ruimte te scheppen voor een oordeel over leven en dood. De mens werd nadrukkelijk in relatie met zijn sociale context beschouwd. Soms met een specifieke verwijzing naar het beeld dat de patiënt verbonden zou zijn met verleden en toekomst zoals bij de arts Prick (Prick 1969b: 83). Het begrip 'medemenselijkheid' kwam telkens terug. Mens-zijn werd opgevat als medemens zijn (Schillebeeckx 1968: 36r). En dat gold ook voor de arts. De arts diende de patiënt naast wetenschappelijk 'ook menselijk te benaderen, waarbij hij zijn eigen religieuze overtuiging niet zal kunnen buiten sluiten' (Van der Meer 1971: 20). Euthanasie - in brede zin - werd aldus alleen mogelijk beschouwd als onderdeel van de stervensbegeleiding. De stervensbegeleiding vormde een vast onderdeel van de 'totale zorg voor de patiënt' (Van Es 1977). Daarin waren (huis)arts en patiënt samen verantwoordelijk. Het was de taak van de arts, om door het geven van stervenshulp, de patiënt uit zijn isolement te halen.

Binnen de individueel-humanistische denkstijl werd de patiënt voornamelijk als een verantwoordelijk persoon beschouwd. De mens was zelf verantwoordelijk voor zijn leven en moest ook op zijn eigen geweten vertrouwen. Daarbij had 
hij bepaalde rechten die hem zouden kunnen helpen bij het maken van verschillende keuzes in het leven. De dood was dan ook als een keuze te beschouwen, een individuele keuze. De arts-patiënt relatie kon het best als een contractuele relatie worden omschreven. Arts en patiënt stonden in een zakelijke verhouding tot elkaar. In plaats van wederzijds vertrouwen bestond de basis van deze relatie uit een spel van wederzijdse rechten en plichten. De eerste auteur die primair vanuit een dergelijk perspectief op vragen rond leven en dood reflecteerde was de juriste Van Till. Zij pleitte voor het recht op het onverstoorde sterven (Van Till-d'Aulnis de Bourouill 1970: 26). Dit recht werd het patiëntenaspect van de euthanasie genoemd. In aansluiting op een verwijzing naar de arts Prick en de ethicus Sporken nam ook Van Till afstand van het 'oude' beeld van de arts: 'De arts magiër, die alles wist (...)' (p. 49). ${ }^{8} \mathrm{Bij}$ het sterven van de patiënt zou gelden: 'De arts is de helper van de patiënt, niet zijn meester' (p. 28). De patiënt was de enige die bij kwesties rondom het levenseinde een beslissing kon nemen. Van Till stelde dat ouders, voogden, curators en familieleden geen enkel 'juridisch recht' hadden om over het leven van een betrokkene te beslissen (p. 104). Het initiatief voor weigering van (levensbehoudende of -reddende) behandelingen lag - in tegenstelling tot de sociaal-levensbeschouwelijke denkstijl - voor de volle honderd procent bij de patiënt. 'Wanneer echter een patiënt bewust wil sterven, heeft de patiënt zelf de keus gemaakt in het conflict van mogelijkheden en normen. Het probleem dat aan de orde is lijkt mij namelijk een probleem van keuze; de keuze van de patiënt of hij wel of niet een vertragen van zijn sterven wenst' (p. 29). Vragen van leven en dood zouden dus kennelijk voorheen, volgens Van Till, vanuit een onjuist perspectief zijn beoordeeld en behandeld.

Vanuit het individueel-humanistisch perspectief ging het niet om de vraag ofbeëindiging van menselijk leven geoorloofd was, maar wanneer dit wel of niet het geval was. Het beslissende criterium hierbij was de zin van het eigen leven (Ekelmans 1971: 792). Het perspectief van de 'mondige sterveling' vormde het uitgangspunt bij deze denkstijl (Ekelmans 1971). Het 'mondige' had betrekking op het idee dat de mens zelf dacht en besliste en ook zelf verantwoordelijk was, in plaats van een 'hemelse curator' (p. 794). Het rechtenperspectief van de patiënt werd ontleend aan een algemene ontwikkeling van de mensenrechten, binnen de context van de gezondheidszorg. Het zelfbeschikkingsrecht van de mens zou hierin centraal staan (Leenen 1977). 'Eerbied voor het leven betekent niet dat men, zelfs via wetgeving, mag gaan bedillen over zaken die slechts de individuele persoon en zijn geweten aangaan; eerbied voor het leven houdt in eerbiediging van de vrije beschikking van de mens over zichzelf (p. 77). Het principe van absoluut respect voor leven kreeg hier dus een andere berekenis.

In aansluiting op Van Till leverde Leenen in de jaren zeventig het exemplarische denkkader voor de nadere uitwerking van deze individueel-humanistische denkstijl, maar het waren niet alleen juristen die zich van dit vocabulaire be- 
dienden. Juristen waren dan wel opgevoed met het idee van rechten en plichten, maar ook diverse artsen en filosofen bouwden mee aan deze denkstijl. Zo stelde de arts De Lange dat bij het reanimatievraagstuk 'de patiënt baas over eigen lichaam' zou zijn. Dat wil zeggen dat de patiënt alle aan hem voorgestelde behandelingen kon weigeren (De Lange 1964). Iedereen zou het recht moeten hebben zelf de balans van het leven op te maken. Dat betekende geen onderscheid tussen een levensverkortende behandeling (actieve euthanasie) en het nalaten van een levensverlengende behandeling (passieve euthanasie). De zelfstandigheid en vrijheid van de mens stonden aldus centraal. Zodat ook de 'beeindiging van zijn leven voor de mens een moreel verantwoorde existentiële daad kan zijn' (Klever 1970: 8). De filosoof Klever pleitte voor een ethiek waarin de rechten, belangen en wensen van de patiënt centraal stonden (p. io).

Achteraf is het dus mogelijk om twee van elkaar te onderscheiden denkstijlen te definiëren. Het gros van de auteurs in deze periode kan onder één van beide denkstijlen geschaard worden, maar niet elke auteur valt ondubbelzinnig te karakteriseren. Enerzijds is er soms sprake van dat het werk van één auteur ingrediënten van beide denkstijlen bevat. Anderzijds kan het ook zo zijn dat aureurs dezelfde begrippen gebruiken, maar dat de betekenis ervan zoals dit tot uitdrukking komt in het gebruik, verschilt. Het eerste, de dubbele denkstijl, kan aan de hand van de arts Van den Berg worden geïllustreerd. Hij zou zowel binnen de individueel-humanistische denkstijl als de sociaal-levens-beschouwelijke denkstijl kunnen vallen. Enerzijds zag hij sommige patiënten als 'slachtoffers van de medische macht'. Dit leidde tot een pleidooi voor de waarheid op tafel. 'Uit het voorgaande blijkt, dat ik opening van zaken aanbeveel, in beginsel voor ieder, en op elk moment. De patiënt heeft het recht te horen waar hij aan toe is, op elk door hem gewenst moment. De arts heeft de plicht te vertellen wat hij vond, wat hij ervan denkt en wat hij denkt te doen, op elk beslissend moment' (Van den Berg 1969: 35). Het beslissende oordeel inzake leven en dood kon door de patiënt worden uitgesproken. Anderzijds, in gevallen waarin dat niet mogelijk was zoals bij pasgeborenen, kinderen, comateuzen en demente bejaarden, werd de beslissing door de arts genomen. Dit kon eventueel in overleg met ouders of een partner gebeuren. Een oordeel over de zin van het leven kon dus door derden worden genomen. 'Wie beslist wat wel en niet zinvol is? Een commissie schreef $i k$, een kleine commissie, ik liet nog in het midden uit welke leden de met nadruk kleine commissie moet zijn samengesteld' (p. 47). De nieuwe medische ethiek, waarin actieve levensbeëindiging mogelijk en volgens hem soms zelfs wenselijk was, ging kennelijk boven het laatste woord door de patiënt. Van den Bergs betoog bevatte daarmee elementen van beide later uitgekristalliseerde denkstijlen.

Als alleen taal of woorden worden bestudeerd, dan zouden stukken van Sporken ook vanuit een individueel-humanistisch perspectief geïnterpreteerd 
kunnen worden. Zo stelde Sporken bijvoorbeeld dat het vraagstuk over de waarheid met betrekking tot ziekte en gezondheid omstreden was: 'ze [wordt] ook vaak ter sprake gebracht in de context van de mondigheid van de patiënt en van zijn rechten op inspraak bij de te ondernemen behandeling' (Sporken 1972c: 66). Volgens Sporken zou de patiënt dan ook het recht moeten hebben om de waarheid te vernemen. Het gebruik van een bepaald vocabulaire - bijvoorbeeld rechten - is echter niet voldoende motivatie bij een interpretatie van denkstijlen. De context van het stuk, (eventueel in samenspraak met andere stukken van dezelfde auteur), is relevant om te bepalen wat de betekenis van een uitspraak en argument is. Bij Sporken wordt uit de context duidelijk dat de patiënt zeker niet los van zijn omgeving mag worden beschouwd.

De gemene deler bij beide denkstijlen is dat het belang van de patiënt op specifieke wijze op de agenda wordt geplaatst. Dat wil zeggen dat beide denkstijlen afscheid nemen van de paternalistische betekenis waarin beslissingen werden genomen vanuit een impliciet idee over 'in het belang van de patiënt'. Het idee dat de arts automatisch zou weten wat goed is voor zijn patiënt - dat wil zeggen dat hij interpreteert op basis van zijn kennis, ervaring en sociale positie en daarmee het belang van de patiënt kan behartigen - werd ter discussie gesteld. In de nieuwe betekenis moest de patiënt duidelijk en bij voorkeur door hem zelf gearticuleerd belang hebben, in de zin van betrokken zijn, bij de beslissing. De invulling van dit nieuwe 'belang van de patiënt' binnen de context van levensbeëindigend handelen verschilde echter. Binnen de ene denkstijl werd de patiënt in zijn sociale (levensbeschouwelijke) context gezien, waarin beslissingen als zingevingkwesties werden beschouwd binnen een breed overleg, van arts, patiënt en familie. Binnen de andere denkstijl werd de patiënt als individu met particuliere rechten gezien, die alleen zelf dergelijke beslissingen kan nemen. De volgende paragraaf gaat in op de vraag hoe één van deze twee denkstijlen dominant kon worden.

\section{Het verzoek van de patiënt}

Perioden van crisis zijn een belangrijk signaal voor het ontstaan van nieuwe theorieën en denkstijlen. Hoewel velen hun geloof in het oude paradigma langzamerhand verloren en aan alternatieven dachten, lieten ze dat echter niet onmiddellijk vallen. Het is niet zo dat er meteen sprake is van een breuk. Het oude paradigma kwam juist meer op de achtergrond te staan door de verfijningen die werden aangebracht. Het beeld van de alwetende paternalistische arts verdween langzaam maar zeker door de introductie van de 'vertrouwensrelatie' tussen arts en patiënt (arts en patiënt meer als mensen onder elkaar) of de 'contractuele' relatie tussen arts en patiënt. Over de patiënt werd steeds meer gesproken als een persoon met behoeften, belangen en rechten. Tenslotte werd 
het principe van absoluut respect voor leven verfijnd door het te vertalen naar respect voor menselijk leven of respect voor zinvol leven.

Met de crisis in de medische ethiek werd het beeld van medische ethiek als gedrags- of beroepscodes steeds minder gangbaar. Er gingen geluiden op dat, omdat de mens veranderde, ook de ethiek mee zou moeten veranderen. Vanaf begin jaren zeventig verscheen er een groot aantal beschouwingen over de vrijheid en de mondigheid van de mens. Deze ideeën, waarin aan de wens en keuze van de patiënt nadrukkelijk aandacht werd besteed, werden beschouwd als de uitkomst van een zeer geleidelijk proces. Er werd een lange trits genoemd. 'Deze bewustwording van de autonomie van de persoon is een zeer geleidelijk proces geweest. Daarbij hebben de antieke filosofie en wetgeving, het christendom met zijn accent op persoonlijke levensroeping, renaissance, humanisme en reformatie, de latere filosofie sinds Kant, de ontwikkeling van wetenschap en techniek, de Franse revolutie, het liberalisme en de moderne democratie, het marxisme met zijn ontmaskering van onvrijmakende structuren het modern existentialisme alle hun betekenis gehad, of hebben die betekenis nog steeds' (Nederlands Gesprek Centrum 1975: 4I). Dit leidde mede tot een moreel recht op zelfbeschikking. 'Tegen deze achtergrond is het probleem van de euthanasie een test-case geworden inzake het verstaan van het morele recht op zelfbeschikking. Kan ook het leven zelf volledig, principieel en onathankelijk als inhoud van die zelfbeschikking worden verstaan?' (Nederlands Gesprek Centrum 1975: 42). Volgens Dupuis waren de beschouwingen over mondigheid op te varten als een verzet tegen de toenemende medische macht in de geneeskunde (Dupuis 1976). Zij pleitte voor een ethiek van de mondige mens, die zou moeten leiden tot nieuwe normatieve richtlijnen voor het handelen van artsen. Er heerste een algemeen gevoel dat het traditionele idee van medische ethiek faalde bij de aanpak van de nieuwe problemen. Een deel van de betrokkenen probeerde ideeën te ontwikkelen om om te gaan met het gevoel van onbehagen in de medische ethiek.

Zoals ook in het vorige hoofdstuk over de definiëring van euthanasie is besproken, was er aanvankelijk geen consensus onder artsen, ethici en juristen over wel of nier ingrijpen in het stervensproces. Het oude paradigma, waarin ethiek een vorm van gedragscodes was, werd gekenmerkt door de afwezigheid van discussies over levensbeëindiging. Dit type thema was niet bespreekbaar in verband met het absoluut respect voor leven. Er gold een paternalistische houding om met dilemma's rond het levenseinde om te gaan. Binnen de aanzet tot de sociaal-levensbeschouwelijke denkstijl werd levensbeëindiging veelal wél als mogelijk beschouwd, maar alleen als laatste fase van de stervensbegeleiding. Dat betekende dat het een optie was, dan en slechts dan, als de stervensfase eenmaal was aangebroken. Binnen de aanzet tot de individueel-humanistische denkstijl gold deze beperking niet. Het ging om menselijk en zinvol leven, ook buiten de stervensfase kon sprake zijn van niet menselijk of niet zinvol leven. De 
strikte interpretatie van respect voor leven was losgelaten en dit betekende dat er in beide denkkaders .. de sociaal-levensbeschouwelijke en de individueelhumanistische - van een verantwoordelijkheidsprobleem sprake was. Als het principe van absoluut respect voor leven niet onverkort gold, uie bepaalde dan uarine' $r$ het nietgold? Volgens de sociaal-levensbeschouwelijke denkstij] waren hiervoor - binnen de stervensfase - meerdere mogelijkheden: de arts, de arts in overleg met een collega of pastor of in overleg mer de patiënt en eventuele familie. Vonrop stond dat in alle gevallen de patiënt er belang bij moest hebben, maar er was ruimte voor een gesprek over de invulling van dat belang met anderen. Binnen de individeel-humanistische denkstijl was de patiënt de enige die hierover een beslissing kon nemen. Deze beslissing was niet beperkt tot de terminale fase. Het is duidelijk dat er sprake was van een conflict. Ideeën over welke normen moesten prevaleren botsten.

In discussies over wat nu wel of geen euthanasie is, werd dit conflict verder uitgevochten. Her ging in deze discussie om een drietal vragen of problemen: om wat voor soort beslissingen gaat het hier, welke normen zijn daarbij in het geding en wie heeft de verantwoordelijkheid? Bij de beantwoording van de vraag naar euthanasie stonden de rol van de arts, de verhouding tussen arts en patiënt en de positie van de patiënt zelf ter discussie. Om principiële en strategische redenen werd er onderscheid gemaakt in verschillende soorten euthanasie. Hierdoor raakte het euthanasieprobleem verkaveld. ${ }^{9}$ Het idee dat euthanasie een brede categorie van handelingen was, werd losgelaten. Dit had consequenties voor de 'geldigheid' van de twee denkstijlen. Leenen deed een voorstel om dit drievoudige probleem met één analytische ingreep op te lossen. Eind jaren zeventig betoogde hij dat er onderscheid gemaakt moest worden tussen euthanasie en schijngestalten van euthanasie. Onder schijngestalten van euthanasie verstond hij een aantal problemen rond het levenseinde die volgens hem wél op euthanasie leken, maar dit niet waren. ${ }^{\circ}$ Dit zou vanuit zijn perspectief' 'normaal medisch handelen' zijn. Hij noemde: het staken van een zinloze medische behandeling, 'euthanasie' bij pasgeborenen, indirecte 'euthanasie', het stoppen van de verzorging van een hersendode, het weigeren van medische behandeling en een noodtoestand bij gebrek aan middelen (Leenen 1978). Centraal in zijn betoog stond het verschil tussen de zin van het leven en de zin van het medisch handelen. Leenen stelde, op grond van her zelfbeschikkingsrecht van de mens, dat iedereen voor de wet gelijk was en het leven van de één niet zinvoller was dan dat van een ander. Niemand, ook een arts niet, was dus goed genoeg om over het leven van een ander te oordelen. Een patiënt oordeelde zelfover de zin van zijn leven. Een arts kon alleen de zin van het medisch handelen bepalen. Dat gebeurde uitsluitend aan de hand van medische criteria. ' $D e$ arts had alleen te maken met de wil van de patiënt en in het geval van een zinloze medische behandeling met zijn eigen medisch inzicht en oordeel' (p. 24I). 
Het onderscheid tussen de zin van het leven en de zin van het medisch handelen betekende dat er bij beslissingen rond het levenseinde niemand anders dan de arts en de patiënt van belang waren. Dit waren de enige twee partijen die een stem in het kapittel hadden; de arts bij vragen van normaal medisch handelen (de schijngestalten van euthanasie) en de patiënt bij de 'smalle' euthanasie (levensbeëindiging op verzoek). Het idee van het brede overleg bij dit soort beslissingen - bijvoorbeeld 'multidisciplinaire commissies' of overleg met de familie zoals dat in de sociaal-levensbeschouwelijke denkstijl was verwoord was geen optie. Immers, niemand anders dan de patiënt kon over de zin van zijn leven oordelen en niemand anders dan de medicus kon over de zin van het medisch handelen oordelen, zo luidde het uitgangspunt. Het verzoek voor euthanasie kon dan ook alleen van de patiënt afkomstig zijn. De kern van Leenens betoog berustre op het zelfbeschikkingsrecht van de mens en het strikte onderscheid tussen waarde-oordelen en medisch-professionele oordelen (die door Leenen als objectief werden beschouwd). Het onderscheid tussen euthanasie en schijngestalten van euthanasie aanvaarden, betekende ook het accepteren van deze twee uitgangspunten. Het element 'op diens verzoek' in de definitie van euthanasie was, gezien het bovenstaande, dan ook cruciaal. In de volgende paragraaf worden de reacties op het voorstel van Leenen beschreven.

Het oude paradigma van medische ethiek als gedragscodes bleek niet toereikend te zijn voor het interprereren, beschrijven en daarmee oplossen van de problematiek rond de nieuwe categorie patiënten - de steeds maar doorbehandelde patiënten waarvan eerder het sterfbed dan het leven werd verlengd. Achteraf zijn er twee nieuwe, concurrerende denkstijlen te onderscheiden, die in deze periode opkomen. Deze zijn omschreven als de sociaal-levensbeschouwelijke en de individueel-humanistische denkstijl. Bij beide denkstijlen stond expliciet het belang van de patiënt, als antwoord op de toenemende medisch macht, centraal. Hoewel bij de eerste denkstijl degene die tot sleutelfiguur is aangewezen een erhicus was en bij de twcede een jurist, waren de twee denkstijlen in deze tase toch niet exemplarisch voor de gezondheidsethick cner rijds en het gezondheidsrecht anderzijds. Beide denkstijlen werden door zowel artsen, ethici als juristen vertegenwoordigd. Ze onderscheidden zich in de wijze waarop levensbeëindigend handelen al dan niet gcoorloofd werd geacht.

\section{Een paradigma: de autonome patiënt}

\section{Bitekcnis van bet concept zelfbeschikking}

De beslissing tot levensbeëindigend handelen was binnen de sociaal-levensbeschouwelijke denkstij] pas mugelijk als de stervensfasc was aangebroken en 
kon door een breed overleg worden genomen. Volgens de individueel-humanistische denkstijl gold de beperking van de stervensfase niet. Het ging om een individuele keuze van de patiënt, deze keuze was niet gebonden aan de terminale fase. De introductie van het onderscheid tussen de beoordeling van de zin van het leven en de zin van het medisch handelen werkte uit ten voordele van de laatste denkstijl. De acceptatie van dit onderscheid - alleen de patiënt kan oordelen over de zin van zijn leven en alleen een arts kan op grond van medisch (objectieve) criteria oordelen over de zin van het medisch handelen - was niet verenigbaar met het idee van een breed overleg bij beslissingen rond het levenseinde. Het betekende tevens dat de eis dat dit alleen mogelijk is tijdens de stervensfase sterk aan kracht verloor. Het was immers niet primair relevant wanneer een dergelijke beslissing werd genomen, maar door wie. Als het over de vraag naar de zin van het medisch handelen ging, dan besliste de arts en als het om een oordeel over de zin van het leven gaat, dan besliste de patiënt. Het belang van de patiënt was dus vertaald naar het zelfbeschikkingsrecht van de patiënt. In deze paragraaf wordt duidelijk dat het idee van zelfbeschikking van de patiënt, dat voortvloeit uit de individueel-humanistische denkstijl, de kern gaat vormen van het nieuwe paradigma voor de medische ethiek.

Volgens velen beloofde het idee van de mondige patiënt, de patiënt die zelf (ook) zeggenschap heeft inzake beslissingen rond het levenseinde, de meeste problemen van het oude paradigma op te lossen. Die belofte hoefde overigens niet volledig te worden ingelost vóórdat het oude paradigma van de ethiek kon worden losgelaten. Alom werd erkend dat er grote problemen waren die om een oplossing vroegen. Rond het levenseinde was dat primair het probleem van de toenemende medische (beslissings)macht, met in het voetspoor de categorie van de (te) ver doorbehandelde patiënten. Van het weigeren van een behandeling was in het oude paradigma geen sprake, omdat een patiënt een passieve rol had en vaak niet wist wat er werkelijk aan de hand was. Een periode van crisis, zoals beschreven in de vorige twee paragrafen, veranderde het paradigmatische denkkader van de actoren. Vervolgens brak er een periode van relatieve rust aan, waarin aan het inlossen van de belofte - het paradigma van de mondige patiënt - werd gewerkt. Het gangbare werk werd erkend als grondslag voor nieuw denken. Het werk dat door ethici en juristen werd verricht om het nieuwe paradigma invulling te geven kan als 'puzzelen' worden gekarakteriseerd. De rand van de puzzel - zelfbeschikking als dominant denkkader - kreeg vastere vormen doordat bijvoorbeeld juristen en ethici zelfbeschikking steeds meenamen in hun (soms kritische) beschouwingen over euthanasie of dat ze probeerden de toepassing van zelfbeschikking verder in te vullen. Het gemeenschappelijke paradigma kreeg een dusdanige vanzelfsprekendheid, dat onderlinge verschillen van een tweede orde waren. Het waren conceptuele puzzels en afbakeningspuzzels, die werden aangepakt en 'opgelost'. Daarbij werd regelmatig verwezen 
naar passages over zelfbeschikking en schijngestalten van Leenen uit de vorige paragraaf (overigens werd er andersom - juristen naar ethici - aanzienlijk minder vaak verwezen). Passages van Leenen verkregen de functie van exemplarisch voorbeeld of ankerpunt in de discussie over euthanasie en zelfbeschikking. ${ }^{12}$

De juriste Roscam Abbing besteedde in haar oratie aandacht aan de reikwijdte van het zelfbeschikkingsrecht. Ze verkende het zelfbeschikkingsrecht als juridisch concept. Het recht op zelfbeschikking zou, samen met de medischprofessionele standaard, één van de pijlers zijn waaraan het medisch handelen gebonden was (Roscam Abbing 1983). Bij euthanasie ging het volgens Roscam Abbing niet om de vraag óf het zelfbeschikkingsrecht aan de orde was, maar tot hoever het zelfbeschikkingsrecht reikte (Roscam Abbing 1985b: 49). Ze was van mening dat dit recht deed aan de verschuivingen in maatschappelijke opvattingen rondom het sterven. Op een euthanasiesymposium twee jaar later stelde Roscam Abbing dat de rechten van de mens centraal stonden bij een fundamentele beschouwing over euthanasie. Met name het recht op leven, recht op onaantastbaarheid van het menselijk lichaam en het recht op bescherming van de persoonlijke levenssfeer stonden volgens haar voorop. Ze volgde hiermee Leenen in zijn handboek Rechten van mensen in de gezondheidszorg. Volgens Roscam Abbing was er sprake van een scheve situatie bij het zelfbeschikkingsrecht. Het recht erkende namelijk dat een mens het recht tot levensverkorting niet ontzegd kon worden in geval van weigering van toestemming om een medische behandeling te ondergaan. Daarop voortredenerend stelde Roscam Abbing dat dan ook een recht op levensverkorting in geval van verzoek mogelijk zou moeten zijn. Zij was van mening dat als men handelen (inclusief nalaten) in het kader van toestemming accepteerde, men ook handelen (inclusief nalaten) in het kader van een verzoek zou moeten accepteren, ondanks een juridisch verschil tussen deze twee mogelijkheden (p. 54). Het concept zelfbeschikking zou dus verbreed moeten worden. Met een beroep op het argument van logica - als je in het ene geval zelfbeschikking legitimeert, is dat in het andere geval ook logisch - verkende Roscam Abbing de inhoud en reikwijdre van dit concept. Voor haar waren er geen twijfels over de vraag of zelfbeschikking uitgangspunt was, de bredere toepassing ervan stond kennelijk centraal.

Naast het bepalen van de reikwijdte van zelfbeschikking, vormen ook het vorm en inhoud geven aan het karakter en de status van het idee van zelfbeschikking een aspect van de fase van het puzzelen. De ethicus/theoloog Kuitert was bezig een conceptuele kwestie uit te werken toen hij probeerde duidelijk te maken, dat het bij zelfbeschikking om een moreel probleem ging. Een moreel probleem dat volgens hem niet zonder meer met God was verbonden. 'Het woordje zelf in zelfbeschikking staat niet tegenover God, alsof het om een keuze zou gaan: of wijzelf beschikken over ons leven óf God, maar het staat tegenover de anderen. (...) de verhouding tussen mens en medemens(en) is het vlak van 
de moraal' (Kuitert 1981: 68). Kuitert vatte zelfbeschikking op als het idee dat er grenzen waren aan de dwang die anderen konden opleggen. Hij pleitte op grond daarvan voor een recht op sterven.

In zijn commentaar op een vonnis van de Hoge Raad liet, Enschedé, oudhoogleraar en oud-raadsheer in de Hoge Raad zien eveneens een voorstander te zijn van het ontplooien van het recht op zelfbeschikking inzake euthanasie. ' $\mathrm{Nu}$ het om een crepeergeval ging kon de Hoge Raad een discussie over niet-crepeergevallen nog uit de weg gaan. Ik denk echter dat we in deze tijd van nog steeds groeiende medische macht, van medische overkill, de weg van het recht tor zelfbeschikking over het eigen leven tot het einde moeten gaan. Ook het nietcrepeergeval van de zeer oude, permanent bedlegerige patiënt die, na jaren van geduld, er eindelijk een eind aan wil zien - ik noem maar wat - kan de hulp van de arts niet ontberen' (Enschede 1985: 244). Het recht op zelfbeschikking achtte hij een geschikte kandidaat in de strijd tegen de toenemende medische macht. Het argument van zelfbeschikking speelde dan ook een belangrijke rol in diverse rechtszaken over euthanasie.

De meningen - ook binnen het strafrecht - verschilden echter over een eventuele wettelijke fundering van zelfbeschikking. Zo liet de jurist Schalken zich, in zijn requisitoir bij een hoger beroep van de rechtbank Alkmaar, sceptisch uit over een beroep op het zelfbeschikkingsrecht. De rechtbank Alkmaar had in een vonnis grote betekenis toegekend aan het zelfbeschikkingsrecht. Voor de rechtbank gold de wil van de patiënt als doorslaggevend. Schalken stelde dat de rechtbank hiermee 'buiten de grenzen van haar bevoegdheden was getreden' (Schalken 1984). Hij benadrukte dat het individuele zelfbeschikkingsrecht noch een expliciet wettelijke, noch een grondwettelijke, noch een verdragsrechtelijke grondslag had. Hij wilde niet dat in deze specifieke zaak een zwaarwegende (juridische) betekenis aan zelfbeschikking werd gegeven. 'De $\mathrm{Rb}$. Alkmaar heeft een juridisch argument - het zelfbeschikkingsrecht - opgevoerd om aan het strafbare feit zijn strafbaarheid te ontnemen; dat dwingt ror een juridische contra-argumentatie. Maar naast de zuiver juridische argumenten zijn er nog andere bezwaren tegen de erkenning van het zelfbeschikkingsrecht inzake de beëindiging van het eigen leven. Zo er al van rechtens een te beschermen belang sprake zou zijn, dan heeft de $\mathrm{Rb}$. door aan het zelfbeschikkingsrecht een hoger gewicht toe te kennen dan aan andere rechtens beschermde en te beschermen belangen, een rechtspolitieke keuze gemaakt die ver uitgaat boven haar eigen typisch rechterlijke bevoegdheid en verantwoordelijkheid' (p. 44). De juristen Schalken en Enschedé kenden in dezelfde zaak dus ongelijke betekenis toe aan de plaats van het recht op zelfbeschikking, inzake sterven en euthanasie. Niet zozeer het morele recht op zelfbeschikking was hier in het geding, maar de al dan niet wettelijke fundering van het zelfbeschikkingsrecht was aan de orde. 
Het effect van de kracht van het paradigma van de autonome of mondige patiënt is dat andersoortig commentaar in de marges bleef hangen. Geluiden die niet binnen de rand van bovenstaande puzzel vielen, werden niet of nauwelijks gehoord. Zo zette de ethicus Klijn vraagtekens bij de rol van zelfbeschikking inzake euthanasie. Volgens hem had het zelfbeschikkingsrecht in het euthanasiedebat een zeer bepaalde betekenis gekregen, $\mathrm{nl}$. het recht om zelf geheel en al over het tijdstip van doodgaan te beschikken. In die zin is het woord zelfs een technische term geworden in de discussie' (Klijn 1985: 60). Hij vond het een verdienste van Leenen dat deze de categorie van de schijngestalten had gecreëerd, maar hij had kritiek op de wijze waarop Leenen en ook Kuitert het concept van zelfbeschikking inzetten in de euthanasiediscussie. Zijn voornaamste kritiek op Leenen kwam neer op diens (formele) invulling van zelfbeschikking: zelfbeschikking als het ultieme kenmerk van mens-zijn. Klijn kon de mens als persoon niet los van anderen zien. ${ }^{13} \mathrm{Hij}$ was een exponent van de sociaallevensbeschouwelijke denkstijl, die niet helemaal van het toneel verdween. Ondanks kritiek op het concept van zelfbeschikking, wordt uit het invulling geven ervan duidelijk dat zelfbeschikking steeds meer als norm beschouwd ging worden. ${ }^{14}$

\section{Zelfbeschikking als norm}

Het begrip zelfbeschikking is een steeds prominentere rol gaan spelen in het gezondheidsrecht en de gezondheidsethiek, alsmede bij beslissingen over het levenseinde. Zelfbeschikking van de patiënt en respect voor autonomie van de patiënt leken een gemeenschappelijk denkkader te vormen voor beide vakgebieden. Dat blijkt uit handboeken gezondheidsrecht en gezondheidsethiek, maar bijvoorbeeld ook uit de voorwaarden die door de verschillende rechtbanken waren opgesteld.

In Voordelen van de twijfel, een inleiding gezondheidserhiek uir begin jaren tachtig was één hoofdstuk gewijd aan basisnormen in de ethiek (Dupuis $\&$ Thung 1983). Genoemd werden: de eerbied voor het leven, Gods geboden, mondigheid en zelfbeschikking. Met name mondigheid en zelfbeschikking kregen ruime aandacht. Met de volgende kanttekening: 'Overigens klinkt het thema van de mondigheid van de mens als moreel uitgangspunt alweer wat ouderwets. In plaats van mondigheid wordt op het ogenblik meer gesproken over de zelfbeschikking van de patiënt, waarmee we zijn aangeland bij een druk besproken thema in de hedendaagse gezondheidszorg' (p. 74). De auteurs kozen er voor om met het begrip zelfbeschikking verder te gaan. Hoewel er volgens hen geen consensus was over zelfbeschikking als 'bescherming van persoon en privacy tegen inbreuken van buitenaf, gingen de auteurs er wel vanuit dat dit juridisch gefundeerd kon worden (met een verwijzing naar het handboek 
geburgerd was, maar niet voor iedereen ook een absolute norm was bij de aanpak van alle medisch-ethische problemen.

Eén van de twee denkstijlen is steeds meer het vanzelfsprekende denkkader geworden. Inzake het levenseinde heeft het zelfbeschikkingsrecht van de patiënt uiteindelijk de zwaarwegende stem gekregen. Het idee van zelfbeschikking werd zowel juridisch als moreel meer uitgewerkt, waardoor het beeld van de patiënt die zelf beschikt gestalte kreeg. Het individueel-humanistisch paradigma is in staat geweest om het onderzoek van zowel recht als ethiek te leiden. Her en der waren nog resten van het sociaal-levensbeschouwelijke paradigma te horen in kritische geluiden (van sommige ethici), maar deze voerden niet de boventoon. De kracht van het paradigma van zelfbeschikking impliceert dat iedereen die tegen de stroom in zwom zich buiten het speelveld plaatste. Kritiek op het concept van zelfbeschikking vond weinig tot geen gehoor. Het succes van zelfbeschikking als uitgangspunt binnen het individueel-humanistisch paradigma kon echter niet vooraf worden bepaald. Met dit succes is euthanasie een probleem van zelfbeschikking geworden, in plaats van een puur medisch probleem of een zingevingskwestie. Dit had tot gevolg dat een brede conceptualisering van euthanasie van tafel was en dat er alleen nog over euthanasie werd gesproken als levensbeëindiging op verzoek van de patiënt. In deze periode van 'normale wetenschap' waren de activiteiten van juristen en ethici gericht op de vergroting van het bereik van de nieuwe inzichten. Het idee van zelfbeschikking werd bijvoorbeeld gebruikt als uitgangspunt bij de aanpak van problemen, zoals in rechtszaken. Maar het werd ook, blijkens verschillende handboeken, de centrale norm binnen de vakgebieden gezondheidsrecht en gezondheidsethiek. In het gebruik van de termen mondigheid, autonomie en zelfbeschikking zijn er meer overeenkomsten dan verschillen te ontdekken tussen recht en ethiek. Het idee van bescherming van de patiënt door middel van respect voor auronomie en het recht op zelfbeschikking is een gedeelde denkstijl.

\section{Een anomalie: de wilsonbekwame patiënt}

\section{Levensbeëindiging bij wilsonbekwamen; een lastig puzzelstukje}

De wilsbekwame patiënt die om levensbeëindiging verzocht - en waarbij aan bepaalde zorgvuldigheidseisen was voldaan - was eind jaren tachtig alom geaccepteerd. ${ }^{16}$ De moeilijkheid lag bij patiënten die niet wilsbekwaam waren of waarbij de wilsbekwaamheid ter discussie stond, maar waar levensbeëinding wel ter sprake kwam. Deze patiënten vormden een probleem binnen het gegeven paradigma van zelfbeschikking. Het door Leenen geïntroduceerde onderscheid tussen zelfbeschikking (over de zin van het leven) van de patiënt en het 
medisch-professionele oordeel (over medisch zinvol en zinloos handelen) van de arts leek niet adequaat genoeg om dit probleem aan te pakken. Er bestond namelijk een categorie patiënten die enerzijds hun wil niet (meer of nog niet) kenbaar kon maken en waarbij anderzijds niet direct sprake was van medisch zinloos handelen. Het was bij deze categorie patiënten echter niet uitgesloten dat er wél sprake was van ondraaglijk en uitzichtloos lijden. Omdat deze patiënten niet konden voldoen aan het beeld van de autonome patiënt, was euthanasie uitgesloten. Het ging om pasgeborenen met moeilijk te behandelen complicaties, comapatiënten, psychiatrische patiënten en demente ouderen. Het is niet zo dat levensbeëindiging zonder verzoek begin jaren tachrig over het hoofd was gezien. Het was veeleer destijds tussen haakjes gezet omdat het een lastig probleem was, een anomalie. Of zoals halverwege de jaren tachtig werd opgemerkt: 'Levensbeëindigend handelen niet op uirdrukkelijk verzoek van de betrokkene (...) wordt naar een (voorlopig) moreel en juridisch niemandsland verwezen' (Keasberry 1985).

De beide genoemde argumenten - de wil van de patiënt en medisch zinloos handelen - vormden een legitimarie om niet door te gaan met behandelen. Op grond van deze argumenten hoefde men geen oordeel uit te spreken over de toestand van de betrokken patiënt (als alternatief voor afgaan op het oordeel door de patiënt). Voor beide argumenten van Leenen gold dat men geen waardeoordeel hoefde uit te spreken. ${ }^{17}$ Het oordeel over de situatie van de patiënt was een terugkerend probleem in de discussie over levensbeëindigend handelen niet op verzoek. Dat is begrijpelijk vanuit een paradigma van respect voor zelfbeschikking (van de patiënt). Als zelfbeschikking het criterium is, dan kunnen beslissingen die niet in het kader van de zelfbeschikking worden genomen problematisch zijn. Dit was dus vooral binnen deze context een probleem. Elk paradigma produceert specifreke anomalieën, maar op voorhand is niet duidelijk welke dat zijn. Deze paragraaf gaat in op de manier waarop wordt omgegaan met het dilemma van levensbeëindigend handelen bij wilsonbekwamen, dat eind jaren tachrig en begin jaren negentig op de agenda kwam. Enerzijds werden er substituten en uitbreidingen geformuleerd voor zelfbeschikking van de patiënt, namelijk of de wil van de patiënt bekend kon worden verondersteld en hoe dan? Door familie of naasten of door naar de waarden van de patiënt zelf te kijken. Anderzijds stond het argument van medisch zinloos handelen als objectief-medisch oordeel ter discussie. Was dit wel een objectief oordeel of betekende dit dat uiteindelijk toch gewoon beslissingsmacht voor de medische professie? Duidelijk is in ieder geval dat de kwestie van de wilsonbekwamen niet goed paste binnen het dan gangbare paradigma, dat voor beide disciplines maatgevend was.

Een anomalie heeft een relevante context nodig om als zodanig erkend te worden. Ook in perioden van normale en min of meer routinematige verhoudingen bestaan er anomalieën, omdat geen enkel paradigma van wetenschap- 
pelijk onderzoek in staat is om alle problemen op te lossen. Als het aantal anomalieën toeneemt en ze niet 'weggewerkt' kunnen worden dan ontstaat, zo is in de tweede paragraaf van dit hoofdstuk beschreven, een crisis. Maar niet elk lastig stukje dat niet binnen het geaccepteerde kader past hoeft onmiddellijk tot een crisis te leiden. Zo werden bijvoorbeeld de duizend gevallen van levensbeëindiging zonder verzoek uit het onderzoek van de Commissie Remmelink ('de duizend van Remmelink'), verdedigd met het argument dat de dood ook zonder handelen van de arts snel zou zijn gekomen (Euthanasie 1991: 15). De grote uitdaging was voor sommigen, met name ethici, om ook het vraagstuk van levensbeëindigend handelen bij wilsonbekwamen in te passen in het dominante denkkader. Een manier om het probleem aan te pakken is dan om het uitgangspunt van het huidige kader te verbreden in plaats van het kader onmiddellijk op de helling te zetten.

Zo stelde de ethicus Jabobs de figuur van de veronderstelde wil voor als substituut voor de wil van de patiënt. Volgens deze filosoof/ethicus kon de 'figuur van de veronderstelde wil' 'haar intrede doen: bij het achterhalen van iemands wensen, bij het bepalen van zijn belangen en bij het respecteren van zijn autonomie' (Jacobs 1987: 88). Dit zou volgens Jacobs met name interessant zijn bij het bepalen van de wil in gevallen waarin ooit van een wil sprake is geweest. Een zaakwaarnemer zou dan uit de eerdere levenswijze van de betrokkene zijn wens kunnen extrapoleren. 'Zoals meer en meer het inzicht doorbreekt dat medisch handelen zinloos en mensonwaardig geworden is, wanneer de patiënt "dank zij" dat handelen alleen wat langer in een uitzichtloze toestand verkeert, zo valt een levensbeëindigende ingreep te verdedigen wanneer zeker is dat de patiënt nooit (meer) tot enig leven in een biografische zin in staat is' (p. I02). Een zaakwaarnemer zou in dar geval volgens Jacobs namens de betrokkene kunnen besluiten dat diens biologische leven beëindigd zou worden. Hij liet hiermee de lijn van respect voor zelfbeschikking niec los, maar zette het argument van de veronderstelde wil ernaast. De zaakwaarnemer werd verondersteld om de reconstrueerbare wil van de betrokkene te kennen.

De ethica Dupuis had een ander voorstel. Hoewel 'ethici en juristen plegen op te merken, dat hier sprake is van een onoplosbaar probleem', was zij het daar niet mee eens (Dupuis 1988c: 1927). Dupuis stelde voor om het idee van nietingrijpen te overwegen als oplossing voor het vraagstuk. De vraag of bij patiënten in coma een behandeling al dan niet ingesteld moest worden was volgens Dupuis een moreel dilemma voor de arts. Enerzijds was hij moreel verplicht te doen wat hij kon voor een comapatiënt, maar anderzijds kon hij daarmee de patiënt ook ernstige schade toe brengen. 'Artsen hebben geen zelfstandige plicht om medisch op te treden. Zowel juridisch als moreel gesproken kan medisch ingrijpen slechts op twee gronden gerechtvaardigd worden: óf er is een wens van de patiënt, óf er is, indien de patiënt geen mening kenbaar kan maken, een 
direct belang van de patiënt bij een behandeling. Is er geen wens van de patiënt en is er ook geen belang van de patiënt, dan is er geen plicht om te handelen voor artsen' (Dupuis 1988b). Met andere woorden, als het belang van de patiënt ontbrak, dan ontbrak tevens een rechtvaardiging voor de arts om te behandelen. Enerzijds werd met deze redenering het uitgangspunt van zelfbeschikking niet losgelaten: het argument van niet-ingrijpen was slechts een goede aanvulling op dit uitgangspunt. Door er namelijk van uit te gaan dat comapatiënten geen directe wens noch een direct belang hadden bij behandeling, verviel volgens haar de plicht tot behandelen. Anderzijds sloot deze redenering aan bij het argument van medisch zinloos handelen: als er geen wil of een belang van de patiënt is, is medisch ingrijpen niet gelegitimeerd.

Het concept van medisch zinloos handelen, dat in eerste instantie als een medisch-objectief oordeel was beschouwd werd gaandeweg toch ook voor meerdere uitleg vatbaar. Volgens enkele rapporten over levensbeëindiging bij wilsonbekwamen van de KNMG was juist het medisch objectiveren van het medisch zinloos handelen een probleem. ${ }^{18}$ In deze serie van vier rapporten werden de verschillende categorieën patiënten waar het hier om ging besproken. Het bleek dat men terugkwam van het idee dat medisch zinloos handelen medisch objectief zou zijn. In het rapport over levensbeëindigend handelen bij ernstig demente patiënten stond bijvoorbeeld dat het oordeel over wat medisch zinloos was in dergelijke situaties mede kon worden bepaald aan de hand van de veronderstelde wil van de patiënt én op basis van wat behandelaars en naasten in het belang van de patiënt achtren (KNMG 1993). De vraag wat medisch zinloos handelen was, werd dus niet alleen op basis van een medisch-professioneel of medisch-objectief oordeel beantwoord. Ook hier werd het argument van 'in het belang van' naast de wil van de patiënt gehanteerd. Voor de pasgeborenen werd gesteld dat ouders namens het kind geen verzoek konden doen, maar zij werden wel betrokken in het besluitvormingsproces. Het alternatief, het staken of niet aanvangen van een medisch zinloze behandeling, werd eveneens niet als een oplossing gezien. 'Binnen de beroepsgroep bestaan daarover verschillende opvattingen. Dit maakt de term medisch zinloos moeilijk hanteerbaar in absolute zin' (KNMG 1993). De aanvankelijk objectieve status van het oordeel over medisch zinloos handelen werd steeds meer in twijfel getrokken. Dat betekent dat dat idee ontstond dat waardeoordelen (onvermijdelijk) een rol speelden bij medische beslissingen rond het levenseinde.

De ethicus Musschenga bijvoorbeeld liet het idee van zelfbeschikking niet los, maar voegde daar het argument van kwaliteit van leven aan toe. De grenzen van het denkkader werden verder in de breedte verkend. Hieronder viel de verdediging van het 'kwaliteit van leven' argument, wellicht als reactie op de (juridische) scheiding tussen feiten en waarden. Zo was Musschenga van mening dat waardeoordelen over individuele menselijke levens onvermijdelijk waren 
bij keuzes tussen levensverlenging en levensbeëindiging. Hij was het niet eens met de stelling van Leenen dat kwaliteit van leven argumenten geen oplossing boden voor het probleem van het al dan niet instellen of continueren van medische behandelingen. ${ }^{19}$ Musschenga wilde niet het argument 'in het belang van' inzetten bij het beantwoorden van de vraag of het leven van comateuze patiënten instandgehouden of beëindigd moest worden, maar hij stelde wel: 'Uiteindelijk moeten waardeoordelen over menselijk leven de doorslag geven' (Musschenga 1987: 132). Een behandeling zou zinloos zijn als ze voor de betrokkene geen waarde meer had. Een oordeel over medisch zinloos handelen was voor hem dan ook gefundeerd op een waardeoordeel over het menselijk leven. In dic zin achtte hij 'het nalaten of staken van levensverlengende behandelingen bij zwaar demente pariënten, comateuze patiënten en pasgeborenen van wie verwacht wordt dat zij zwaar geestelijk gehandicapt zullen zijn, moreel gerechtvaardigd' (p. 137). Het kwalititeit van leven argument zou hier, als waardeoordeel, een legitimering voor vormen.

Niet iedereen was overtuigd van de functie van waardeoordelen in de discussie over levensbeëindigend handelen. De rapporten van de KNMG, en ook van de Nederlandse Vereniging voor Kindergeneeskunde, hebben bijvoorbeeld bij enkele juristen kritische reacties opgeleverd. De jurist Hubben meende dat genoemde rapporten een gevaar vormden voor de positie van de wilsonbekwame patiënt in de gezondheidszorg. Het gevaar zat volgens hem in het loslaten van medisch zinloos handelen als een objectief medische norm en in het loslaten van de eis dat er sprake moest zijn van een uitdrukkelijk verzoek. Hierdoor zouden juridische grenzen worden verlegd. 'Ontstaat zo niet veel ruimte voor de interpretatie van de wil van de patiënt en daarmee voor druk van buitenaf om ror levensheïindiging bij demente bejaarden over te gaan?' (Hubben 1993: 208). Een\%:lfde bezorgdheid uittc Hubben over her gebruik van (toekomstige) kwaliteit van liven argumenten. Zijn collega Gevers nam eveneens een kritisch standpunt in, maar was minder stellig in zijn afwijzing van bepaalde argumenten. ${ }^{20}$ $\mathrm{Hij}$ erkende dat waardeoordelen bij de bepaling van medisch zinloos handelen 'niet geheel te vermijden' waren en vond het ook begrijpelijk dat men als oplossing voor de problematiek zoveel mogelijk de kenbare wil van de onbekwame patiënt als richtsnoer gebruikte. Maar hij waarschuwde: 'Men zal hoe dan ook eerst meer moeten weten over de mogelijkheden om de wil van de onbekwame pariënt op een zo betrouwbaar mogelijke manier te kennen, voordat aan de praktijk het advies gegeven wordt in voorkomende gevallen de wil van de patiënt maar te "reconstrueren"' (Gevers 1993: 470). Hij vreesde dan ook op grond van bovengenoemde rapporten voor een glijdende schaal tussen levensbeëindiging op verzoek en levensbeëindiging zonder verzoek.

De ethicus Den Hartogh kwam met een oplossing die enigszins in de lijn van Jacobs' veronderstelde wil lag, maar wel een andere invulling van het idee 
van zelfbeschikking behelsde. Den Hartogh deelde het standpunt dat waardeoordelen onontkoombaar waren in beslissingen over her staken van een behandeling bij coma-patiënten en hij was van mening dat argumenten als medisch zinloos handelen en menswaardigheid nier houdbaar waren. 'De zwakte van deze argumenten ligt daarin, dat zij het subjectieve perspectief van waaruit waardeoordelen moeten worden geveld over het leven van de patiënt identificeren met het perspectief van de huidige patiënt, die nu eenmaal geen perspectief meer heeft' (Den Hartogh 1995: 1226). Hij stelde dat er bij de beslissing om een behandeling te staken toch een persoonlijk belang was, namelijk het belang om behandeld te worden in overeenstemming met de waarden die het leven van de betrokken patiënt hadden bepaald. Het ging dan niet om een waardeoordeel over de huidige toestand van de patiënt, maar om het gezichtspunt van de patiënt zoals hij was, dus in zijn leven vóór de vegetatieve toestand. De vraag zou moeten luiden of de huidige vegetatieve toestand als een geïntegreerd onderdeel van de biografie van de patiënt kon worden beschouwd of niet. Het standpunt van Den Hartogh was een kritiek op de manier waarop met waardeoordelen werd omgegaan in officiële rapporten over dit dilemma. ${ }^{21}$ Daarin ging men alleen uit van waardeoordelen over de huidige toestand van de patiënt. Den Hartogh meende dus de oplossing van het vraagstuk te vinden in de wil van de patiënt gekoppeld aan diens biografie.

Gaandeweg de discussie werd het vraagstuk van levensbeëindiging zonder verzoek erkend als een lastig probleem. In eerste instantie waren de oplossingen die ervoor werden aangedragen nog nauw verwant aan het uitgangspunt van zelfbeschikking van de patiënt, maar in een later stadium werden waardeoordelen van derden minder taboe. Redeneren 'in het belang van de patiënt' als uiting van barmhartigheid of weldoen was steeds vaker te vinden in de aangedragen argumenten. Formeel mocht er dan geen verzoek tor levensbeëindiging liggen, door sommigen werd aangenomen dat dit verzoek via allerlei omwegen wél 'geconstrueerd' kon worden. In deze constructies werd de wil van de patiënt opge-rekt door formuleringen als 'de veronderstelde wil' en 'de wil van de patiënt gekoppeld aan diens biografie’. Deze construcries waren dus substituten voor het verzoek van de patiënr, maar bleken geen werkelijke alternatieven.

\section{Alternaticve argumenten en denkstijlen}

De vraag hoe de discussie over de wilsonbekwamen gevoerd moest worden - welke oordelen wel en welke niet gelegitimeerd waren - was één aspect van de discussie. Parallel aan deze discussie werd ook naar 'goede' alternatieven gezocht voor het principe van respect voor autonomie en de wil van de patiënt. Dit waren argumenten die niet meer alleen een substituut voor de wens van de patiënt, maar ook een alternatief daarvoor waren. De verkenning van deze alter- 
natieven als denkstijl lag vooral in handen van ethici, soms gevoed door maatschappelijke ontwikkelingen. Het in gebreke blijven van bestaande regels was het voorspel tot de zoektocht naar nieuwe. Er ontwikkelden zich nieuwe denkstijlen, die verschilden van het uitgangspunt van respect voor autonomie of zelfs expliciet kritiek hadden op het uitgangspunt van zelfbeschikking (zowel bij levensbeëindiging op als zonder verzoek).

De ethicus Kuitert liet het idee van zelfbeschikking los in zijn beschouwing over levensbeëindiging niet op verzoek. Hij beriep zich niet op de argumenten van 'in het belang van' of 'kwaliteit van leven', maar op het argument van het medisch-professionele oordeel van de arts en van barmhartigheid (in geval van 'noodgevallen'). Als een patiënt geen verzoek meer kon indienen betekende dat volgens Kuitert niet dat een arts zijn medische verantwoordelijkheid zou verliezen de arts nam integendeel 'het initiatief van de patiënt over en bepaalt zelf, varend op het kompas van zijn professie, of het uur van het bittere einde gekomen is en als hij daarvan overtuigd is, helpt hij de patiënt eruit, ook zonder dat deze erom vraagt' (Kuitert 1993: 86). Het medisch professionele oordeel van de arts (zonder dat dit de pretentie van medisch objectief heeft) kon kennelijk in noodgevallen de leidraad van het medisch handelen zijn in plaats van de wil van de patiënt. Kuitert haalde nog een tweede argument aan. 'We moeten kiezen, soms/niet altijd, tussen vasthouden aan het principe "nooit levens zonder verzoek daartoe beëindigen", wat meebrengt: onbarmhartigheid, en het in noodgevallen loslaten van dat principe, dus een leven beëindigen zonder dat er een vraag was, en daarmee de barmhartigheid redden' (p. 85). Het argument van barmhartigheid, dat in de discussie over levensbeëindiging op verzoek geen noemenswaardige rol speelde, bleek nu wel een aanknopingspunt in de discussie te zijn. Barmhartigheid was geen nieuw argument, maar het gegeven dat het niet of nauwelijks werd gebruikt in de discussie over levensbeëindiging op verzoek zegt veel over de kracht van het gedeelde denkkader in de jaren tachtig. Kuitert zag in het argument van barmhartigheid zelfs een mogelijkheid om tot consensus te komen tussen ethici en juristen. ${ }^{22} \mathrm{Bij}$ dit argument van barmhartigheid moet de kantrekening worden gemaakt, dat het niet direct terug te vertalen is naar de paternalistische houding van de arts uit de jaren zestig. De nieuwe waarden met betrekking tot de positie van de patiënt konden niet met één pennenstreek aan de kant worden gezet.

Kuitert had nog een derde benadering voor het probleem van de wilsonbekwamen, in dit geval de pasgeborenen. Hij introduceerde de term 'onleefbaar leven', als inschatting van de toekomstige kwaliteit van leven van een zwaar gehandicapte pasgeborene. De term 'onleefbaar leven' toonde verwantschap met het begrip 'kwaliteit van leven', met die kanttekening dat het waardeoordeel nog duidelijker aanwezig was. Een definitie van onleefbaar leven kon volgens Kuitert niet met zekerheid worden gegeven, het zou uiteindelijk om voorbeelden moe- 
ten gaan. Hij koppelde daaraan het idee van een ondergrens of een 'bodem' van het menselijk bestaan. 'Menszijn heeft een bodem, een ondergrens: wie daar beneden komt, is nog steeds een mens net als wij, met dezelfde rechten als wij, ook het onvervreemdbaar recht op leven. Alleen - het heeft geen zin meer om dat recht te realiseren, want het kindje is door de bodem gezakt van wat wij nog een aanvaardbare manier van menszijn kunnen noemen. De dokter wil wel redden wat er te redden valt, maar er valt niets meer te redden' (Kuitert 1993: 113). Kuitert had hiermee drie alternatieve benaderingen gegeven voor het dilemma van levensbeëindigend handelen zonder verzoek; het medisch-professionele oordeel, barmhartigheid en het argument van onleefbaar leven. Alle drie de argumenten waren niet gerelateerd aan het uitgangspunt van zelfbeschikking.

Het feit dat een exclusief beroep op het beginsel van zelfbeschikking weinig aanhangers had bij het dilemma van de wilsonbekwamen was niet de enige reden dat zelfbeschikking ter discussie stond of werd losgelaten. Er was ook fundamentele kritiek op het concept zelf. In eerste instantie gebeurde dat zonder dat er concrete alternatieven voor handen waren (Ten Have \& Kimsma 1987: 81). In de jaren negentig was de kritiek steviger en meer fundamenteel van aard. Zo bekritiseerde de ethicus Zwart het zelfbeschikkingsdenken in de gezondheidsethiek en in discussies over euthanasie in het bijzonder. Hij vatte het zelfbeschikkingsdenken op als resultaat van een (dominante) ethiek als belangenafweging. Deze manier van ethiek bedrijven schoot volgens hem tekort, zeker in discussies over levensbeëindigend handelen. Hij haalde het genoemde boek van Kuitert aan als voorbeeld voor het verkeerd op de agenda zetten van zelfbeschikking en levensbeëindigend handelen. Zelfbeschikkingsdenken en belangenethiek deden volgens Zwart onvoldoende recht aan de 'basale ervaring van aarzeling en reserve die wij tegenover levensbeëindiging aan de dag leggen' (Zwart 1995: 56). Hij stelde zich ten doel om deze (morele) ervaringsaspecten op de ethische agenda te zetten. Deze morele ervaring en aarzeling zouden bijvoorbeeld bij de problemariek rond levensbeëindiging en wilsonbekwamen zeggenschap hebben. 'Het vertrekpunt voor een ethische beschouwing over hulp bij zelfdoding in de psychiatrie moet worden gezocht in de fundamentele en hardnekkige ervaring van aarzeling en reserve die zich aan hulpverleners opdringt wanneer zij in de prakrijk met een verzoek om hulp bij zelfdoding worden geconfronteerd. De benadering van de morele casuïstiek in termen van weldoen en autonomie, laat restervaringen onbegrepen en onbesproken, die om nadere benoeming en precisering vragen' (p. 66). Zwart benaderde het probleem van levensbeëindiging bij wilsonbekwamen vanuit een geheel nieuw perspectief. Het uitgangspunt van de zelfbeschikking werd losgelaten en daarvoor in de plaats was het perspectief van de morele ervaring gesteld: wat is de betekenis van de ervaring van 'reserve' als het gaat om levensbeëindiging bij wilsonbekwamen? Dit betekende een herdefiniëring van het probleem van levensbeëin- 
digend handelen, omdat zelfbeschikking van de patiënt niet zonder meer het enige mensbeeld was. De kritiek op de inzet van zelfbeschikking was serieus, maar het is nog de vraag of het alternatief van de morele ervaring vruchtbaar zal zijn en voldoende aanhangers kan vinden.

Ook in het gezondheidsrecht was er kritiek op zelfbeschikking als één van de pijlers van het gezondheidsrecht. ${ }^{23}$ Deze kritiek was echter gebaseerd op her idee dat er helemaal geen geldende beginselen en grondslagen zouden kunnen zijn voor de discipline gezondheidsrecht (Sluyters 1985). Net als Zwart knaagde Sluytcrs aan het fundament van zijn discipline. Hij trok de homogeniteit van het vakgebied in twijfel, door te stellen dat her gezondheidsrecht een 'conglomeraat van rechtsregels' was. Dit gebeurde echter niet in de context van de discussie over levensbeëindigend handelen (met of zonder verzoek). Fundamentele kritiek op gezondheidsrechtelijke uitgangspunten in de discussie over levensbeëindiging op of zonder verzoek leek er niet te zijn. Kortom, het denken in termen van zelfbeschikking leek niet onfeilbaar te zijn, maar was wel een belangrijk uitgangspunt voor beide vakgebieden in de discussie over levensbeëindiging. Met name uit pogingen om een oplossing te vinden voor de problematiek van levensbeëindiging bij wilsonbekwamen was duidelijk dat het paradigma van respect voor zelfbeschikking een grote rol speelde. Enerzijds als uitgangspunt en anderzijds als kader waarin men als het ware gevangen zat en naarstig naar daadwerkelijke alternatieven zocht.

De wilsonbekwame patiënt werd een lastig puzzelstukje of anomalie bij vragen rond het levenseinde. Dit zette het denken in termen van respect voor autonomie of zelfbeschikkingsrecht van de patiënt op scherp. Maar dat gold voor ethici en juristen niet op dezelfde manier. Juristen zagen het probleem van de levensbeëindiging bij wilsonbekwamen als een apart probleem van her debat over euthanasie, terwijl ethici het juist in het debat wilden integreren. Vanuit juridische hoek werd alleen het argument van medisch zinloos en medisch zinvol handelen gepropageerd en wel als een objecrief medisch-professioneel oordeel. Als er sprake was van medisch zinloos handelen, diende dit gestaakt te worden. Hiervoor was geen oordeel van de patiënt nodig. Alternatieven uit ethische hoek waren het argument van kwaliteit van leven, de veronderstelde wil van de patiënt en het belang van de patiënt zelf. Deze betekenden alle een nieuwe positie van de - wilsonbekwame - patiënt bij levensbeëindigend handelen. Het 'oordeel door' de wilsbekwame patiënt werd haast onvermijdelijk een 'oordeel over' de wilsonbekwame patiënt. Hierdoor kwam het idee van autonomie of zelfbeschikking in het gedrang. Bij ethici ging de discussie over welke argumenten wel en niet valide zouden zijn bij de aanpak van dit probleem. De wilsonbekwame patiënt als lastig puzzelstukje heeft bij ethici tot openingen voor een nieuwe denkstijl geleid. Een denkstijl waarin ruimte was voor waardeoordelen, terwijl in het gemeenschappelijke denkkader alleen objectieve oor- 
delen en de patiëntenwil als argument golden. Juristen hielden vast aan dit laatste denkkader. De verschillen tussen beide liepen niet zo ver uiteen dat er eind jaren negentig sprake was van een crisis in het medisch-ethisch denken. Er tekenden zich echter wel verschillen af in het voorheen voornamelijk homogene denken. Of zich te zijner tijd opnieuw een crisis zal voordoen, hangt af van nieuwe ontwikkelingen en een mogelijke opeenstapeling van anomalieën.

\section{Medisch-ethisch denken in het licht van wisselende denkstijlen}

Hoe ziet de conceptuele ontwikkeling in het denken over levensbeëindigend handelen binnen gezondheidsethiek en gezondheidsrecht eruit? Beide vakgebieden zijn tot ontwikkeling gekomen in een fase waarin het oude paradigma van medische ethiek als een set van beroepscodes in twijfel werd getrokken. In dit oude paradigma, dat tot ver in de jaren zestig gangbaar is geweest, had de patiënt een passieve rol met betrekking tot beslissingen over ziekte en gezondheid. Als gevolg van de ontwikkelingen in de medische wetenschap veranderde de positie van de patiënt. Er ontstond een 'nieuwe' categorie patiënten - de te ver doorbehandelde patiënten, waarvan eerder het sterfbed dan het leven wordt verlengd - waarvoor het oude paradigma geen goede oplossing te bieden heeft. In deze periode van crisis in de medische ethiek verloor het oude paradigma zijn bindende kracht. Her beeld van medische ethiek als beroepscodes verdween naar de achtergrond en maatschappelijke idealen konden het debat meer beinvloeden, met als gevolg de ontwikkeling van nieuwe denkstijlen.

De analyse van het debat over levensbeëindigend handelen levert aanknopingspunten op om aan denkstijlen en paradigmata een verschillende functie toe te kennen. Tijdens een periode van normale wetenschap is er geen behoefte aan voeding vanuit de maatschappij; men kan de aanpak van onderzoek binnen het paradigma af. Tijdens een periode van crisis of revolutie daarentegen is er ruimte voor invloeden van ideeën en idealen vanuit de maatschappij. Juist in die fase zijn denkstijlen van betekenis, omdat zij niet gebonden zijn aan een discipline. In tegenstelling tot een paradigma dat wél cognitief verbonden is met één of meerdere vakgebieden, staan denkstijlen open voor invloed vanuit de maatschappij. Het begrip denkstijlen biedt houvast om het werk van onderzoekers ten aanzien van begripsontwikkeling tijdens een periode van crisis te beschrijven, terwijl het begrip paradigma geschikt is om veranderingen in de ontwikkeling van wetenschappelijke gemeenschappen te beschrijven. Denkstijlen en paradigmata vervullen dus afwisselend de rol van richting geven aan het (wetenschappelijke) denken.

Het nieuwe paradigma voerde vanaf de jaren zeventig de boventoon in het denken over medische ethiek. In dit paradigma leidde het beeld van de auto- 
nome pariënt het medisch-ethisch denken. Dit betekent dat alleen op verzoek van de patiënt, indien aan bepaalde zorgvuldigheidseisen was voldaan, van euthanasie kon worden gesproken. Respect voor autonomie of zelfbeschikking werd voor zowel ethici als juristen de leidraad voor het denken en het wetenschappelijk onderzoek. Het vormde de basis voor een nieuw paradigma. Vanuit dat perspectief moeten dan ook observaties van eind jaren tachtig over het (te) dicht naar elkaar toegegroeid zijn van recht en ethiek worden geplaatst. ${ }^{24} \mathrm{Het}$ idee van een duidelijke scheiding russen beide vakgebieden is meer een ideaal dan empirisch gegeven.

Het gedeelde paradigma als gemeenschappelijke denkkader voor beide vakgebieden is een consequentie van het feit dat beider wortels in de crisis in de medische ethiek van de jaren zestig liggen. Hierdoor hebben beide vakgebieden, hoewel voortgekomen uit verschillende moederdisciplines, een gemeenschappelijk paradigma aangenomen. Dit hoofdstuk laat zien dat in tegenstelling tot wat er uit kritiek op de verhouding tussen recht en ethiek valt af te leiden, namelijk dat ethiek en recht twee gescheiden vakgebieden met een verschillend denkkader zouden (moeten) zijn, er lange tijd geen sprake was van twee verschillende paradigmata. ${ }^{25}$ Tot eind jaren tachtig was er, hoewel er ook verschillen te onderkennen zijn, een gemeenschappelijke paradigma voor de ethiek en het recht. Respect voor autonomie of zelfbeschikking van de patiënt is één van de vier principes in de ethische theorie voor het medisch handelen geworden (naast weldoen, niet-schaden en rechtvaardigheid). In de literatuur speelde het principe van respect voor autonomie als argument aanvankelijk een belangrijker rol dan de andere drie principes. Later kwamen er in de discussie wél argumenten als niet-schaden en weldoen (of barmhartigheid). Deze begrippen waren dan ook niet nieuw voor ethici, maar de centrale rol voor het argument van respect voor autonomie geeft aan dat het gedeelde denkkader zeer overtuigend en krachrig was, zeker in de jaren tachtig.

Het denken in termen van 'respect voor autonomie of zelfbeschikking' was weliswaar breed gedeeld, maar niet vrij van problemen. De problematiek rond levensbeëindigend handelen en wilsonbekwamen was bijvoorbeeld een lastig puzzelstukje dat een inspiratiebron vormde voor nieuwe discussies en argumenten. Begin jaren negentig werden, met name door ethici, alternatieven en substituten bedacht voor de wil of de wens van de patiënt. Sommigen bleven daarbij dichter bij het principe van respect voor autonomie dan anderen. Dit zoeken laat zien dat er ruimte voor een ander perspectief ontstond. Hierdoor kwamen er ook verschillen tussen sommige ethici enerzijds en juristen anderzijds naar voren, zonder dat er van een crisis sprake was in de zin van direct een concreet, alternatief paradigma. Het gemeenschappelijke paradigma vertoonde echter wel enkele barsten. Door sommige ethici werd de dominantie van her concept van autonomie of zelfbeschikking in de gangbare medische ethiek ter discussie 
gesteld.$^{26}$ In eerste instantie waren dat kritische geluiden over het algemene gebruik van zelfteschikking bij medisch-ethische kwesties, zonder dat er werkelijk alternatieven werden gegeven. Later was de aanval meer frontaal op het moment dat het denken in termen van zelfbeschikking als onderdeel van de gangbare ethiek werd bekritiseerd, omdat de ethiek zelf - als een ethiek van belangenafweging - ter discussie stond.

Met name ethici onderling gingen begin jaren negentig de strijd met elkaar aan over - in breder verband - de rol en functie van de gezondheidsethiek als toegepaste ethiek, zoals beschreven in hoofdstuk twee. Hermeneutische ethiek zette zich af tegen zogenoemde regelethiek; de brede moraal (morele kwesties in hun context plaatsten) tegen de smalle moraal (principe-ethiek). Later kwam er een derde stroming bij, de zorgethiek. Daarin werd kritiek geleverd op de nadruk op rechten in de ethiek; het morele karakter van zorgrelaties zou door het rechtendiscours worden vertekend. ${ }^{27}$ Deze bewegingen geven aan dat er aan het dominante denkkader werd getornd. In hoeverre deze ontwikkelingen tot een nieuw paradigma in de medische ethiek, voor gezondheidsethiek en/of gezondheidsrecht, kunnen leiden is halverwege de jaren negentig nog maar de vraag. Daarop is ook nu geen eensluidend antwoord te geven. De sociaal-conceptuele analyse in dit hoofdstuk levert geen overtuigend bewijs op voor de veronderstelling dat er sprake zou zijn van een verschillend vocabulaire voor de disciplines recht en ethiek. De begrippen auronomie en zelfbeschikking worden door elkaar gebruikt. Genoemde veronderstelling is dan ook meer, in lijn met het vorige hoofdstuk, als een recente jurisdictieclaim dan als een afgebakende inzet van beide vakgebieden te beschouwen. Deze claim is (wellicht) ingegeven door het normatieve idee dat ethiek en recht gescheiden vakgebieden, met ook een apart vocabulaire, zouden moéten zijn. Het euthanasiedebat, in de jaren tachtig en begin jaren negentig, bevestigt deze opvatting echter niet. 



\section{NORMERING EN REGULERING VAN LEVENSBEËINDIGEND HANDELEN}

'Artsen, ethici en juristen zouden mijns inziens in onderling overleg kunnen komen tot het uitzetten van een kader van voorwaarden die, indien zij tegelijk zijn vervuld, voor de rechter een buitemwettelijke rechtvaardiging kunnen vormen voor de in aansluiting daarop tevens exact gedefinieerde euthanasie. Daarbij zal een rechter ongetwijfeld kunnen eisen dat bewijshadr is, dat het betreffende geval aan de in de definitie gegeven omschrijving voldoet.'

(Van Till x973)

In bovenstaande uitspraak vraagt de juriste Van Till om een kader van voorwaarden, dat nier alleen een juridische invulling zou moeten krijgen: die nieuwe regels zouden volgens haar 'in onderling overleg', tot stand kunnen komen. Zoals uit de vorige twee empirische hoofdstukken naar voren is gekomen vormen de vragen rond het levenseinde in de jaren zestig en zeventig een nieuw probleem waarvoor geen (standaard) aanpak voorhanden is. Er zullen nieuwe opvattingen en inzichten ontwikkeld moeten worden. We weten nu dat bij de wijze waarop euthanasie in Nederland gereguleerd is, de zogenoemde zorgvuldigheidseisen voor euthanasie centraal staan.' Deze zorgvuldigheidseisen zijn de voorwaarden die concreet handen en voeten geven aan termen als zorgvuldig medisch handelen en medisch verantwoord handelen. Ze tasten niet de strafbaarheid van euthanasie aan, maar geven een omschrijving van situaties waarin het toepassen van euthanasie 'gedoogd' kan worden.

Door de zorgvuldigheidseisen moet duidelijk blijken dat het toepassen van euchanasie op goede gronden gebeurt en goed wordt uitgevoerd. Deze eisen vormen her gezicht van een controleerbare euthanasiepraktijk. In deze aanpak van de dilemma's rond euthanasie zijn verschillende aspecten van levensbeëindigend handelen (het op verzoek, het lijden en de procedure) met elkaar verbonden. Moraliteit, professionaliteit en legitimiteit worden tegelijkertijd en in samenhang met elkaar ontwikkeld. De zorgvuldigheidseisen kunnen worden beschouwd als het voorlopig resultaat van een zoektocht naar (nieuwe) normen en regels voor levensbeëindigend handelen in een medische context. De eisen van zorgvuldigheid zijn in de voorgaande hoofdstukken inhoudelijk en passant al aan de orde geweest. In dit hoofdstuk worden ze aan een nadere analyse onderworpen, omdat ze een belangrijk onderdeel zijn van de normering en 
regulering van de euthanasiepraktijk en thans een zelfstandige functie hebben in deze praktijk. Kort gezegd wordt in dit hoofdstuk de 'zwarte doos' van de zorgvuldigheidseisen geopend, om te zien wat voor werk en moeite het heeft gekost om tot deze eisen te komen en ze te laten funcrioneren. ${ }^{2}$ Dit moet inzicht geven in de manier waarop een rijtje van vijf min of meer praktische criteria is uitgegroeid tot een cruciaal concept in de Nederlandse praktijk van levensbeeindigend handelen. ${ }^{3}$ De zorgvuldigheidseisen vormen al twee decennia het brandpunt van de toetsingspraktijk voor levensbeëindigend handelen. Sinds 1998 worden gemelde gevallen van euthanasie en hulp bij zelfdoding door de regionale toetsingscommissies getoetst, aan de hand van de normen en regels zonls weergegeven in de zorgvuldigheidseisen.

In beschrijvingen van de totstandkoming van de zorgvuldigheidseisen ligt de nadruk veelal op wie welke bijdrage heeft geleverd aan de ontwikkeling of uirkristallisering van de eisen. Meestal worden dan rechtspraak, rechtbanken, artsen, de regering en diverse verenigingen genoemd (Legemaate 1998a; Weyers 200I). Wat in deze beschrijvingen opvalt is dat de dynamiek in de ontwikkeling van de zorgvuldigheidseisen ontbreekt. De interactie tussen de verschillende actoren lijkt, min of meer vanzelfsprekend en automatisch, tot het resultaat van de zorgvuldigheidseisen te hebben geleid, alsof deze specifieke mix van ingrediënten slechts tot dat ene product had kunnen leiden. Daar is echter wel de nodige arbeid mee gepaard gegaan. Dit hoofdstuk beoogt inzicht te geven in de dynamiek van het tot stand komen van de zorgvuldigheidseisen en het werk dat hiervoor is verricht. Hoé heeft een rijtje voorwaarden voor het roepassen van euthanasie kunnen uitgroeien tot een sleutelconcept voor de normering en regulcring van de medische praktijk van levensbeëindigend handelen? En welke andere opties waren er?

Bij de beschrijving van het tot stand komen van normering en regulering vour cuthanasie, staat de verhouding tussen recht en erhiek centraal. Normering wordt in dit hoofdstuk opgevar als het vaststellen van normen, regulering als het bepalen van een regeling en regelgeving als het wettelijk vastleggen van regels. In een model over de verhouding tussen recht en ethiek, dat representatief zou zijn voor een democratische rechtsstaat, zijn rechtsnormen veelal gebaseerd op erhische principes die de publieke moraal betreffen (Maneschijn 1993: 28 e.v.). Dat wil zeggen dat rechtsnormen niet zomaar tot stand komen, maar gerelateerd zijn aan morele consensus binnen een democratie. Het recht baseert zich aldus op vanuit de ethiek geformuleerde normen. Binnen de ethiek vindt een normatieve verkenning plaats. Het recht volgt, om aan te geven hoe de juridische inkadering eruit zou kunnen zien. In de literatuur zijn echter ook andere opvattingen over de taken vari ethici en juristen en normering en regulering te vinden. Bijvoorbeeld gezondheidsethiek als een vorm van morele besliskunde. In dat geval zouden ethici een probleemoplossende zouden hebben (Van Willigenburg 1993). 
Of het recht als 'reserve normering', dan is 'het recht vergelijkbaar met een winterdijk, waar de rivier ruimschoots tussendoor stroomt maar op het moment dat er iets helemaal misgaat, niet overheen kan' (Trappenburg 1993: 232). In dit hoofdstuk is de rol van recht en ethiek bij de normering en regulering van levensbeëindigend handelen een open vraag. Er wordt niet zonder meer vanuit gegaan dat er een vaste verhouding is tussen ethiek en recht, bijvoorbeeld eerst normatieve ontwikkelingen en vervolgens pas regulering. Ethiek en recht worden symmetrisch behandeld om te onderzoeken hoe ze zich tot elkaar verhouden.

Om te onderzoeken hoe normering en regulering rond levensbeëindigend handelen tot stand zijn gekomen en wat dit betekent, wordt in dit hoofdstuk gebruik gemaakt van inzichten uit het wetenschapsonderzoek (Hagendijk 1996). Het wetenschapsonderzoek leent zich goed voor onderzoek naar de manier waarop nieuwe inzichten, in dit geval met betrekking tot normering en regulering van levensbeëindigend handelen in de medische praktijk, in onze samenleving tot stand komen en zich vestigen. Het biedt inzicht in de hoeveelheid werk die vereist is om tot een succesvol resultaat te komen. Het uitgangspunt is dat nieuwe inzichten en de uiteindelijk tot stand gekomen normering en regulering zich ontwikkelen door het bouwen van netwerken. Binnen die netwerken vervult overleg wel een bepaalde functie, maar dit hoeft niet altijd tot consensus te leiden. De hardheid van een netwerk hoeft namelijk niet te berusten op expliciete overeenstemming. Regelgeving voor euthanasie, het de facto in wetten vastleggen van normen en regels, is het resultaat van de manier waarop het netwerk van medische beslissingen rond het levenseinde is opgebouwd. Dat betekent dat de betreffende normen en regels uiteindelijk als 'gegeven' door het leven gaan. Sommige normen en regels zijn net als sommige feiten 'harder', omdat ze ingebed zijn in een netwerk van relaties met andere normen, regels en kennis (wetgeving, protocollen, richtlijnen, voorschriften).

In dit hoofdstuk wordt beoogd inzicht te krijgen in de wijze waarop normering en regulering van levensbeëindigend handelen tot stand zijn gekomen en hoe recht en ethiek daarbij een rol hebben gespeeld en ontwikkeld zijn. Het hoofdstuk is als volgt opgebouwd. $\mathrm{Na}$ een uiteenzetting van het theoretisch kader dat in dit hoofdstuk is gehanteerd gaat de derde paragraaf in op de manier waarop het netwerk rond euthanasie van de grond is gekomen, c.q. de manier waarop een bepaalde normatieve en regulatieve orde is uitgekristalliseerd. De volgende paragraaf handelt over de manier waarop aan dit netwerk verder werd gebouwd. Welke voorstellen zijn er gedaan om de vraag of euthanasie door artsen straffeloos kon worden toegepast te beantwoorden? In de vijfde paragraaf staan nieuwe koppelingen in het netwerk centraal en met name de betekenis hiervan voor de gecreëerde normering en regulering. In de laatste paragraaf volgt de conclusie van het hoofdstuk waarin de betekenis van de netwerkanalyse voor het tot stand komen van normering en regulering wordt weergegeven. 


\section{Theoretisch kader}

Binnen het wetenschapsonderzoek is het ordeningswerk van wetenschappers en professionals beschreven als een proces van netwerkbouw (Latour 1988). Wetenschappers zijn goede retorici die er continu op uit zijn om hun beweringen sterker en geloofwaardiger dan die van anderen te maken. Ze publiceren wetenschappelijke artikelen om hun argumenten de wereld in te sturen. Sommige van deze teksten raken - achteraf gezien soms onbedoeld - met elkaar verbonden en zijn daarmee in staat om allerlei versterkingen te mobiliseren. De lezer wordt als het ware onvermijdelijk in een bepaalde richting gestuurd. De producenten van de artikelen slagen er in meer en meer uiteenlopende zaken aan elkaar te koppelen. Deze zijn vervolgens steeds moeilijker weer te ontkoppelen, zodat er bepaalde knooppunten ontstaan. Deze knooppunten vertegenwoordigen zogenoemde 'harde kennis' of feiten.

Wetenschap kenmerkt zich door het vermogen om de bestaande orde te transformeren en verrassende en nieuwe verbanden te leggen. Daarbij bouwen wetenschappers voort op het werk van anderen. Zo is aan een goedfunctionerend protocol voor reanimatie een aanzienlijke hoeveelheid van heterogene elementen gekoppeld: het functioneren van reanimatieapparatuur, procedures inzake een snel en veilig transport van patiënten naar het ziekenhuis toc, een rolverdeling tussen artsen en verpleegkundigen (wie mag de dood constareren?), reanimatietechnieken, (eerdere) wilsverklaringen, eventueel de rol van de familie en tenslotte regels en routines met betrekking tot het defibrilleren. Uit deze heterogene orde van apparatuur, procedures, mensen en technieken kristalliseert een (standaard) aanpak van patiënten met een plotselinge adem- en/of hartstilstand uit (Timmermans 1998). Verschillende onderzoeken hebben laten zien dat praktijken door de introductie van standaarden niet volledig gedetermineerd worden, maar dat er nog steeds ruimte voor onderhandeling blijft (Timmermans \& Berg 1997; Mesman 2002).

In tegenstelling tot het traditionele beeld over wetenschap en praktijk, het zogenoemde diffusiemodel, wordt door Latour een translatiemodel geschetst. Bij het diffusiemodel wordt de maatschappij als ontvanger van de resultaten van wetenschappelijk onderzoek beschouwd; ware kennis wordt verspreid en vindt haar weg naar de praktijk. De kennis kan probleemloos meegevoerd worden vanuit de handboeken naar de plaatsen waar behoefte is aan deze kennis, bijvoorbeeld bij normering en regulering. In tegenstelling tot het diffusiemodel moet er bij het translatiemodel echter eerst veel werk verzet worden, voordat claims als ware kennis door het leven kunnen gaan. Hierin zijn autoriteiten, instituten en instrumenten, bijvoorbeeld computers, een voorwatarde voor succes. De maatschappij spcelt hierbij cen belangrijke rol. Zij ontvangt en verspreidt geen ware kennis, maar vormt een infrastructuur warin, doordat er veel 
werk wordt verzet, kennisclaims worden verplaatst en vertaald (deze dubbele beweging wordt door Latour een translatie genoemd). Zelfs al worden claims, bijvoorbeeld zorgvuldigheidsregels, gedurende langere tijd op dezelfde manier geformuleerd, dan nog verandert hun feitelijke rol en betekenis door een andere inbedding. Sommige kennis is 'harder', doordat ze is ingebed in een steviger netwerk van verscheidene koppelingen en relaties. Om kennisproductie op deze manier te begrijpen, moet onderzocht worden hoe kennisclaims in een maatschappelijke infrastructuur c.q. in netwerken ingebed raken.

De zorgvuldigheidseisen voor euthanasie zijn gevormd in een heterogeen netwerk van overheidsrapporten, jurisprudentie, professionele taakverdeling, sinds halverwege de jaren negentig de Wet op de lijkbezorging en inmiddels de Wet toetsing van levensbeëindiging op verzoek en hulp bij zelfdoding. In dit netwerk spelen onder andere juristen en ethici een belangrijke rol als producenten en consumenten van artikelen en boeken. Wat in de ene tekst een conclusie is, is in de volgende tekst een argument. Zo is het onderscheid van Leenen tussen euthanasie en schijngestalten van euthanasie eerst een conclusie, die hij trekt op basis van een op dat moment innovatieve redenering. Deze conclusie kan vervolgens door een rechter worden overgenomen bij de beoordeling van een rechtszaak over euthanasie. Er heeft dan een translatie plaatsgevonden, in de zin van een verplaatsing van professionele literatuur naar de rechtszaal (de conclusie in de ene tekst wordt argument in een andere context: jurisprudentie) en een vertalingvan 'wetenschappelijke' discussiebijdrage naar juridisch criterium (er wordt een nieuwe betekenis aan gegeven, namelijk een onderscheidend vermogen bij het beoordelen van wat in de jurisprudentie als euthanasie wordt beschouwd). Voorwaarde voor deze translaties is een infrastructuur van mensen, instanties en materialen (jurisprudentie, reksten, euthanatica), ofwel een heterogeen netwerk.

De huidige normering en regulering van euthanasie is het resultaat van de manier waarop een uitgebreid netwerk van heterogene relaties is opgebouwd. Bijvoorbeeld overheidscommissies die zich bogen over een advies met betrekking tot euthanasie, rechtszaken over euthanasie die aangaven wat er precies speelde, rechtbanken die een vonnis uitspraken over bepaalde casus, regels en afspraken met betrekking tot de keuze voor het euthanaticum, toekennen van specifieke competenties aan artsen, verrichten van wetenschappelijk onderzoek naar de praktijk van euthanasie (Commissie Remmelink), vastleggen van de rol van verpleegkundigen en ook procedures rond de verslaglegging, de zogenoemde 'dossierplicht'. Door te onderhandelen werden in dit netwerk bondgenoten geworven, die het idee van (wettelijke) regulering van euthanasie konden doorgeven. Juristen en ethici hebben door het produceren van teksten over verschillende casus, door op te treden als getuige-deskundige of in hun commentaren op een rechtszaak aan dit netwerk rond euthanasie meegebouwd. ${ }^{4}$ 
Deze teksten worden weer door collega's beoordeeld op de geloofwaardigheid van de claims en op de vraag of deze wel binnen de in her vakgebied gangbare aanpak vallen. Niet alleen de inhoud van de claim, maar ook de reputatie van de producent van de tekst is van belang voor de geloofwaardigheid. De volgende vraag is dan of de beoordeelde tekst weer gebruikt kan worden door de collegaethicus of collega-jurist om zelf een nieuwe tekst te produceren. Als de claim wordt overgenomen dan wordt de status ervan stabieler. Dit verhoogt de kans dat de claim (in aangepaste vorm) ook weer door andere collega's wordt gebruikt. Door dit werk ontwikkelt zich een web van met elkaar verbonden teksten, over in dit geval de regulering van euthanasie. ${ }^{5}$ Die regulering verloopt niet volgens een vooraf bepaalde of voor de hand liggende aanpak, maar is het resultaat van de vorming van het netwerk.

Binnen dat netwerk is sprake van een toenemend aantal bindingen of knooppunten. Bepaalde concepten raken verbonden met een zich tegelijkertijd ontwikkelende uitvoeringspraktijk, waardoor het op een gegeven moment zeer lastig is om bepaalde verhoudingen te veranderen. $\mathrm{E}_{\mathrm{r}}$ is dan een zekere mate van vertrouwen in de gegenereerde knooppunten. Het is bijvoorbeeld uiteindelijk de arts geworden die als enige straffeloos euthanasie kan toepassen, mits hij zich aan bepaalde voorwaarden houdt. De arts staat dus centraal bij het toepassen van euthanasie, hij geniet maatschappelijk vertrouwen. Dat verklaart ook in belangrijke mate waarom de pil van Drion - een alternatief voor het toepassen van euthanasie door een arts - bijvoorbeeld tot dusverre geen sterke positie heeft. Toen dit voorstel begin jaren negentig door Drion, oud-hoogleraar burgerlijk reche en oud-raadsheer in de Hoge Raad, aan de discussie over cuthanasie werd gekoppeld, was er al een stevige koppeling tussen arts en euthanasic tot $^{\prime}$ stand gekomen in het nerwerk. Drion wilde met deze pil een maximale zelfbeschikking voor alleenstaande ouderen van vijfenzeventig jaar en ouder bereiken; het zelfgewilde einde van oude mensen zónder bemiddeling van artsen (Drion 1992). Met dit middel zouden ouderen zelf moeten kunnen bepalen wanneer ze uit het leven willen stappen. Het omzeilen van de arts in geval van euthanasie of hulp bij zelfdoding bleek echter een uiterst lastige zaak. Deze pil is dan ook, tot op heden, geen realiteit geworden.

Om inzicht te krijgen in (de verhouding tussen) normering en regulering rond levensbeëindigend handelen zijn teksten hierover bestudeerd. ${ }^{6}$ Daarbij is speciale aandacht besteed aan commentaar op jurisprudentie en reacties op besluitvorming. De vraag is hoe het netwerk rond normering en regulering van euthanasie tot stand is gekomen. Om die vraag te beantwoorden worden de zorgvuldigheidseisen 'gedeconstrueerd', dat wil zeggen dat het werk dat eraan vooraf is gegaan zichtbaar wordt gemaakt. Of anders gezegd, de zwarte doos van de zorgvuldigheidseisen wordt opengemaakt. Vervolgens wordt in dit hoofdstuk onderzocht wat normering en regulering betekenen voor de rol en verhou- 
ding van recht en ethiek. Daarbij wordt er van uitgegaan dat normatieve en juridische kennisclaims niet 'kant-en-klaar' inzetbaar zijn, maar dat pas uit de onderhandelingen duidelijk wordt welke betekenis hieraan wordt toegekend. Hoe dat precies gebeurt vormt het object van studie in dit hoofdstuk.

\section{De praktijk van levensbeëindigend handelen: een heterogene orde}

\section{Voorwaarden, adviezen en een rechtszaak}

In de jaren zeventig keerde de vraag of 'euthanasie' altijd strafbaar zou moeten zijn voortdurend terug in de literatuur. Er was behoefte aan een normatief (sturend) kader met betrekking tot 'euthanasie', want er waren geen concrete normen of voorwaarden voor (Ekelmans 1972). Ten eerste was er op voorhand geen instantie of autoriteit waaraan de oplossing van het vraagstuk direct gekoppeld kon worden. Ten tweede kon het vraagstuk niet tegen het licht van een bestaande juridische of ethische standaard gehouden worden. De voor de hand liggende koppeling naar art. 293 van het Wetboek van Strafrecht, waarin een verbod op 'euthanasie' (het een ander op zijn uitdrukkelijk en ernstig verlangen van het leven beroven) staat te lezen werd wel gelegd. Niettemin werd beweerd dat het begrip eurhanasie nier in de Nederlandse wetgeving zou voorkomen (Rang 1972a).

Aan de hand van verschillende koppelingen, die op hun beurt bestendigd worden, ontwikkelen zich netwerken. Deze netwerken verschaffen de benodigde 'hardheid' voor de normering en de regulering. De juriste Vin Till deed een voorstel voor bepaalde normen, door deze impliciet in haar definitie van euthanasie te verwerken (Van Till-d'Aulnis de Bourouill 1973: 46). Haar voorstel was om van euthanasie te spreken indien er 'sprake is van een levensverkortende opzettelijke gedraging die primair in het belang van de patiënt is en die dient om een goede dood mogelijk te maken voor een ongeneeslijk zieke patiënt die subjectief ondraaglijk lijdt' (p. 48). De potentiële strafbaarheid van euthanasie is af te lezen uit de manier waarop euthanasie door Van Till werd gedefinieerd. De aangegeven eisen vormden een rechtvaardigingsgrond. Bovendien liet de definitie zien welke waarde werd gehecht aan de rol van de patiënt (her gaat om diens belang) en de toestand van de patiënt (ongeneeslijk ziek en subjectief ondraaglijk lijden).

Een opening naar een mogelijk 'geoorloofde' wijze van levensbeëindigend handelen was ook door de Commissie Medische Ethiek van de Gezondheidsraad aangegeven. ${ }^{7} \mathrm{ij}$ wilde - met opzet - geen algemene normen hiervoor geven. ${ }^{8}$ Het advies van de Gezondheidsraad betekende ten eerste dat er op overheidsniveau actie was ondernomen om het onderwerp van levenshec̈indiging een plaats te geven. De problematiek van de levensbeëindiging werd daarbij 
expliciet binnen een (beperkte) medische context beschouwd; het eventueel toepassen van euthanasie werd aan een arts voorbehouden (Gezondheidsraad 1972). 'Ten tweede werd uit het rapport duidelijk dar de Gezondheidsraad de problematiek wilde oplossen via het onderscheid tussen actieve en passieve euthanasie. Actieve euthanasie zou verboden zijn, maar passieve euthanasie zou in bepaalde omstandigheden toelaatbaar geacht moeten worden. Men probeerde de zaak te ordenen door deze koppeling, dat wil zeggen actieve euthanasie als ongeoorloofd en passieve euthanasie als, onder omstandigheden, geoorloofd. Maar in een rechtszaak in Leeuwarden over een geval van 'actieve vrijwillige euthanasie' bleek deze koppeling geen stand te houden. Door de rechtbank van Leeuwarden werd namelijk een andere normatieve meetlat gehanteerd: het onderscheid tussen vrijwillige euthanasie (onder bepaalde omstandigheden geoorloofd) en niet-vrijwillige euthanasie. Kortom, het advies van de Gezondheidsraad werd niet door de rechtspraak versterkt.

Deze uitspraak in de zaak Postma vormde de volgende schakel in het netwerk rond levensbeëindigend handelen. Bij deze rechtszaak ging het om een opzettelijk beëindigen van het leven, op uitdrukkelijk en ernstig verlangen van een moeder door haar dochter, de huisarts Postma (in de terminologie van destijds een geval van actieve, vrijwillige euthanasie). Let wel, het ging hier om het roepassen van euthanasie door een arts, maar dat was niet de behandelend arts. Bij het proces stond Mevrouw Postma terecht op grond van het overtreden van art. 293 van het Wetboek van Strafrecht. De geneeskundig inspecteur van de volksgezondheid van Friesland, Kijlstra, trad in deze zaak op als getuige-deskundige. ${ }^{10}$ Deze getuige-deskundige stelde onomwonden vast dat 'de gemiddelde medicus in Nederland het niet meer als juist aanvaardt, het leven van een patiënt te rekken tot het bittere einde', indien: $x$ ) de patiënt door ziekte of ongeval ongeneeslijk ziek is; 2) de patiënt zijn lichamelijk of geestelijk lijden subjectief ondragelijk is; 3) de patiënt, eventueel voorafgaand schriftelijk, te kennen heeft gegeven het leven te willen beëindigen; 4) de stervensperiode van de patiënt naar medisch oordeel is ingegaan of zich heeft aangekondigd; 5) door een arts, te weten de behandelende arts of medisch specialist, dan wel in overleg met die geneesheer, wordt ingegrepen (Ekelmans 1973). Op dat moment was deze uitspraak nog weinig 'hard', de voorwaarden hadden in ieder geval niet de status van de huidige zorgvuldigheidseisen in de discussie over levensbeëindigend handelen.

De normen waarnaar Kijlstra in zijn betoog verwees, waren gebaseerd op de opvatting van de gemiddelde medicus in Nederland (Redactioneel 1973). Hij beriep zich met deze claim op een klaarblijkelijk gangbare ethiek (Sanders 1973). Dit oordeel werd door de rechtbank Leeuwarden in grote lijnen overgenomen." Dat betekent dat het advies van de Gezondheidsraad om actieve euthanasie te verbieden niét werd overgenomen. Het oordeel van de rechter kwam er namelijk op neer dat actieve vrijwillige euthanasie onder bepaalde om- 
standigheden zou zijn toegestaan. De uitspraak van deze ene rechtbank betekende echrer niet dat er meteen een breed gedeeld of algemeen normatief kader voor het toepassen van (actieve vrijwillige) euthanasie voor handen was.

De zaak Postma leverde middels twee belangenverenigingen een patiëntenperspectief binnen het netwerk op. Naar aanleiding van de zaak Postma werden namelijk de Nederlandse Vereniging voor Vrijwillige Euthanasie (NVVE) en de Stichting Vrijwillige Euthanasie (sVE) opgericht. De Vereniging had als doelstelling: 'de sociale annvaarding van de vrijwillige eurhanasie en daaruir voortvloeiende legalisatie'. De Stichting had als doelstelling: 'de bewuste meningsvorming betreffende de problematiek van de stervensbegeleiding te bevorderen' (Muntendam 1977: 8). Verscheidene vooraanstaande ethici en juristen hebben bij zowel de NVVE als de SVE in het bestuur gezeten.

In professionele kring riep het Leeuwarder euthanasieproces slechts een gering aantal - kritische - reacties op. ${ }^{12}$ Met name van de kant van de artsen was er relatief weinig reacrie gekomen op het arrest van Leeuwarden. De inbreng van artsen in het netwerk kwam op het moment dar de KNMG een advies over euthanasie uitbracht. In haar advies van november 1973 (dat overigens ruim een jaar later pas in het blad Medisch Contactwerd gepubliceerd), stelde de KNMG dat het bij euthanasie moest gaan om ongeneeslijk zieken, waarbij het stervensproces was ingetreden (KNMG 1975). ${ }^{17}$ Futhanasie zou slechts overwogen mogen worden, indien de patiënt er uit eigen beweging om vroeg (hiermec werden her punt van de vrijwilligheid van de rechtbank Leeuwarden en de inzet van de beide verenigingen bestendigd), de arts geen mogelijkheid tot verbetering zag en de prognose beoordeeld was met behulp van uitgebreide diagnostiek, curatieve therapie gefaald had en tenslotte, als de behandelend arts de raad van een collega had gevraagd. Het verschil in de voorwaarden, geformuleerd door de KNMG en de rechrbank Leeuwarden, zat in her lijden van de patiënt. Het ondragelijk lijden werd door de KNMG niet expliciet als voorwaarde genoemd, wél dar het laatste woord altijd aan de behandelend arts was, omdat deze de euthanasie ook uiteindelijk zou moeten toepassen en over de benodigde medische kennis zou beschikken. De KNMG stelde dus expliciet dat de behandelend arts de euthanasie zou moeten uitvoeren, hetgeen bij de zaak Leeuwarden niet het geval was geweest.

Het is duidelijk dat de verschillende acties die werden ondernomen om voorwaarden op te stellen en normatieve grenzen te bepalen voor het toepassen van euthanasie, niet naadloos in elkaars verlengde lagen. Elke inbreng bracht een verschuiving teweeg. Begin jaren zeventig hadden de door de rechtbank van Leeuwarden en de KNMG geformuleerde voorwaarden dus allerminst de status van officiële (door de overheid gestelde) richtlijnen voor levensbeëindigend handelen. Wel waren enkele van deze voorwaarden voor her eerst formeel gehanteerd, namelijk in een rechtszaak. Het was echter onduidelijk of deze als leidraad voor levensheëindigend handelen in de medische prakrijk konden fun- 
geren. De situatie was wat dat betreft onzeker. Bij jurisprudentie is er altijd de vraag in hoeverre deze ene specifieke situatie als voorbeeld kan dienen voor toekomstige gevallen. Kennelijk was er bij artsen aanvankelijk weinig vertrouwen in deze voorwarden, want het duurde nog een aantal jaren voordat er gesproken kon worden van een redelijke hoeveelheid jurisprudentie over levensbeëindigend handelen in een medische context.

\section{Zorgvuldigheidseisen voor het toepassen van euthanasie}

Uit de jurisprudentie, adviezen en voorstellen rond het bepalen van voorwaarden voor het toepassen van euthanasie waren begin jaren tachtig nog geen stabiele knooppunten gevormd. Het was onduidelijk wie en onder welke voorwaarden euthanasie of hulp bij zelfdoding zou mogen toepassen. Eind jaren zeventig werd door een arts in dit verband een pleidooi gehouden voor een nieuw soort functionaris; de zogenoemde 'sterfwaarder' (Buijs 1979). Volgens deze arts was her idee dat euthanasie een geneeskundige aangelegenheid zou zijn onjuist. ${ }^{\mathrm{I}}$ Er zou een aparte Kamer van de Rechtbank moeten komen die zich uitsluitend met euthanasie zou bezighouden. De sterfwaarders zouden mensen van hbo-niveau moeten zijn met kennis van zaken op het terrein van de psychologie, sociologie, farmacologie en het recht. Kortom, het zouden mensen moeten zijn met inzicht in de omstandigheden en kennis van de technische kanten van het toepassen van euthanasie.

Eind jaren zeventig lag dus zelfs voor een deel van de artsen nog open wie euthanasie zou mogen toepassen. Dit betekent dat - hoewel dit nu nogal vreemd voorkomt - het mogelijk was dat een ingeschakeld lid van de NVVE aan een 67 -jarige vrouw in het voorjaar van $198 \mathrm{r}$ hulp bij zelfdoding verleende. De vrouw had meermalen om euthanasie verzocht, haar huisarts was echter niet bereid geweest haar verzoek in te inwilligen. ${ }^{\text {Is }}$ Daartoe zocht ze contact met mevrouw Wertheim, wiens naam ze van haar vroegere huisarts had doorgekregen. Mevrouw Wertheim stond bekend als een actief lid van de Nederlandse Vereniging voor Vrijwillige Euthanasie en zij besloot de vrouw te helpen, nadat ze haar een aantal keren had gesproken (Enthoven 1988: 78). In november 1981 stond mevrouw Wertheim terecht wegens het verlenen van hulp bij zelfdoding (art. 294 Wetboek van Strafrecht). De Rotterdamse rechtbank stelde dat hulp bij zelfdoding niet altijd strafbaar hoefde te zijn, mits aan een aantal voorwaarden zou zijn voldaan. Bij het opstellen van deze voorwaarden werd in grote lijnen het concept van de rechtbank Leeuwarden overgenomen. Eén van de voorwaarden luidde dat er tenminste een arts 'betrokken' moest zijn bij de hulp bij zelfdoding, onder andere om de juiste methode te bepalen. ${ }^{16}$

Hoewel aan het algemene karakter van de voorwarden uit Leeuwarden volgens sommigen getwijfeld kon worden, ze wellicht op arbitraire wijze tor 
stand waren gekomen en het om twee verschillende zaken ging (enerzijds euthanasie en anderzijds hulp bij zelfdoding), bleek dat ze niettemin in de jurisprudentie als baken voor de normering van euthanasie fungeerden. Dit betekent dat ondanks deze kanttekeningen het concept van de voorwaarden en de specifieke invulling ervan meer verankerd raakte. In een eventueel volgende rechtszaak zou het moeilijker worden om ze niet te hanteren, daar zou dan een motivatie voor gegeven moeten worden. De ethicus Kuitert bevestigde het voorlopig normatieve en regulatieve kader eveneens in zijn boek Een gewenste dood dat in hetzelfde jaar als de zaak Wertman speelde verscheen. Hij stelde dat vanuit moreel perspectief het onderscheid tussen op verzoek en niet op verzoek bij de beoordeling van euthanasie het meest relevant was (Kuitert 1981: 37). De voorwaarden begonnen te functioneren als een richtinggevend normatief kader.

Deze functie werd nog eens versterkt doordat Leenen, hoogleraar sociale geneeskunde en gezondheidsrecht, de twee rechtszaken (Leeuwarden 1973 en Rotterdam 1981) nauwkeurig vergeleek. De verplaatsing van de voorwaarden van Leeuwarden naar Rotterdam kan het best worden geïllustreerd door de citel die Leenen aan zijn artikel meegaf: 'Euthanasie en hulp bij zelfdoding. Van Leeuwarden naar Rotterdam'. Door de verschillen en overeenkomsten op een rijtje te zetten bracht Leenen een koppeling tussen beide uitspraken tot stand. ${ }^{17}$ Hij beschouwde de twee vonnissen als een doorbraak in de rechtspraak, omdat er 'juridische openingen' waren gemaakt voor een zich ontwikkelende hulpverleningspraktijk (Leenen 1982). In zijn commentaar op beide vonnissen benadrukte Leenen dat euthanasie door een arts moest gebeuren (Leenen 1982: IOs). Het vonnis van Rotterdam was minder strikt ten aanzien van de uitvoering door een arts dan het vonnis van Leeuwarden en Leenen keurde deze onduidelijkheid af; de uitvoering van euthanasie en hulp bij zelfdoding moesten door een arts gebeuren. Hij gaf hiervoor verschillende argumenten. ${ }^{18}$ Met deze gedetailleerde vergelijking van de twee rechtszaken bekrachtigde Leenen de vorm waarin bij beide rechtszaken een normatief kader, namelijk middels het concept van een rijtje voorwaarden, tot stand was gekomen. Door het normatieve kader te bestendigen bouwde hij mee aan het tot stand komen van een netwerk rond de normering van euthanasie en hulp bij zelfdoding. Bovendien maakte hij veel werk van het standpunt dat euthanasie alleen door een arts zou mogen worden toegepast. De interventie van Leenen betekende dus een verplaatsing en vertaling (translatie) van de voorwaarden.

Het juridische kader op basis van de twee rechtszaken bood een perspectief om hulp bij zelfdoding en euthanasie op ethisch verantwoorde wijze te regelen. ${ }^{19}$ Een betekenisvolle schakel bij het 'hard' worden van de zorgvuldigheidseisen vormde de publicatie van her tweede standpunt van de KNMG. De onduidelijkheid over welke voorwaarden zouden moeten gelden bij het toepassen van 
euthanasie hing samen met de stand van zaken in de medische ethiek in deze periode. Mede door de pluriformiteit in de medische ethiek was er grote onzekerheid over eventuele normatieve richtlijnen die voor euthanasie en hulp bij zelfdoding zouden kunnen gelden. Deze onzekerheid was voor de KNMG aanleiding om begin 1984 een serie artikelen over medische ethiek in het artsenblad Medisch Contact op te starten. ${ }^{20}$ In die onzekere normatieve context moet de wijziging van het standpunt van het hoofdbestuur van de KNMG bezien worden.

De ontwikkelingen in de rechtspraak waren volgens het hoofdbestuur van de KNMG een reden om het standpunt van 1973 te herzien. Een tweede aanleiding om 'met een standpunt naar buiten te komen is mede het feit dat de Staatscommissie Euthanasie daarom heeft gevraagd, ten einde het standpunt van de KNMG bij haar werk te betrekken' (KNMG 1984; 990). ${ }^{21}$ Ten derde stelde de KNMG dat ze uitging van het 'feit dat euthanasie wordt toegepast', maar dat er 'grote rechtsonzekerheid bestaat rond euthanasie, zowel voor artsen als patiënten. Het hoofdbestuur is van mening dat daaraan zo spoedig mogelijk een eind moet komen' (p. 990). In het standpunt van het hoofdbestuur werden door de KNMG voorwaarden geformuleerd voor de toepassing van euthanasie en hulp bij zelfdoding. Dit betekende dat de KNMG meeging in het gecreëerde normatieve kader en dit bestendigde door de voorwaarden vanuit een KNMG-invulling te herformuleren onder de noemer 'Te hanteren zorgvuldigheidseisen bij verzoeken om euthanasie' (KNMG 1984: 994). ${ }^{22}$ De KNMG sprak niet (meer) van voorwaarden, maar van te hanteren zorgvuldigheidseisen. Het hoofdbestuur stelde dat, uit het oogpunt van rechtszekerheid, de arts die aan de gestelde zorgvuldigheidseisen zou voldoen er redelijkerwijs op mocht rekenen dat hij van rechtsvervolging werd ontslagen (p. 996). Hiermee werd een koppeling aangebracht tussen de zorgvuldigheidseisen (als normatief kader voor euthanasie) en het creëren van rechtszekerheid voor de arts. De artsen werden dus in het netwerk opgenomen door middel van de belofte van rechtszekerheid. De publicatie van dit standpunt heeft ook een omslag in de opvatting van veel artsen betekend. ${ }^{23}$ Dat betekent niet dat artsen ook meteen een soevereine positie hadden verworven in het netwerk rond euthanasie. De zorgvuldigheidseisen betekenden ook dat er iets gevraagd werd van artsen. Zo moesten ze het verzoek van de patiënt beoordelen, de mate van diens lijden interpreteren, een euthanasiedossier van de patiënt aanleggen en de levensbeëindiging op medisch-farmacologisch verantwoorde wijze moeten uitvoeren.

De activiteiten rond de normstelling voor het toepassen van euthanasie kwamen vanuit meerdere invalshoeken. Uit diverse zaken, zoals: impliciete voorwaarden in een omschrijving c.q. definitie van euthanasie, 'omstandigheden' waaronder euthanasie geoorloofd zou kunnen zijn, een getuige-deskundige verklaring, formele voorwaarden bij rechtszaken en zorgvuldigheidseisen in een advies van de KNMG werd een bepaalde orde opgebouwd. Ten eerste vond het 
idee her en der ingang dat euthanasie geoorloofd zou moeten zijn als aan een aantal voorwaarden was voldaan. Ten tweede werd de invulling van die voorwaarden, na een periode van relatieve vrijblijvendheid, steeds meer beperkt en daarmee werd het netwerk sterker. Zo was het bijvoorbeeld aanvankelijk nog geen uitgemaakte zaak of de uitvoering van euthanasie of hulp bij zelfdoding in handen van een arts moest liggen, en zo ja of dit ook de behandelend arts moest zijn. De koppeling tussen euthanasie en de medische professie (in plaats van bijvoorbeeld verpleegkundigen) werd echter steeds hechter, zodat het nu dan ook moeilijk voorstelbaar is dat euthanasie ook door anderen dan artsen uitgevoerd zou mogen worden. Met het standpunt van de KNMG uit 1984 was het een uitgemaakte zaak dat het toepassen van euthanasie alleen aan artsen zou zijn voorbehouden. De zorgvuldigheidseisen zijn het resultaat van de manier waarop het nerwerk rond medische beslissingen rond het levenseinde tot stand is gekomen. Her idee van de zorgvuldigheidseisen werd door steeds meer mensen en vanuit andere invalshoeken (in gewijzigde vorm) overgenomen. Het concept van de zorgvuldigheidseisen voor euthanasie en hulp bij zelfdoding en de specifieke invulling ervan was niet het resultaat van de stand van zaken in de medische ethiek op dat moment; er was kennelijk geen 'objectief ijkpunt' binnen de medische ethiek waarlangs de problematiek gelegd kan worden. Er was geen consensus over normatieve richtlijnen voor euthanasie en hulp bij zelfdoding. Dit betekent dat er geen ethische kennis vanuit bepaalde handboeken rechtstreeks naar het nieuwe vraagstuk van levensbeëindigend handelen kon worden overgeheveld. Voorstellen voor nieuwe normen en regels vonden tegelijkertijd plaats; de eerste vormen niet noodzakelijk of logisch een voorwaarde voor de tweede. Tegelijkertijd en in samenhang met her concept van de zorgvuldigheidseisen ontwikkelen zich normering en regulering voor levensbeëindigend handelen.

Artsen, strafbaarheid en rechtsonzekerheid

\section{Een juridische grondslag voor het straffeloos kunnen toepasser van euthanasie}

In de tweede helft van de jaren tachtig konden de zorgvuldigheidseisen niet meer genegeerd worden. De zorgvuldigheidseisen voor euthanasie hadden als concept een relatief stabiele status en daarmee ook (maatschappelijk) vertrouwen verworven binnen het netwerk. Hiermee leek de vraag of euthanasie en hulp bij zelfdoding (door een arts) mogelijk zouden moeten zijn, te zijn beantwoord met een ' ja, mits...'. Als in een derde rechtszaak dit normatieve kader wederom wordt gehanteerd en zelfs verruimd, wordt echter duidelijk dat er ook nog een tweede probleem opgelost moet worden: hoe kunnen euthanasie en 
hulp bij zelfdoding door een arts worden toegepast zónder dat deze strafrechtelijk vervolgd wordt? Dit probleem werd in de discussie wel vertaald als een probleem van rechts(on)zekerheid (voor artsen, pariënten en de rechter) en rechtsongelijkheid. Deze paragraaf laat zien hoe hiermee om wordt gegaan bij pogingen tot regulering van euthanasie en hulp bij zelfdoding.

$\mathrm{Na}$ Leeuwarden en Rotterdam leek het voldoen aan bepaalde criteria een soort garantie voor artsen om niet vervolgd te worden. Een derde rechtszaak leek dit kader zelfs te verruimen: het Alkmaarse euthanasie-vonnis in 1983. Zo werd het criterium van ondraaglijk lijden verruimd tot een door de patiënt ervaren ondraaglijkhcid van het leven. Een huisarts had het leven beëindigd van een 95-jarige patiëntie die hier herhaaldelijk om had gevraagd. Net als bij de zaak Postma en de zaak Wertheim beriep de verdachte, de huisarts Schoonheim, zich op het ontbreken van materiële wederrechtelijkheid. ${ }^{24}$ Het ontbreken van de materiële wederrechtelijkheid is een mogelijkheid om een strafbaar feit te rechtvaardigen, waardoor dit niet meer strafbaar is, een zogenoemde strafuitsluitingsgrond. Het ontbreken van de materiële wederrechtelijkheid werd volgens de rechtbank in Alkmaar in dit geval gefundeerd door het zelfbeschikkingsrechr. Deze juridische constructie van het ontbreken van materiële wederrechtelijkheid werd dus 'vertaald' naar de praktijk voor het toepassen van euthanasie. Dat gebeurde door er het concept van zelfbeschikking aan te verbinden. ${ }^{25}$ Hoewel Schoonheim niet aan één van de drie bijzondere voorwaarden van de rechtbank van Rotterdam had voldaan, werd hij wel - in tegenstelling tot Postma en Wertheim - van alle rechtsvervolging ontslagen. ${ }^{26}$

Dit vonnis stuitte op weerstand, niet zozeer vanwege de verruiming van de voorwaarden, maar vanwege de rol van het recht in deze. Schalken, advocaatgeneraal van het Gerechtshof in Amsterdam, ging tegen het vonnis van Alkmaar in hoger beroep. 'Door de beslissing van de $\mathrm{Rb}$. Alkmaar is onzekerheid ontstaan over de criteria die ten aanzien van strafbare euthanasie moeten worden aangelegd en dus ook ten aanzien van de criteria die voor het Openbaar Ministerie richtsnoer vormen bij het vaststellen van zijn vervolgingsbeleid. Die criteria bepalen in de praktijk tevens de grenzen, waarbinnen het handelen van de medicus naar diens oordeel straffeloos zou kunnen geschieden. Die grenzen zijn nu drastisch verlegd. De onduidelijkheid ontstaat doordar de recente beslissingen over euthanasie alle op hetzelfde niveau tot stand zijn gekomen. Waarom zou het oordeel van de Rb. Alkmaar maatgevender zijn dan dat van de Rb. Leeuwarden of Rotterdam? Medici zullen uit de verschillende opvattingen naar gelang hun persoonlijke voorkeur een keuze kunnen maken die hun handelen moet rechtvaardigen. Dat kan tot rechtsonzekerheid aanleiding geven in die gevallen, waarin een arts aangifte van euthanasie overweegt. Daarnaast kan tevens een gevoel van rechtsongelijkheid ontstaan, indien de ingestelde strafvervolging wordt gebaseerd op andere criteria dan die waaraan de medicus in alle 
redelijkheid meende zijn handelen te mogen toetsen, terwijl de medicus in een ogenschijnlijk hetzelfde geval niet wordt vervolgd' (Schalken 1984: 38). Schalken stelde in zijn requisitoir dat actieve euthanasie, ook onder bepaalde omstandigheden, slechts straffeloos kon blijven indien er sprake was van medische onvermijdelijkheid of bij strikt persoonlijke, de medicus dwingende omstandigheden. Hij vond niet dat er via de weg van het recht een nieuwe leidraad voor het medisch normbesef moest komen, in dit geval door aan het zelfbeschikkingsrecht juridische betekenis toe te kennen. Dat wil zeggen dat op grond van de motivatie van het zelfbeschikkingsrecht de wederrechtelijkheid aan het handelen in strijd met een wettelijke norm in materieel opzicht ontnomen zou worden. Schalken vond dat er eerst binnen de medische ethiek, in lijn met het model dat in het begin van dit hoofdstuk is aangehaald - eerst duidelijkheid over normen, dan pas regels opstellen - consensus moest zijn. Hij verwees de euthanasiediscussie terug naar de medische praktijk. Volgens hem hoorde deze discussie 'binnen de medische ethiek i.h.a. en binnen de vertrouwensrelatie tussen arts en patiënt i.h.b.' gevoerd te worden (p. so). Door het zelfbeschikkingsrecht een plaats te geven in de juridische grondslag voor het straffeloos kunnen toepassen van euthanasie was de rechtbank volgens Schalken buiten haar bevoegdheden getreden Een dergelijk oordeel kon volgens Schalken alleen door de wetgever worden gegeven.

Dat er nu drie, inhoudelijk verschillende, uitspraken van rechtbanken waren inzake euthanasie en hulp bij zelfdoding werd door Schalken als een probleem van rechtsonzekerheid en rechtsongelijkheid getypeerd. De oorzaak hiervan lag volgens hem in de manier waarop her recht in dit vraagstuk intervenieerde. Hij waarschuwde voor te overspannen verwachtingen ten aanzien van het recht als probleemoplosser en pleitte voor terughoudendheid met betrekking tot regulering, 'zolang onduidelijk is waar de grens moer komen te liggen. Tal van vragen staan binnen de ethiek, zelfs binnen de medische beroepsmoraal, nog open: is de stervensfase al of niet een vereiste? Gaat het alleen om lijden in somatische zin of ook in psychiatrische zin? Geeft de wens van de patiënt of het inzicht van de arts de doorslag?' (Schalken 1985: 172). Er zou volgens Schalken eerst meer duidelijkheid in de medisch-ethische normen moeten zijn, voordat het recht serieus als scheidsrechter kon gaan optreden. Het recht zou volgens hem op de ethiek gefundeerd moeten worden. Maar het is duidelijk dat op dat moment het direct toepassen van ethische kennis in geen geval mogelijk was, vanwege de pluriformiteit in de ethiek.

Door de uitspraak van het Hof van Amsterdam leek er in de gegenereerde orde rond de regulering van euthanasie een barst te komen. Er ontstonden verwarring en onzekerheid over de tot stand gekomen orde. ${ }^{27}$ Omdat de arts Schoonheim het niet eens was met de uitspraak van het Hof van Amsterdam waarin het Alkmaarse vonnis werd vernietigd, volgde er een arrest van de Hoge 
Raad. Dit betekende dat er een nieuwe schakel, het hoogste rechrscollege in ons land, met het netwerk rond de normering en regulering van euthanasie verweven raakte. (Ook de NVVE was van mening dat er sprake was van een probleem van rechts(on)zekerheid. ' $Z$ ij hoopte echter dat er door middel van rechtszaken meer duidelijkheid zou komen, zodat patiënten zouden weten wat ze konden verwachten als bij hen de wens rot euthanasie leefde. 'Zij heeft dit 'proefproces' dan ook financicel gesteund en erop aangedrongen dat de procesgang zou worden voortgezet (Klijn 1985). Het beroep op het ontbreken van de materiële wederrechtelijkheid werd door de Hoge Raad afgewezen. Het Amsterdamse hof had volgens de Hoge Raad 'vergeten' om te beoordelen of de verdachte de plichten en belangen die in dit onderhavige geval tegenover elkaar stonden wel zorgvuldig " - in het bijzonder volgens de normen van de medische ethiek en met de kennis van zaken waarover hij uit hoofde van zijn beroep als medicus geacht moet worden te beschikken - tegen elkaar heeft afgewogen en daarbij een keuze heeft gemaakt die objectief beschouwd en gelet op de zich te dezen voordoende omstandigheden gerechtvaardigd was (beroep op noodtoestand of objectieve macht)' (Van Es \& Vroom-Kastelein 1986: 823). Met andere woorden, het hof had volgens de Hoge Raad niet alleen moeten onderzoeken of er sprake was van overmacht in de zin van psychische overmacht, maar ook of er sprake was van overmacht in de zin van een noodtoestand. Dit werd uitgelegd als een conflict tussen het houden aan wettelijke plichten en de normen binnen de medische ethiek. Deze redenering van de Hoge Raad betekende dat het argument van de juridische normering met betrekking tot het ontbreken van matcriële wederrechtelijkheid werd verworpen, ten gunste van een normering waarin de ethiek minder specifiek werd omschreven. Immers, bij de constructie van overmacht ging het niet nader aangeduid om 'normen in de medische ethiek', in tegenstelling tor het beroep op het ontbreken van de materiële wederrechtclijkheid dat op her zelfbeschikkingsrecht was gebaseerd.

De Hoge Raad was, net als her Hof, van mening dat nog niet gesproken kon worden van een reeds voldoende 'uitgekristalliseerde' algemene opvatting waardoor euthanasie als algemeen maatschappelijk aanvaardbaar kon worden beschouwd. Zij verwees daarmee de vraag, of euthanasie ethisch verantwoord kon worden toegepast, terug naar de medische praktijk.. Het netwerk rond de toepassing van euthanasie was niet stabiel genoeg om een doorbraak te genereren over de manier waarop euthanasie gereguleerd zou kunnen worden. Het lag nog 'open' op welke manier er versterking zou komen.

\section{Een twistpunt rond de regulering van euthanasie}

Dat er bij verschillende betrokkenen behoefte aan (enige vorm van) regulering was, staat buiten kijf. De vraag was echter hoé en wáár dat zou moeten gebeu- 
ren. Enerzijds werd er pluriformiteit c.q. onzekerheid binnen de medische ethiek geconstateerd, waardoor een oplossing middels jurisprudentie of wetgeving meer voor de hand zou liggen. Door een lid van de Tweede Kamer werd bijvoorbeeld een wetsvoorstel ingediend (het wetsontwerp Wessel-Tuinstra dat later als het wetsontwerp Kohnstamm zou doorgaan) ${ }^{29}$ Volgens de indienster was het hoog tijd dat er een eind kwam aan de heersende rechtsonzekerheid als gevolg van de jurisprudentie; de wetgever moest in actie komen. Anderzijds werd het vraagstuk terug op het bord van de medische professie (en de stand van zaken in de medische ethiek) gelegd. Kortom, er was verschil van mening over de vraag uit welke hoek de aanzet voor een oplossing moest komen.

De Hoge Raad had aangegeven dat wat hem betreft euthanasie een medisch probleem was. Dat betekende dat het aan het inzicht en het geweten van de arts werd overgelaten. Een arts moest, op grond van de heersende medische ethiek, zelf een beslissing nemen als hij met een verzoek om euthanasie werd geconfronteerd. Het reguleren van euthanasie werd aan de ethische reflectie van de medische professie overgelaten. Het recht zag dus voor zichzelf, in tegenstelling tot vaak geventileerde verwachtingen van het recht, niet automatisch de rol van probleemoplosser in deze kwestie weggelegd. Dit werd nog eens versterkt door de oplossing die Enschedé, een befaamd oud-hoogleraar strafrecht en oud-lid van de Hoge Raad, voorstelde. In een boek over 'toekomstig euthanasiebeleid', waarin hij zijn vele artikelen en lezingen over dit onderwerp had gebundeld, maakte Enschedé duidelijk dat er eigenlijk niet zo veel veranderd hoefde te worden. Nieuwe wetgeving zou dan ook overbodig zijn (Enschedé 1985). Het toepassen van euthanasie door artsen beschouwde Enschedé als een vorm van 'medische exceptie'. 'Artsen blijven (...) buiten het bereik van de straffende arm van de staat, indien en voor zover zij zich in hun professioneel gedrag richten naar de regels van de medisch-ethische standaard' (Enschedé 1985: 9). Enschedé beriep zich op rechts- en wetshistorisch onderzoek waaruit zou blijken dat het medische beroepsrecht al sinds $188 \mathrm{I}$ een ongeschreven rechrvaardigingsgrond was. ${ }^{30}$ Met andere woorden, de veranderde medische ethiek rechtvaardigde het roepassen van euthanasie door artsen, mits dit gebeurde op een wijze die overeenkwam mer de medisch-professionele standaard. Door Enschedé werden de veranderingen en verschuivingen in de medische ethiek dus niet als onduidelijkheid en probleem gezien, maar juist als legitimatie voor het handelen van de artsen. De geformuleerde zorgvuldigheidseisen waren als het ware vervat in de medisch-professionele standaard en Enschedé had kennelijk vertrouwen in de manier waarop artsen hiermee om zouden gaan. Enschedé kreeg steun van enkele collega-strafrechtjuristen (Langemeijer $\&$ Enschedé et al. 1986). De vraag hoé euthanasie te legaliseren, was volgens deze groep strafrechtjuristen een 'schijnprobleem'; er hoefde geen nieuwe juridische grondslag te worden gevonden of (nieuwe) wetgeving te worden gemaakt (p. 224). 
Uit een reactie op Enschedé bleek dat Leenen het niet eens was met diens voorstel. Hij vond een wijziging van het Wetboek van Strafrecht wél nodig (Leenen 1988a). ${ }^{31}$ In de strijd hierover was onder andere de medische ethiek punt van onderhandeling. Een bezwaar van het begrip medische exceptie was volgens Leenen ten eerste dat euthanasie geen medisch handelen was in de gebruikelijke zin (Leenen 1985: 416). Ten tweede vond Leenen het verwijzen naar de 'medische ethiek' een probleem. Het ging bij euthanasie 'niet om een medischethische aangelegenheid, maar om een algemeen ethisch vraagstuk. Het was niet aan de medische beroepsgroep om de normen met betrekking tot de euthanasie te bepalen.' Bovendien stelde hij dat bij medische ethiek het professionele kader ontbrak, omdat er geen in de medische ethiek algemeen geldende normen zouden bestaan. Hiervoor verwees Leenen naar het standpunt van de KNMG (p. 4I6). Ten derde verwees Leenen naar het verwerpen van de constructie van 'medische exceptie' door het hof van Leeuwarden (Leenen 1985: 415). ${ }^{32}$ Leenen toonde zich in dit artikel voorstander van regulering in de vorm van maatschappelijke controle waarbij de medische professie het vertrouwen van de maatschappij eerst voor zich moest winnen in plaats van het aan de medische soevereiniteit over te laten, zoals Enschedé had voorgesteld.

Het rapport van de Staatscommissie, dat in juli 1985 werd gepubliceerd, was bedoeld als bouwsteen voor het toekomstige euthanasiebeleid (Staatscommissie 1985$).{ }^{33}$ Eind jaren zeventig was er een voorstel gedaan om een Staatscommissie in te stellen die moest gaan adviseren over het toekomstige euthanasiebeleid. Een meerderheid van de commissie was van mening dat actie van de wetgever geboden was, omdat het niet duidelijk was of er uiteindelijk via de ontwikkeling van jurisprudentie rechtszekerheid zou komen. ${ }^{34}$ De commissie stelde voor om art. 293 van het Werboek van Strafrecht te wijzigen. ${ }^{35}$ Ze verwierp het beroep op de medische exceptie, de oplossing van Enschedé en consorten. In art. 293 zou een aantal zorgvuldigheidseisen - zoals geformuleerd in de jurisprudentie - moeten worden opgenomen. De zorgvuldigheidseisen werden wederom gereproduceerd, dat betekent dat ze steeds meer 'bondgenoten' hadden gevonden en als zodanig sterker waren geworden.

Het pleit rond de aard van de regulering van eurhanasie werd voorlopig beslecht met een advies van de Gezondheidsraad en een wetsvoorstel van de regering. ${ }^{36}$ De Gezondheidsraad was begin 1987 gevraagd advies uit te brengen over een aantal mogelijke regelingen rond euthanasie alsmede te adviseren over de zorgvuldigheidseisen. In zijn advies stelde de Gezondheidsraad dat de strafwettelijke constructie van de overmachtsituatie (zoals voorgesteld door de Hoge Raad) als een gegeven werd beschouwd (Gezondheidsraad 1987: 13). Vervolgens stelde de raad voor om een zestal zorgvuldigheidseisen vast te stellen (p. 5). Uiteindelijk diende de regering in december 1987 een wetsvoorstel in. Daarin stond dat de arts zich kon beroepen op art. 40 Wetboek van Strafrecht 
(overmacht in de zin van noodtoestand). Tevens werd voorgesteld om in een apart artikel van de Wet Uitoefening Geneeskunst (wUG) de zorgvuldigheidseisen neer te leggen waaraan moest zijn voldaan wilde een arts zich op art. 40 van het Wetboek van Strafrecht kunnen beroepen. Dit wetsvoorstel richtte zich dus slechts op één vorm van regulering van het euthanasie vraagstuk: wetgeving. Uit de ontwikkelingen blijkt dat er naast regulering tegelijkertijd een 'zorgvuldige arts inzake levensbeëindigend handelen' werd geconstrueerd; namelijk de arts die zich aan de zorgvuldigheidseisen houdt. Alleen die arts zou op het vertrouwen van de maatschappij kunnen rekenen. ${ }^{37}$

Uit het twistpunt over de regulering van levensbeëindigend handelen komt naar voren dat er verschillen van mening bestaan over het vertrouwen dat men in de medische professie heeft. Sommigen pleiten voor wetgeving, onder meer omdat bij ontwikkeling via jurisprudentie artsen (en ook patiënten en de rechter) niet precies zouden weten waar ze aan toe zijn. Anderen daarentegen hadden groot vertrouwen in het handelen van de medische professie en achtten de medisch professionele standaard (een invulling van de zorgvuldigheidseisen in de prakrijk) voldoende voor een goed functionerende euthanasiepraktijk. Dit vertrouwen was op dat moment kennelijk onvoldoende, want er werd verder gebouwd aan een juridisch explicieter verankerd netwerk rond de zorgvuldigheidseisen. Niet in de laatste plaats omdat hierbij een centrale plaats aan de zorgvuldigheidseisen was toegekend, die al als een knooppunt of een feit werden beschouwd. Dit in tegenstelling tot de tweede optie waarin de zorgvuldigheidseisen als vanzelfsprekend onderdeel van de medisch-professionele standaard werden beschouwd en als zodanig geen zelfstandige juridische functie aan ze werd toegekend. Bovendien werd er bij de eerste optie veel werk verzet om te zorgen dat er expliciet vertrouwen was in de beroepsgroep; het volgen van de zorgvuldigheidseisen werd hiervoor als een betrouwbaar instrument beschouwd. Met andere woorden, vertrouwen in de medische professie is bij de eerste optie iets waaraan gewerkt moet worden, terwijl de tweede optie ervan uit gaat dat dit vertrouwen er al (sinds lange tijd) is.

Een min of meer uitgekristalliseerd normatief kader (euthanasie is geoorloofd mits aan een aantal voorwaarden is voldaan) bood aan artsen geen garantie om euthanasie of hulp bij zelfdoding zonder juridische consequenties toe te kunnen passen. Aan de hand van meerdere schakels is veel werk gemaakt van het opbouwen van vertrouwen in artsen. In de onderhandelingen hierover werd een bepaalde orde gecreëerd, waarin ethische en juridische overwegingen een rol spelen. Zo moest bepaald worden wat de rol was van het recht, de rechter, de medische ethiek en de medische praktijk bij het vinden van een juridische grondslag voor het ongestraft toe kunnen passen van euthanasie en hulp bij zelfdoding. Het algemene idee dat er eerst een normatieve orde moet zijn alvorens een regulatieve orde kan worden gevormd bleek niet op te gaan, simpelweg 
ondlat er onder andere geen consensus was over de richtlijnen in de medische (rhiek. De normen, richrlijnen en regels ontwikkelden zich tegelijkertijd en in samenhang mer het debat over de medische prakrijk rond levensbeëindigend handelen. De zelfbeschikking van de patiënt als norm werd ondergeschikt gemaakt aan het gewetensconflict van de arts, omdar het beroep op het ontbreken van de materiële wederrechtelijkheid werd afgewezen als grondslag, ten koste van het beroep op de noodtoestand. Achteraf is dus zichtbaar dat het netwerk werd opgebouwd rond de (behandelend) arts. In juridisch opzicht was euthanasie kennelijk geen probleem van de patiënt, maar van de arts; het ging om zijn noodtoestand. Daarbij werd de invulling van die noodtoestand opengelaten; deze was afhankelijk van de stand van zaken in de medische ethiek.

\section{Nieuwe koppelingen in het netwerk rond levensbeëindigend handelen}

\section{Een uniforme meldingsprocedure voor medische beslissingen rond het levenseinde}

Begin jaren negentig waren euthanasie en hulp bij zelfdoding ingebed in een tamelijk stabiel normatief en regulatief netwerk. Er bestonden weliswaar nog enkele vraagtekens over de hardheid van sommige vereisten, zoals de vraag of er nu wel of geen sprake zou moeten zijn van een stervensfase, maar in hoofdlijnen was het kader bekend. In verschillende boeken over ethiek en recht in de gezondheidszorg werd dit kader dan ook bevestigd en worden de zorgvuldigheidseisen als een voldongen feit beschouwd (De Beaufort \& Dupuis 1988; De Graaf 1990; Kalkman-Bogerd 1990). Het concept van de zorgvuldigheidseisen was met de uitvoeringspraktijk van levensbeëindigend handelen verbonden geraakt en het roer kon wat dat betreft niet meer zo gemakkelijk om. Mede vanwege de politieke impasse eind jaren tachtig was het vraagstuk (nog) niet wettelijk geregeld. De opgestelde set van zorgvuldigheidseisen fungeerde als richtsnoer voor het vervolgingsbeleid, maar was niet als een uniforme regeling op te vatten. Op her moment dat er pogingen werden ondernomen om inderdaad een regeling tot stand te brengen bracht dit de nodige reacties teweeg. Ondanks het feit dat er geen consensus was over een uniforme regeling ging de regulering wel door. Om de tot stand gekomen regeling stabiel te blijven houden, moest het netwerk echter wel worden onderhouden. Als er nieuwe elementen aan het netwerk worden toegevoegd, werden dus ook de zorgvuldigheidseisen opnieuw tegen het licht gehouden. Dat betekent dat de uitbreiding van het netwerk ook ten aanzien van de zorgvuldigheidseisen het nodige werk vereiste. Deze paragraaf gaat in op de manier waarop tot halverwege de jaren negentig het netwerk rond euthanasie en hulp bij zelfdoding werd uitgebreid en welke consequenties (en ook implicaties) dit had. 
$\mathrm{Na}$ de val van het tweede kabinet-Lubbers eind jaren tachtig was in het nieuwe regeerakkoord besloten om wetgeving over euthanasie uit te stellen tot er meer inzicht zou zijn verkregen in de omvang en de aard van de euthanasiepraktijk. Dit gebeurde door een onderzoekscommissie, de commissie Remmelink, in het leven te roepen die (kwantitatieve) uitspraken moest gaan doen over de medische praktijk van euthanasie. ${ }^{38} \mathrm{Op}$ die manier kreeg ook de uitvoeringspraktijk van euthanasie een plaats in het netwerk. Het was de bedoeling dat een groot aantal huisartsen, verpleeghuisartsen en specialisten bij het onderzoek betrokken zouden worden. Volgens het voor-wat-hoort-wat principe stelde de KNMG aan de medewerking van artsen bij dit onderzoek duidelijke voorwaarden, onder andere dat er éénduidig beleid inzake de meldingsprocedure voor euthanasie zou komen (KNMG 1990). Ze stelde voor dat een arts die euthanasie of hulp bij zelfdoding (niet levensbeëindiging zonder verzoek) toepaste dit zou melden bij de gemeentelijk lijkschouwer. De gemeentelijk lijkschouwer rapporteerde dan aan de officier van Justitie. In de gevallen waarin de arts had gehandeld conform de geldende zorgvuldigheidseisen, zou de officier van justitie in het algemeen besluiten de arts niet te vervolgen. De KNMG bezette een dusdanige positie in het veld, dat men niet om het standpunt van deze organisarie heen kon, dus de genoemde procedure werd officieel vastgesteld en erkend door de Minister van Justitie. Hiermee leek er een eind te zijn gekomen aan een 'jarenlange onduidelijkheid in deze kwestie' (p. 1303). Kortom, hier vond wederom een translatie plaars: wat eerst een concept was, werd vervolgens vertaald naar aandachtspunten in een vragenlijst voor de praktijk. De meldingsprocedure, die op I november 1990 inging gold voor zowel euthanasie als hulp bij zelfdoding en betekende dat artsen op vrijwillige basis verslag uitbrachten aan de gemeentelijk lijkschouwer (KNMG I99I). ${ }^{39}$

In haar rapport introduceerde de commissie Remmelink een nieuw begrip: 'medische beslissingen rond het levenseinde'. Zij had zich bewust niet beperkt tot de praktijk van euthanasie en hulp bij zelfdoding. omdat het volgens de onderzoekers van groot belang was 'een beeld te kunnen schetsen van de plaats van euthanasie binnen het hele scala van medische beslissingssituaties rond het levenseinde' (Remmelink 199I: 3). Bovendien stelde ze dat er glijdende overgangen bestonden tussen de verschillende soorten beslissingen rond het levenseinde (p. 3r). Dat betekende dat met het rapport van de Commissie Remmelink, alle vormen van levensbeëindigend handelen in het netwerk waren opgenomen. Het tot dan toe gehanteerde onderscheid tussen euthanasie en hulp bij zelfdoding enerzijds en levensbeëindiging zónder verzoek anderzijds werd hiermee opgeschort. Dit werd bezegeld in de Wet op de lijkbezorging. Nieuwe koppelingen in het netwerk betekenen dus dat wat in het debat ter discussie verandert. In het netwerk wordt het object van discussie geconstitueerd. Aanvankelijk ging het om een brede categorie van vragen rond het levenseinde, na een 
scherpe afbakening ging het vervolgens om levensbeëindiging op verzoek en met de nieuwe koppelingen was ook levensbeëindiging zonder verzoek in het nerwerk opgenomen. Zowel ethici als juristen hebben hun aandeel geleverd in deze groei van het netwerk waardoor de nieuwe koppelingen tot stand zijn gekomen en daarmee het object van discussie aan verandering onderhevig is.

Het onderzoek van de commissie Remmelink bracht in grote lijnen - voor de politiek - geruststellend cijfermateriaal op tafel. ${ }^{+\circ}$ Het onderzoek wekte voldoende vertrouwen bij de regering, want twee maanden later kwam de regering met een standpunt inzake 'medische beslissingen rond het levenseinde' en een conceptvoorstel voor een nieuwe wet. ${ }^{41}$ Het voorstel luidde om de Wet op de lijkbezorging te veranderen." Er werd, wederom, een nieuw element gekoppeld aan her netwerk rond de regeling van euthanasie. In tegenstelling tot de eerste meldingsprocedure, die een vrijwillig karakter had, werden artsen door dit voorstel min of meer gedwongen om verantwoording af te leggen. Met de verandering van de Wet op de Lijkbezorging moest het mogelijk worden om bij Algemene Maarregel van Bestuur regels vast te stellen met betrekking tot levensbeëindigend handelen op verzoek én zonder verzoek (Kamer 199I-1992: 8). Het is duidelijk dat de regering meeging in de nieuwe definitie zoals geïntroduceerd door de Commissie Remmelink. Het ging niet meer alleen om de regulering van euthanasie en hulp bij zelfdoding, maar om regulering van meerdere vormen van levensbeëindigend handelen.

Volgens dit regeringsvoorstel bleef de strafbaarheid van een arts, die volgens de zorgvuldigheidseisen handelde, gehandhaafd. Maar anders dan in eerdere voorstellen werden de zorgvuldigheidseisen niet meer wettelijk geregeld. De arts moest zich nu niet meer alleen op de zorgvuldigheidseisen richten, maar ook op de nieuwe lijst met aandachtspunten. Deze aandachtspunten waren een uitwerking van de zorgvuldigheidseisen en vormden de leidraad voor her invullen van een niet-natuurlijke dood verklaring: het zogenoemde modelformulier. Met behulp van deze lijst werd getracht her melden van levensbeëindiging door een arts te standaardiseren. Een arts kon in geval van 'medische beslissingen rond het levenseinde' niet meer om deze aandachtspunten heen. Dat betekende tevens dat het oordeel van een arts 'noodgedwongen' middels het afvinken van de aandachtspunten vorm had gekregen. Deze fungeerden als het gematerialiseerde vertrouwen dat in de medische professie was gesteld en tegelijkertijd ook als controle.

Het wetsvoorstel van de regering stuitte op nogal wat weerstand (Gezondheidsraad 1992; Leenen 1992a, 1992b; Wöretshofer 1992). Deze weerstand gaf aan dat het voorstel grenzen verlegde en dit ging sommigen te snel of te ver. Zo pleitte de Beraadgroep Gezondheidsethiek en Gezondheidsrecht van de Gezondheidsraad voor een eigen toetsingskader voor euthanasie en hulp bij zelfdoding enerzijds en levensbeëindiging zonder verzoek anderzijds. Zij gaf 
(in een uit eigen beweging opgesteld advies) kritiek op het opheffen van het onderscheid tussen deze vormen van levensbeëindiging. Leenen, ook lid van de Beraadgroep Gezondheidsethiek en Gezondheidsrecht, maakte zijn standpunt nog eens duidelijk in een tweetal artikelen. Hij meende dat de regering met dit voorstel haar verantwoordelijkheid aan het afschuiven was (Leenen 1992b: 48). Leenen vroeg zich dan ook ernstig af of artsen wel levensbeëindiging zónder verzoek zouden gaan melden, omdat de stand van de jurisprudentie geen algemene aanvaarding van actieve levensbeëindiging zónder verzoek inhield (Leenen 1992a: 6). Hij vond dat de regering voorbijging aan de hoeveelheid moeite die het had gekost om levensbeëindiging op verzoek op een 'goede wijze in de discussie te brengen' door daar nu de levensbeëindiging zónder verzoek op één lijn naast te zetten. Een soortgelijke kritiek werd ook door de jurist Wöretshofer geuit. Hij meende dat met de meldingsprocedure op een oneigenlijke manier twee doelstellingen aan elkaar werden geknoopt: controle op levensbeëindigend handelen op verzoek en het achterhalen van criteria voor levensbeëindiging zónder verzoek (Wöretshofer 1992: 789). Naar de reacties af te meten is het niet mogelijk om de uitgekristalliseerde zorgvuldigheidseisen voor euthanasie en hulp bij zelfdoding in één klap te verplaatsen en te vertalen naar andere vormen van levensbeëindigend handelen.

De verschillende gebundelde krachten in het tot stand gekomen netwerk zorgden ervoor dat er geen consensus nodig was om tot een besluit te komen. De Eerste Kamer besloot namelijk tot wijziging van (art. Io van) de Wet op de Lijkbezorging. Op grond hiervan kwam in juni 1994 een Algemene Maatregel van Bestuur tot stand, waardoor de bestaande meldingsprocedure wettelijk verankerd werd voor: euthanasie, hulp bij zelfdoding en levensbeëindiging zonder verzoek (in lijn met het advies van de Commissie Remmelink). Dit betekende echter dat euthanasie nog steeds strafbaar was, want de voorwaarden waaronder euthanasie straffeloos kon plaatsvinden waren niet wettelijk verankerd; ze zouden nog steeds moeten worden ontleend aan de jurisprudentie en aan de interpretatie daarvan door her Openbaar Ministerie (Dillmann 1994). Deze regeling was het resultaat van jarenlange pogingen tot het codificeren en standaardiseren van (vormen) van levensbeëindigend handelen in de medische praktijk te komen.

\section{De elasticiteit van de zorgvuldigheidseisen}

Parallel aan bovenstaande groei van het netwerk en de gelijktijdige veranderingen in het onderwerp van discussie was er ook sprake van een verandering in dc zorgvuldigheidseisen. Als de psychiater Chabot in 1993 hulp bij zelfdoding heeft verleend aan een vrouw die daarom had verzocht op grond van psychisch lijden, is dat de eerste keer dat psychisch lijden als vorm van 'ondraaglijk en uitzichtloos' lijden in de rechtspraak ter discussie staat. 'Tot dan toe had de vereiste valn 
'ondraaglijk en uitzichtooos lijden' altijd een somatische invulling gehad. ${ }^{43}$ In dit geval ging het om een vrouw, die na een serie (psychische) traumatische ervaringen een doodswens had. Chabot kwam na meerdere gesprekken tot de conclusie dat er in haar geval geen sprake was van een psychische ziekte, maar dat ze aan een stoornis leed in het kader van een gecompliceerd rouwproces. Psychiatrische behandeling zou mogelijk zijn, maar mer weinig kans op succes. ${ }^{44}$ De rechrbank van Assen en het hof van Leeuwarden waren van mening dat in dit specifieke geval het verweer van de noodtoestand gegrond was. Dit werd in het arrest van de Hoge raad in juni 1994 bevestigd, met die kanttekening dat in geval van psychisch lijden werd geëist dat de consulterende arts de patiënt ook daadwerkelijk gezien moest hebben (dit was bij de zaak Chabot niét het geval geweest). Deze uitbreiding van het netwerk betekende een translatie van de zorgvuldigheidseisen. De zorgvuldigheidseisen werden nu ook expliciet van toepassing op psychisch lijden. Dit betekende een verandering of specificatie van de consultatieeis (de arts moet de patiënt gezien hebben) en tevens een nieuwe groep artsen, namelijk psychiaters, die op een specifieke manier aan het netwerk werden gekoppeld. Deze ontwikkelingen vonden tegelijkertijd plaats; het lijden werd 'opgerekt' en de consultatie-eis aangescherpt. Tot dan toe was de consultatie-eis voor euthanasie niet nader gespecificeerd geweest. Tegelijkerrijd was met de zaak Chabot het idee verworpen dat een psychiatrische patiënt geen vrijwillig verzoek om hulp bij zelfdoding zou kunnen doen. ${ }^{45}$ Bovendien was de eis van ondraaglijk en uitzichtloos lijden nu ook bij psychisch lijden toegepast.

Deze verruiming van de normering vormde de aanleiding voor kritische reacties op het arrest. Sommigen meenden hierin een 'verontrustende wending van de Nederlandse euthanasie-praktijk' te zien (Achterhuis \& Goud et al. 1995). Zo uitte de jurist Schalken kritiek op het gebruik van de 'noodtoestand' door de Hoge Raad in het Chabot-arrest. 'De noodtoestand was aanvankelijk in de rechtspraak als oplossing voor speciale gevallen gedacht. Maar door de wijze waarop de Hoge Raad de noodtoestand in kwesties van euthanasie en hulp bij zelfdoding heeft geconstrueerd, is de uitzondering tot algemene acceptatie verbreed' (Schalken 1995: 79). Volgens Schalken moest het recht niet worden ingericht als een model voor uitzonderingssituaties. Hij was van mening dat het recht niet voldoende kritisch meer was bij haar taak om de medische macht te controleren.

Een tweede rechtszaak die spanningen opleverde binnen het netwerk was de zaak Prins. ${ }^{46}$ Daarin ging het om actieve levensbeëindiging bij een ernstig gehandicapte pasgeborene. De gynaecoloog Prins beëindigde begin 1993 het leven van een gehandicapte pasgeborene, die aan ernstige en moeilijk te bestrijden pijn leed. Hoewel de meldingsprocedure op dat moment nog niet voor deze vorm van levensbeëindigend handelen gold, gaf Prins de zaak wel aan de gemeentelijk lijkschouwer door. Ook in dit geval honoreerde de rechtbank het 
beroep van de arts op de noodtoestand, onder bepaalde voorwaarden. Deze voorwaarden kwamen overeen met de bekende zorgvuldigheidseisen, waarbij in dit geval werd gesteld dat de levensbeëindiging 'op uitdrukkelijk, herhaald en consistent verlangen van de betrokken ouder(s) als wettelijke vertegenwoordiger(s) van de pasgeborenen' zou moeten plaatsvinden. Zoals na de zaak-Chabot het lijden en de consultatie-eis werden aangepast, werd na de zaak Prins de eis van het verzoek enigszins aangepast.

In een reactie op dit vonnis stelde Leenen ten eerste dat, hoewel hij zich kon vinden in de uitkomst van het vonnis, de rechtbank onvoldoende onderscheid had gemaakt tussen euthanasie en medisch zinloos handelen. Volgens hem was 'er geen twijfel over dat in de zaak-Prins medisch handelen bij de baby zinloos was. De rechtbank gaat daar ook van uit, maar begeeft zich vervolgens niettemin in criteria die in het algemeen bij euthanasie worden gebruikt. Dat is onnodig en verwarrend. (...) Het is jammer dat de rechtbank deze weg heeft gevolgd. Daardoor zijn in het vonnis medisch zinloos handelen en euthanasie door elkaar gaan lopen' (Leenen 1995: 85I). Ten tweede vond Leenen dat de rechtbank ook onvoldoende onderscheid had gemaakt tussen euthanasie en levensbeëindiging zónder verzoek. 'Het verzoek moet van de betrokkene zelf komen en kan niet door een wettelijke vertegenwoordiger of plaatsvervanger worden gedaan. Daarover is in de literatuur vrijwel overeenstemming' (p. 852). I.eenen gaf hier, net als in zijn reactie op het regeringsvoorstel waarin de regulering van euthanasie werd uitgebreid naar medische beslissingen rond het levenseinde, aan dat er wat hem betreft grenzen overschreden werden. Hij vond niet dat de voor euthanasie (en hulp bij zelfdoding) geformuleerde zorgvuldigheidseisen moesten en konden worden toegepast op (acrieve) levensbeëindiging bij ernstig gehandicapte baby's. Kortom, Leenen verzette zich tegen het uitbreiden van het (normatieve en regulatieve) netwerk rond euthanasie naar medische beslissingen rond het levenseinde. Niettemin was met de zaak Chabot en de zaak Prins een begin gemaakt met jurisprudentie over levensbeëindiging bij de categorie patiënten zoals die in de rapporten van de Commissie Aanvaardbaarheid L.evensbeëindigend handelen (CAL) van de KNMG aan de orde zijn gekomen. ${ }^{47}$

Met her beschrijven van nieuwe koppelingen in het netwerk rond levensbeëindigend handelen geschetst is bovendien aangegeven welke verschuivingen in de te reguleren praktijk en de te hanteren normen dit heeft opgeleverd. Er werd aan de eisen van de medische professie voor de meldingsprocedure voor euthanasie tegemoet gekomen toen men de medische praktijk het netwerk binnen wilde brengen; er kwam een meldingsprocedure voor het toepassen van euthanasie tot stand. Deze meldingsprocedure werd in een wettelijke maatregel omgezet die voor álle vormen van levensbeëindigend handelen gold. Deze tweede uitbreiding is niet zonder de nodige weerstand tot stand gekomen. Juist de dan gevormde infrastructuur maakte het mogelijk dat er knopen werden 
doorgehakt zonder dat er van een algehele consensus sprake was. De normering van euthanasie en hulp bij zelfdoding veranderde door uitspraken in de jurisprudentie, over gevallen die aanvankelijk niet binnen de tot stand gekomen orde pasten. Toen ook psychiaters en kinderartsen in het netwerk opgenomen moesten worden, ging dat met een wijziging in de normering gepaard.

\section{Knooppunten en netwerken}

Hoe zijn normering en regulering - in de vorm van de inmiddels wettelijk vastgelegde zorgvuldigheidseisen - rond levensbeëindigend handelen tot stand gekomen? Om deze vraag te beantwoorden is gebruik gemaakt van een theoretisch kader uit het wetenschapsonderzoek. Door uit te gaan van een netwerktheorie over het stand komen van normen en regels is het mogelijk geweest om het netwerk van de zorgvuldigheidseisen in aanbouw te onderzoeken. Het wetenschapsonderzoek is bij uitstek geschikt om inzicht te krijgen in het werk dat is verricht om tot normering en regulering te komen (in plaats van te onderzoeken hoe het eindresultaat eruit ziet). Daarbij staan de verschillende koppelingen die tot stand komen in een netwerk centraal. Normering en regulering zijn pas mogelijk binnen een (stabiel) netwerk van diverse relaties, ná het vormen van een aantal knooppunten. De ingang van het wetenschapsonderzoek bood de mogelijkheid om te onderzoeken hoe recht en ethiek zich tot elkaar verhouden tijdens het tot stand komen van normering en regulering. Het idee dat er een vaste verhouding zou bestaan tussen recht en ethiek werd geproblematiseerd. Beide zijn juist als onderdeel van de ontwikkelingen beschouwd en niet als kennis die probleemloos (op instrumentele wijze) ingezet kan worden.

De nieuwe kwestie van vragen rond her levenseinde kon begin jaren zeventig niet in een bestaande juridische en of normatieve orde geplaatst worden. De uiteindelijke zorgvuldigheidseisen werden niet op geleide van een vooraf bepaalde stand van zaken binnen de ethiek of het recht die determinerend zou zijn geconstrueerd, maar zijn het resultaat van de manier waarop rond levensbeëindigend handelen een netwerk is ontstaan. Normen en regels komen niet in een vacuüm tot stand, maar ontwikkelen zich tegelijkertijd en in samenhang met een bepaalde uitvoeringspraktijk c.q. de medische praktijk van levensbeëindigend handelen. Normering en regulering komen tot stand via een heterogene orde: van een voorstel voor een (normatieve) definitie voor eurhanasie, uitspraken in rechtszaken tot diverse adviezen in verschillende gremia. Het idee dat een (nog nader te bepalen) vorm van euthanasie, mits aan bepaalde voorwaarden was voldaan, geoorloofd zou moeten zijn won steeds meer aan overtuigingskracht. De genoemde voorwaarden kregen telkens een andere invulling, afhankelijk van de plaats en het doel (een rechtszaak over euthanasie, een 
rechtszaak over hulp bij zelfdoding, advies van een overheidsorganisatie of van een belangenorganisatie voor artsen) waarvoor ze waren geformuleerd. Toch werd de ruimte om invulling aan deze voorwaarden te geven op een gegeven moment ingeperkt, doordat er een koppeling tussen het toepassen van euthanasie en de medische professie (en daarmee aan medische routines zoals: consultatie en de toegang en het gebruik van geneesmiddelen) tot stand kwam. ${ }^{48}$

Als ook verpleegkundigen, pastores of bijvoorbeeld leden van de NVVE in aanmerking zouden zijn gekomen voor het geoorloofd toepassen van euthanasie en hulp bij zelfdoding zouden de uiteindelijke normering en regulering er vermoedelijk anders hebben uitgezien. De zorgvuldigheidseisen vertrekken nu voor een deel vanuit de veronderstelling dat degene die een verzoek om euthanasie moet beoordelen over de nodige medische kennis en expertise beschikt. Het vereiste verzoek tot euthanasie is ingebed in een medische context en staat als zodanig dus niet op zichzelf; een verzoek of een sterke wens alleen is niet voldoende. ${ }^{49} \mathrm{Als}$ ook andere deskundigen gelegitimeerd zouden zijn om een dergelijk verzoek te beoordelen had bijvoorbeeld het toetsen van de duurzaamheid van het verzoek door een psycholoog wellicht centraal gestaan. Vanuit het beschreven netwerkperspectief is nu ook het feit dat de toepassing van bijvoorbeeld euthanasie alleen aan artsen is voorbehouden begrijpelijk geworden. Artsen nemen, voorlopig en pas sinds kort, een centrale positie in het netwerk in. Het zal geen eenvoudige zaak zijn om deze positie uit te breiden of te vervangen door andere deskundigen. ${ }^{\circ}$ De huidige positie van de arts bij de normering en regulering van euthanasie is namelijk ingebed in een netwerk van diverse elementen zoals: de status van de medische professie, de legitimiteit van het ongestraft kunnen toepassen van euthanasie, de opgebouwde jurisprudentie en de zorgvuldigheidseisen.

De stabilisering van de koppeling tussen voorwaarden voor het toepassen van euthanasie en hulp bij zelfdoding en de medische professie betekende halverwege de jaren tachtig niet dat een arts straffeloos deze hulp kon verlenen. Er was nog geen sprake van een gereguleerde praktijk. Er waren ruwweg drie mogelijke oplossingen voor dit probleem. Moest het vraagstuk via jurisprudentie, wetgeving of juist binnen de medische professie met haar eigen professionele standaard worden opgelost? Op voorhand was niet duidelijk welke rol recht en ethiek bij deze drie opties zouden spelen. In de onderhandelingen hierover waren recht en ethiek juist inzet van discussie; de rollen kregen pas tijdens het vormen van het netwerk hun beslag. Op voorhand was niet één van de drie genoemde opties meer of beter geschikt dan de andere. De manier waarop her netwerk werd opgebouwd bleek uiteindelijk doorslaggevend. Het concept van de zorgvuldigheidseisen was inmiddels zo 'hard' geworden dat het bijna onmogelijk werd om een regeling voor euthanasic tot stand te brengen zonder dar daarin aan de zorgvuldigheidseisen een plaats werd gegeven. De zorgvuldig- 
heidseisen waren, hoewel ze nog steeds in beweging zijn, een verplicht station geworden voor de uiteindelijk tot stand gekomen wettelijke regulering van euthanasie. Niettemin moest er nog steeds veel werk verzet worden voordat er inderdaad sprake was van een wettelijke regeling voor euthanasie en hulp bij zelfdoding.

Er werden eerst nog - ondanks enige weerstand hiertegen - nieuwe koppelingen gemaakt in het netwerk. De tot stand gekomen normering en regulering veranderde telkens wanneer nieuwe elementen aan het netwerk werden gehangen. Ten eerste moesten er concessies worden gedaan om de medewerking van artsen te verkrijgen voor een grootschalig empirisch onderzoek: er werd een meldingsprocedure afgedwongen. Ten tweede werd het netwerk uitgebreid van euthanasie en hulp bij zelfdoding naar 'medische beslissingen rond het levenseinde'. Het netwerk werd uitgebreid en gesplitst, dit betekende dat de geformuleerde zorgvuldigheidseisen nu ook op levensbeëindiging zonder verzoek betrekking hadden. ${ }^{51}$ Ten derde werden ook de psychiaters en kinderartsen in het netwerk opgenomen. Dit had tot gevolg dat ook psychisch lijden en levensbeëindiging bij pasgeborenen bij de normering en regulering betrokken werden. Ondanks de niet geringe weerstand hiertegen bleek het toch mogelijk om de normering en regulering uit te breiden. Dit kan alleen verklaard worden door het feit dat de inmiddels opgebouwde infrastructuur (zorgvuldigheidseisen, jurisprudentie, overheidsbemoeienis) al soepel draaiende was. Er hoefde geen algehele consensus te zijn om tot uitbreiding te komen; normering en regulering komen tot stand op de diverse schijven van het netwerk.

Kortom, aanvankelijk was er geen zicht op de huidige, wettelijk vastgelegde, zorgvuldigheidseisen. Op basis van argumenten pro en contra diverse voorstellen rond euthanasie werd een zekere orde opgebouwd. In deze orde werd een aantal 'verplichte stations' gevormd, zoals: euthanasie mag alleen door een arts worden toegepast, op voorwaarde dat de zorgvuldigheidseisen in acht zijn genomen. Rond deze twee harde feiten: de arts en de zorgvuldigheidseisen, werd ook een materieel netwerk gespannen. Materiële zaken, zoals de meldingsprocedure en de formulieren met de aandachtspunten kregen de functie van een soort protocol of standaard voor het toepassen van euthanasie. In dit netwerk was er geen vooraf bepaalde functie of positie van recht en ethiek. De relatie tussen recht en ethiek bij normering en regulering werd telkens opnieuw bepaald, afhankelijk van de wijze waarop in het netwerk knooppunten tot stand zijn gekomen.

In het netwerk rond de zorgvuldigheidseisen is de rol van recht en ethiek niet gegeven. Dit kan nog eens worden geïllustreerd aan de praktijk van de regionale toetsingscommissies die inmiddels ook onderdeel vormen van het materiële netwerk rond de zorgvuldigheidseisen. ${ }^{12}$ Er blijkt speelruimte te zijn in de manier waarop door de toetsingscommissies, bestaande uit een jurist, een ethicus en een arts, met de zorgvuldigheidseisen wordt omgegaan. Het jaarverslag 
van de regionale toetsingscommissies maakt dit inzichtelijk. Zo blijkt de uitkomst van de procedure om gemelde gevallen van euthanasie en hulp bij zelfdoding, aan de hand van de zorgvuldigheidseisen te toetsen, (nog) geen hard gegeven. In enkele gevallen was er volgens de zorgvuldigheidseisen zoals toegepast door de toetsingscommissie sprake van onzorgvuldig handelen, maar besloot het College van procureurs generaal toch om niet tor vervolging over te gaan (Jaarverslag 200I). In de praktijk is er kennelijk speelruimte voor de manier waarop met de zorgvuldigheidseisen wordt omgegaan. Uit wetenschapsonderzoek naar de rol van protocollen in de medische praktijk kwam naar voren dat protocollen niet alleen praktijken standaardiseren, maar dat praktijken tegelijkertijd ook veranderen door de introductie van protocollen (Berg 1998). De zorgvuldigheidseisen lijken een hard gegeven, maar in de praktijk is de uitkomst mede afhankelijk van de manier waarop ze worden gehanteerd. Normen en regels liggen niet helemaal vast. De praktijkverslagen van gemelde gevallen van euthanasie bij de regionale toetsingscommissies geven bijvoorbeeld een gevarieerder beeld dan in de literatuur over eurhanasie wordt verondersteld (Widdershoven 1999). Niet alleen autonomie maar ook barmhartigheid blijkt als motivering voor hun beslissing door artsen te worden gegeven. Dit betekent dat er voor ethici en juristen in de regionale toetsingscommissies door middel van feedback ruimte is om, op basis van ervaringen uit de praktijk en in contact met artsen, toekomstige beslissingen te beïnvloeden. 



\section{SLOTBESCHOUWING}

Lopen gezondheidsethiek en gezondheidsrecht in medisch-ethische debatten onvermijdelijk achter de ontwikkelingen aan? Een veel gehoorde klacht over ethiek en recht is dat ze te traag of niet kritisch genoeg reageren op de actualiteiten. De adviezen die binnen deze twee disciplines worden ontwikkeld zouden soms als mosterd na de maaltijd komen. Bovendien is volgens sommigen de ethiek als toegepaste discipline teveel naar het recht omgebogen en heeft ze zich een juridische denkstijl aangemeten.' Daardoor zou het onderscheidend vermogen tussen de twee vakgebieden zijn afgenomen. In onderhavige studie is vanuit een specifiek theoretisch perspectief onderzoek gedaan naar de ontwikkeling van en verhouding tussen de disciplines gezondheidsethiek en gezondheidsrecht. Aan de hand van drie verschillende invalshoeken is getracht diverse aspecten van beide disciplines in 'actie' - namelijk in discussies over levensbeëindigend handelen - tc belichten."

Het gehanteerde theoretisch perspectief gaat uit van de dynamiek tussen de cognitieve kenmerken en de sociale context van disciplines. De ontwikkeling van een discipline wordt in gangbare disciplinegeschiedenissen veelal afzonderlijk van andere disciplines bestudeerd. Daarentegen ligt in de hier gehanteerde theorerische kaders de nadruk op de samenhang tussen ontwikkeling van en relatie tussen de disciplines gezondheidsrecht en gezondheidsethiek. De disciplines zijn met elkaar en met maatschappelijke ontwikkelingen verweven. De drie empirische hoofdstukken hebben laten zien dat dit perspectief vruchtbaar is. De analyses hebben de inspanning zichtbaar gemaakt die met de ontwikkeling van de vakgebieden gepaard is gegaan.

In de volgende paragrafen wordt niet alleen de vraag uitgewerkt wat de studie van de ontwikkeling van beide disciplines in termen van jurisdictie, denkstijlen en netwerken, de drie verschillende theoretische perspectieven uit hoofdstuk drie, vier en vijf, heeft opgeleverd voor de vraagstelling van het onderzoek. Ook wordt nagegaan wat de bredere toepasbaarheid van dit perspectief is. De tweede paragraaf zet de opbrengst van de gecombineerde disciplinegeschiedenis af tegen elementen uit een standaard disciplinegeschiedenis en gaat tevens in op de manier waarop de onderlinge afhankelijkheid tussen recht en ethiek gevolgen heeft voor het professionele debat over de relatie tussen de twee disciplines. In de derde paragraaf wordt een ruimere toepassing van de interactie 
tussen recht en ethiek in de context van levensbeëindigend handelen onderzocht. Deze paragraaf laat zien wat de bevindingen van het meervoudige theoretische perspectief zijn voor enkele recente ontwikkelingen naar aanleiding van het debat over euthanasie. Aan de hand van een voorbeeld van een 'klaarmet-leven-situatie', de zaak Brongersma, wordt de relevantie van deze heuristiek nader verkend. In de vierde en laatste paragraaf wordt ingegaan op de vraag of ethiek en recht achter de feiten aanlopen, zoals soms kritisch wordt opgemerkr. Veranderingen in de samenleving zouden met een vertraagd effect tot veranderingen in de ethiek en het recht leiden. Dit onderzoek heeft laten zien dat er niet alleen in een laat stadium, in de adviesfase, een rol voor ethiek en recht is weggelegd. De wijze waarop professionele verantwoordelijkheid en maatschappelijke controle bij euthanasie zijn geregeld is het resultaat van een bepaald begrippenkader waar ethici en juristen hard aan mee hebben gewerkr. Het boek besluit met een korte discussie over de mogelijkheden en beperkingen van ethiek en recht inzake morele vraagstukken in de gezondheidszorg.

\section{Gezondheidsrecht en gezondheidsethiek: interactie}

Her debat over levensbeëindigend handelen is in dit onderzoek als één van de arena's beschouwd waar ethici en juristen hard hebben gewerkt aan de ontwikkeling van hun discipline. De verschillende analyses in de empirische hoofdstukken laten zien hoé de interactie van de beide disciplines met elkaar en in relatie tot het debat over levensbeëindigend handelen eruit ziet. Het onderwerp van debat verandert en maakt in grote lijnen een beweging van onafgebakende vragen rond het levenseinde, naar een scherpe definitie voor euthanasie en vervolgens een ruimer geformuleerde problematiek aangeduid als medische beslissingen rond het levenseinde. De zeggenschaps-analysevan de definitie van eurhanasie laat zien dat de aard van de problematiek rond levensbeëindigend handelen niet op voorhand vast lag. De zeggenschap hierover wisselt. Dat wat als (de kern van) het probleem werd gezien, kristalliseerde zich uit omdat bepaalde argumentaties overtuigend werden gemaakt. Artsen en juristen claimden aanvankelijk dat het probleem samenhing met het ontwikkelen van nieuwe verantwoordelijkheden voor de arts. Sommige ethici vroegen aandacht voor stervensbegeleiding als ingang voor een oplossing in de discussie over levensbeëindigend handelen. Op de gezamenlijke agenda van ethici en juristen stond de positie van de patiënt bij vragen rond het levenseinde. Het idee was de positie van de patiënt te versterken om op die manier tegenwicht te bieden aan de toenemende medische macht. Daar werd echter wel verschillend over gedacht.

De inbreng van artsen, juristen en ethici stond niet van te voren vast, maar veranderde als er bijvoorbeeld een nieuw probleem werd geïntroduceerd in her 
debat. Dit blijkt uit de discussie over het probleem van levensbeëindiging bij wilsonbekwamen, begin jaren negentig. De coalitie tussen artsen en juristen veranderde in een coalitie tussen artsen en ethici. Het argument van zelfbeschikking en autonomie van de patiënt, dat eerst als een oplossing voor het probleem van de medische macht was ingezer, bleek in de nieuwe discussie een knelpunt te zijn. Deze nieuwe discussie werd vooral onder ethici en artsen gevoerd. ${ }^{3}$ Voor juristen was het argument van zelfbeschikking te belangrijk om het tussen haakjes te kunnen zetten. Er ontstond een nieuwe coalitie met andere argumenten, zoals discussies over de kwaliteit van leven. Het argument van barmhartigheid werd bijvoorbeeld opnieuw verkend, onder andere door de ethicus Kuitert. Daaruit blijkt dat het geenszins vanzelfsprekend is dat zelfbeschikking en autonomie dé oplossing voor het vraagstuk van levensbeëindigend handelen zijn geworden. Een type ethische argumenten dat in de jaren zeventig of tachtig nauwelijks voet aan de grond kreeg bleek nu wel overtuigingskracht te bezitten, omdat het over een ander dilemma ging. Deze verandering leverde ethici nieuwe kansen op om zeggenschap te verwerven. Deze afwisseling in de jurisdictie en de daarop volgende wending van het debat betekent dan ook dat de verhouding tussen juristen en ethici opnieuw gestalte werd gegeven. ${ }^{4} \mathrm{De}$ analyse van het zeggenschapsvraagstuk laat zien dat er geen sprake is van een progressief proces waaruit vanzelf de 'beste oplossing' voor een gegeven probleem naar boven komt drijven. Suggesties en argumentaties die eerder niet overtuigend waren, kunnen worden 'teruggehaald', waarna blijkt dat ze in de veranderde omstandigheden wel weerklank vinden. Dit illustreert dat er in het debat steeds bewegingen te zien zijn waardoor niet van een eenduidige vooruitgang in her debat kan worden gesproken.

In de sociaul-conceptucle analyse is onderzocht hoe het patiëntenperspectief als een vruchtbaar spoor voor her euthanasievraagstuk sterker werd. Mer de crisis in de medische ethiek verdween het paradigma van ethiek als een set beroepscodes vóór en dóór artsen naar de achtergrond. Er werd hard gewerkt aan de ontwikkeling van nieuwe concepten om het probleem van de paternalistische arts en de passieve, onwetende pariënt aan te pakken. De individueel-humanistische denkstijl bleek beter dan de sociaal-levensheschouwelijke denkstijl in staat om als leidraad te fungeren voor zowel juristen als ethici. Deze denkstijl, waarin het denken in termen van zelfbeschikking en rechten van de patiënt centraal staat, groeide vanaf de jaren zeventig uit tot een paradigma voor gezondheidsrecht en gezondheidsethiek.

Het probleem van levensbeëindiging bij wilsonbekwamen leidde wedcrom tot veranderingen, net als uit de zeggeschapsanalyse naar voren kwam. Deze vorm van levensbeëindiging bleek een moeilijk bespreekbaar onderwerp tc zijn. Ethici brachten alternatieven voor de wil van de paciënt in. Sommigen van hen gaven felle kritiek op het concept van zelfbeschikking dat als te dominant in de 
gangbare medische ethiek werd beschouwd. Hiermee verbonden werden andere ideeën over de functie van gezondheidsethiek dan als toegepaste of oplossingsgerichte ethiek geuit. Zelfreflectie van ethici op hun eigen vakgebied leidde tor kritische geluiden over de verhouding tussen gezondheidsrecht en gezondheidsethiek en over de invulling van ethiek als regelethiek. De sociaalconceptuele analyse laat zien hoe denkstijlen en paradigmata wisselen en samengaan met veranderingen in het denken van beide vakgebieden.

De netwerkanalyse heeft laten zien dat de kwestie van vragen rond het levenseinde niet zonder meer in een bestaande juridische of ethische orde kon worden opgenomen. De worsteling met dilemma's rond het levenseinde creeerde juist een specifieke juridische en ethische orde. Normen en regels ontwikkelden zich tegelijkertijd en in samenhang met de medische praktijk van levensbeëindigend handelen. Het concept van de zorgvuldigheidseisen, dat in een notendop de kern voor normering en regulering van levensbeëindigend handelen vormt, werd langzamerhand bestendigd en verwierf een stabiele status. De invulling van de zorgvuldigheidseisen werd steeds meer toegespitst en de koppeling tussen euthanasie en de medische professie werd steeds hechter. Normering en regulering waren pas mogelijk binnen een stabiel nerwerk van diverse relaties, met het vormen van een aantal koppelingen en knooppunten. Maar een stabiel rijtje voorwaarden gekoppeld aan de medische professie betekende halverwege de jaren tachtig niet dat een arts straffeloos euthanasie of hulp bij zelfdoding kon verlenen. Er was nog geen sprake van een gereguleerde praktijk. In de onderhandelingen van de verschillende opties hierover waren ethiek en recht, bij de vestiging van het netwerk, inzet van discussie.

De tot stand gekomen normering en regulering wijzigde doordat nieuwe elementen aan het netwerk werden gehangen. Zo moesten de zorgvuldigheidseisen bijvoorbeeld ook op levensbeëindiging zonderverzoek toegepast worden, toen in de jaren negentig het netwerk werd uitgebreid van euthanasie en hulp bij zelfdoding naar medische beslissingen rond het levenseinde. Hetzelfde was het geval toen ook psychiaters en kinderartsen in het netwerk werden opgenomen. Dit betekende dat de consultatie-eis en de eis van het verzoek aangepast werden. Regulering volgde in het netwerk niet per definitie pas na normering. De verhouding tussen recht en ethiek werd telkens opnieuw bepaald, afhankelijk van de wijze waarop in het netwerk nieuwe knooppunten tot stand zijn gekomen.

De drie analyses laten zien dat als zich een nieuwe situatie voordoet in het debat, bewegingen in de ontwikkeling en verhouding van recht en ethiek zijn te zien. Dit betreft een dubbele interactie: het gaat om de interactie tussen de disciplines onderling, alsmede om de interactie tussen de disciplines en maatschappelijke ontwikkelingen die doorwerken in het debat. De zeggenschapsanalyseliet zien dat gezondheidsethiek en gezondheidsrecht geen gegeven disciplines zijn met een vaste identiteit. In het debat over levensbeëindigend handelen in een 
medische context worden ethiek en recht gevormd. Het debat vormt voor ethici en juristen een kans om hun identiteit te vormen in de manier waarop ze proberen het probleem af te bakenen en zeggenschap te verwerven. De sociaal-conceptuele analyse liet zien dat er geen duidelijke scheiding is aan te brengen tussen de denkstijlen van gezondheidsrecht en gezondheidsethiek. Beide vakgebieden zijn tot ontwikkeling gekomen in een periode waarin medische ethiek als een set van beroepscodes minder dominant werd. Vervolgens kwamen er twee door zowel ethici als juristen gedeelde denkstijlen, de sociaal-levensbeschouwelijke en de individueel-humanistische. De laatste groeide uit tot een nieuw gedeeld paradigma voor beide vakgebieden, waarin respect voor zelfbeschikking en autonomie van de patiënt centraal stond. Gezondheidsrecht en gezondheidsethiek hebben dus noch persé een gedeelde, noch persé een verschillende denkstijl. De netwerkanalyse heeft laten zien dat er geen vaste rol of taakverdeling is voor ethiek en recht in normatieve debatten. Het recht komt niet altijd na de ethiek. Nieuwe normen en regels voor levensbeëindigend handelen werden tegelijkertijd en in samenhang met het debat ontwikkeld door het bouwen van een netwerk. De relatie tussen ethiek en recht was afhankelijk van de wijze waarop in dit netwerk knooppunten ontstonden, bijvoorbeeld de centrale positie van de arts bij levensbeëindigend handelen.

Zeggenschap, conceptuele ontwikkeling en netwerkbouw zijn weliswaar afzonderlijk van elkaar bestudeerd, maar de kwestie van de wilsonbekwamen makkte inzichtelijk dat de drie hoofdstukken ook grote samenhang vertonen. In alle drie de analyses bleek het probleem van de wilsonbekwamen een betekenisvol (omslag)punt te zijn in de ontwikkeling van en verhouding tussen recht en ethiek. Op het moment dat met problematiek van levensbeëindiging bij wilsonbekwamen ook kwaliteit van leven centraal kwam te staan in de discussie, veranderden de verhoudingen. De interactie tussen de disciplines en de maatschappelijke ontwikkelingen betreft dus de claims met betrekking tor de definitie van euthanasie, de cognitieve ontwikkeling en de netwerkvorming tezamen. De verschillende perspectieven zijn met elkaar verweven. Maar in dit onderzoek wordt niet gepoogd om de manier waarop definitievorming, veranderingen in het cognitieve kader en normering en regulering aan elkaar gerelateerd zijn, door middel van één enkel concept aan te duiden. De drie theoretische perspectieven vertonen weliswaar verwantschap, maar komen uit verschillende tradities. Als ze onder één theoretische noemer gebracht zouden worden, zou het werk dat in deze tradities is verzet onderbelicht worden. Bovendien zou het resultaat hiervan wat gezocht zijn, omdat alle drie de perspectieven hun eigen waarde hebben.

Wat zijn de implicaties van de verschillende analyses ten aanzien van de ontwikkeling van gezondheidsrecht en gezondheidsethiek? Zoals het onderzoek heeft laten zien is de ontwikkeling ten eerste onder meer met strijd en weder- 
zijdse afbakening gepaard gegaan. Ten tweede heeft de ontwikkeling van gezondheidsethiek en gezondheidsrecht geen deterministisch spoor gevolgd, noch is er sprake van een autonome ontwikkeling. De trajecten waren niet van te voren te voorspellen en liggen ook voor de toekomst niet vast. Nieuwe situaties zorgen voor een wending in de ontwikkeling van denkstijlen. Maar ook de eigen dynamiek - in de vorm van jurisdictie - en de manier waarop ze aan hun netwerken bouwen draagt hieraan bij. Ten derde is er geen hard onderscheid te maken tussen cognitieve en sociale karakteriseringen van disciplines. Gezondheidsrecht en gezondheidsethiek zijn noch puur cognitieve entiteiten waarin argumentatie en redeneringen centraal staan, noch twee disciplines die slechts een ordinaire machtsstrijd voeren. Het cognitieve en sociale zijn met elkaar verweven, zoals het meervoudige theoretische perspectief heeft laten zien. Er is een variatie aan dimensies - professiesociologisch, cognitief en constructivistisch nodig om de diversiteit aan aspecten te beschrijven.

Wat betekent de manier waarop in dit onderzoek recht en ethiek zijn gepresenteerd, namelijk als een strijd om zeggenschap, verantwoordelijkheden en afbakeningen, wisselende denkkaders en een dynamiek van netwerken, voor het professionele debat over de verhouding tussen ethiek en recht? In hoofdstuk twee is aangegeven dat de claims in het professionele debat over de relatie tussen gezondheidsrecht en gezondheidsethiek uitgaan van een vaste identiteit voor beide disciplines. Typeringen van de relatie tussen ethiek en recht variëren van een harmonieuze relatie tot een conflictsituatie. Hoewel auteurs verschillende invullingen geven aan de identiteit van beide vakgebieden, gaan ze er wel vanuit dat zowel recht als ethiek los van elkaar (zouden moeten) bestaan en op zijn minst een eigen identiteit (zouden moeten) hebben. Verschillen of overeenkomsten worden benadrukt om de eigen identiteit van het vakgebied te kunnen waarborgen.

De drie empirische hoofdstukken hebben laten zien dat in de manier waarop binnen gezondheidsrecht en gezondheidsethiek met vragen rond het levenseinde is omgegaan een identiteit, althans ten dele, wordt gecreëerd voor zowel ethici als juristen. Gezondheidsjuristen en gezondheidsethici bestaan bij de gratie van de worsteling met vragen en dilemma's over kwesties rond het levenseinde. ${ }^{5}$ De identiteit van juristen en ethici is niet gegeven, die ontlenen ze aan inmenging in het debat. Binnen de ethiek is daar weer discussie over, omdat er op de wijze waarop in het debat wordt geintervenieerd wordt gereflecteerd. Er zijn dus geen vooraf vast te stellen identiteiten voor recht en ethiek, zoals in het professionele debat over de verhouding tussen recht en ethiek wordt gesuggereerd, bijvoorbeeld in het boek De Siamese tweeling. Aan de ethiek wordt in dit boek een filosofische oriëntatie toegeschreven, waardoor in nieuwe situaties naar andere wegen gezocht kan worden. Het recht zou daarentegen juist kennis van problemen die elders al succesvol zijn opgelost moeten vertalen naar de 
nieuwe situatie. Wat betreft de functie en verwachtingen van het recht wordt hiermee tekort gedaan aan de rol die het recht in het euthanasiedebat heeft gespeeld. Het gezondheidsrecht is creatief en productief geweest. Het vertalen van juridische constructies naar beslissingen rond het levenseinde vergde namelijk activiteiten rond zeggenschap, denkstijlen en netwerken. Daarmee werd tegelijkertijd een identiteit voor gezondheidsrecht geproduceerd. De jurist Leenen heeft bijvoorbeeld veel werk moeten verzetten, in termen van zeggenschap, verantwoordelijkheden en netwerken om het concept zelfbeschikking ten aanzien van euthanasie geaccepteerd te krijgen. Tegelijkertijd is de ethiek niet alleen filosofisch, maar ook praktisch. Er zijn door ethici diverse concrete voorstellen gedaan bijvoorbeeld met betrekking tot de positie van de patiënt bij kwesties rond het levenseinde.

De onderlinge samenhang en interactic tussen recht en ethiek laten zien dat het professionele debat over de afbakening en rolverdeling tussen recht en ethiek er niet toe kan dienen om definitief te bepalen hoe de verhouding tussen recht en ethiek er uit zou (moeten) zien; hetzij als twee aparte disciplines met een harmonieuze relatie, hetzij als twee deels samenwerkende of competitieve disciplines op een zelfde terrein. Er is geen vastomlijnd eindpunt waartoe het debat zou kunnen leiden. De antropologische invulling van ethiek die Sporken bijvoorbeeld op een gegeven moment voor ogen had, was te weinig specifiek om er concrete richtlijnen voor beslissingen rond het levenseinde uit af te leiden. Deze invulling van het vakgebied beperkte op dat moment de mogelijkheden van de ethiek. Hetzelfde geldt voor het punt van de zelfbeschikking in het gezondheidsrecht. Op het moment dat de kwestie van de wilsonbekwamen ter discussic stond, betckende het vasthouden aan zelfbeschikking als belangrijkste criterium bij euthanasie en pijler voor het gezondheidsrecht door onder andere Leenen een beperking van het recht om de discussie over dit lastige onderwerp voort te zetten. Er is geen vaste relatie tussen recht en ethiek. De relatie tussen recht en ethiek wordt bepaald in samenhang met de ontwikkelingen in het debat. Recht en ethiek zijn - binnen bepaalde grenzen - in beweging en daardoor worden de kansen op jurisdictie, de ontwikkeling van nieuwe denkstijlen en het opbouwen van netwerken in nieuwe situaties vergroot. In de volgende paragraaf wordt de samenhang en toepassing van de meervoudige heuristiek onderzocht aan de hand van een actuele casus uit het euthanasiedebat.

\section{De kracht van het meervoudig theoretisch perspectief: de zaak Brongersma als voorbeeld}

Recht en ethiek zijn in dit onderzoek als complexe netwerken van mensen, conceptuele kaders en een strijd om afbakening van grenzen gepresenteerd. Nu de 
bril aan de hand van dit meervoudige perspectief is gescherpt is het de moeite waard om een aantal ontwikkelingen, naar aanleiding van het debat over euthanasie, nader te bekijken. In de drie empirische hoofdstukken stonden de analyses los van elkaar. Aan de hand van een casus uit het actuele debat over levensbeëindigend handelen wordt nu de samenhang tussen de verschillende analyses - het opeisen van zeggenschap, de vorming van denkstijlen en netwerken -. nader geillustreerd.

Het toepassen van het theoretisch perspectief op andere voorbeelden of casus is een manier om de winst van het betreffende perspectief zichtbaar te maken. De casus betreft de discussie over 'klaar-met-leven-situaties'. Sinds het debat over de pil van Drion in de jaren negentig staat in Nederland de vraag ter discussie of er op collectief niveau een oplossing moet worden gevonden voor de zogenoemde klaar-met-leven-situaties: ouderen die niet lichamelijk of psychisch lijden binnen een medische context, maar die niettemin wel een hartstochtelijke doodswens hebben. Is het bij somatische en psychische klachten al een moeilijke taak voor een arts om het lijden te beoordelen, bij lijden als gevolg van de levensfase waarin iemand verkeert lijkt dit welhaast een onmogelijke taak. De discussie over klaar-met-leven-situaties is recent opgelaaid naar aanleiding van de zaak Brongersma (Van Ree 200r).

In de zaak Brongersma gaat het om de hulp bij zelfdoding die de huisarts Sutorius in 1998 aan de 86-jarige oud-PvdA senator Brongersma heeft gegeven. Brongersma stelde dat de dood hem was vergeten. Hij was eenzaam en vreesde voor verdere aftakeling. Zijn lijden werd niet veroorzaakt door een slopende ziekte, noch door een psychiatrische aandoening. Zijn lijden was grotendeels existentieel; Brongersma leed kennelijk als gevolg van zijn levensfase. Hij kon niet meer het actieve en erudiete leven leiden dat hij altijd gewend was geweest. Hij diende bij zijn huisarts Sutorius een verzoek tor levensbeëindiging in. Sinds de jaren tachtig heeft de arts een formele rol gekregen bij de besluitvorming rond euthanasie en hulp bij zelfdoding. Hij heeft deze verantwoordelijkheid op basis van zijn medische kennis en ervaring verkregen. Dit onderzoek heeft laten zien hoe juristen en ethici hebben meegewerkt aan de toebedeling van deze verantwoordelijkheid aan de arts. Ondanks de belangrijke rol die de autonomie van de patiënt tegenwoordig speelt bij beslissingen rond het levenseinde is het de arts die na een verzoek tot levensbeëindiging het lijden van de patiënt moet beoordelen op ondraaglijkheiden uitzichtloosheid. Dit lijden, dat vaak een combinatie is van somatisch en psychisch lijden, wordt als gevolg van de medische diagnose 'geobjectiveerd' of krijgt op zijn minst de status van een medisch erkende vorm van lijden. Pas dan kan het verzoek tor levensbeëindiging serieus in overweging worden genomen. Op grond van zijn medische expertise en betrokkenheid bij de uitvoering heeft de arts dus grote zeggenschap in de beslissing om over te gaan tot levensbeëindiging. 
In november 2000 sprak de rechtbank van Haarlem Sutorius vrij van hulp bij zelfdoding. Het ом ging hier echter tegen in beroep, omdat het twijfelde of in dit geval wel sprake was geweest van zorgvuldig handelen. Ter discussie stond onder meer de reikwijdte van het begrip ondraaglijk en uitzichtloos lijden. Het ом stelde de vraag of door dit specifieke geval van hulp bij zelfdoding het criterium van ondraaglijk en uitzichtloos lijden niet te veel werd opgerekt. Met andere woorden, het om wilde door middel van jurisprudentie duidelijkheid krijgen over de reikwijdte van het criterium ondraaglijk en uitzichtloos lijden. Kan hulp bij zelfdoding ook gegeven worden bij afwezigheid van een zwaarwichtige medische diagnose? In het hoger beroep van deze zaak heeft het gerechtshof in Amsterdam Sutorius veroordeeld voor zijn hulp bij zelfdoding, maar hem geen straf opgelegd. Het hof was er namelijk van overtuigd dat Sutorius had gehandeld vanuit een grote betrokkenheid bij en mededogen met zijn patiënt. Sutorius had de stellige overtuiging dat Brongersma ernstig leed en dat dit lijden niet te verzachten zou zijn geweest. Sutorius' motivatie om Brongersma te helpen was gelegen in de opvatting dat hij zijn patiënt niet in de steek mocht laten. Het argument van barmhartigheid bood hier kennelijk mogelijkheden om de lastige beslissing te verdedigen. Hij deed daarom een beroep op de noodtoestand waarin hij als arts verkeerde.

In het debat over de zaak Brongersma is de v'rantu'oordelijkhcidvan de arts inzet van discussie. De twee getuige-deskundigen in het hoger beroep van deze zaak, de hoogleraar gezondheidsrecht Legemaate en de hoogleraar integratie geneeskundige zorg voor chronisch zieken Spreeuwenberg, verklairden beiden dat artsen geen taak hebben inzake stervenshulp aan mensen die 'slechts' oud en der dagen zat zijn. Volgens hen kan een arts alleen over het gebied van ziekren, 'her domein van de arts', uitspraken doen. Zonder een lichamelijke of psychische aandoening zou onduidelijk zijn op grond van welke deskundigheid een arts dan de uitzichtloosheid van het lijden van de patiënt zou moeten beoordelen. De tot nu toe in de praktijk gegroeide legitimatie voor stervenshulp door een arts zou in een geval van existentiële nood ontbreken. De klaar-met-levensituaties classificeren de beide getuigen-deskundigen dus buiten het medische domein en voor stervenshulp buiten her dit domein bestaat volgens hen geen verantwoordelijkheid voor artsen.

Op grond van deze vraag naar verantwoordelijkheden zou de nieuwe 'klaar-mer-leven-problematiek' een maatschappelijk probleem zijn. Als er binnen de samenleving consensus is dat op collectief niveau een oplossing voor dit probleem gevonden moet worden, dan staat vervolgens de verantwoordelijkheid van de arts hierbij ter discussie. Ten eerste zou een verantwoordelijkheid voor deze problematiek bijvoorbeeld bij speciale lijdensdeskundigen gelegd kunnen worden. Als oplossing voor dit vraagstuk suggereert Spreeuwenberg een speciaal 'Rijksbureau ter Verstrekking van Dodelijke Middelen' (Visser 200r). 
De politieke verantwoordelijkheid voor dit vraagstuk komt daarmee bij de overheid te liggen. Ondertussen voelt de KNMG zich wel betrokken bij deze problematiek. Zij heeft een speciale commissie in het leven geroepen, de commissie Dijkhuis, om deze problematiek verder te bestuderen (Crul 200I). Een vraag die hierbij speelt is of het maken van een onderscheid tussen ziekte en verschijnselen als gevolg van normale ouderdom eigenlijk wel mogelijk is. ${ }^{6}$ Het ziektebegrip is immers een begrip dat in beweging is. Wat als ziekte wordt gezien en wat niet is het resultaat van de manier waarop binnen de medische professie en de samenleving tegen dat begrip wordt aangekeken. Dit illustreert dat de zeggenschap en verantwoordelijkheid van de arts hierover niet vastliggen. Het is dus de vraag of de arts bij de stervenswens van ouderen, waar niet direct een medisch aanwijsbare oorzaak is voor hun lijden, een verantwoordelijkheid heeft. Wellicht dat geriaters in de toekomst een grotere zeggenschap over deze kwestie gaan opeisen of toebedeeld krijgen op grond van hun expertise op dit terrein.

Een tweede mogelijkheid is dat ouderen in toenemende mate zelf op zoek zullen gaan naar informatie en advies om aan dodelijke middelen te komen. In zijn boek Sterfwerk laat de psychiater Chabot zien hoe enkele ouderen en ernstig zieken hun zelfdoding in eigen kring hebben geregisseerd (Chabot 200I). Chabot beschrijft 18 casus van ouderen en ernstig zieken die, onder begeleiding van consulenten en voorlichters van de Nederlandse Vereniging voor Vrijwillige Euthanasie (NVVE) en de stichting De Einder tot hun zelfdoding zijn gekomen. In een paar gevallen gebeurde dit zonder assistentie van een arts. Als dit een groeiende praktijk zou worden, zou daarmee een proces van ontmedicalisering van het zelfgekozen einde in gang kunnen worden gezet.?

In de discussie over het vraagstuk van de 'klaar-met-leven-situaties' staan de diverse verantwoordelijkheden ter discussie. Het is thans nog niet duidelijk hoe en door wie hier een oplossing voor moet worden gevonden en wie hier al dan niet zeggenschap in heeft. De huisarts Sutorius heeft in de zaak Brongersma aangegeven dat het wat hem betreft een speciale kwestie tussen arts en patiënt is (Oostveen 200r). Juristen zouden niet over het geschikte beoordelingsvermogen hiervoor beschikken, omdat zij niet, zoals artsen, met handen en voeten in de praktijk staan. Zij zouden niet de specifieke 'chemie' tussen arts en patiënt kunnen begrijpen. Dit onderzoek heeft echter inzichtelijk gemaakt dat de klok niet zomaar teruggedraaid kan worden. De context van de zaak Brongersma verschilt bijvoorbeeld in vele opzichten van die van de zaak Postma in 1973. Op dat moment had het begrip euthanasie nog een brede invulling. Euthanasie en hulp bij zelfdoding waren begin jaren zeventig nog niet aan het handelen van een arts gekoppeld. Dergelijke handelingen waren dan ook niet toetsbaar. Gezien de geschiedenis staan nu niet zonder meer dezelfde opties open als dertig jaar geleden. Levensbeëindigend handelen van de arts is in enkele decennia toetsbaar gemaakt. Dit handelen van de arts, zo is de huidige opvatting, moer 
door de maarschappij gecontroleerd kunnen worden. I) inmenging vall juristen met deze problemariek is dan onk niet simpelweg meer terug te draaicn.

Naast de verantwoordelijkheid van de arts is ook het autonomie-denken inzer van de discussie. Euthanasie en hulp bij zelfdeding worden in Nederland gerechtvaardigd door een beroep op de autonomie van de patiënr. Maar in de zaak Brongersma stond het gewicht van de zelfbeschikking van de patiïnt, zijn doodswens, ten opzichte van het uiteindelijke medische professionele oordeel ter discussie. Een beroep op de autonomie van Brongersma was in de ogen van de rechtbank van Haarlem een voldoende rechtvaardiging voor het handelen van Sutorius. De rechtbank volgde daarbij het advies van de getuige-deskundige De Beaufort, hoogleraar medische ethiek. De redenering luidde dat respect voor de autonomie van het individu betekent dat het eigen oordeel met betrekking tor de ondraaglijkheid van iemands lijden de belangrijkste leidraad is. Met andere woorden, de ondraaglijkheid van lijden kan alleen door de betrokkene zelf ervaren worden, ook als dit lijden geen psychische of somatische oorzaak heeft. In het hoger beroep van de zaak is deze legitimatie van het beroep op de autonomie van de patiënt in twijfel getrokken. Om de autonomie van de patiënt te realiseren waren oordeel en handeling van de arts nodig. In termen van wie hier nu zeggenschap over heeft werd de ethische expertise van De Beaufort ondergeschikt gemaakt aan het betoog van Legemaate en Spreeuwenberg. Het argument van autonomie was dus in eerste instantie vanuit de ethiek en voor de rechtbank een overtuigend argument, maar in tweede instantie, tijdens het hoger beroep, geen voldoende legitimering meer. Dit bevestigt de conclusie uit hoofdstuk vijf dat het recht niet standaard de ethiek volgt; er is geen vaste rolverdeling tussen regulering en normering. Telkens ontwikkelt zich en ontstaat er een nieuwe normatieve en regulatieve orde. Bovendien laat de argumentatie van De Beaufort en Legemaate zien dat er vanuit het recht niet altijd strak wordt vastgehouden aan de lijn van respect voor autonomie van de patiënt. In de zaak Brongersma wordt vanuit de ethiek veel waarde gehecht aan de autonomie van de patiënt, terwijl vanuit het recht de casus in een breder perspectief wordt geplaatst.

Het autonomie-denken heeft in het debat over euthanasie en hulp bij zelfdoding altijd een belangrijke rol gespeeld. De zaak Brongersma richt de aandacht op de spanning die ontstaat bij een poging om het zelfbeschikkingsregime rond levensbeëindiging uit te breiden. Het concept zelfbeschikking kan uitgebreid worden, zodat ook gevallen als de zaak Brongersma hicr onder zouden kunnen vallen. Het concept heeft echter in de manier waarop tot nu toe over euthanasie is gesproken niet die specifieke en ruimere invulling gehad. ${ }^{8} \mathrm{Om}$ tor die invulling te komen zal niet alleen de reikwijdte van het concept, maar ook het concept zelf als gevolg van ontwikkelingen in her rucht en dc cthick moeten veranderen. Welke rol het berocp op de autonomie van de pariënt zal 
gaan spelen in de nieuwe levensfaseproblematiek is nog niet duidelijk. Volgens Legemaate is hier nog geen oordeel over te vinden in de rechtspraak (Visser 200I). Dit denken zal zich onder meer aan de hand van casus zoals de zaak Brongersma moeten ontwikkelen.

Regelgeving voor levensbeëindigend handelen is in een uitgebreid normatief en regulatief netwerk ontwikkeld. Dit netwerk is specifiek rond euthanasie - gedefinieerd als levensbeëindiging op verzoek door een arts - uitgekristalliseerd. Euthanasie wordt in Nederland expliciet niet als 'normaal medisch handelen' beschouwd. Vandaar dat er speciale voorwaarden en regels zijn om dit handelen in banen te leiden. Eén van die voorwaarden is het ondraaglijk en uitzichtloos lijden van de patiënt. Dat betekent dat het niet vanzelfsprekend is dat relatief nieuwe gevallen, zoals 'klaar met leven-situaties', aan deze voorwaarden gekoppeld kunnen worden. De manier waarop het debat over euthanasie is gevoerd is dusdanig ingebed in een netwerk van specifieke koppelingen dat plorselinge koerswijzigingen niet aannemelijk zijn. Het netwerk rond euthanasie en de interactieve ontwikkelingen tussen recht en ethiek zijn niet simpelweg een afgerond geheel op welk moment dan ook. Dat maakt het gecompliceerd om bepaalde 'onderdelen' over te plaatsen naar andere discussies, zoals 'klaar-metleven-situaties'. Dit kan alleen als het netwerk zou worden uitgebreid, met alle risico's van dien.

Kortom, in het debat over 'klaar-met-leven-situaties' staan issues als wie hier zeggenschap over heeft of moet hebben en welke plaats het autonomiedenken hierbij inneemt en het opbouwen van een netwerk rond klaar-met-leven-situaties thans op de maatschappelijke agenda. Met de zaak Brongersma is niet meteen duidelijk of dit het begin van een nieuwe richting in het debat is of niet. Wil deze zaak daadwerkelijk een wending betekenen, dan moet er nog heel wat gebeuren in termen van conflicten, strijd en netwerk. Deze verschillende elementen zijn onderling aan elkaar zijn gerelateerd. Dat betekent dat bij het aanpakken van één aspect van het dilemma van klaar-met-leven situaties dit consequenties heeft voor de andere aspecten. Hoewel de zaak Brongersma door critici kan worden aangegrepen als een voorbeeld van een mogelijke hellend vlak situatie in het Nederlandse debat over vragen rond het levenseinde, kan op grond van deze meervoudige analyse het tegenovergestelde worden beweerd. Argumenten zoals de eventueel nog grotere relevantie van de autonomie van de patiënt en de kans op een geringere tolerantie jegens ouderen worden in de zaak Brongersma aangevoerd ter illustratie van een liberale trend in het Nederlandse debat over medische beslissingen rond het levenseinde (Mölller \& Huxtable 200I). Dit onderzoek laat echter zien dat de verwevenheid van de verschillende elementen maakt dat eerst nog veel werk verzet zal moeten worden voordat dit type vragen, de klaar-met-leven-kwesties, een stabiel onderdeel is van het debat rond levensbeëindigend handelen.' Zoals eerder genoemd zou daarvoor bij- 
voorbeeld het concept van autonomie tegelijkertijd met ontwikkelingen in het recht en de ethiek moeten veranderen in het netwerk van de klaar-met-levenkwesties en vragen rond het levenseinde.

\section{Lopen ethiek en recht achter de feiten aan?}

Waar staan ethiek en recht bij de regulering van morele vraagstukken? Op de achtergrond van de vraag naar de rol van recht en ethiek in het debat over levensbeëindigend handelen speelt de meer algemene vraag naar de rol en betekenis van ethiek en recht in actuele en morele maatschappelijke debatten. In de literatuur wordt soms het beeld geschetst van ethiek en recht die achter de maatschappelijke ontwikkelingen aan lopen. Eén van de eerste kritieken in deze lijn, met betrekking tot de ethiek, is het al eerder genoemde boek Geneeskunde tussen droom en drama. 'Alles overziend, lijkt de groei van de medische ethiek als discipline niet gepaard gegaan te zijn met een evenredige toename van haar invloed op het medisch handelen. De ontplooiing van medische technologie sinds 1960 heeft zich in feite buiten haar om voltrokken. De ethiek heeft achter de ontwikkelingen aan gelopen' (Ten Have \& Kimsma 1987: 175). Volgens Ten Have en Kimsma zou de ethiek een minder volgende en meer kritische rol moeten hebben. Ze pleitten eind jaren tachtig dan ook voor een 'offensieve ethiek' (p. 88). In het boekje Gerede twijfel. Over de rol van medische ethiek in Nederland werd eveneens kritiek geuit op de rol van ethiek (De Vries 1993a). Ethici zouden te loyaal naar de medische praktijk zijn, waardoor de ethiek in plaats van kritisch te zijn richting de medische praktijk er eerder mee vergroeid was (p. 37).

Ook binnen het recht is gesignaleerd dat recht achter de ontwikkelingen aan loopt. In zijn oratie Dynamisch rechtstelde de jurist Van der Burg dat het recht een volgende rol heeft in de samenleving. 'Meestal loopt het recht achtur de maatschappelijke ontwikkelingen aan en reageert aan de late kant, en dan ook nog soms op minder gelukkige wijze. Telkens als dat gebeurt schiet her recht eigenlijk tekort' (Van der Burg 200I: 9). Van der Burg deed een voorstel om dit probleem deels te ondervangen. In zijn perspectief is recht een spanningsveld tussen dynamiek en stabiliteit. Hij streeft naar een 'rechtswetenschap der voorlopigheid'; naast een reactieve rol ziet hij namelijk ook een proactieve rol voor de rechtswetenschap. Deze laatste functie zou de rechter en de maatschappelijke praktijk enige houvast moeten geven als ze met nieuwe ontwikkelingen worden geconfronteerd.

Vanuit eenzelfde idee worden sinds een paar jaar door de overheid eveneens initiatieven ontplooid om beleidsbeslissingen ten aanzien van ethische problemen beter aan te kunnen pakken. Door de snelle (technologische) ontwikkelingen is de overheid vaak te weinig voorbereid op ethische problemen, met als 
gevolg dat er vaak snel een standpunt moet worden ingenomen. De Raad voor de Volksgezondheid en Zorg (Rvz) heeft in een advies over dit probleem voorgesteld om een kenniscentrum voor ethische vraagstukken op het terrein van de gezondheidszorg op te richten (RVz 1999). Dit kenniscentrum, het Centrum voor Ethiek en Gezondheid (CEG) moet een ethische agenda voor de toekomst opstellen en ondersteuning bieden bij de aanpak van ethische problemen. ${ }^{10}$

Kortom, er zijn verschillende plannen om vanuit het recht en de ethiek meer te anticiperen op actuele kwesties. De vraag is of het uitgangspunt van deze initiatieven klopt en wat er te zeggen is over de mogelijkheden en beperkingen van deze plannen op grond van dit onderzoek. Dit onderzoek heeft inzicht gegeven in de rol van recht en ethiek in het debat over levensbeëindigend handelen. Daarbij bleek dat er op voorhand geen normatieve of juridische consensus was waar men zich op kon baseren. Daarom zijn handboeken gezondheidserhiek en gezondheidsrecht geen primair richtsnoer geweest bij de normering en regulering van levensbeëindigend handelen. Het ontbrak aan een consensus over een ethische of juridische fundering voor het euthanasiedebat. Er was namelijk geen vooraf gegeven expertise die direct kon worden ingezet of op het nieuwe vraagstuk kon worden toegepast. Dit geldt ook voor de klaar-met-leven-situaties zoals in het voorbeeld van de zaak Brongersma. Dit onderzoek illustreert dat inzichten binnen de ethiek en het recht niet voor het oprapen liggen, integendeel (nieuwe) kennis wordt - in interactie met de betreffende issues - ontwikkeld, ten koste van veel werk, afbakening, denkstijlen en netwerken.

De inspanning van diverse betrokken actoren en de interactie tussen recht en ethiek hebben tot een bepaald begrippenkader voor de normering en regulering van euthanasie geleid. Begin jaren zeventig was bijvoorbeeld nog niet duidelijk om wat voor soort probleem het bij de vragen rond het levenseinde ging; er stond een meervoudige problematiek op de maatschappelijke agenda. Dat betekent dat er ook een gevarieerd scala van oplossingen mogelijk was. Pas halverwege de jaren tachtig, na het uitkristalliseren van de definitie van euthanasie, werd een orde aangebracht in de manier waarop een oplossing kon worden gevonden. Er was onderscheid gemaakt tussen euthanasie en schijngestalten van euthanasie. Het ging om levensbeëindigend handelen op verzoek, alle andere vormen van levensbeëindiging stonden tijdelijk buiten het aandachtscentrum. Hoewel er, zoals het onderzoek heeft laten zien, al ontwikkelingen in het recht en de ethiek rond levensbeëindigend handelen waren vóórdat de definitie van euthanasie een feit was, konden specifieke en op het toen uitgekristalliseerde probleem toegespitste oplossingen pas inzet van discussie worden nádat deze definitie was uitgekristalliseerd: bijvoorbeeld de positie van de arts, zorgvuldig medisch handelen en het vormgeven aan de autonomie van de patiënt bij levensbeëindigend handelen. Hoewel de indruk wordt gewekt dat recht en ethiek achter de feiten aanlopen, ontwikkelde het onderwerp zich in interactie 
met ethiek en recht. Voor de klaar-met-leven-situaties geldt bijvoorbeeld, zoals in de derde paragraaf van dit hoofdstuk is aangegeven, dat deze kwestie tegelijkertijd met de juridische en ethische ontwikkelingen gestalte kreeg. Deze ontwikkelingen zijn niet uit elkaar te halen.

Dat betekent dat het idee dat recht en ethiek achter de feiten aan zouden lopen niet klopt. Een beleidsprobleem is geen blanco discussie, maar een reeds afgebakend probleem: ethische en juridische aspecten zijn al enigszins uitgekristalliseerd. Soortgelijke ideeën zijn door Hajer uitgewerkt in zijn boek The politics of environmental discourse (Hajer 1995). Hierin heeft Hajer de opkomst van ecologische modernisering als nieuw dominant beleidsdiscours onderzocht. Vanuit sociaal-constructivistisch perspectief vat Hajer beleid op als een 'discursive closure'. Beleid maken is in deze opvatting een interpretatieve activiteit, waarin verschillende en vaak ook tegengestelde claims van betrokken actoren over wat het probleem zou zijn worden gecombineerd. Dar betekent dat elke probleemdefinitie kritisch bekeken zou moeten worden. Beleid is dus vanuit dit perspectief niet simpelweg een vorm van 'problem closure', dat wil zeggen dat door middel van beleid een set acceptabele oplossingen voor een afgebakend probleem wordt geformuleerd. Integendeel, beleid is zelf ook onderdeel van het proces van het definiëren van een set van sociaal-geaccepteerde en welomschreven problemen. Het geven van advies hierover gebeurt in een gebied waar al wat over is gezegd. De discussie begint niet helemaal van voren af aan. Dat gaat ook op voor medisch-ethische debatten, zoals bijvoorbeeld kwesties rond levensbeëindigend handelen. Ook daar circuleren verschillende probleemdefinities die het resultaat zijn van onderhandelingen, strijd en zeggenschapskwesties waar ethici en juristen volop aan mee hebben gedaan.

Vanuit bovenstaand beleidsperspectief is er voor ethici en juristen dan ook niet slechts een adviserende rol weggelegd wanneer er een beleidsprobleem ligt bij een commissie. In de literatuur lijken voornamelijk op dat moment adviesgerichte verwachtingen van ethici en juristen te bestaan. Ethici en juristen spelen bijvoorbeeld, naast artsen, een prominente rol in verschillende toetsingscommissies en adviesorganen. Hierbij gaat het dan vooral om advisering op basis van wetenschappelijk onderzoek." Vanuit het gangbare beleidsperspectief wordt van ethici en juristen, bijvoorbeeld in de Beraadgroep ethiek en recht van de Gezondheidsraad, vooral een adviserende en toetsende functie verwacht (Nieuwenkamp 1993: 38). Onderhavig onderzoek heeft echter laten zien dat ethici en juristen in medisch-ethische debatten reageren op eerdere acties en anticiperen op bepaalde reacties. Ze verrichten meer werk dan op het eerste gezicht duidelijk is, omdat de aard van het werk relatief onzichtbaar is. Aan het huidige begrippenkader van beslissingen rond het levenseinde hebben ethici en juristen bijvoorbeeld hard meegewerkt. De empirische hoofdstukken geven inzicht in dilemma's rond het levenseinde als de uitkomst van een historisch 
geconstrueerde set van claims. Deze claims door deskundigen waren op hun beurt weer gekoppeld aan bepaalde oplossingen. Van recht en ethiek kan dan ook niet slechts een adviserende functie worden verwacht op het moment dat er al een beleidsprobleem is geformuleerd. De rol van ethiek en recht bij de regulering van deze problematiek moet vanuit een breder perspectief, zoals uitgewerkt in de verschillende analyses, worden beoordeeld.

Dat betekent dat ook bij de problematiek van de 'klaar-met-leven-situaties', zoals de beknopte analyse van de zaak Brongersma liet zien, ontwikkelingen rond recht en ethiek al in gang zijn gezet. Het spel van het toebedelen en toeeigenen van verantwoordelijkheden en het gebruik van bepaalde denkramen is reeds volop bezig. Er zijn diverse claims over de verantwoordelijkheid van de arts, het eigen oordeel van de patiënt over de ondraaglijkheid van het lijden en bijvoorbeeld de rol die geriaters bij deze problematiek zouden kunnen gaan spelen. Het netwerk rond klaar-met-leven-situaties wordt verder geconstrueerd. Kortom, initiatieven om meer te anticiperen op ethische en juridische aspecten van maatschappelijke ontwikkelingen sluiten aan bij het geschetste beeld van ethiek en recht. Empirisch onderzoek naar de context van een moreel issue kan uitwijzen wat de diverse claims zijn, waar ze vandaan komen en hoe ze gecombineerd werden, ervan uirgaande dat her betreffende probleem een historisch geconstrueerde set van claims is.

Toch moet voor een al te groot optimisme ten aanzien van het kunnen beheersen van medisch-ethische kwesties worden gewaakt. Zo wekt de voorlopige agenda 'Ethiek en Gezondheid' de indruk dat met het in werking treden van de wet levensbeëindiging op verzoek en hulp bij zelfdoding in 2002 de ethische problemen voor dit onderwerp voorlopig voorbij zouden zijn (vws 200r). Dit onderzoek heeft echter laten zien dat discussies over een onderwerp nooit definitief zijn. Nieuwe ontwikkelingen leiden weer tot veranderingen. Ondanks de wet ligt niet vast hoe de zorgvuldigheidseisen geïnterpreteerd moeten worden. Om de juiste normen vast te stellen zijn nog steeds uitspraken van de rechter nodig. Een wet kan niet alles vast leggen, maar betekent vanuit het in dit onderzoek gepresenteerde analytische kader een nieuwe ronde met nieuwe mogelijkheden, bijvoorbeeld voor de wilsonbekwamen: in de wet zijn regelingen opgenomen met betrekking tot dementen en wilsverklaringen wat betreft de wil om de regie over het levenseinde zoveel mogelijk in eigen hand te nemen. Bovendien laat dit onderzoek zien dat de mogelijkheden om te anticiperen niet volledig open liggen, maar gebaseerd zijn op het netwerk dat in aanbouw is zoals her voorbeeld van de zaak Brongersma inzichtelijk heeft gemaakt. Kortom, ontwikkelingen binnen de ethiek en het recht zijn enerzijds begrensd, maar zijn anderzijds niet van te voren te voorspellen of te bepalen. Ze zijn het resultaat van de manier waarop in debatten strijd over zeggenschap wordt gevoerd, conceptuele ontwikkelingen plaatsvinden en netwerken worden gebouwd. 


\section{NOTEN}

\section{Noten bij hoofdstuk I}

I In 1994 is een themanummer van het tijdschrift Gezondheid. Theorie in Praktijk gewijd aan het 'proceduralisme in de gezondheidsethiek'. Daarin werd onder andere de vraag aangesneden of in de loop van de ontwikkeling van de ethiek her normatieve niet steeds meer plaats had gemaakt voor het procedurele in verband met praktische belangen. 'De vraag wordt dus opgeworpen of de gezondheidsethiek niet haar ziel heeft verkocht ter wille van haar respectabiliteit in de wereld van de medici en beleidsmakers' (Houtepen \& Widdershoven 1994).

2 De socioloog Schuyt verstaat onder juridisering de transformatie van spontane sociale relaties in juridische relaties, zodanig dat deze sociale relaties voornamelijk gedefinieerd worden in juridische termen (verplichtingen, aansprakelijkheden). Een tweede betekenis van juridisering heeft betrekking op het maatschappelijk proces waarin genoemde transformatie op steeds meer terreinen van de maatschappij optreedt. Zie meer hierover in: 'Tussen witte jassen en zwarte toga's: medicalisering en juridisering' in: Tegendraadse werkingen, C.J.M. Schuyt (1995).

Ook Legemaate en Casparie signaleren dit verschijnsel, met name in de psychiatrie. Juridisering is voor Casparie de beweging dat wet- en regelgeving steeds meer het toetskader of referentiekader wordt van het handelen in de samenleving. Bij juridisering gaat het erom of er in overeenstemming met wetten en regels is gehandeld. Zie meer hierover in: 'Is de toekomstige kwaliteit van zorg door juridisering van het medisch beroep nog wel gegarandeerd? - de mogelijke invloed van de BIG, in: Lex medicorum, (1991) Liber amicorum Prof. Mr. W.B. van de Mijn. (red.) J.M. Bruggeman, A.F. Casparie, H.E.G.M. Hermans, R.M.J. Schepers.

Legemaate stelt dat vanuir de hulpverlening regelingen als de WGBO en de вOPZ als juridisering worden gezien. Het gaat daarbij om de spanning tussen recht en realiteit. Zie: 'Normen en grenzen in de psychiatrische behandeling: beschouwingen over juridisering', in: Tijdschrift voor Psychiatrie, 38, 3, p. 251-262, 1996.

3 Praktijk betekent in dit verband dat het debat over levensbeëindigend handelen wordt bestudeerd, dat wil zeggen: artikelen, boeken, lezingen en congressen vormen het empirisch materiaal. Het begrip praktijk heeft dus niet betrekking op observaties of etnografisch onderzoek in bijvoorbeeld ziekenhuizen of medisch-ethische commissies.

4 In de Verenigde Staten wordt de term bioethics vaker gebruikt. In hoofdstuk twee wordt her gebruik van de verschillende termen, medische ethiek, ethiek van de gezond- 
heidszorg en bio-ethiek verder toegelicht. In het onderhavige onderzoek wordt de 'medische ethiek' als een 'arena' beschouwd, waarin recht en erhiek zich hebben begeven. Medische ethiek wordt dus niet als een aparte discipline of vakgebied beschouwd.

5 Navraag bij Jettinghof van de vakgroep Metajuridica van de Universiteit Maastricht en Griffiths van de sectie rechtssociologie aan de Universiteit van Groningen heeft dit beeld bevestigd. Historische rechtssociologie op het terrein van het gezondheidsrecht is in Nederland niet voorhanden.

6 In het onderhavige onderzoek is gebruikt gemaakt van literatuur uit het professionele debat over euthanasie, dat wil zeggen monografieën en rijdschriften waarin door ethici en juristen wordt gepubliceerd, bijvoorbeeld: Tijdschrift voor Geneeskunde en Ethiek, Medisch Contact, Nederlands Tijdschrift voor Geneeskunde, Tijdschrift voor Gezondheidsrecht, Rooms Katholieke artsenblad, Soteria, Metamedica. Er zijn interviews gehouden met sleutelfiguren uit ethiek, recht en geneeskunde die een prominente rol in het euthanasiedebat hebben gespeeld. Deze interviews hebben als achtergrondinformatie voor het onderzoek gediend. De volgende personen zijn geïnterviewd: P.V. Admiraal, I.D. de Beaufort, H.Th.P. Cremers, G.A. den Hartogh, R.J.M. Dillmann, H.M. Dupuis, J. Griffiths, H.J. Heering, W.R. Kastelein, H.M. Kuitert, H.J.J. Leenen, J. Legemaate, C. van der Meer, J.F. Rang, J.J. Rasker, C.J.M. Schuyt, E.Ph.R. Sutorius, H. Zwart. Een aantal van deze interviews is verwerkt in een artikel (Kater 2002).

7 Kennedy, een Amerikaanse hoogleraar Europese geschiedenis, heeft een cultuurhistorische analyse van het publieke debat over euthanasie in Nederland geschreven. Daarin betoogt hij dat de typisch Nederlandse hang naar 'bespreekbaarheid' vormgevend is geweest voor ons huidige euthanasiebeleid (Kennedy 2002).

\section{Noten bij hoofdstuk 2}

I Een rondvraag langs verschillende vakgroepen en instituten leert dat er minstens dertig onderzoekers/docenten met een vaste aanstelling zijn op het gebicd van cuhick in recht. Daarnaast is er nog een schare aan werknemers met een tijdelijk contract.

2 Naast de handboeken zijn er ook 'inleidingen' gezondheidsrecht verschenen. Bijvoorbeeld: Hoofdstukken over gezondheidsrecht (Verbogt 1992) en Regulering van gezondheidszorg (Dute \& Hermans 2000).

3 Een voorbeeld van het eerste is te vinden in: Voordelen van de twijfel (Dupuis \& Thung 1983: 7). Een voorbeeld van het tweede is te vinden in: Geneeskunde tussen droom en drama, (Ten Have \& Kimsma 1987: 9) en van het derde in: Wat zou u doen? (Dupuis \& De Beaufort et al. 1994).

4 Dit stappenplan komt overeen met de standaard aanpak van morele problemen zoals die is gepresenteerd in een boek over diverse vormen van toegepaste ethiek: Ethiek in de praktijk (Van Willigenburg \& Van den Beld et al. 1993: 55-70).

5 Zo was het eerste preadvies door Leenen geschreven met als titel 'Gezondheidsrecht - een poging tot een plaatsbepaling' (Leenen i968). Vervolgens werd er jaarlijks een preadvies gepresenteerd. 
6 Zie verslag jaarvergadering VFG 1999, p. 2. In dit verslag wordt ook over mogelijke samenwerking met de NVBE gesproken, omdat de VFG zou kampen met een afnemende belangstelling voor de georganiseerde activiteiten.

7 Eind jaren zestig definieerde Leenen het gezondheidsrecht als volgt: 'het geheel van rechtsregels dat rechtstreeks betrekking heeft op de zorg voor bedreigde of beschadigde gezondheid en de toepassing van overig burgerlijk recht en strafrecht voor zover deze de rechtsverhoudingen in de gezondheidszorg bepalen' (Leenen 1968: 778). De definitie is in de loop der jaren dus enigszins aangepast, maar heeft geen grote wijzigingen ondergaan.

8 'Zijn pleidooi voor een specialisme gezondheidsrecht fundeerde hij op twee overwegingen, namelijk dat voor de beoefening van het recht op het gebied van de volksgezondheid een bepaalde maatschappelijke instelling is vereist, welke afwijkt van die, welke elders bij de beoefening van de rechrswetenschap noodzakelijk is, en voorts dat de materie van her gezondheidsrecht zowel kwantitatief als kwalitatief van zodanig belang is, dat de bestudering als specialisme gerechtvaardigd is' (Leenen 1978: 184).

9 'De beslissende veranderingen, die onze tijd kenmerken en die het terrein van medische zorg en gezondheidszorg raken, maken een rechtsregeling van de omstandigheden en vraagstukken, die door deze veranderingen zijn ontstaan, bijzonder dringend' (Leenen 1968: 780).

Io In een persoonlijke terugblik op zijn leven heeft Leenen zelfs een volledig hoofdstuk gewijd aan de ontwikkeling van het gezondheidsrecht als wetenschappelijke discipline (Leenen 200ob).

II Begin jaren negentig leek de situatie bij gezondheidsrecht nog steeds nier bijzonder rooskleurig te zijn. Een onderzoekscommissie van de KNAw, die met het onderzoek naar de plaatsbepaling en definiëring van onder andere gezondheidsrecht en gezondheidsethiek was belast, kwam tor de conclusie dat de middelen voor wetenschappelijk onderzoek in het gezondheidsrecht 'volstrekt onvoldoende' waren (KNAW 199r: 45). In zijn voordracht voor de KNAW-workshop in 1996, over gezondheidsechiek en gezondheidsrecht, bracht de hoogleraar gezondheidsrecht Gevers dic punt eveneens onder de aandacht (Gevers 1996).

12 Anno 2000 zijn er zeven (bijzondere) leersroelen op her terrein van her gezondheidsrecht aan de Nederlandse universiteiten ingesteld.

I3 In dat zelfde jaar was ook Rang onderwijs in het gezondheidsrecht gaan geven tijdens zijn ambt van hoogleraar arbeidsrecht aan de Universiteit van Utrecht en niet veel later werd hij bijzonder hoogleraar gezondheidsrecht in Leiden (Leenen 1993). Bij de aanvaarding van dit ambr hield Rang een oratie over het patiëntenrecht (Rang 1973). Onder patiëntenrecht verstond Rang 'dat deel van het gezondheidsrecht dat zich speciaal bezighoudt met de rechten en plichten van de mens die enige vorm van gezondheidszorg ontvangt of moet ontvangen, of omdat hij ziek is of om te voorkomen dat hij ziek wordt' (Rang 1973: is).

I4 In een heel vroeg stadium was er ook discussie geweesr over de 'juridische' invulling van her gezondheidsrecht. Zo had Goudsmit vooral een besruursrechtelijke invulling van het gezondheidsrecht voor ogen gehad. In tegenstelling tot bijvoorbeeld Leenen, Rang, Van der Mijn die her breder wilden trekken door ook her straf-en civielrechr 
in beschouwing te nemen. De laatste visie lijkt het gewonnen te hebben ten opzichte van de eerste, eind jaren zeventig stelde Leenen dat het gezondheidsrecht zich zowel op civielrechtelijk, strafrechrelijk als administratiefrechtelijk gebied bewoog. Mer andere woorden, het zou een 'horizontaal specialisme' zijn (Leenen 1979: II4).

is De arts en ethicus Dillmann ziet een ander verschil tussen ethici en juristen: 'Het valt mij op dat juristen en ethici (en medici zijn op dit opzicht bij de ethici te rubriceren) ook systematisch anders omspringen met casuïstiek. De jurist toetst de casus aan de regel, heeft oog voor precedenten en precedentwerking. De arts en ethicus kijken naar de individuele aspecten van de casus, de contexr, de deugdzaamheid van de actoren en naar de mogelijkheden ten goede' (Dillmann \& Roscam Abbing 1997: 289).

Onder 'ethiek van de gezondheidszorg' verstond Sporken: 'de beschrijving en analyse van gezondheidszorg in haar verschillende aspecten en de daarin voorhanden zijnde of voorgestelde ethische normen, de verheldering van het mens- en maarschappijbeeld die aan deze normen ten grondslag liggen en zich daarin manifesteren en de kritische toetsing van deze achtergrondvisie op haar humaniteitskarakter' (p. 62).

17 'Kenmerk van alle codes is dat steeds sprake is van één actor, één persoon die handelt en verantwoordelijk is. Medisch-ethische problemen worden beschouwd als problemen van de arts: zijn beslissing, en de zorgvuldigheid waarmee die genomen wordt staat centraal. Uiteraard is de zorgvuldigheid gericht op het welzijn en belang van de pariënt, maar die blijft als persoon nog op de achtergrond. Dat verandert snel in de jaren zestig van deze eeuw, niet alleen in Nederland, maar ook daarbuiten (Dupuis 1988: 25).

18 Ten eerste zouden excessen op het terrein van experimenten met mensen (tijdens de oorlog), ertoe hebben geleid dat het idee van zelfregulering door artsen aanzienlijk aan vertrouwen had ingeboet. Het belang van de patiënt werd bij deze onderzoeken ondergeschikt gemaakt aan het zoeken naar nieuwe kennis. Ten tweede zou de ontwikkeling en toepassing van nieuwe medische technologie voor een verandering in de medische ethiek hebben gezorgd. Mer de technologie zou de medische macht zijn vergroot, waardoor er extra behoefte was aan bezinning op een zinvolle toepassing van de technologie. Ten derde worden demografische ontwikkelingen genoemd als oorzaak voor veranderingen in de medische ethiek. Vergrijzing en schaarste en ethische vragen hierover zouden hand in hand gaan. Bijvoorbeeld de vraag of leeftijd een rol zou mogen spelen bij de verdeling van schaarse middelen. Ten vierde wordt er gewezen op maarschappelijke veranderingen. De grote groei van de gezondheidszorg (voorzieningen, regelingen, wetten, organen en instellingen) zou tor ethische vragen hebben geleid. Ten slotte worden ook veranderingen in het denken over ethiek zelf als oorzaak genoemd. Het denken over medische macht en paternalisme zou ook tot een groeiende belangstelling voor de ethiek hebben geleid (Ten Have \& Ter Meulen et al. 1998: 36 e.v.).

I9 Deze kritische geluiden uit Nijmegen waren gebundeld in het CEKUN (zie vorige paragraaf).

20 Empirisch-ethisch onderzoek heeft onder andere in het Nwo-programma 'Ethiek en Beleid' vorm gekregen. Dit programma is een voorbeeld van empirische studies naar ethische problemen. Het onderzoek is in 1995 van start gegaan en probeert aan 
de behoefte om meer vanuit praktijkervaringen tor ethische theoricvorming te komen te voldoen.

2I Met deze term duidde De Vries in een krantenartikel her soort cthici aan regen wie hij zijn kritiek richtte (De Vries 1993b).

22 In hoeverre is het nodig of gewenst de eerste te codificeren in positieve rechtsregels, opdat via wetten, de respectievelijke verantwoordelijkheden van patiënt, arts of [...] geurgeerd worden' (Mertens \& Stolte 1958: 217).

23 'Bovendien lijkt het erop dat moraal en ethiek niet alleen worden geïnstitutionaliseerd, maar ook gejuridiseerd. Er zou dus sprake kunnen zijn van een juridisering van moraal en ethiek. De morele oordeelsvorming en de ethische reflectie krijgen niet alleen een quasi-juridisch gezag, maar ook zelf een - althans op het eerste gezicht - meer op het recht lijkende structuur. [...]. In de ethische reflectie wordt veel verwezen naar "de beginselen van de medische ethiek" alsof dit een vaststaand kwartet van beginselen is met een duidelijke inhoud. Dit heeft zeker te maken met het feit dat de ethische reflectie zich mede richt op concreet beleid en wetgeving, waardoor voor filosofische nuancering - althans in de presentatie aan het bredere publiek - weinig ruimte meer is' (p. 4).

24 In her katholieke artsenblad Metamedica was tien jaar eerder al een serie over echiek en recht in de gezondheidszorg verschenen. In deze serie werd door de auteurs gesteld dat ethiek en recht niet zonder elkaar zouden kunnen, maar wel degelijk verschilden. De conclusie luidde dat enerzijds ethiek verder zou gaan dan het recht in de zin dat ze normen en waarden ter discussie stelt, anderzijds zou het recht juist verder gaan dan de ethiek, omdat het recht een juridisch bindende en afdwingbare norm kan formuleren (Ten Have $\&$ Vroom-Kastelein 1987). De serie besloot met de stelling dat zowel ethiek als recht in ieder geval zouden moeten helpen om vragen, die door de geneeskunde worden opgeworpen, te beantwoorden op een wetenschappelijk gefundeerde wijze. Met andere woorden, ethiek en recht als coöperatieve partners in het complexe veld van de geneeskunde. Dat gaat nog één stap verder dan een eventueel harmonieuze relarie, waarbij elk zijn eigen terrein heeft.

\section{Noten bij hoofdstuk 3}

I Dit hoofdstuk richt zich op een variant van zijn uitgebreide theoretische model. De medische professie wordt als een relatieve constante in het geheel beschouwd, door geen expliciete aandacht eraan te besteden. Deze keuze vloeit voort uit de onderzoeksvraag.

2 De verdeling van zeggenschap komt niet overeen met het simpelweg verdelen van taartpunten, maar moet meer als een kwalitatieve verdeling beschouwd worden. Verantwoordelijkheden verschuiven, er raken meer mensen bij betrokken waarbij de stem van de één zwaarder kan tellen dan van de ander. Dit kan per periode weer verschillen.

3 In Nederland stamt het eerste geschrift over euthanasie - 'het zalig sterven in den Here' - waarschijnlijk uit 165I (Hoornbeeck I651). 
Wackers (1994) laat zien dat de definitie van hersendood in Nederland zeer nauw verbonden is met de praktijk van orgaantransplantatie en reanimatietechnieken. Hij benadrukt dat het criterium van hersendood wel stabiel lijkt, maar dat nieuwe ontwikkelingen, zoals bijvoorbeeld 'genetic engineering', mogelijk opnieuw een wijziging zouden kunnen betekenen.

5 Tijdens een congres voor anesthesisten in 1957 is het probleem van de reanimatie ook aan de orde gekomen. Belangrijk voor de gedachteontwikkeling in deze kwestie is waarschijnlijk het antwoord van Paus Pius XIr. Hij stelde dat het staken van een reanimatie indirect doden is en in sommige gevallen geoorloofd zou kunnen zijn (Paus Pius XII 1957).

6 De term 'euthanasie' verwijst hier impliciet naar artikel 293 van het Wetboek van Strafrecht.

7 Samen met Enschedé zou Langemeijer in de jaren tachtig pleiten voor het idee van de medische exceptie als oplossing voor de regulering van het euthanasievraagstuk. De betekenis van dit voorstel en de argumentatie van Enschedé worden in hoofdstuk vijf verder uitgediept, omdat daar het thema van de normering en regulering van levensbeëindigend handelen aan de orde is.

8 Hierop reageerde de secretaris van het Medisch Tuchtcollege in Amsterdam. Hij pleitte ervoor om het leven te allen tijde in stand te houden (Catz 1960). Catz vreesde dat anders het einde zoek dreigde te raken. Waar ligt namelijk de grens, zo vroeg hij zich af. Bovendien kon een arts door zijn handelen, onvoldoende handelen of helemáál niet handelen zich schuldig maken aan artikel I van de medische tuchtwet, namelijk 'het vertrouwen in de stand der geneeskundigen ondermijnen'.

9 Door de mogelijkheid van (hart)transplantatie kreeg van vraag naar sterven en dood een nog dwingender karakter. Sporken, hoogleraar theologie en de randproblemen van de ethiek en medische ethiek aan het Theologisch Instituut in Eindhoven, benadrukte dat niet alle organen tegelijkertijd sterven. Dit riep volgens hem vragen op als: welke organen van het menselijk organisme moeten intact zijn om te kunnen spreken van een levend mens? (Sporken 1968).

10 De arts-patiëntrelatie komt in het hoofdstuk over zelfbeschikking en autonomie, hoofdstuk vier, nader aan de orde.

II Ook bij het katholieke artsenblad Metamedica hielden de veranderingen in de medische ethiek de gemoederen bezig. In 1970 werd er een speciale editie aan gewijd (Tellegen 1970; Roelink 1970; Sporken 1970b; Lindeboom 1970). Later werd de vraag opgeworpen of er nog wel van medische ethiek kon worden gesproken of dat de aanduidingen hiervoor te divers waren (Wellen 1971; Sporken 1971; Sporken 1972b).

I2 Door de vorming van de nieuwe werkgroep werd de permanente Commissie Medische Ethiek en Beroepsgeheim (die in 1964 was samengevoegd uit de Commissie Beroepsgeheim en de Commissie Medische Ethiek) opgeheven. Deze Commissie (bestaande uit artsen en één jurist) had de opdracht gekregen een nieuwe uitgave van Medische Gedragsleer (het zogenaamde Blauwe boekje uit 1959) te realiseren. In 1970 geeft de commissie echter aan dat 'zij de hoop heeft opgegeven een Medische Ethiek te kunnen samenstellen'. Een teken dat de crisis in volle omvang aanwezig is. Op 29 oktober 1970 wordt de nieuwe stuurgroep Medische Ethiek 
ingesteld, waarin ook een jurist, moraaltheoloog en socioloog zitting in hebben (Roelink 1971).

13 Tijdens een vergadering in maart 1972 besloor het hoofdbestuur van de KNMG om een (alleen uit artsen bestaande) Werkgroep Euthanasie in te stellen. De opdracht luidde overwegingen te formuleren ten aanzien van euthanasie, met bijzondere aandacht voor de positie van de arts en de patiënt (Commentaar 1975).

I4 De werkgroep koos voor de volgende werkdefinitie: Euthanasie is het opzettelijk nalaten het leven van een patiënt te verlengen, het opzettelijk verkorten of beëindigen van het leven van een patiënt, dit alles uitsluitend in het belang van de patiënt (p. 8). De werkgroep concludeerde dat er een wezenlijk verschil bestond tussen actieve en passieve euchanasie; 'een wezenlijk verschil tussen beide "middelen", en dus tussen de te nemen beslissingen, is echter dar in het laatste geval [actieve euthanasic] de afloop vaststaat en in het eerste niec' (idem p. 9).

Is Vanuit huidig inzichr schreef Van Till iers merkwaardigs over de relatie tussen recht en ethiek. 'De regenstelling tussen al dan niet geschreven verplichtingen van medische ethiek enerzijds, en de ongeschreven juridische verplichtingen anderzijds, is er dan ook niet, in afwijking van wat aan medische zijde vaak wordt gedacht of voorgesteld' (p. 37).

16 In dit advies ging het over cuthanasie in algemene zin. Het probleem van euthanasie bij pasgeborenen werd in her advies zijdelings behandeld. Vandaar dat de Gezondheidsraad in 1975, vanwege de specifieke problemen bij dic onderwerp, hier een speciaal interim-advies aan wijdde. In dat tweede interimadvies werden de richtlijnen uit het eerste advies toegepast op euthanasie bij zwaar defecte pasgeborenen (Gezondheidsraad 1975).

I7 In een commentaar op het advies van de Gezondheidsraad bestreed de jurist Rood dit onderscheid tussen recht en ethiek. Hij stelde dat het recht eveneens sociaalcultureel bepaald was en ook veranderde, zij het geleidelijker dan de ethiek (Rood 1973).

18 Fiuthanasie werd gedefinieerd als: Euthanasie is een opzettelijk levensverkortend handelen of een opzettelijk nalaten van levensverlengend handelen bij een ongeneeslijke patiënt in diens belang. (Bij handelen wordt in dit verband uitsluitend gedacht aan handelen door een medicus of onder diens directe verantwoordelijkheid.) (Gezondheidsraad 1972: 284).

I9 Rang was ook lid van de Commissie Medische Ethiek (zowel het eerste advies als het tweede) van de Gezondheidsraad.

20 Dit vonnis was de tweede keer dat in Nederland art. 293 en 294 van het Wetboek van Strafrecht toegepast werden. De eerste keer was in 1952 toen iemand (ook arts) zijn broer middelen had verstrekt tot beëindiging van zijn leven (rechrbank van Utrecht).

2I Naast deze inspecteur heeft ook de jurist Leenen op dit punt een niet onbelangrijke rol gespeeld. 'Ik ben erbij betrokken geweest. En de inspecteur ook... Die inspecteur die zat daarmee. Hoe moeten we dit varkentje wassen? Die had wat ideetjes. Ik had ook wat ideerjes. Ik had wat algemene benaderingen en ik had wat gevallen meegemaakr. Hij heeft die dingen opgeschreven, ik niet. Hij was getuige-deskundige en ik was adviseur' (interview Leenen). 
22 Die omstandigheden zouden zijn:

- als het gaat om een ongeneeslijke ziekte;

- als het lijden voor een patiënt subjectief ondragelijk is;

- als de patiënt vooraf te kennen geeft uit zijn lijden verlost te willen worden;

- als de stervensperiode is ingegaan of zich heeft aangekondigd;

- als de ingreep door de behandelend arts of de in consult geroepen specialist, dan wel een arts in overleg met de behandelend arts, plaatsvindt (Rood 1973: 123).

23 Mevrouw Postma is uiteindelijk tot een week gevangenisstraf veroordeeld. De straf is overigens niet tenuitvoergelegd (Indewey Gerlings-Huurman 1977).

24 Dat zijn: het staken van een zinloze medische behandeling, 'euthanasie' bij pasgeborenen, indirecte 'euthanasie', het stoppen van de verzorging van een hersendode, weigering van medische behandeling en noodtoestand bij gebrek aan middelen (Leenen 1978: 238).

25 De кNмG had namelijk nog geen uitdrukkelijk standpunt ingenomen ten aanzien van euthanasie. De betreffende KNMG-commissie is sterk te rade gegaan bij Leenens hoofdstuk over euthanasie in zijn handboek (1978), met name op het punt van de definitie en het omschrijven van de begrippen. Daarnaast was Leenen zelf vicevoorzitter in de Staatscommissie en had daar een centrale rol, 'want ik was de enige die wat van de theorie afwist, ik gaf dus heel vaak college, hoe het zat en met de definitie. En dat zie je ook allemaal in dat rapport weer terug, van de Staatscommissie' (interview Leenen).

26 Klijn was ook lid van de Staatscommissie. Samen met de jurist Nieboer heeft hij een minderheidsnota geschreven bij het rapport van de Staatscommissie (Staatscommissie 1985: 191 e.v.).

27 Deze commissie was ingesteld, omdat tijdens her regeerakkoord van 1989 de gedachte leefde dat er geen werkelijk inzicht was in de omvang en de aard van de medische euthanasiepraktijk. Het rapport van de commilssie zou voldoende materiaal moeten opleveren om de politieke impasse rond euthanasie te doorbreken. Zie verder hoofdstuk vijf.

28 Uit het hoofdredactionele commentaar van het Tijdschrift voor Genéeskunde werd duidelijk dat sommigen niet euthanasie op verzoek, maar 'het doden uit barmhartigheid ("mercy killing") zònder verzoek van de betrokkene' zelfs als her 'morele probleem bij uitstek' bestempelden (Redactioneel 1992).

29 Deze commissie heeft er twaalf jaar over gedaan om tot een standpunt te komen. In die periode hebben drie ethici en één jurist deel uitgemaakt van deze commissie.

\section{Noten bij hoofdstuk 4}

r Een beschrijving van de opkomst van de 'mondige patiënt', in de context van de huisartsgeneeskunde en de geestelijke gezondheidszorg, is in het proefschrift van Mol en Van Lieshout (hoofdstuk 6) te vinden (Mol \& Van Lieshout 1989).

2 Her begrip denkstijl is ontleend aan een model voor wetenschapsontwikkeling van Ludwig Fleck. Her begrip paradigma komt uit her werk van Thomas Kuhn en is eer- 
der gebruikt om ontwikkelingen op het terrein van de geneeskunde, ethiek en recht te beschrijven (Verbrugh 1978; Van Es 1978; Wolf 1994).

3 Zie ondermeer: (Stolte 1960; Schuurmans Stekhoven 1969 b).

4 Zie 'Afzien van of ophouden met medische behandeling?' in hoofdstuk drie.

5 Zie 'Zeggenschap over medisch-ethische vragen' in hoofdstuk drie.

6 De medische macht is hier niet alleen de medisch-technische macht zoals die in het vorige hoofdstuk aan de orde is gekomen, maar juist en vooral de medische beslissingsmacht die aan de medisch-technische macht is gekoppeld.

7 'Alle dingen behoren u toe... hetzij wereld, leven of dood, hetzij heden of toekomst, alle dingen behoren $U$ toe, maar gij zijt van Christus en Christus van God' (Heering 1977: 21).

8 Zie ook hoofdstuk drie over herziening takenpakket artsen door Prick (Prick ig69b).

9 Zie 'Actieve en passieve euthanasie' hoofdstuk drie.

10 Omdat er nog geen consensus was over een definitie van euthanasie, kon deze claim uiteraard alleen tegen de achtergrond van Leenens eigen definitie worden gezien. Zijn definitie luidde: een opzettelijk levensverkortend handelen (inclusief nalaten) door een ander dan de betrokkene op diens verzoek (Leenen 1978: 213).

II Dat wil zeggen dat er een 'redelijke verhouding tussen middel en effect' moet zijn (Leenen 1978: 239).

I2 De ethicus De Graaf verwijst expliciet naar Leenen als hij het idee van zelfbeschikking wil legitimeren. Hij voegt er echter aan toe dat dit zijns inziens morele recht niet absoluut opgevat kan worden (De Graaf 1985: 6).

I3 Klijn heeft samen met de jurist Nieboer een minderheidsnota geschreven bij het rapport van de Staatscommissie. Daardoor is de Staatscommissie niet tot een eensluidend advies kunnen komen (Staatscommissie 1985: r9r e.v.).

14 Een ander buitenstaanderperspectief vanuit juridische hoek, was bij de hoogleraar rechtssociologie Griffiths te vinden. Deze jurist uitte geen inhoudelijke kritiek op het zelfbeschikkingsrecht, maar meende juist dat de discussie over euthanasie veel minder van het idee van zelfbeschikking uirging dan algemeen werd verondersteld. Hij stelde dar de wetrelijke regulering van euthanasie eind jaren tachtig meer door de overheid dan door het zelfbeschikkingsrecht werd bepaald. Van een juridische benadering van het euthanasievraagstuk vanuit het zelfbeschikkingsrecht was volgens Griffiths slechts sporadisch sprake in de discussie over euthanasie (Griffiths 1987: 690). Griffiths noemde Leenen als positieve uitzondering.

15 De psychiater Chabot was vervolgd voor het geven van hulp bij zelfdoding in 1991 aan een 5o-jarige vrouw die het leven, na het overlijden van haar twee zoons, ondraaglijk vond.

16 De zogenoemde zorgvuldigheidseisen komen in het volgende hoofdstuk uitgebreid aan de orde.

I7 De vraag wanneer er sprake is van medisch zinvol of medisch zinloos handelen is volgens Leenen te beantwoorden aan de hand van medisch-objectieve criteria, dit maakt het dan ook tot een medisch-professioneel oordeel. 'De arts is slechrs bevoegd tot handelen, indien dat zinnig is en waar zijn handelen zinloos wordt, ein- 
digt zijn bevoegdheid tor dat handelen en gaat dit over in mishandelen' (Leenen 1978: 239). Het argument van medisch zinloos handelen is uiteraard niet exclusief voor de discussie over levensbeëindigend handelen, het speelt bijvoorbeeld ook een rol in de discussie over schaarste in de zorg.

I8 Niet alleen de KNMG worstelde met de problematiek. In 1992 verscheen er een rapport van de Nederlandse Vereniging voor Kindergeneeskunde waarin her criterium van 'leefbaar leven' centraal stond bij de bepaling of een behandeling bij een pasgeborene ingezet moet worden of niet. Aandachtspunten hierbij waren: communicarie, zelfredzaamheid, afhankelijkheid van het medisch circuit, lijden en de te verwachten levensduur (NVvK 1992). In het rapport van de Gezondheidsraad over onderhavige problematiek werd onderscheid gemaakt tussen een eerste- en een derdepersoonsperspectief; vroegere wilsuitingen van de pariënt en 'wat de pariënr gewild zou hebben' (Delden 1991). Bij beide perspectieven stond her weldoen centraal.

I9 Volgens Leenen was 'kwaliteic van leven [is] niet te operationaliseren en de mechoden, gericht op meten, zijn niet geëigend' (Leenen 1985). 'Aan de orde is de vraag of kwaliteit van leven als zelfstandige norm - (...) - voor levensbeëindiging zonder verzoek moet worden erkend. Die vraag beantwoord ik ontkennend' (Leenen 1989a: 23I).

20 Gevers becommentarieerde alleen de rapporten van de KNMG.

2I Den Hartogh richtte zijn kritiek op de CAL-rapporten en het rapport over NonTreatment Decisions bij meerderjarige wilsonbekwamen van de Gezondheidsraad (Dillmann \& Legemaate et al. 1997; Delden 1991).

$22 \mathrm{Hij}$ stelde dat 'het recht, als het van geen levensbeëindiging van wilsonbekwame pasgeborenen wil weten, beginnen moet met her "non treatment" te verbieden, want op dat punt beslissen artsen of een kindje zal sterven of niet' (Kuitert 1989).

23 Deze en soortgelijke kritiek staat meer uitgebreid in hoofdstuk twee beschreven.

24 Zie hoofdstuk twee bijvoorbeeld in De Siamese tweeling(Van der Burg \& Ippel 1994).

25 Zie hoofdstuk twee.

26 Zie ook 'Actieve en passieve euthanasie' hoofdstuk drie.

27 Zie bijvoorbeeld in Reinders 1994.

\section{Noten bij hoofdstuk 5}

1 De zorgvuldigheidseisen voor euthanasie verwijzen naar een pakket van eisen waaraan een arts moet voldoen bij de toepassing van euthanasie. Er moet onder andere sprake zijn van: een vrijwillig en weloverwogen verzoek van de patiënt, ondraaglijk en uitzichtloos lijden, het ontbreken van alternatieve behandelingsmogelijkheden en consultatie van een andere arts. Sinds I april 2002 zijn de zorgvuldigheidseisen opgenomen in de wet levensbeëindiging op verzoek en hulp bij zelfdoding.

2 De term 'zwarte doos' is door de wetenschapsantropoloog Latour gebruikt om het werk en de complexiteit, die bijvoorbeeld met de ontwikkeling van computers gepaard is gaan, aan te duiden. Bij ons gebruik van de computer is namelijk de strijd in de ontwikkeling ervan, de complexe werking en het commerciële netwerk om de computer in stand te houden, inmiddels aan ons oog onttrokken. We kijken alleen 
nog maar naar de programma's die we er in stoppen, de input, en de data die eruit komen, de output. Om al het werk, dat is verzet om de computer zo te kunnen gebruiken zichtbaar te maken, moet de zwarte doos ervan worden geopend. In dit hoofdstuk wordt dat voor de zorgvuldigheidseisen gedaan. De input bij de zorgvuldigheidseisen zijn de gegevens uit onder andere het dossier van de patiënt en de output is het oordeel van de toetsingscommissie of de arts al dan niet zorgvuldig heeft gehandeld. De manier waarop bij de zorgvuldigheidseisen gegevensverwerking, normering, regulering en toersing met elkaar verbonden zijn geraakt en werkbaar zijn gemaakt is inmiddels niet meer bekend.

3 De Amerikaanse cultuur-historicus Kennedy eindigt zijn historische analyse van het Nederlandse euthanasiedebat in zijn boek Een weloverwogen dood halverwege de jaren tachtig. Hij beargumenteert dit met de stelling dat op dat moment euthanasie in Nederland bespreekbaar was geworden en de huidige toepassing van het euthanasiebeleid gestoeld is op de praktijk van de jaren tachtig. Dit hoofdstuk laat echter zien dat er nog veel werk nodig was en blijft om de normen en regels tot een functionerend netwerk om te vormen.

4 Uiteraard hebben ook anderen, onder andere artsen en verpleegkundigen, hieraan meegewerkt. In het kader van de probleemstelling van het onderzoek gaat de aandacht echter voornamelijk uit naar het werk van ethici en juristen.

5 De inzet van het gebruik van de actor-netwerktheorie in dit hoofdstuk is tweeledig: hoe wordt iets 'hard' of 'stabiel' (normen voor het toepassen van euthanasie door de medische professie) en wat betekent deze hardheid voor de praktijk (andere ontwikkelingen, bijvoorbeeld de pil van Drion worden hierdoor beperkt)? De symmetrieeis in Latour's actor-netwerktheorie, evenveel aandacht voor mensen en dingen, wordt enigszins doorbroken. De meeste aandacht gaat namelijk uit naar teksten waarin relatief minder aandacht wordt besteed aan de manier waarop apparaten en machines bijdragen aan de vorming van een normatieve orde.

6 Het bestuderen van teksten is volgens de actor-netwerktheorie van Latour een goede manier om een debat of controverse te analyseren. In zijn actor-netwerkanalyse van de controverse rond baby Ross heeft de wetenschapsonderzoeker Hendriks, door het bestuderen van teksten, laten zien hoe een normatieve orde voor de neonatologiepraktijk is geconstrueerd (Hendriks 1992). In dit hoofdstuk wordt de analyse van de normatieve orde rond levensbeëindigend handelen beperkt tot de vraag hoe de zorgvuldigheidseisen zijn ontstaan en hoe ze functioneren.

7 Deze commissie bestond uit vijf juristen (o.a. Van Till, Leenen en Rang), één moraaltheoloog (Beemer), negen artsen, één verpleegkundige en één socioloog.

8 Dit was met name ingegeven door de snelle veranderingen in de medische (en ethische) context en de rolopvarting van de overheid.

9 De Gezondheidsraad stelde dat het onder bepaalde omstandigheden voor een arts 'in medisch-ethisch opzicht geoorloofd' was 'de ter beschikking staande medische mogelijkheden niet of niet meer aan te wenden met de bedoeling menselijk leven (...) te beëindigen' (p. 30). Als voorbeeld van mogelijke levensbeëindiging werd de patiënt die een (subjectief) ondraaglijk lijden onderging, dat niet te verlichten was en waarvan ook de oorzaak niet kon worden weggenomen, genoemd. 
Io Naast deze inspecteur heeft ook de jurist Leenen op dit punt een betekenisvolle rol gespeeld. Tussen hem en de geneeskundig inspecreur was hierover intensief contacr geweest (interview Leenen, 11 oktober 1999).

II Het verschil zat in de vierde voonwaarde. Deze werd door de rechtbank verruimd. Ze stelde dar het ook kon gaan om patiënten buiten de stervensfase, omdat daar ook sprake van ondragelijk en uitzichtloos lijden zou kunnen zijn.

I2 Er werden vraagtekens geplaatst bij de rol van de geneeskundig inspecteur en diens rapportage. Tevens werd het oordeel van de 'gemiddelde medicus' of 'de brede medische kring in Nederland' als criterium en de invulling ervan ter discussie gesteld (Ekelmans 1973; Rasker 1974). Enerzijds waren de voorwaarden die werden gehanteerd bij de rechtszaak in Leeuwarden 'nieuw'. Anderzijds werden ze aangehaald als het gedachtegoed van de gemiddelde medicus in Nederland, zonder dat hierover expliciet overleg met de KNMG was gevoerd.

I3 De KNMG hanteerde als 'werkdefinitie': euthanasie is het opzettelijk nalaten het leven van een patiënt te verlengen, het opzettelijk verkorten of beëindigen van het leven van een patiënt, dit alles uitsluitend in her belang van de patiënt (KNMG 1975: 8).

I4 'De "kunst om te genezen" laat zich niet zo gemakkelijk rijmen met de bekorting van het leven. Deze is een zaak die veeleer diepliggende sociale aspecten heeft, cultureel-sociale aspecten en bovenal echische' (Buijs 1979: 374).

15 Thans is geregeld dat een principieel weigerende arts naar een andere arts moet doorverwijzen.

I6 De rechtbank concludeerde overigens dar Mw. Wertheim nier aan de gestelde voorwaarden had voldaan.

17 Zo werd in beide rechtszaken vereist dat de betrokkene lichamelijk of psychisch ondragelijk moest lijden en dat er een verzoek om levensbeëindiging was van de betrokkene. Maar ten aanzien van de rol van de arts werd in Leeuwarden gesteld dat de levensbeëindiging in handen moest blijven van de arts, terwijl in Rotterdam werd gesteld dat er een arts bij betrokken moest zijn. Daarnaast mochten er geen andere redelijke oplossingen bestaan volgens Rotterdam en mocht er ook geen onnodig leed aan anderen worden toegebracht. Deze laatste eis was overgenomen uit de brochures van de NVVE en de SVE.

I8 Ten eerste spelen ziekte en lijden vaak een rol en om daarover te oordelen was deskundigheid nodig (Leenen refereerde aan de zaak Wertheim waarin de betrokkene in de veronderstelling was aan kanker te lijden, terwijl bij sectie hiervoor geen aanwijzingen werden gevonden). Ten tweede werd in Rotterdam gesteld dat alle alternatieve mogelijkheden moesten zijn verkend, daartoe behoort ook de pijnbestrijding. Ook hiervoor was volgens Leenen medische kennis vereist. Ten derde moest de arts ervoor zorgen dat de levensbeëindiging geschiedde 'volgens de regelen der kunst'. Bovendien zag Leenen een moeilijkheid ten aanzien van de vraag hoe verantwoordelijkheden tuchtrechtelijk gezien moesten worden geregeld indien een arts wel betrokken was, maar er geen deskundige hulp was gegeven. Tenslotte zou her in het kader van de maatschappelijke regulering en controle volgens Leenen veel gemakkelijker zijn als het verlenen van hulp bij levensbeëindiging in handen lag van een omgeschreven, beperkte groep. Bij deze beperkte groep, artsen, was er namelijk 
een extra correctiemogelijkheid via het medisch tuchtrecht. Met deze gedetailleerde vergelijking van de twee rechtszaken bouwde Leenen dus mee aan de vorm waarin er bij beide rechtszaken een normatief kader tot stand was gekomen; hij was daarmee productief.

19 Het Openbaar Ministerie baseerde op deze voorwaarden haar sepotbeleid, waardoor het mogelijk was om in gevallen waarin een langdurige en ernstig lijdende patiënt, na voldoende en correct begrepen informatie en afweging daarvan, aan artsen om hulp vroeg voor een goede dood, deze hulp gegeven kon worden. Naast de veranderende medische ethiek zag zij ook in de oprichting van her Instituut voor Gezondheidsethiek in Maastricht (opgericht I januari 1984) een reden om een reeks artikelen over medische ethiek te publiceren (Stuyt \& Van Es 1984: 1232). Een kamerlid had eind jaren zeventig het vraagstuk van euthanasie aan de orde gesteld, door te wijzen op een aanbeveling van de Raad van Europa (Gezondheidsraad 1982). In een motie was voorgesteld om een staatscommissie in te stellen voor een advies over het toekomstige overheidsbeleid rond euthanasie. Een rapport van de Staatscommissie is in 1985 gepubliceerd.

$22 \mathrm{Na}$ het reproduceren van de voorwaarden: vrijwilligheid, weloverwogen verzoek, duurzaam verlangen naar de dood en onaanvaardbaar lijden, voegde de KNMG er ook aan toe dar de arts die met een verzoek om euthanasie werd geconfronteerd overleg zou plegen met een 'ervaren collega' (p. 994). Bovendien werd gesteld dat euthanasie in de arts-patiëntrelatie thuishoorde, omdat 'de arts als enige de voor besluitvorming zo cruciale vraag kan beantwoorden wat de patiënt precies mankeert, welke reële hoop op verbetering gekoesterd mag worden c.q. welke lijdensweg naar alle waarschijnlijkheid nog zal worden afgelegd' (p. 993).

23 Her was onder artsen kennelijk een gezaghebbend rapport. Interview Cor Spreeuwenberg, 8 juli 1999 .

24 Strafuitsluitingsgronden vallen uiteen in twee categorieën: rechtvaardigingsgronden en schulduitsluitingsgronden. Rechtvaardigingsgronden rechrvaardigen een strafbaar feit, waardoor dit feit niet langer strafbaar is. Bijvoorbeeld bij euthanasie: het ontbreken van wederrechrelijkheid, de medische exceptie en overmacht in de zin van noodtoestand. Schulduitsluitingsgronden maken dat de dader niet strafbaar is, omdat zijn schuld ontbreekt. Bijvoorbeeld bij euthanasie: overmacht in de zin van gewetensdrang, en afwezigheid van alle schuld in de vorm van rechrsdwaling.

25 Het vorige hoofdstuk heeft laten zien hoe dit concept halverwege de jaren tachrig dominant was geworden in het denken over medische ethiek.

26 Deze drie bijzondere voorwaarden zijn: $\mathrm{I}$. De beslissing om hulp te verlenen mag niet door één persoon worden genomen; 2. Bij de beslissing om hulp te verlenen moet altijd een arts betrokken zijn die het middel voorschrijft; 3 . Er dient collegiaal overleg te zijn, indien de stervensfase is aangebroken, of, wanneer er nog niet van een stervensfase sprake is, behoort nog een andere deskundige (psychiater, psycholoog of sociaal werker) te worden geraadpleegd. Aan deze laatste voorwaarde had Schoonheim niet voldaan, hij had 'slechts' overleg gepleegd met zijn arts-assistent en niet met een met een onafhankelijke, niet behandelende arts (bijvoorbeeld een psychiater) (Scholten 1983). 
27 Twee artsen, Rasker en Van Hellemondt (beiden bestuurslid van de sve), stelden in een reactie hierop dat de Rotterdamse voorwaarden als een juridische formulering beschouwd konden worden van wat reeds lang in brede medische en ethische kring toelaatbaar werd geachr (Rasker \& Van Hellemondt 1984).

28 Of er sprake was van een conflict van plichten, was afhankelijk van het (objectieve) medische inzicht. Dat medisch inzicht was op zijn beurt weer afhankelijk van de heersende medisch-ethische normen en daar bestond grote onzekerheid over.

29 Het wetsvoorstel beperkte zich tot euthanasie (als levensbeëindiging op verzoek onder strikte voorwaarden) en hield een grondige herziening in van de artikelen 293 en 294 Sr. In het wetsvoorstel werd voorzien in een uitzonderingspositie voor artsen die op zorgvuldige wijze euthanasie zouden toepassen of hulp bij zelfdoding verlenen aan iemand die zich in de stervensfase bevond, of bij wie sprake was van ondraaglijk lijden dan wel als ondraaglijk lijden ervaren lichamelijk of geestelijk lijden. De Raad van State heeft uiteindelijk negatief gereageerd op het voorstel. In de Tweede Kamer is wel uitvoerig over het voorstel gediscussieerd.

30 'Kortom: sedert $188 \mathrm{I}$ is de arts die euthanasie toepast tegen de straffende macht van de overheid beschermd mits hij gebleven is binnen de regels van de medischethische standaard' (Enschedé 1985: 9).

31 Leenen was lid en vice-voorzitter van de Staatscommissie. In een recensie op het genoemde boek van Enschedé verduidelijkte Leenen zijn kritiek op de 'medische exceptie' als oplossing voor het euthanasievraagstuk : 'De zwakke stee in de redenering van de auteur is, dat niet wordt onderscheiden tussen normaal medisch handelen conform de medisch professionele standaard en handelen van artsen dat door andere normen wordt beheerst. (...). De veranderingen in opvattingen op deze terreinen [abortus en euthanasie] zijn ook niet binnen de medische professie tot stand gekomen - integendeel die professie volgde maatschappelijke verandering, veeleer schoorvoetend -, maar in de bevolking. Omdat bij de uitvoering van die handelingen veelal een arts is betrokken worden abortus en euthanasie abusievelijk wel als normaal medisch handelen aangeduid' (Leenen 1986).

32 Enschedé stelde daarentegen dat Leenen een fout maakte door te veronderstellen dat er in het Wetboek van Strafrecht verboden en geboden staan. Enschedé stelde juist dat in de artikelen 293 en 294 slechts richtsnoeren voor het gedrag van de rechter te vinden zouden zijn, en - anders dan Leenen veronderstelde - geen aan de artsen geadresseerde normen (Enschedé 1986). Tevens verweet hij de Staatscommissie dat zij het euthanasievraagstuk als een strafrechtelijk vraagstuk had opgevar, in plaats van als een 'privaatrechtelijk deel van het gezondheidsrecht'.

33 De Staatscommissie Euthanasie was op 18 oktober 1982 ingesteld.

34 Twee leden van de commissie, Klijn (ethicus) en Nieboer (jurist), konden zich echter niet vinden in een deel van het rapport en schrijven een minderheidsnota.

35 Zodat 'het opzettelijk beëindigen van het leven van een ander op diens uitdrukkelijk en ernstig verlangen niet langer strafbaar is, indien die geschiedt door een geneeskundige in het kader van zorgvuldig medisch handelen ten aanzien van een patiënt die in een uitzichtloze noodsituatie verkeert' (Staarscommissie 1985: 124). 
36 De commissie van de Gezondheidsraad die dit advies had voorbereid bestond voor het merendeel uit artsen. Vanuit het gezondheidsrecht zat H. Roscam Abbing, hoogleraar gezondheidsrecht, en vanuit de ethiek E. Schroten, hoogleraar christelijke echiek, in de commissie.

37 Niertemin stond nog steeds open wáár de geformuleerde zorgvuldigheidseisen precies hun beslag zouden moeten vinden. Daarover bestond tussen de verschillende wetsvoorstellen verschil van mening. Wat betreft de zorgvuldigheidseisen was er een verschil tussen het regeringsvoorstel en het initiatief-wetsvoorstel Kohnstamm. In her initiacief-wetsvoorstel zouden de zorgvuldigheidseisen in het Wetboek van Strafrecht moeten worden opgenomen en bij het regeringsvoorstel in de Wet Uitoefening Geneeskunst. Leenen heeft kritiek geuit op de laatste constructie. Zo vond hij her een 'juridisch merkwaardige constructie om voor een zo individuele situatie als een conflict van plichten wettelijke zorgvuldigheidseisen vast te stellen' (Leenen I988a: 1704). Overigens zou deze constructie veel overeenkomsten vertonen met de regulering van abortus (Wöretshofer 1987). Ook de hoogleraar strafrecht Kelk had zo zijn bedenkingen tegen het voorstel van de regering (Kelk 1989). Hoewel de kansen in 1989 groor lijken dat één van beide voorstellen zou worden aangenomen, kwam het echter niet tot een stemming, omdat her kabinet - om andere redenen in mei 1989 ten val werd gebracht.

38 Deze commissie bestond, naast de voorzitter, uit de volgende leden: E. Borst-Eilers, S.A. de Lange, J.J.M. Michels, T.M. Schalken en C.J.M. Schuyt (Remmelink r991: 5).

39 In het kader van de meldingsprocedure was er ook een lijst met aandachtspunten opgesteld, bedoeld om de arts te helpen bij het maken van zijn schriftelijke verslag voor de gemeentelijk lijkschouwer.

40 Het onderzoek maakte duidelijk dat het jaarlijkse aantal euthanasiegevallen zo'n 2300 bedroeg, in plaats van de geschatte 5.000 tot 20.000 (Remmelink 1991: 14).

$4 \mathrm{I}$ Dit conceptvoorstel voor een nieuwe wet wordt op ro april 1992 als wetsvoorstel ingediend. Het wetsvoorstel van december 1987 werd daarmee ingetrokken (Leenen 2000a: 342).

42 Volgens de Wet op de lijkbezorging is voor begraven of crematie een verlof van de ambtenaar van de Burgerlijke Stand nodig. Voordat een dergelijk verlof verleend mag worden, moet er een verklaring van overlijden zijn opgemaakt door de behandelend arts, de gemeentelijk lijkschouwer of moet er een verklaring zijn afgegeven door de Officier van Justitie. Als het om een geval van natuurlijk overlijden gaar, dan kan de arts het zogenoemde 'doodsbriefje A' afgeven. Als het echter om een geval van niet-natuurlijke dood gaat - zoals bij euthanasie, hulp bij zelfdoding en levensbeëindiging zonder verzoek -, moer de gemeentelijk lijkschouwer worden ingeschakeld. Deze brengt dan aan de Officier van Justitie verslag uit over de oorzaak van het overlijden. Zoals uit het onderzoek van de commissie Remmelink was duidelijk geworden vulde meer dan de helf van de artsen die euthanasie had toegepast, toch een verklaring van natuurlijk overlijden in, in plaats van te melden.

43 Bij de KNMG-meldingsprocedure van 1990 was door de geneeskundig hoofdinspecteurs duidelijk gemaakt dat her lijden alleen op 'ernstige somatische ziekten' betrekking had (Spreeuwenberg 1991). 
44 Chabot had een zevental deskundigen geconsulteerd; zij onderschreven zijn beoordeling.

45 Het hof van Leeuwarden had in dit verband het vierde CAL-rapport aangehaald, dit wordt door het arrest van de Hoge Raad bevestigd (Grifftiths 1995). De Hoge Raad concludeerde, afwijkend van de rechrbank en her hof, niet tot ontslag van rechtsvervolging maar tor schuldigverklaring van Chabor, maar zonder oplegging van straf.

Chabot is dus niet strafrechtelijk vervolgd, maar heeft wel in het medisch tucherecht een berisping gekregen in verband mer onzorgvuldig handelen; de consultarie had niet ter plekke plaatsgevonden.

46 Een vergelijkbaar geval vormde de zaak Kadijk, waarbij een huisarts het leven van een drie weken oude baby met zeer ernstig aangeboren afwijkingen had beëindigd. Oók deze casus speelde zich nog af vóór de officiële meldingsprocedure was ingegaan. Ook in dit geval werd het beroep op de noodroestand door de rechtbank geaccepreerd (Redactioneel 1996).

47 In de periode 1990-1994 zijn hierover vier rapporten verschenen. In deze nota's was de afzonderlijke problematiek rond ernstig gehandicapte pasgeborenen, langdurig comateuze pariënten, ernstig demente patiënten en patiënten met een psychiatrische aandoening bespreken. In 1997 is het eindrapport van de KNMG verschenen (KNMG 1997).

48 In een bijdrage aan een bundel over de regulering van morele vraagstukken claimt de rechtssocioloog Griffiths dat de regulering van euthanasie in belangrijke mate her gevolg van zelf-regulering door de medische professie is geweest (Griffiths 2000). Griffiths baseert zijn claim op de rol van de KNMG in het debat over euthanasie. Zo schrijft hij de KNMG een centrale rol toe bij het opstellen van de zorgvuldigheidseisen. Zou zouden de zorgvuldigheidseisen sinds halverwege de jaren tachtig niet wezenlijk meer veranderd zijn, nadat de KNMG deze als zodanig had benoemd in een rapport uit 1984. Dit wekt de indruk dat de KNMG op voorhand een betekenisvolle rol heeft gespeeld, omdat de medische professie een actor is in het debat. Dit hoofdstuk heeft echter inzichtelijk gemaakt dat de zorgvuldigheidseisen het resultaat zijn van een heterogene praktijk. Daarin zijn ondermeer jurisprudentie (zaak Postma en de zaak Wertheim) en rapporten van getuigen-deskundigen van belang zijn geweest. De KNMG bevestigde met haar rapport ideeën die in de euthanasieprakrijk ontwikkeld waren. Zij bezette een dusdanige positie in het netwerk rond euthanasie, dat dit rapport een bezegeling van de vigerende praktijk werd. Hoewel de rol van de medische professie niet zelfstandig onderwerp van studie is geweest, heeft dit onderzoek laten zien dat de rol van de medische professie niet los van andere spelers in het debat kan worden gezien.

49 Het vorige hoofdstuk heeft laten zien dat ethici en juristen zich sterk hebben gemaakt voor een verbetering van de positie van de patiënt door te pleiten voor autonomie en zelfbeschikkingsrecht. Dit komt tot uitdrukking in de eis dat bij gerechtvaardigde levensbeëindiging sprake moet zijn van een uitdrukkelijk verzoek van de patiënt. In de zorgvuldigheidseisen is dit verder aangescherpt tot de eis dat het verzoek om levensbeëindiging vrijwillig en weloverwogen tot stand moet zijn gekomen en duurzaam van aard moet zijn. Pas dan is aan het betreffende zorgvul- 
digheidscriterium voldaan. Toch is het uiteindelijk de arts geworden die her laatste woord heeft. De arts moet het vrijwillige, doordachte en duurzame karakter van het verzoek van de patiënt beoordelen.

so In 1987 stelt de rechtssocioloog Griffiths: '(...) en de mogelijkheid van euthanasie door niet-artsen komt helemaal niet aan de orde' (Griffiths 1987: 690).

SI Aan de eerste eis, het vrijwillige, weloverwogen verzoek kan dan uiteraard niet worden voldaan, maar de andere eisen worden wel toegepast. Overigens zijn de regionale toetsingscommissies op dit moment niet bevoegd om levensbeëindiging zonder verzoek te toetsen.

52 De vijf regionale toetsingscommissies voor euthanasie en hulp bij zelfdoding zijn sinds I november 1998 werkzaam. Deze commissies vallen buiten de onderzoeksperiode. Om te laten zien dat het (materiële) nerwerk rond de zorgvuldigheidseisen zich verder heeft uitgebreid en hoe recht en ethiek hierin een rol spelen worden ze op dit punt alsnog meegenomen.

\section{Noten bij hoofdstuk 6}

I Vanaf de jaren tachtig is er kritiek geweest op de functie van gezondheidsethiek als toegepaste discipline; ze zou meer oplossingsgericht in plaats van filosofisch zijn. Dit verschijnsel is in dit boek aangeduid als proto-juridisering van de ethiek. Zie hoofdstuk één.

2 Gezondheidserhiek en gezondheidsrech zijn mera-disciplines, die zich in verschillende medisch-erhische debatten mengen. Mer 'in actie' wordt hier bedoeld dat het debat over levensbeëindigend handelen als het veld wordt beschouwd, waarin ethiek en recht zich begeven. Zie ook noot drie hoofdstuk één.

3 De drie analyses hebben stuk voor stuk laten zien dat de ontwikkeling van disciplines niet los van de maatschappelijke context en van andere disciplines kan worden gezien. Dit betekent dat de relatie met de medische professie eveneens van belang is. Hoewel dit geen onderwerp van studie was, heeft het empirisch onderzoek laten zien dat ook de driehoeksrelatie tussen recht, ethiek en de medische professie in beweging is. De verschillende coalities met de medische professie zijn eveneens van invloed op de ontwikkeling van zowel recht als ethiek, evenals bijvoorbeeld de maatschappelijke positie van artsen. In dit onderzoek worden veranderingen en implicaties voor de geneeskunde dan ook niet ontkend, maar de aandacht gaat uit naar de manier waarop veranderingen doorwerken in het gezondheidsrecht en de gezondheidsethiek.

4 Het begrip jurisdictie is afkomstig uit de professiesociologie en heeft betrekking op de manier waarop professies zeggenschap opeisen of proberen te behouden over hun activiteiten, zie verder hoofdstuk drie.

5 In het onderhavige onderzoek staat het debat over levensbeëindigend handelen in een medische context als casus centraal. De veronderstelling is dat in andere debatten tegelijkertijd ook strijd is rond zeggenschap, cognitieve ontwikkelingen en het opbouwen van netwerken, alleen zijn de effecten op de ontwikkeling van gezondheidsrecht en gezondheidsethiek daarvan in dit geval niet onderzocht. 
6 Crul haalt hierbij een stelling uit het proefschrift van G. Izaks aan: 'Het heeft geen zin om een onderscheid te maken tussen ziekte en normale veroudering omdat de onderliggende mechanismen vergelijkbaar zijn en beide gepaard gaan mer beperkingen en handicaps' (Izaks 2001). G. Westendorp, hoogleraar geriatrie en begeleider bij het proefschrift van Izaks stelt dat kwalen van ouderdom pas ernstige ziekten worden 'zodra er een medicijn voor is uitgevonden'. Als voorbeeld noemt hij de achteruitgang van het geheugen op hoge leeftijd. 'Dit is thans nog een grijs gebied, maar zodra inzichtelijk is gemaakt wat die vergeetachtigheid drijft, wordt het een ziekte in plaats van iets dat erbij hoort. Als daar een pil voor is, wordt de vraag ernaar vanzelf groter' (de Volkskrant 6 december 200I).

7 Uit de praktijk van de consulenten en voorlichters van de NVVE en De Einder die in Sterfwerk wordt beschreven valt af te leiden dat beide organisaties zeggenschap hebben verworven over hulp bij zelfdoding (Chabot 2001: 68). De organisaties hanteren vaste regels en voorschriften voor de wijze waarop hun consulenten behulpzaam kunnen zijn bij hulp bij zelfdoding. Zo mogen ze bijvoorbeeld niet helpen bij her klaarmaken van de zelfdodingsmedicatie, maar kunnen ze wel een dosis dodelijke middelen regelen via 'Morpheus-koeriers' uit het buitenland. Familie en naasten uit de casus van Sterfwerk spreken vaak hun dankbaarheid uit voor de ondersteuning die de consulenten bij het regisseren van de zelfdoding hebben geboden. In sommige gevallen waren zowel zij als de zelfdoders zeer teleurgesteld in (her uirblijven van) de hulp van hun huisarts in deze emotionele situaties.

8 Dit onderstreept de conclusie van de cultuur-historicus Kennedy dat er meerdere aspecten zitten aan het concept zelfbeschikking. In zijn analyse van het publieke Nederlandse euthanasiedebat stelt Kennedy dat er in het debat altijd twee interpretaties van zelfbeschikking naast elkaar hebben gestaan. Ten eerste verantwoorde of relationele zelfbeschikking, dat wil zeggen waarbij het individu in zijn wens om te sterven ook rekening houdt met anderen of zijn wens in gesprekken met anderen op zijn minst wordt aangescherpt. Ten rweede de meer radicale of absolute vorm van zelfbeschikking, waarbij het individu de stervenswens helemaal zelf bepaalt. Deze laatste vorm van zelfbeschikking is volgens Kennedy sinds eind jaren tachtig steeds meer in berekenis gaan toenemen (Kennedy 2002: 164).

9 Dit betekent dat de conclusie van de eerdergenoemde Kennedy dat er in het Nederlandse eurhanasiebeleid een verschuiving zou zijn van een situatie waarin arts en patiënt naast elkaar staan naar een situatie waarin ze meer tegen over elkaar staan (de pariënt-consument komt bij de arts aankloppen en staat er op dat de arts onmiddellijk gehoor geeft aan zijn stervenswens) wat voorbarig is (Kennedy 2002: 2rI). Het debat ligt wat dat betreft, zoals onderhavige bespreking van de zaak Brongersma laar zien, nog redelijk open.

IO In januari 2002 is het CEG geleidelijk van start gegaan. Het is de bedoeling dat in 2003 het Centrum volledig zal gaan draaien.

II Dit komt primair tot stand via de Gezondheidsraad en de Raad voor de Zorg en dienstverlening. 


\section{LITERATUUR}

Abbott, A.

1991 'The Order of Professionalization. An empirical analysis.' Work and Occupations $18(4): 355-384$.

1988 The System of Professions. An essay on the Division of Expert Labour. Chicago \& London: The University of Chicago Press.

Achterhuis, $\mathrm{H}$.

1993 'Tegen een versmalling van de ethiek', Medisch Contact 48 (25 januari): 789-790.

Achterhuis, H., J. Goud \& F. Koerselman et al.

1995 Als de dood voor het leven. Over professionele hulp bij zelfmoord. Amsterdam: G.A. van Oorschot.

Beaufort, I.D. de \& H.M. Dupuis (eds)

1988 Handboek Gezondheidsethiek. Assen/Maastricht: van Gorcum.

Beemer, T.

1977 'Euthanasie; moraaltheologische overwegingen.' In: P. Muntendam, Euthanasie. Leiden: Stafleu. Pp. 30-47.

1986 'Tegen een gehalveerde ethiek.' In: D. van Tol: Euthanasie wetgeving: andere' wegen. Amsterdam: vu. Pp. 33-47.

Bekker, C. \& W. van der Burg

1994 'Zelfbeschikking: een recht met vele gezichten?' In: W. van der Burg \& P. Ippel: De Siamese Tweeling. Recht en moraal in de biomedische praktijk. Assen: Van Gorcum. Pp. 203-217.

Berg, J.H. van den

1969 Medische macht en medische ethiek. Nijkerk: Callenbach.

Berg, $M$.

1998 'Order (s) and Disorder (s): Of Protocols and Medical Practices.' In: M. Berg \& A. Mol: Differences in Medicine. Unraveling practices, techniques, and bodies.

Durham \& London: Duke University Press. Pp. 226-246.

Bosk, C.L. \& J. Frader

1998 'Institutional Ethics Committees: Sociological Oxymoron, Empirical Black Box.' In: R. de Vries \& J. Subedi, Bioethics and Society. Constructing the Ethical' Enterprise. Upper Saddle River (NJ): Prentice Hall. Pp. 94-ri6.

Brenninkmeijer, A.J.

1957 'Houding van de arts ten opzichte van de ongeneeslijk zieke.' Rooms-katholiek Artsenblad 36 (april): II3-II8. 
Burg, W. van der

$200 \mathrm{I}$ Dynamisch recht. De interactie tussen recht, ethiek en samenleving. Den Haag: Boom Juridische Uitgevers.

Burg, W. van der \& $\mathrm{P}$. Ippel, (eds)

1994 De Siamese tweeling. Recht en moraal in de biomedische praktijk. Assen: van Gorcum.

Buijs, $\mathrm{H}$.

1979 'Euthanasie of levensbekorting. De plaats van de arts.' Medisch Contact34 (12): 371-374.

Catz, W.E.

1960 'Reanimatie-plicht.' Medisch Contact. 323-324.

CBG

1988 'Verslag van werkzaamheden.' Utrecht: Universitair Centrum voor Bio-ethiek en Gezondheidsrecht.

CEKUN

1999 'CEKUN jaarverslag 1999.' Nijmegen: CEKUN.

Chabot, B.E.

$200 \mathrm{I}$ Sterfwerk. De dramaturgie van zelfdoding in eigen kring. Nijmegen: sun.

Commentaar

1975 'Euthanasie.' Medisch Contact 30 (1): 3.

Crigger, $\mathrm{B}$.

1998 'As Time Goes By: An Intellectual Ennography of Bioethics.' In: R. de Vries \& J. Subedi, Bioethics and Society. Constructing the Ethical Enterprise. Upper Saddle River: Prentice Hall. Pp. 193-215.

Crul, B.V.M.

2001 'Legitimatie van euthanasie.' Medisch Contact 45 (56): 1639.

Delden, J.J.M.

199I Het nalaten van medische behandelingen bij meerderjarige wilsonbekwame

Dijk, D. van mensen. Den Haag: Gezondheidsraad. Pp. I03.

1994 'De wijziging van de Wet op de Lijkbezorging.' Tijdschrift voor Geneeskunde en Ethiek 4 (4): 94-97.

Dillmann, R.J.M.

1994 'Ethiek in de medische praktijk. Adviezen KNMG-secretariaat inzake medische beslissingen rond het levenseinde.' Medisch Contact 49 (17): 58I-583.

Dillmann, R.J.M., J. Legemaate \& E.C. de Jong

1997 Medisch handelen rond het levenseinde bij wilsonbekwame patiënten. Commissie Aanvaardbaarheid Levensbeëindigend handelen Koninklijke Nederlandsche Maatschappij tot bevordering der Geneeskunst. Houten: Bohn, Stafleu \& van Loghem.

Drift, L. van der

I970 'Medische ethiek anno 1970.' Medisch Contact 25: 413-417.

Drion, $\mathrm{H}$.

1992 Het zelfgewilde einde van oude mensen. Amsterdam: Balans. 
Dupuis, H.M.

1976 Medische ethiek in perspectief. Een onderzoek naar normen en argumeniaties in de (meáische) ethiek. Leiden: Stafleu.

I988 'Dilemma's voor de arts ... en hoe ermee om te gaan. Een commentaar vanuit ethisch perspectief.' In: I.D. de Beaufort \& H.M. Dupuis, Handboek Gezondheidsethiek. Assen/Maastricht: van Gorcum.

1988a 'Ontwikkelingen in de medische ethiek. Van artsencode naar ethiek van de gezondheidszorg.' In: I.D. de Beaufort \& H.M. Dupuis, Handboek Gezondheidsethiek. Assen/Maastricht: van Gorcum. Pp. 2I-26.

1988c 'Pariënten in coma, een oplosbaar probleem.' Nederlands Tijdschrift voor Geneeskunde 42 (132): 1926-1928.

1996 'Oefenen in berusting of in redelijkheid?' In: F. Geraredts \& L. de Jong, Ergo Cogito. Groningen: Historische Uitgeverij. Pp. 55-72.

Dupuis, H.M., I. de Beaufort \& E. van der Does et al.

1994 Wat zou u doen? Medisch-ethische casuistiek met commentaren. Houten/Zaventem: Bohn, Stafleu \& Van Loghum.

Dupuis, H.M. \& P.J. Thung

1983 Voordelen van de twijfel. Een inleiding tot de gezondheidsethiek. Alphen aan de Rijn/Brussel: Samson Stafleu.

Dute, J.C.J. \& H.E.G.M. Hermans

2000 Regulering van gezondheidszorg. Leerboek voor universitair en hoger onderwijs en managementopleidingen. Maarssen: Elsevier.

Ekelmans, J.

1971 'De mondige sterveling.' Medisch Contact 26: 791-795.

1972 'Juridische aspecten van euthanasie.' Nederlands Tijdschrift voor Geneeskunde II6: 1096-Iro2.

1973 'Het euthanasievraagstuk' Medisch Contact (28): 866.

Enschedé, C.J.

1985 De Arts en de Dood. Deventer: Kluwer.

1986 'Ingezonden. Over Euthanasie en Strafrecht.' Tijdschrift voor Gezondheidsrecht (mei/juni). 189-190.

Es, J.C. van

1977 'Huisarts en de preventie van euchanasie.' In: Euthanasie. Leiden: Stafleu. Pp. 147-267.

1978 'Paradigma's van de huisartsgeneeskunde.' Huisarts en wetenschap 21: 45I-458.

Es, J.C. van \& W.R. Vroom-Kastelein

1986 'Arts en Rechr. Meer aandacht voor rechtspraak in Medisch Contact.' Medisch Contact 26 (4I): 822 .

Euthanasie, C.O.M.P.

1991 'Medische beslissingen rond het levenseinde.' 's-Gravenhage: Ministerie van Justitie, Ministerie van Welzijn, Volksgezondheid en Cultuur. 70.

Fleck, L.

1935 'Scientific observation and perception in general.' Prezeglad Filozoficzny 38. 
1980 Entstehung und Entwicklung einer wissenschaftlichen Tatsache. Einführung in die Lehre vom Denkstil und Denkkollectiv. Frankfurt a.M.: Suhrkamp.

Fox, R.C. \& J.P. Swazey

1984 'Medical Morality is not Bioethics - Medical Ethics in China and the United States.' Perspectives in Biology and Medicine 27: 337-360.

Gevers, J.K.M.

1993 'Medische beslissingen rond her levenseinde van wilsonbekwame pariënten: de discussienota's van de KNMG-commissie.' Tijdschrift voor Gezondheidsrecht 8 (december): 464-474.

1996 'Gezondheidsrecht als discipline.' In: KNAw, Gezondheidsrecht en gezondbeidsethiek. Positie en taken ten opzichte van de geneeskunde. Amsterdam: KNAW. $3 \mathrm{I}-36$.

Gezondheidsraad

1973 'Advies inzake euthanasie.' 's-Gravenhage, Ministerie van Volksgezondheid en Milieuhygiëne.

1982 'Advies inzake euthanasie III.' 's-Gravenhage: Gezondheidsraad.

1987 'Advies Zorgvuldigheidseisen euthanasie 36.' 's-Gravenhage: Gezondheidsraad.

Gezondheidsraad, B.G.e.G

1992 'Medische beslissingen rond het levenseinde.' Den Haag: Gezondheidsraad. Gezondheidsraad, C.M.E.

1972 'Interim-advies inzake euthanasie.' 's-Gravenhage: Gezondheidsraad.

I975 'Euthanasie bij pasgeborenen.' Rijswijk, Gezondheidsraad.

Gieryn, T.F.

1983 'Boundary-Work and the Demarcation of Science from Non-Science.' American Sociological Review 48 (december): 781-795.

1999 Cultural Boundaries of Science. Credibility on the line. Chicago \& London: University of Chicago Press.

Goudsmit, C.J.

1969 'Discussie over: De medische ethiek met betrekking tot de nieuwste ontwikkelingen in de geneeskunde.' Medisch Contact 24 (14): 386.

Graaf, J. de

1985 'Een goede dood op verzoek.' In: J. de Graaf, W.C.M. Klijn \& C. van der Meer et al., Euthanasie. Recht, ethiek en medische praktijk. Deventer: Kluwer. Pp. I-I6.

1990 'Ethische aspecten van stervensbegeleiding en euthanasie.' In: H.A.M.J. ten Have \& D.P. Engberts et al., Ethiek en recht in de gezondheidszorg. Deventer: Kluwer. Pp. IoI-II6.

Graaf, J. de, W.C.M. Klijn \& C. van der Meer et al.

I985 Euthanasie. Recht, ethiek en medische praktijk.Deventer: Kluwer. Griffiths, J.

1987 'Een toeschouwersperspectief op de euthanasiediscussie.' Nederlands Juristenblad 22 (mei): 68I-692. 
1995 'Balans van de recente rechrsontwikkeling rondom euthanasie en andere levensbekortende handelingen.' Themis 3: 87-107.

2000 'Self-regulation by the Dutch Medical profession of Medical Behavior that potentially shortens life.' In: H. Krabbendam \& H.M. Ten Napel, Regulating Morality. A Comparison of the Role of the State in Mastering the Mores in the Netherlands and the United States. Antwerpen-Apeldoorn, E.M. Meijers Institute \& Maklu. Pp. 173-190.

Gusfield, J.R.

1981 The Culture Of Public Problems: Drinking-Driving and the symbolic order. Chicago/London: University of Chicago Press.

Hagendijk, R.

1996 Wetenschap, Constructivisme en Cultuur. Amsterdam: Luna Negra.

Hajer, M.A.

1995 The Politics of Environmental Discourse. Ecological Modernization and the Policy Process. Oxford: Clarendon Press.

Harrison, $\mathrm{E}$.

1987 'Whigs, prigs and historians of science.' Nature 329 (17 september): 213-214. Hartogh, G. den

I995 'Patiënten in een vegetatieve toestand.' Medisch Contact 50 (39): 1225-1228.

Have, H. ten \& $\mathrm{G}$. Kimsma

1987 Geneeskunde tussen droom en drama. Voortplanting, ethiek en vooruitgang. Kampen: Kok/Agora.

Have, H.A.M.J. ten, R.H.J. ter Meulen et al.

1998 Medische ethiek. Houten/Diegem: Bohn Stafleu Van Loghem.

Have, H. ten \& W.R. Vroom-Kastelein

1987 'Erhiek en recht in de gezondheidszorg.' Metamedica (66): 356-361.

Have, H.A.M.J. ten \& F.C.B. van Wijmen et al.

1994 'Medische ethiek en gezondheidsrecht in het Nederlands medisch onderwijs. I. Medische ethiek.' Nederlands Tijdschrift voor Geneeskunde I38 (8): 414-418.

Heering, H.J.

1971 'De grenzen van het menselijk bestaan; medisch-ethische overwegingen.' Medisch Contact 26 (33): 854-86I.

1977 'Euthanasie; echische overwegingen.' In: P. Muntendam: Euthanasie. Leiden: Stafleu. Pp. III: 269.

Hendriks, R.P.J.

1992 De Baby Ross Case. Maastricht: Rijksuniversiteit Limburg. Hermans, E.H. (ed.)

1970 Recent Medisch Ethisch Denken II. Leiden: Stafleu.

Hoofdakker, R.H. van den

1970 Het bolwerk der beterweters-Over medische ethiek en de status quo. Amsterdam: Kritiese Bibliotheek Van Gennep. 


\section{Hoofdbestuur}

1970 'Kort verslag 155ste Algemene Vergadering.' Medisch Contact 25: 937-94I, 96I964.

Hoornbeeck, J.

I65I Euthanasia, ofte Wel-Sterven. Utrecht: Jan van Waesberge.

Houtepen, R.

1998 'The Social Construction of Euthanasia and Medical Ethics in the Netherlands.' In: R. de Vries \& J. Subedi, Bioethics and Society. Upper Saddle River: Prentice Hall. Pp. II7-I44.

Houtepen, R. \& L. Kater

2001 'De wieg van de huidige medische ethiek. Artsen, juristen, ethici en euthanasie in de vroege jaren zeventig.' Tijdschrift voor Geneeskunde en Ethiek II (I): 9-I4.

Houtepen, R. \& G. Widdershoven

1994 'Proceduralisme in de gezondheidsethiek.' Gezondheid - Theorie en praktijk 2 $(\mathrm{I}): 2-4$.

Hubben, J.H.

1993 'Levensbeëindiging van ernstig gehandicapte pasgeborenen en ernstig demente bejaarden: waar ligt de grens?' Tijdschrift voor Gezondheidsrecht (juni): 207213.

IGE

1986 Het Instituut voor Gezondheidsetbiek. Maastricht: Ploegsma.

Indewey Gerlings-Huurman, T.

1977 Het Leeuwarder Euthanasieproces. Feiten en commentaren. Nijkerk: Callenbach.

Izaks, G.J.

2001 Determinants of mortality in old age. Leiden, Proefschrift Universiteit Leiden. Jaarverslag

2001 'Jaarverslag 2000.' Regionale toetsingscommissies. Arnhem: sı. Jacobs, F.C.L.M.

1987 'De figuur van de veronderstelde wil.' In: G.A. van der Wal, Eurhanasie, knelpunten in een discussie. Baarn: Ambo. Pp. 83-ro9.

Kalkman-Bogerd, L.E.

1990 'Juridische aspecten van stervensbegeleiding.' In: H.A. ten Have \& D.P. Engberts et al., Ethiek en recht in de gezondheidszorg. Deventer: Kluwer. Pp. 20I-233.

Kater, L.

2002 'Enkele pioniers van het euthanasiedebat.' Tijdschrift voor Geneeskunde en Ethiek 12 (2): 43-48.

Keasberry, $\mathrm{H}$.

1985 'Enkele rechtsfilosofische aspecten van euthanasie.' In: J.L.M. Elders, Euthanasie. Recht en ethiek. Assen/Maastricht: Van Gorcum. Pp. 57-84.

Kelk, C.

1989 'Euthanasie-wetgeving: nu of nooit?' Nederlands Juristen Blad (14): 448-450. 
Kennedy, J.

2002 Een weloverwogen dood. Euthanasie in Nederland. Amsterdam: Bert Bakker. Klever, W.N.A.

1970 'Algemene beschouwingen over de beginselen van de medische ethiek.' Reken$\operatorname{schap}(\mathrm{I} 7)$ : I-II.

1972 'Euthanasie. Ethische beschouwingen over het menselijk sterven.' Algemeen Nederlands Tijdschrift voor Wijsbegeerte 64: 297-304.

Klijn, W.C.M.

1985 a 'Euchanasie. Ethische analyse en waardering.' In: F.J.M. Feldbrugge, Euthanasie. Recht, ethiek en medische praktijk.. Amsterdam: Rechstkundige Afdeling Thijmgenootschap en de Calvinistische Juristen Vereniging. Pp. 17-68.

1985b 'Eurhanasie en de Hoge Raad.' Nederlands Juristen Blad 8: 245-254. KNMG

1959 Medische ethiek en Gedragsleer. Utrecht.

1975 'Discussienota van de Werkgroep Euthanasie.'

1984 'KNмG Standpunt inzake euthanasie.' Medisch Contact 31: 990-996.

I990 'Richclijnen meldingsprocedure eurhanasie en hulp bij zelfdoding.' Medisch Contact 45 (44): 1303-1304.

1991 'Meldingsprocedure euthanasie.' Medisch Contact 46 (2): 62.

1993 'Discussienota levensbeeïndigend handelen bij wilsonbekwame patiënten. Deel i Zwaar defecte pasgeborenen.' Utrecht: KNMG.

1993 'Discussienota levensbeëindigend handelen bij wilsonbekwame patiënten. Deel III: ernstig demente patiënten.' Utrecht: KNMG. Pp. 74.

1997 Medisch handelen rond het levenseinde bij wilsonbekwame patiënten. Houten/ Diegem: Bohn Stafleu Van Loghem.

Komrer, A.

1983 'De onmacht van het getal.' Kennis en Methode 3: 202-226. Kooyman, F.C.

1959 “'Reanimatie”, aanwinst, probleem en opgave.' Medisch Contact I4 (29): 44I-444. 1960 'Reanimatie.' Medisch Contact Is (14): 186-187.

Kortbeek, L.H. (ed.)

1968 Recent Medisch Ethisch Denken 1. De Nederlandse Bibliotheek der Geneeskunde. Leiden: Stafleu.

Kuhn, T.S.

1962 The Structure of Scientific Revolutions. Chicago: University of Chicago Press. Kuitert, H.M.

1981 Een gewenste dood. Euthanasie en zelfbeschikking als moreel en godsdienstig probleem. Baarn: Ten Have.

1989 Mag alles wat kan? Ethiek en Medisch handelen. Baarn: Ten Have.

1993 Mag er een einde komen aan het bittere einde? Levensbeëindiging in de context van stervensbegeleiding. Baarn: Ten Have.

Lange, S.A. de

1964 'Medische en ethische problemen rondom reanimatie.' Medisch Contact 19 (8): II 
Langemeijer, G.E.

1960 'Reanimatie.' Medisch Contact is (14): 188-191.

Langemeijer, G.E., C.J. Enschedé \& T.W.v. Veen

1986 'Arts en samenleving. Euthanasie heeft geen wetgeving nodig.' Nederlands Tijdschrift voor Geneeskunde I30 (5): 223-225,

Latour, B.

1988 Wetenschap in actie. Amsterdam: Bert Bakker.

Leenen, H.J.J.

1968 'Gezondheidsrecht. Een poging tot plaatsbepaling.' Tijdschrift voor Sociale Geneeskunde 22: 778-785.

1977 'Euthanasie in het gezondheidsrecht.' In: P. Muntendam, Euthanasie. Leiden: Stafleu.

1978 'De geschiedenis van de Vereniging voor Gezondheidsrecht.' Tijdschrift voor Gezondheidsrecht: 184-189.

1978 Rechten van mensen in de gezondheidszorg. Een gezondheidsrechtelijke studie. Alphen ad Rijn/Brussel: Samsom.

1979 'Jaarvergadering Vereniging voor Gezondheidsrecht. De behoefte aan universitaire voorzieningen voor gezondheidsrecht.' Tijdschrift voor Gezondheidsrecht: I14-116.

1981 Gezondheidszorg en recht. Een gezondheidsrechtelijke studie. Alphen a/d Rijn/ Brussel: Samsom.

I982 'Euthanasie en hulp bij zelfdoding. Van Leeuwarden naar Rotterdam.' Nederlands Juristen Blad 4: 103-106.

1983 'Jurisprudentie. Nr. I983/29 Euthanasie bewezen maar niet strafbaar verklaard (ontslag van rechtsvervolging).' Tijdschrift voor Gezondheidsrecht, juli/augustus 1983: 205-208.

1985 'Geneeskunden en Rechr. Euthanasie voor de Hoge Raad.' Nederlands Tijdschrift voor Geneeskunde I29 (9): 4I4-4I7.

1985 'Kwaliteit van leven, een bruikbaar begrip?' Tijdschrift voor Gezondheidsrecht (mei/juni): 152-156.

1986 'Boekrecensies. Ch. Enschedé, De arts en de dood.' Tijdschrift voor Gezondheidsrecht (januari/februari): 73-74.

1988a 'Geneeskunde en recht. Eurhanasie en wetgeving.' Nederlands Tijdschrift voor Geneeskunde 132 (37): 1702-1705.

1988b Handboek Gezondheidsrecht. Rechten van mensen in de gezondheidszorg. Amsterdam: Samson.

1989a 'Grondrechten van mensen in de gezondheidszorg: beginselen of belangenafweging?' Tijdschrift voor Gezondheidsrecht (juni): 227-233.

1989b 'Meer verband.' Tijdschrift voor Gezondheidsrecht (juni): 234-235.

1992a 'Het standpunt van het kabinet inzake regeling van euthanasie.' Tijdschrift voor Gezondheidsrecht (januari): 2-8.

1992b 'Mag een zorgvuldig handelend arts her leven beëindigen zonder verzoek?' Tijdschrift voor Geneeskunde en Ethiek 2 (2): 47-48. 


1992C 'Vereniging voor Gezondheidsrecht 25 jaar: geschiedenis van de start.' Tijdschrift voor Gezondheidsrecht (april): 128-134.

1993 'Vijfentwintig jaar gezondheidsrecht.' In: J.H. Hubben \& H.D.C. Roscam Abbing, Gezondheidsrecht in perspectief. Utrecht: De Tijdstroom. Pp. 16-27.

1994a 'Boekrecensie. H. Kuitert, Mag er een einde komen aan het bittere einde?' Tijdschrift voor Gezondheidsrecht $\mathrm{x}: 48$.

$1994 \mathrm{~b}$ 'Gezondheidsethiek en gezondheidsrecht, over de ontmoeting tussen ethici en juristen. In: J.S. Reinders \& W.J. Dondorp, Een mens moet van ophouden weten - in gesprek met Harry Kuitert. Opstellen over medische ethiek en gezondheidszorg. Baarn: Ten Have.

I995 'Actieve levensbeëindiging bij een ernstig gehandicapre baby.' Nederlands Juristen Blad (23): $851-852$.

2000 Handboek gezondheidsrecht. Deel I. Rechten van mensen in de gezondheidszorg. Houten/Diegem: Bohn Stafleu Van Loghum.

$2000 \mathrm{~b}$ Met het oog op gezondheid en recht. Een terugblik door prof. dr. H.J.J. Leenen. Houten/Diegem:Bohn Stafleu Van Loghum.

Legemaate, J.

1998a 'De juridische context van euthanasie en de inhoud van de zorgvuldigheidseisen.' In: J. Legemaate \& R.J.M. Dillmann, Beëindigend handelen door een arts: tussen norm en praktijk. Houten/Diegem: Bohn Stafleu van Loghum. Pp. 26-44.

1998b 'Twenty-five Years of Dutch Experience and Policy on Euchanasia and Assisted Suicide: An Overview.' In: D.C. Thomasma en T. Kimbrough-Kushner et al., Asking to die: inside the dutch debate about euthanasia. Dordrecht/ Boston/London: Kluwer Academic Publishers: 19-34.

Legemaate, J. \& R.J.M. Dillmann, Eds.

1998 Levensbeeindigend handelen door een arts: tussen norm en praktijk. Houtem/ Diegem, Bohn Stafleu Van Loghum.

Leuftink, A.E. \& J. Diepersloor

1973 'Het Euthanasie-vraagstuk.' Medisch Contact 28 (19): 587-588.

Lindeboom, G.A.

1970 'Medisch-ethische bezinning in Protestantse kring.' Metamedica 49 (ro): 4II-4I 6 .

Maneschijn, G.

1993 'Verhouding ethiek en recht.' In: H.A.M.J. ten Have \& D.P. Engberts et al., Ethiek en recht in de gezondheidszorg. Deventer: Kluwer. Pp. V I-99.

Manschor, H. \& M. Verkerk, (eds)

1994 Ethiek van de zorg. Een discussie. Amsterdam/Meppel: Boom.

Marlet, J.J.C.

1969 'Euthanasie.' In: D.N.B.d. Geneeskunde, Recent Medisch Ethisch Denken I. Leiden: Stafleu. Pp. 40: 296.

Mechelen, J.J. van

1969 'Redactioneel - Ethiek in veranderend tijdsbeeld.' Medisch Contact 24 (31): 853-854. 
1970 'Dekomende Algemene Vergadering - vraagstuk van de ethiek.' Medisch Contact $25(\mathrm{x} 2): 273-274$.

Meer, C. van der

1971 Een geneeskundige confrontatie met de dood. Leiden: Stafleu.

Meerman, D.

1991 Goed doen door dood te maken. Een analyse van van de morele argumentatie in viff maatse happelijke debatten voer euthanasie tussen 1870 en 1940 in Engeland en Duistand. Kampen: J.H. Kok.

Mertens, A.T.L.M.

${ }_{1965}$ 'Gezondheidsrechr.' Tijdschrift voor Sociale Geneeskunde 43 (9): 309.

Mertens, A.T.L.M. \& L.A.M. Stolte

1958 'Arts en Reche.' Universiteit en hogeschool 4 (14): 214-224.

Mesman, J.

2002 Ervaren pioniers. Omgaan met twijfel in de intensive care voor pasgeborenen. Amsterdam: Aksant.

Mol, A. \& P. van Lieshour

1989 Ziek is het woord niet. Medicalisering, normalisering en de veranderde taal van de huisarisgeneeskunde en de gezondheidszorg, 1945-1985. Nijmegen: SUN.

Möller, M. \& R. Huxrable

2001 'Euthanasia in the Necherlands: the case of 'life fatigue.' New Law Journal I5I (november 2): 1600-160r.

Muntendam, P., (ed.)

1977 Euthanasie. De Nederlandse Bibliorheek der Geneeskunde. Leiden: Stafleu. Musschenga, A.W.

1987 'Kwaliteit van leven: grond voor levensbeëindiging?' In: G.A. Van der Wal, Euthanasie knelpunten in een discussie.. Baarn: Ambo. Pp. rro-Iqr.

Nederlands Gesprek Centrum

1975 Euthanasie. Baarn: Bosch \& Keuning.

Nieuwenkamp, J.H.W.K.

1993 'Wat kan de ethiek voor her beleid betekenen? De rol van de ethiek en van ethici bij het beleid.' In: F.W.A. Brom \& B.J. van den Bergh er al., Beleid en ethiek. Assen: van Gorcum. Pp. 34-42.

NVBE

2000 'Nederlandse Vereniging voor Bio-erhiek - Informatiefolder.'

NVVK

1992 'Doen of laten? Grenzen van het medisch handelen in de neonatologie.' Utrecht.

Oostveen, M.

$200 \mathrm{I}$ 'Huisarts Sutorius voelt zich onbegrepen.' NRC Handelsblad (9 november 200I): 2.

Otter, G. den

I963 'Reanimatie.' Soteria: orgaan van de Protestants-Christelijke Artsenorganisatie in Nederland: I82-186. 
Paus Pius XII

1957 'Rede tot anaesthesisten.' Katholiek Archief 13 (I): I-5.

Prick, J.J.

1969a 'Collega Prick antwoordr Mr. Goudsmit.' Medisch Contact 24 (18): 504-505.

$1969 \mathrm{~b}$ 'De medische ethiek met betrekking tot de nieuwste ontwikkelingen in de geneeskunde.' Medisch Contact 24 (4): 83-85.

Putte, L.B.A. (ed.)

1997 Gezondheidsrecht en Gezondheidsethiek. Positie en taken ten opzichte van de geneeskunde. Amsterdam: KNAw.

Rang, J.F.

1972a 'Juridische vragen rondom de euthanasie.' In: J.T.R. Schreuder \& J.F. Rang et al., Leven tot (w)elke prijs? Lochem: De Tijdstroom. Pp. 18-25.

$1972 \mathrm{~b}$ 'Juridische vragen rondom de euthanasie.' Het Ziekenhuis 2 (5): 269-272.

1973 Patiëntenrecht. Leiden: Stafleu.

1974 'Gezondheidsrecht in ontwikkeling.' Utrecht: Calvinistische juristen-vereni-

Rasker, J.J. ging.

1974 'Het Leeuwarder euchanasieproces.' Nederlands Juristen Blad (II): 345-352.

Rasker, J.J. \&' G. van Hellemondt

1984 'Euthanasie, een stap terug? Visie van medici op recente rechterlijke uitspraken.' Nederlands Juristen Blat 27: 823-8:7.

Redactioneel

1973 'De rechter en euthanasie. Vonnis Leeuwarden conform inzichten getuigedeskundige.' Medisch Contact 28: 373.

1992 'Het politieke euthanasiedebat: een zachte dood gestorven.' Tijdschrift voor Geneeskunde en Ethiek 2 (2): 33.

1996 'Arts en Rechr. Uitspraak van de arrondisementsrechtbank te Groningen d.d. 13 november 1995.' Medisch Contact 5I (6): 199-202.

Ree, F. van

2001 'Genoeg van het leven. Levensmoeheid als grond voor hulp bij zelfdoding.' Medisch Contact 45 (II): 426-428.

Reinders, $\mathrm{H}$.

1994 'De grenzen van het rechtendiscours.' In: H. Manschot \& M. Verkerk, Ethiek van de zorg. Een discussie. Amsterdam/Meppel: Boom. Pp. 74-96.

Reinders, J.S.

1997 'Weg uit de ivoren toren? Kanttekeningen bij de tussentijdse evaluatie van het Centrum voor Ethiek Kun.' Tijdschrift voor Geneeskunde en Ethiek 7 (3): 90-92.

2000 Ethiek in de zorg voor mensen met een verstandelijke handicap. Amsterdam: Boom.

Remmelink, C.

1991 'Medische beslissingen rond het levenseinde. Rapport van de Commissie onderzoek medische praktijk inzake euchanasie.' 's-Gravenhage: 70. 
Roelink, $\mathrm{H}$.

I970 'De Koninklijke Nederlandsche Maatschappij tot Bevordering der Geneeskunst en de Medische Ethiek.' Metamedica 49 (10): 385-395.

1971 'Medische ethiek en Gezondheidszorg.' Medisch Contact 26: 1123-1124. Rood, M.G.

1973 'Euthanasie-een discussie. Normen en Euthanasie.' Rekenschap 3 (20): II8-I26. Root Wolpe, P.

1998 'TheTriumph of Autonomy in American Bioethics: A Sociological View.' In: R. de Vries \& J. Subedi, Bioethics and Society. Constructing the Ethical Enterprise. Upper Saddle River: Prentice Hall. Pp. 38-59.

Roscam Abbing, H.D.C.

1983 In de beperking toont zich de meester. Gezondheidsrecht tussen geneeskunde en recht. Rede uitgesproken bij de aanvaarding van het ambt van buitengewoon hoogleraar in het gezondheidsrecht aan de Rijksuniversiteit Limburg op vrijdag 7 oktober 1983. Alphen ad Rijn: Samson.

1985 a 'Euthanasie en hulp bij zelfdoding; een juridische beschouwing over het rapport van de Staatscommissie.' Nederlands Tijdschrift voor Geneeskunde 48 (129): 2294-2296.

1985b 'Eurhanasie en mensenrechten.' In: J. Elders e.a., Euthanasie, recht en ethiek. Assen/Maastricht: Van Gorcum. Pp. 48-56.

Roscam Abbing, H.D.C. \& R.J.M. Dillmann

1997 'Gezondheidsrecht en gezondheidsethiek. Een dialoog (r).' Medisch Contact $52(7)$ : 220-224.

1997 'Gezondheidsrecht en gezondheidsethiek. Een dialoog (2).' Medisch Contact $52(9): 287-289$.

Rothman, D.J.

1991 Strangers at the bedside: a history of how law and bioethics transformed medical Rümke, H.C. decision making. New York: Basis Books.

1959 'De dokter en het probleem van de dood.' Nederlands Tijdschrift voor Geneeskunde 42: 2097-2102.

RVZ

1999 'Erhiek met beleid.' Zoetermeer: Raad voor de Volksgezondheid en Zorg. Salters, L.A.G.

1988 'Pasgeborenen in doodsnood: de wettelijke plicht tot immoreel gedrag.' In: I.D. de Beaufort \& H.M. Dupuis, Handboek Gezondheidsethiek. Assen/ Maastricht: Van Gorcum.

Sanders, K.

1973 'Het euthanasievraagstuk. Brieven aan de redactie.' Medisch Contact 28: 714-715. Schalken, $\mathrm{T}$.

1995 'Waar het recht capituleerde. De Hoge Raad en de ontmaatschappelijking van het euthanasiedebat.' In: H. Achterhuis \& J. Goud et al., Als de dood voor het leven. Over professionele hulp bij zelfmoord. Amsterdam: Van Oorschot. Pp. $70-82$. 
Schalken, T.M.

1984 'Euthanasie en de rechtspolitieke betekenis van het gewetensconflict.' Nederlands Juristen Blad 2: 39-50.

1985 'Euchanasie en handhaving van recht. Normatieve, procedurele en strafrechtspolitieke aspecten van het vervolgingsbeleid.' In: Euthanasie. Recht, ethiek en medische praktijk. Deventer: Kluwer. Pp. 107-173.

Schillebeeckx, E.C.F.A.

1968 'Wijsgerig-antropologische beschouwingen over de manipuleerbaarheid van het sterven.' Katholiek Artsenblad 47 (12): 361369.

Scholten, E.G.

1983 'Euthanasie ex lege artis? Aantekeningen naar aanleiding van de terechtzitcing van het gerechtshof te Amsterdam d.d. 3 november 1983.' Medisch Contact 46: I 447 -I 448 .

Schuurmans Stekhoven, W.

1969a 'Arts en Wet. Professor van den Bergs pleidooi voor actieve euthanasie.' Nederlands Tijdschrift voor Geneeskunde 31 (113): 1358-1360.

1969b 'Tussen leven en dood. Medisch-juridische beschouwing over het recht om te sterven.' Intermediair (31-10-1969): 17, 19, 27.

Schuyt, C.J.M.

1993 'Tussen witte jassen en zwarte toga's - de plaats van het gezondheidsrecht in de moderne samenleving.' In: J.H. Hubben \& H.D.C. Roscam Abbing, Gezondheidsrecht in perspectief. 25 jaar Vereniging voor Gezondheidsrecht. Utrecht, De Tijdstroom. Pp. 156-168.

1995 Tegendraadse werkingen. Sociologische opstellen over de onvoorziene gevolgen van verzorging en verzekering. Amsterdam: Amsterdam University Press.

1997 'Het scherp slijpende mes van recht en ethiek.' In: I.D. de Beaufort \& J.K.M. Gevers et al., Gezondheidsrecht en Gezondheidsethiek. Positie en taken ten opzichte van de geneeskunde. Amsterdam: KNAw.

Sevenhuijsen, $\mathrm{S}$.

1996 Oordelen met zorg. Feministische beschouwingen over recht, moraal en politiek. Amsterdam/Meppel: Boom.

Sluyters, B.

1985 Geknipt verband. Deventer: Kluwer.

1989 'Ingezonden. Verknipt Verband.' Tijdschrift voor Gezondheidsrecht (juni): 233-234.

Sporken, C.P.

1965a 'Medische ethiek en levensverlenging.' R.K. artsenblad: orgaan van de R.K. Artsenvereniging 44 (II): 375-398.

1965b 'Sterven als levensopgave.' Rooms-Katholiek Artsenblad: 277-283.

1968 'Vragen naar het irreversibel moment van de dood krijgt opnieuw dringend karakter.' Medisch Contact: 445-446.

1969a 'Medische ethiek als Cultuurkritiek. Naar aanleiding van revalidarie, levens-' verlenging en euthanasie.' Medisch Contact 24 (51/52): 1431-1434.

I969b Voorlopige diagnose. Inleiding tot een medische ethiek. Bilthoven: Ambo. 
I970a 'Stervensbegeleiding: medisch-ethische plicht?' Theologie en Pastoraat I (66): I6I-170.

1970b 'Vijftig jaar medische ethiek in het Katholieke Artsenblad.' Metamedica: 395-4II.

1971 'Medische ethiek andermaal in discussie.' Metamedica: 232-236.

1972a 'Levenshulp, stervenshulp en euthanasie.' In: D.T.R. Schreuder \& J. F. Rang et al., Leven tot (w)elke prijs? Lochem: De Tijdstroom. Pp. 25-35.

1972b 'Medische ethiek in discussie III: Individu en maatschappij.' Metamedica: 30-33.

1972 'Stervenshulp en euthanasie.' In: C.P. Sporken \& J. Michels et al., De laatste levensfase. Bilthoven: Ambo.

Sporken, P.

1973 'Stervenshulp en euthanasie.' Medisch Contact 28 (2): 54-57.

1977 Ethiek en gezondheidszorg. Baarn: Ambo.

Spreeuwenberg, C.

1988 'Levensbeëindiging buiten aanwezigheid van een uirdrukkelijk verzoek van de betrokkene.' In: H.M. Dupuis \& I.D. de Beaufort, Handboek Gezondheidsethiek. Assen/Maastricht: van Gorcum. Pp. 48r-498.

1991 'Geen euthanasie bij psychiatrie?' Medisch Contact 46 (25): 771.

1997 'Een discussie over gezondheidsrecht en gezondheidsethiek.' Medisch Contact 52 (7): 213 .

Staatscommissie

1985 'Euthanasie.' 's-Gravenhage: Staatsuitgeverij.

Stolte, J.B.

1960 'Reanimatie en de grenzen van kunstmacige levensverlenging.' $R . K$. Artsenblad 39 (april): 84-88.

1968 'Kunstmatige verlenging van het leven.' In: L.H. Kortbeek, Recent Medisch Ethisch Denken I. Leiden: Stafleu. Pp. 40: 139-145.

Stuyt, L.B.J. \& J.C. van Es

1984 'Herbezinning op ethiek.' Medisch Contact 39: 1231-1232.

Tellegen, F.P.A.

1970 'Ethiek in de cultuuromslag: ter inleiding.' Metamedica 382-385.

Terborgh-Dupuis, $\mathrm{H}$.

1976 Medische ethiek in perspectief. Leiden: Stafleu.

1985 'Het rapport van de Staatscommisie Euthanasie; een commentaar vanuit de ethiek.' Nederlands Tijdschrift voor Geneeskunde 129 (48): 2292-2293.

Till-d'Aulnis de Bourouill, H.A.H. van

1970 Medisch-juridische aspecten van het einde van het menselijk leven. Deventer: Kluwer.

1972 'Euthanasie en Recht.' Nederlands Tijdschrift voor Gerontologie3 (3): 174-188.

1973 'Jurist en euthanasie.' Medisch Contact 28: 46-50.

Timmermans, S.

1998 'Resusicitation technology in the emergency department: towards a dignified deach.' Sociology of health and illness 20 (2): 144-167. 


\section{Timmermans, S. \& M. Berg}

1997 'Standardization in Action: Achieving Local Universality through Medical Protocols.' Social Studies of Science 27: 273-305.

\section{Tongeren, P. van}

1988 'Ethiek en Praktijk.' Filosofie of praktijk 3 (9): I13-I27.

Trappenburg, M.J.

1993 Soorten van gelijk: medisch-ethische discussies in Nederland. Zwolle: W.E.J.

Tjeenk Willink.

Tweede Kamer

1991-92'Handelingen Tweede Kamer.' 's-Gravenhage.

Veen, R.J. van der

1990 De sociale grenzen van beleid; een onderzoek naar de uitvoering en effecten van het stelsel van sociale zekerheid. Leiden: Stenfert Kroese.

Ven, F.J.H.M. van de

1957 Sociale grondrechten. Mens en medemens. Aspecten der sociale werkelijkheid. Utrecht/Antwerpen: Het Spectrum.

Verbogr, S.

1992 Hoofdstukken over gezondheidsrecht. Arnhem: Gouda Quint.

Verbrugh, H.S.

1978 Paradigma's en begripsontwikkeling in de ziekteleer. Haarlem: De Toorts.

Verkerk, $M$.

1994 'Zorg of contract: een andere ethiek.' In: H. Manschor \& M. Verkerk, Ethiek van de zorg; een discussie. Amsterdam: Boom. Pp. 53-74.

1997 Denken overzorg. Concepten en praktijken. Utrecht: Elsevier/De Tijdstroom.

Visser, $\mathrm{J}$.

2001 'De relatie tussen lijden en ziekte.' Medisch Contact 45 (56): 1644-1647.

Vries, G. de

1981 'De besmettelijkheid van intellectueel contact.' Kennis en Methode 2 (5): 156164.

1993a Gerede twijfel. Over de rol van de medische ethiek in Nederland. Amsterdam: De Balie.

1993b 'Medisch-ethici zijn overbodige amateur-juristen.' de Volkskrant.

Vries, R. de \& J. Subedi (eds)

1998 Bioethics and Society. Constructing the Ethical Enterprise. Upper Saddle River: Prentice-Hall.

VWS

200r 'Agenda Ethiek en Gezondheid.' E. Borst-Eilers. Den Haag: Ministerie van Volksgezondheid, Welzijn en Sport.

Weisz, G.

1990 Social science perspectives on medical ethics. Dordrecht: Kluwer Academic Publishers.

Wellen, D.J.

I971 'Van de conferentierafel.' Metamedica: 62-66. 
Weyers, $\mathrm{H}$.

2001 'Euthanasia: The process of legal change in the Netherlands. The making of the 'requirements of careful practice.' In: A. Klijn \& M. Otlowski et al., Regulating physician-negotiated death. 's-Gravenhage: Elsevier. Pp.II-27.

Widdershoven, G.

1999 'Eerste ervaringen van toetsingscommisies euthanasie.' Medisch Contact 54 (29/30): 1035-1037.

Widdershoven, G.A.M.

2000 Ethiek in de kliniek. Hedendaagse benaderingen in de gezondheidsethiek. Maastricht: Boom.

Wierdsma, A.R.

1969 'Elk geval op eigen mérites beoordelen.' Medisch Contact 24 (18): 503.

Wijmen, F.C.B. van

1996 'H.J.J. Leenen, Handboek Gezondheidsrecht. Deel I: Rechten van mensen in de gezondheidszorg.' Themis 2: 77-79.

Wijmen, F.C.B. van \& H.A.M.J. ten Have et al.

1994 'Medische ethiek en gezondheidsrecht in het Nederlands medisch onderwijs. II. Gezondheidsrecht.' Nederlands Tijdschrift voor Geneeskunde 38 (8): 418-422.

Wilde, R. de

1992 Discipline en Legende. De identiteit van de sociologie in Duitsland en de Verenigde Staten 1870-1930. Amsterdam: Van Gennep.

Wilensky, H.L.

1964 'The Professionalization of Everyone?' American Journal of Sociology 70 :

Willems, D. $137-158$.

1995 'Hier met de ethiek!' Krisis 6r (15): 94-97.

Willigenburg, $T$. van

1993 'Ik ben een ethisch ingenieur!' In: F.W.A. Brom, B.J. van den Bergh et al., Beleid en ethiek. Assen: van Gorcum.

Willigenburg, T. van \& A. van den Beld et al.

1993 Ethiek in praktijk. Assen: Van Gorcum.

Wolf, S.M.

1994 'Shifting Paradigms in Bioethics and Health Law: The Rise of a New Pragmatism.' American Journal of Law and Medicine 20 (4): 395-415.

Wöretshofer, J.

1987 'Het tweede advies van de Raad van State inzake euthanasie.' Delikt en Delinkwent 17 (8): 840-848.

1992 'Het kabinetsstandpunt inzake medische beslissingen rond het levenseinde.' Delikt en Delinkwent 22 (8): 785-797.

Zuckerman, $\mathrm{H}$.

1988 'The sociology of science.' In: J.N. Smelser, Handbook of Sociology. Newbury Park: Sage. Pp. 5II-574.

Zwart, H.

1992 'Is medische ethiek ethiek?' Tijdschrift voor Geneeskunde en Ethiek2 (2): 34-37. 
1993a 'Centrum voor Ethiek Katholieke Universiteit Nijmegen.' Ethische perspectieven 3 (2): II2-II6.

1993b Ethische consensus in een pluralistische samenleving. De gezondheidsethiek als casus. Amsterdam: Thesis Publishers.

1995 Weg met de Ethiek? Filosofische beschouwingen over geneeskunde en ethiek. Amsterdam: Thesis Publishers.

1998 'Beelden en woorden: Het eerste hoofdstuk van de 'nieuwe' medische ethiek.' Tijdschrift voor Geneeskunde en Ethiek 8 (r): 8-13. 
8 


\section{SUMMARY}

Is it true that ethicists and lawyers always lag behind in medical-ethical debates? A common criticism on the role of ethics and law in health care is that these disciplines follow debates instead of having effect on them. This criticism will be challenged in this thesis. Ethicists and lawyers are not just or not only activated after a policy problem has been outlined. On the contrary, they contribute to the demarcation of the problem by suggesting several definitions and by presenting concepts for discussing the issues at hand. Thus they do not only enter the scene when their advice is required. They exercise their influence long before, during the constitution of the conceptual framework for a policy problem.

Currently medical ethical debates are inconceivable without the input of health care ethicists and health care lawyers. However health care ethicists and health lawyers are a rather new phenomenon in the Netherlands. Since the sixties health care ethics and health law have developed as scientific disciplines. From then on ethicists and lawyers have, with varying degrees of success, gradually involved themselves in medical ethical debates. Today their voice, for example their focus on patient protecrion and patient rights, is an established part of this type of debate. The medical profession no longer has an exclusive say in medical ethical matters.

How have both disciplines developed and how are they related to each other? This is the central question in this thesis. In the eighties critics of both the relation between health care ethics and health care law, and developments in ethics gave rise to this question. These critics included ethicists as well as lawyers. According to some of them the two disciplines were too entangled with one another and as a consequence it was hard to distinguish between ethics and law: they were like Siamese twins. Ethicists also heaped criticism on each other concerning some developments in health care ethics. Some ethicists complained that health care ethics was too solution oriented, instead of being reflexive or philosophical: ethicists as amateur-lawyers or proto-juridical ethics. 
This study aims to give insight into the development of and relation between the disciplines of health care ethics and health law. 'To narrow this broad aim, the thesis focuses on end-of-life decisions in the Netherlands 1960-1994. It was decided to analyze the case of discussions about end-of-life decisions in order to study both disciplines 'in action'. In chapter two it is argued that the self-image of disciplines, their inside stories about and justifications for their discipline, is too limired to study the development of and relation between the two disciplines. Self-images do not pay enough attention to the amount of work put in by ethicists and lawyers to develop their discipline. In order to show this work a focus on a single case-study was needed.

The debate about end-of-life decisions is considered one of the arena's in which both ethicists and lawyers have worked hard to develop their disciplines. This study stresses the close connection between the development of both disciplines and social developments. This close connection was unraveled with empiricalhistorical research into ethics and law, using three different theoretical perspectives: sociology of professions (chapter three), history of science (chapter four) and science and technology studies (chapter five). Literature from the professional debate about end-of-life decisions, that is monographs and journals in which ethicists and lawyers have published, has been analyzed. Furthermore interviews with key-persons within ethics, law and medicine were held. In general this study underlines the interaction between ethics and law and the professional debate. As a consequence of this interaction there is no permanent or fixed relationship between ethics and law. One cannot simply speak of two separate disciplines with either a harmonious or a competitive affiliation.

After the two introductive chapters, chapter three focuses on the way ethicists and lawyers have contributed to the current definition of euthanasia. The framework used to study these dynamics highlights the aspects of jurisdiction (Abbott) and the assignment of responsibilities (Gusfield). The question at issue here is who is in control of issues of end-of-life, when and how this came to be the case and who or what is responsible for this situation.

Efforts to control the debate and the assignment of responsibilities are both different ways to mould the debate. The mutual struggle and competition between the actors involved constructs the debate. And vice versa the debate affects the position and claims of the actors. In the fifties and sixties the rapid progress of medical technology raised new questions and uncertainties for the medical profession. This opened up possibilities for ethicists and lawyers to claim jurisdiction in medical ethics. Ethicists and lawyers not only competed with the medical profession about medical ethics but also with each other. In discussions about the definition of euthanasia and in the demarcation of the 
debate, the actors' positions altered continually. Proposals for a definition and possible solutions for the issues raised resulted in subtle changes in jurisdiction. The jurist Leenen for example, was dedicated to make a distinction between euthanasia, defined by him as 'a deliberate life-shortening action by someone else at request of the person in question', and non-euthanasia. With noneuthanasia he meant for example stopping a medically useless treatment, 'eurhanasia' in the case of newborn child's, indirect euthanasia, and the refusal of a medical life-saving treatment.

The demarcation of the problem at the same time involves the assignment of responsibilities for that problem. Ethicists concentrated on the reflexive framework of the debate whereas lawyers applied themselves to proposing a definition of euthanasia. As a consequence lawyers dominated the debate in the eighties. In the nineties however, new issues were raised in the debate, for example end-of-life decisions without request (new born child's, Alzheimer patients) became a topic of discussion. This was an opportunity for ethicists to expand their jurisdiction. Some ethicists, for example Zwart, were more dedicated to put these issues on the agenda than to try and find a solution for them. This chapter illustrates the dynamics in the development of health care ethics and health law. The debate about end-of-life decisions creates chances for ethicists and lawyers to form an identity in the way they marked the problem and claimed jurisdiction.

Chapter four analyses the conceptual development in ethics and law related to the position of the patient in end-of-life issues. To do this the concepts 'thoughtstyle' and 'paradigm' are used. These concepts were introduced respectively by Fleck and Kuhn, both philosophers of science. The concept of thoughtstyle is helpful to describe conceptual developments during periods of crisis, whereas the concept of paradigm is useful to describe developments in the history of science. The central question in this chapter is whether the two disciplines each have their own thoughtstyle or whether they share a thoughtstyle. Both disciplines, as this analysis illustrates, have their roots in a period when the 'old paradigm' of medical ethics as professional codes, was being questioned.

In this old paradigm, which was common until the end of the sixtics, parients had a passive role in matters of health. The paradigm was not sufficienr for interpreting, describing and therefore solving the dilcmma's raised by a ncw category of patients: namely patients who received continually treatment which lead to an extended deathbed instead of an extension of their lives. In the next period two new and competitive thoughtstyles developed shared by both ethicists and lawyers: the social-philosophicalview and the individual-humanistic view. Both tried to find a solution for the problem of 'medical power' (patcr- 
nalism). These solutions varied, the social-philosophical view was focused on the physician-patient relationship within a social context with for example questions about the meaning of life and the person behind the patient, whereas the individual-humanistic view focused solely on the patient and his rights. The last, with a strong focus on patient autonomy, turned out to be the most promising view for solving end-of-life issues. As a consequence the social-philosophical view, with the catholic theologian Sporken as its key-author, shifted to the margin of the debate. In the eighties patient autonomy became the basic assumption for dealing with end-of-life issues for example in courts, but also within health care ethics and health law. Thus in the eighties patient autonomy had become a shared thoughtstyle. Within health law under influence of the lawyer Leenen and within health care ethics, for example used by the protestant theologian Dupuis. In the nineties, however, patient autonomy appeared not to be the panacea for all end-of-life issues, especially not in the case of end-of-life issues without request. Lawyers considered life-ending decisions in the case of non-autonomous patients, - for example; severely handicapped new born child's, Pvs-patients, psychiatric patients and Alzheimer patients, - as a different problem, whereas ethicists tried to integrate this issue in the debate about end-of-life decisions. The ethicist Kuitert pleaded in this context for 'mercykilling' and applied the rule: a good physician spares his patient a bitter end. Different views held by ethicists on how to deal with non-autonomous parients opened up possibilities for a new thoughtstyle including value judgements by physicians. While in the common paradigm solely objective judgements and the will of the patient were valid arguments. Health care ethics and health law therefore do not evidently share a thoughtstyle, nor are their thoughtstyles evidenty different.

In chapter five the relationship between ethics and law is studied by opening the black box of the so called requirements of careful practice. The requirements of careful practice is a concept specifically used to the standardize and regulate the Dutch practice of euthanasia. Basically, these requirements deal with the patient's request, the patient's suffering and the doctor-patient relationship. The role of ethics and law in constructing these requirements is studied by making a network analysis as demonstrated by the anthropologist of science Latour.

In order to understand the construction of (new) knowledge one has, according to Latour, to examine how knowledge claims become embedded in a specific infrastructure or network. It is only within a stable network of heterogeneous relations and after the construction of several nodes that standardization and regulation can succeed. The analysis illustrates that the requirements of careful practice can not be constructed based upon ready made knowledge within ethics or law. On the contrary, they are the result of constructing a network around 
end-of-life issues. Norms and rules for euthanasia are established together with and in relation to developments in the practice for end-of-life decisions.

Euthanasia was organized and conceived in a particular way which eventually led to some nodes in constructing a (material) network around end-of-life decisions. For example the fact that end-of-life decisions can only be made by physicians provided that they have followed the requirements of careful practice. In the seventies this was not common practice. At that time it was still open who under what conditions could or should be allowed to deal with end-of-life issues. In the network of end-of-life decisions, ethics nor law has a fixed or predetermined role. This chapter illustrates that law does not necessarily follow ethics. The relation between ethics and law is established time and again, as a result of several nodes in the constructed network. In the eighties ethicists and lawyers for instance tried to find ways in dealing with the legal insecurity and the legal inequality which followed from the jurisprudence. They both explained verdicts and 'applied' them to new cases.

In the final chapter the role and position of health care ethics and health law in medical ethical debates is discussed. Borh disciplines, according to a common criticism, follow debates whereas they should reflect critically upon them. This study shows that ethics and law not only play a role in a later stage, when advice is given for certain policy problems. The efforts made by ethicists and lawyers in the debate about end-of-life decisions have contributed to a certain body of concepts which has influenced the standardization and regulation of euthanasia. Thus the notion that ethics and law are always too late in medical-ethical debates is a misconception. One cannot debate a policy problem as a blank problem, because it is a problem that has yet to be defined and conceptualized. Before they can give advice on these issues, ethicists and lawyers have already done a substantial amount of work.

This conclusion is illustrated by a brief discussion about the 'tired-with-life issues'. The debate about these issues was started in the nineties with a discussion abour 'Drion's pill'. Drion, a former professor of law and a former councilor of the Supreme Court, had suggested that elderly people should have the right to be supplied with a 'pill' with which they could choose their own death. The most recent case about end-of-life issues is the Brongersma case. This case has so far led to several developments in ethics and law, for example a discussion about the role of respect for patient autonomy and responsibilities of the physician in these new issues. However, this study illustrates that there is no endless variety of possibilities to anticipate developments. Possibilities to anticipate are restricted to the network under construction.

Empirical research in the context of a moral issues can tell which are the claims and where do they come from. A comprehensive understanding of the 
role and interaction berween ethics and law in medical-erhical debares can be acquired by using the theoretical perspective as developed in the three different analyses. This links up with recent initiatives from the government to anticipare more to ethics and law in medicil ethical debates. 


\section{SAMENVATTING}

Lopen ethiek en recht achter de feiten aan in medisch-ethisch debatten? Een veelgehoorde klacht over de rol van ethiek en recht in de gezondheidszorg is dat ze het debat volgen in plaats van het te bepalen en te beïnvloeden. Deze kritiek wordt in dit proefschrift genuanceerd weerlegd. Ethici en juristen komen niet pas in actie wanneer er een afgebakend beleidsprobleem ligt, maar zij dragen juist bij aan de afbakening van het probleem door middel van definitievoorstellen en het aanleveren van concepten waarin over kwesties wordt gesproken. Er is dus voor ethici en juristen niet alleen in de adviesfase een rol weggelegd. Zij oefenen al eerder, tijdens de vorming van het begrippenkader van een beleidsprobleem, hun invloed uit.

Medisch-ethische debatten zijn tegenwoordig ondenkbaar zonder de inbreng van ethische en juridische professionals. Gezondheidsethici en gezondheidsjuristen zijn echter een relatief nieuw fenomeen; tussen de dertig en veertig jaar geleden zijn de vakgebieden gezondheidsethiek en gezondheidsrecht zich in ons land gaan ontwikkelen. Sindsdien hebben ethici en juristen zich in toenemende mate en met wisselend succes in medisch-ethische debatten gemengd. De opkomst van de vakgebieden gezondheidsethiek en gezondheidsrecht betekende tegelijk het einde van de monopoliepositie van de medische professie inzake medisch-ethische kwesties.

De vraag is hoe beide disciplines zich de laatste vier decennia ontwikkeld hebben en hoe ze zich tot elkaar verhouden. Deze vraag vormt het uitgangspunt van dit proefschrift. Aanleiding hiervoor was de kritiek die eind jaren tachtig te horen was over de verhouding tussen ethiek en recht. Die kritiek kwam zowel van ethici als juristen. Gezondheidserhiek en gezondheidsrecht zouden volgens de critici te veel naar elkaar toe gegroeid en met elkaar verstrengeld zijn, ze zouden onderling verbonden zijn als een Siamese tweeling. Dit was voor sommige ethici aanleiding om op bepaalde ontwikkelingen van hun vakgebied kritisch te reflecteren. Zij verzetten zich fel tegen de, in hun ogen, ongewenste richting die de ethiek had ingeslagen. Medische ethiek was verworden tot smalle, oplossingsgerichte ethiek in plaats van brede, meer reflexieve ethiek. Ethici gingen zich te veel als juristen gedragen door in hun beschouwingen al te anticiperen op juridische regelingen, waarmee ze voorbij gingen aan ethische en filosofische discussies. Ethici dus als 'amateur-juristen', ofwel proto-juridisering van de ethiek. 
Aan de hand van het professionele debat over levensbeëindigend handelen in Nederland in de periode 1960-1994 geeft dit onderzoek inzicht in de ontwikkeling van en de verhouding tussen de disciplines gezondheidsethiek en gezondheidsrecht. Er is gekozen voor een case-study, omdat daarmee beide disciplines 'in actie' - in discussies over levensbeëindigend handelen - bestudeerd kunnen worden. In hoofdstuk twee wordt betoogd dat het zelfbeeld van de vakgebieden, dat wil zeggen de interne verhalen en verklaringen over de eigen ontwikkeling, tc beperkt is om de ontwikkeling van en verhouding tussen beide disciplines te kunnen bestuderen. Het werk dat daadwerkelijk is verzet om het vakgehicd vorm en inhoud tc geven wordt in het zelfbeeld onderbelicht. Het debat over levensbeëindigend handelen, de case-study, is in dit geval dus nodig om te laten zien welke specifieke arbeid ethici en juristen verrichten.

Her debar over levensbeëindigend handelen is in dit onderzoek als één van de arena's beschouwd waar ethici en juristen zich hebben ingespannen voor de ontwikkeling van hun disciplines. Deze studie benadrukt de samenhang tussen de ontwikkeling van beide disciplines en de maatschappelijke ontwikkelingen. Aan de hand van drie verschillende theoretische perspectieven is empirischhistorisch onderzoek verricht naar gezondheidsrecht en gezondheidsethiek: de professiesociologie (hoofdstuk drie), de wetenschapsgeschiedenis (hoofdstuk vier) en het sociologisch wetenschapsonderzoek (hoofdstuk vijf). Het betreft een literatuuronderzoek naar het professionele debat over levensbeëindigend handelen. Dat wil zeggen dat monografieën en tijdschriften waarin door ethici en juristen wordt gepubliceerd zijn onderzocht. Aanvullend op het literatuuronderzoek zijn interviews gehouden met sleutelfiguren uit ethiek, recht en geneeskunde. Dit onderzoek laat zien dar de relatie tussen recht en ethiek wordt bepaald in samenhang met de ontwikkelingen in het debat. Er kan dan ook niet gesproken worden over twee eigenstandige disciplines met herzij een harmonieuze, hetrij een competitieve relatic.

De wijze waarop ethici en juristen hebben meegewerkt aan het tot stand komen van de definitie voor euthanasie vormt het onderwerp van hoofdstuk drie. Vanuit professie-sociologisch perspectief, geinspireerd door analyses van de professiesocioloog Abbott en de symbolisch-interactionistisch socioloog Gusfield, is onderzocht wie, wanneer en op welke manier zeggenschap claimt over vragen rond het levenseinde en wie of wat verantwoordelijk wordt geacht voor het ontstaan en het oplossen ervan.

Het toe-eigenen van zeggenschap en de verdeling van verantwoordelijkheden rond het levenseinde zijn verschillende manieren om de praktijk vorm te geven. De onderlinge strijd en concurrentie tussen actoren zijn van invloed op het debat. En andersom geldt dat het debat van invloed is op de manier waarop 
door de actoren zeggenschap wordt geclaimd. De snelle ontwikkelingen in de medische technologie riepen nieuwe vragen en onzekerheden op voor de medische professie. Dit bood ethici en juristen mogelijkheden om zeggenschap te claimen op het terrein van de medische ethiek. In discussies over de definitie van het begrip euthanasie en tijdens de afbakening van het terrein van het debat vond (her)positionering van de actoren plaats. Subtiele verschuivingen in zeggenschap treden op via definitievoorstellen en het aandragen van oplossingen. De jurist Leenen maakte zich bijvoorbeeld sterk voor een onderscheid tussen euthanasie, door hem gedefinieerd als 'een opzettelijk levensverkortend handelen door een ander dan de betrokkene op diens verzoek' en schijngestalten van euthanasie. Onder de laatste rekende hij onder meer het staken van een zinloze medische behandeling, 'euthanasie' bij pasgeborenen, indirecte euthanasie en het weigeren van een medische behandeling.

Tegelijk met de afbakening van het probleem vindt er een competentiestrijd plaats en een toekenning van de verantwoordelijkheden voor het probleem. Daarbij concentreren ethici zich meer op het beschouwende kader van de discussie, terwijl juristen zich meer toeleggen op het formuleren van definitievoorstellen en het specificeren van verantwoordelijkheden. Daardoor hebben juristen in de jaren tachtig meer grip op de vorm en inhoud van het debat dan ethici. In de jaren negentig worden in het debat nieuwe issues opgepakt waardoor 'oude' afbakeningen ter discussie worden gesteld, bijvoorbeeld levensbeëindiging met of zonder verzoek (pasgeborenen, demente patiënten). In die periode profileren zich ethici die eerder geneigd zijn problemen op de agenda te zetten dan ze onmiddellijk op te lossen, zoals de ethicus Zwart. Door de meer open manier waarop ethici in het debat interveniëren krijgen zij op hun beurt weer meer zeggenschap. Dit hoofdstuk laat de dynamiek in de ontwikkeling van beide vakgebieden zien. Gezondheidsrecht en gezondheidsethiek hebben geen vaste identiteit. Het debat over de kwesties rond het levenseinde vormt voor ethici en juristen een kans zich een identiteit te vormen in de manier waarop ze proberen het probleem af te bakenen en zeggenschap te verwerven.

Aan de hand van de theoretische concepten 'denkstijl' en 'paradigma' ontleend aan de wetenschapsfilosofen Fleck en Kuhn wordt in hoofdstuk vier de conceptuele ontwikkeling binnen gezondheidsethiek en gezondheidsrecht. Daarbij staan ontwikkelingen in de positie van de patiënt bij levensbeëindigend handelen centraal. Het begrip denkstijl biedt houvast om het werk van ethici en juristen met betrekking tot begripsontwikkeling tijdens een crisisperiode te beschrijven. Het begrip paradigma is geschikt om de afwisseling tussen periodes van crisis en normale wetenschap te beschrijven. Onderzocht is of er sprake is van twee verschillende denkstijlen voor de twee vakgebieden, of juist van een gedeelde of deels overlappende denkstijl. Deze sociaalconceptuele analyse laat 
zien dat beide vakgebieden tot ontwikkeling zijn gekomen in een fase waarin het 'oude' paradigma, van medische ethiek als een set van beroepscodes, in twijfel werd getrokken. In dit oude paradigma, dat tot ver in de jaren zestig gangbaar was, had de pariënt een passieve rol in beslissingen over ziekte en gezondheid. Dit paradigma bleek niet toereikend te zijn voor het interpreteren, beschrijven en daarmee oplossen van de dilemma's rond de nieuwe categorie patiënten - de steeds maar doorbehandelde patiënten waarvan eerder het sterfbed dan het leven werd verlengd.

In de periode daarna komen twee nieuwe en concurrerende denkstijlen op bij zowel ethici als juristen: de sociaal-levensbeschouwelijke en de individueelhumanistische denkstijl. Bij de eerste staat het brede overleg en de gezamenlijke uitdieping van kwesties rond het levenseinde voorop, zoals zinvragen en het benadrukken van de sociale context van de mens achter de patiënt. De laatste, waarin het idee van zelfbeschikking van de patiënt centraal staat, groeide echter uit tor het 'standaard' denkkader voor zowel ethici als juristen. Daarmee verschuift de sociaal-levensbeschouwelijke denkstijl, met als sleutelauteur de katholieke moraaltheoloog Sporken, naar de marges van het debat. Zelfbeschikking van de patiënt wordt gebruikt als uitgangspunt voor de aanpak van problemen zoals in rechtszaken, maar ook als de centrale norm binnen gezondheidsrecht en gezondheidsethiek. De arts hoeft geen oordeel over de zin of kwaliteit van leven van de patiënt te geven, dit wordt aan de patiënt zelf overgelaten. Het idee van bescherming van de patiënt door middel van respect voor autonomie en het recht op zelfbeschikking is een gedeelde denkstijl die in de jaren tachtig uitgroeide tot een gemeenschappelijk paradigma voor gezondheidsrecht en gezondheidsethiek. Binnen het gezondheidsrecht gebeurde dit onder invloed van de jurist Leenen en binnen de gezondheidsethiek is de autonomie van de patiënt onder meer uitgewerkt door de liberaal georiënteerde ethica Dupuis. Deze denkstijl komt echter onder druk te staan als in de jaren negentig het debat over levensbeëindiging in geval van wilsonbekwaamheid op gang komt. Juristen zien het probleem van levensbeëindiging bij wilsonbekwamen als een probleem 'apart' van het euthanasiedebat, terwijl ethici dit juist in het debat willen integreren. De ethicus Kuitert hield in dit verband een pleidooi voor het argument van barmhartigheid en introduceerde de stelregel: een goede arts bespaart zijn patiënt het bittere einde. De verschillende visies op kwesties rond de wilsonbekwame patiënt leiden bij de ethici tot openingen voor een nieuwe denkstijl. In deze denkstijl is meer ruimte voor waardeoordelen door artsen, terwijl in het gemeenschappelijke denkkader alleen objectieve oordelen en de wil van de patiënt als argument golden. Gezondheidsrecht en gezondheidsethiek hebben dus geen vanzelfsprekend gedeelde, maar ook geen vanzelfsprekend verschillende denkstijl. 
In hoofdstuk vijf is onderzocht hoe normering en regulering rond levensbeëindigend handelen tot stand zijn gekomen, en hoe recht en ethiek daarbij een rol hebben gespeeld. Hiervoor is gebruik gemaakt van een netwerkanalyse zoals uitgewerkt door de wetenschapsantropoloog Latour. Door uit te gaan van de actornetwerktheorie over het tot stand komen van normen en regels, is het mogelijk om de totstandkoming van de zorgvuldigheidseisen te onderzoeken. De zorgvuldigheidseisen voor euthanasie verwijzen naar een pakket van eisen waaraan een arts moet voldoen bij de toepassing van euthanasie, bijvoorbeeld controleren of er sprake is van een duurzaam en vrijwillig verzoek. Dit pakket van eisen kan als het voorlopig resultaat van een zoektocht naar nieuwe normen en regels voor levensbeëindigend handelen worden beschouwd. De analyse laat zien dat de zorgvuldigheidseisen niet op basis van een bepaalde stand van zaken binnen de ethiek of het recht zijn geconstrueerd, maar het resultaat zijn van de wijze waarop rond levensbeëindigend handelen een netwerk ontstaat. Normen en regels voor euthanasie ontwikkelen zich tegelijkertijd en in samenhang met een uitvoeringspraktijk voor levensbeëindigend handelen in een medische context.

Daarbij vormt zich een orde met bepaalde knooppunten op basis van jurisprudentie, adviezen, rapporten en voorstellen. Een voorbeeld van deze knooppunten is dat euthanasie alleen door een (behandelend) arts mag worden toegepast op voorwaarde dat de zorgvuldigheidseisen in acht zijn genomen. Dit was in de jaren zeventig nog geen gemeengoed, toen lag nog relatief open wie onder welke omstandigheden euthanasie zou mogen toepassen.

Rond deze twee harde feiten, de arts en de zorgvuldigheidseisen, wordt ook een materieel netwerk gespannen. Materiële zaken zoals de meldingsprocedure krijgen de functie van een protocol of standaard voor het toepassen van euthanasie. In dit netwerk wordt de verhouding tussen recht en ethiek bij de ontwikkeling van normering en regulering telkens opnieuw bepaald, afhankelijk van de wijze waarop in het netwerk knooppunten tot stand zijn gekomen. Ethici en juristen proberen bijvoorbeeld in de jaren tachtig manieren te vinden om om te gaan met de rechtsonzekerheid en rechtsongelijkheid die met de verschillende uitspraken van rechtbanken in zake euthanasie gepaard gaat. Ze geven kritiek op diverse ontwikkelingen, ze leggen uitspraken van rechtbanken uit en vertalen deze naar nieuwe casus. Dit hoofdstuk illustreert dat er geen vaste rol of taakverdeling is voor ethiek en recht in medisch-ethische debatten. Het recht volgt zeker niet altijd de ethiek, zoals soms wordt verondersteld.

In het slothoofdstuk wordt de betekenis van gezondheidsethiek en gezondheidsrecht in medisch-ethische debatten besproken. Een veel gehoorde klacht over beide disciplines is dat ze niet kritisch genoeg reageren op ontwikkelingen in medisch-ethische debatten en achter de feiten aanlopen. Dir beeld van ethiek en recht wordt versterkt door de adviesrol van ethici en juristen bij beleid inzake 
Alle geïnterviewden, uit de ethiek, het recht en de geneeskunde dank ik voor hun tijd en de ervaringen die ze me wilden meegeven. Zij hebben geholpen om de wereld achter de artikelen en boeken voor mij tot leven laten komen.

$\mathrm{Bij}$ de vele discussieplatforms die het academische leven rijk is heb ik weerklank en commentaar gevonden op mijn ideeën en stukken. Ik denk hierbij aan Technologie, Onderzoek en Normativiteit (TON) bij de vakgroep Gezondheidsethiek en Wijsbegeerte, de werkgroep Ethiek en Empirie, de bijeenkomsten van de onderzoeksschool Wetenschap en Techniek in de Moderne Cultuur (wTMC), de discussiegroep Medische Beslissingen rond het Levenseinde in Amsterdam en niet in het minst de aio-soep die in de afgelopen jaren een wisselende samenstelling heeft gekend. De aio-soep is een beproefd recept voor lange discussieavonden met interessante uitkomsten. Ik dank alle collega's, binnen en buiten de vakgroep, voor hun inspirerende commentaar en de bereidheid om met mij mee te denken. Naast collegialiteit heb ik ook veel vriendschap en plezier met jullie gedeeld. In het bijzonder wil ik Jessica Mesman, Jos Dure en Guido de Wert bedanken voor hun commentaar op enkele concepthoofdstukken. Ruth Benschop dank ik voor het controleren van de Engelse samenvatting. Mijn kamergenoten, Michiel van Dorp en later Nynke Wilbrink, ben ik dankbaar voor hun reddingsacties op momenten dat ik weer eens in de clinch lag met mijn computer.

Bij de basketbalvereniging heb ik sportieve vrienden getroffen die met mij de passie voor deze mooie sport delen. De wekelijkse trainingen, de wedstrijden en de toernooien die we samen hebben gespeeld leverden de perfecte combinatie van inspanning en ontspanning.

Met mijn twee paranimfen, Mirjam Pijnappels en Rita Struhkamp, heb ik van begin tot eind de wederzijdse ervaringen van het assistent-in-opleiding zijn beleefd en uitgewisseld. Het luisterend oor en de goede adviezen van Mirjam reikten tot ver over de disciplinaire grenzen van ons onderzoek. Onze hoogteen dieptepunten bleken verrassend genoeg veel overeenkomsten te vertonen. In Rita vond ik een trouwe meelezer met een bijzonder analysevermogen. I heb dankbaar gebruik gemaakt van haar heldere commentaar, dat me vaak verder heeft geholpen.

Rineke Zandvoort en Karin Oude Oosterik dank ik voor de lange vriendschap en hun belangstelling voor mijn onderzoekservaringen. Ik weet dat ik altijd op hun onvoorwaardelijke hulp en steun kan rekenen en dat is een fantastisch voorrecht. Mijn familie bleef altijd geïnteresseerd vragen of mijn 'studie' al af was en of er ook kans was dat we nog eens dichterbij zouden komen wonen. Hun vertrouwen dat het wel los zou lopen, heeft me gesterkt in het afronden van mijn onderzoek. Dat geldt in her bijzonder voor mijn ouders, die me van jongs af aan veel ruimte hebben gegeven om mijn eigen pad re kiezen. 
De steun van Hans is me zeer dierbaar. Hij heeft me het allergrootste vertrouwen gegeven in mijn eigen kunnen. $\mathrm{Zijn}$ humor is uniek, niet te evenaren en van onschatbare betekenis voor me. Het zorgde onder meer voor de nodige afstand tor het onderzoek, omdat ik soms wel eens vergat dat het welbeschouwd natuurlijk maar gewoon 'werk' is. In het laatste jaar heeft Rens daar ook een handje bij geholpen. Ons motto is, was en blijft: 'Samen naar het eind van de wereld en weer terug'. 


\section{CURRICULUM VitAE}

Loes Kater werd op 3 december 1971 in Deventer geboren. Na de lagere school in Boskamp ging ze in 1984 naar de Alexander Hegius scholengemeenschap in Deventer waar ze in 1990 haar diploma gymnasium B behaalde. Datzelfdc jaar begon ze met de studie Gezondheidswetenschappen aan de Universiteir Maastricht, waar ze voor de afstudeerrichting Beleid en Beheer koos. Nadat ze deze studie in 1994 met succes afrondde, ging een lang gekoesterde wens in vervulling door een grote reis te maken. Een jaar lang trok ze door Australië en NieuwZeeland. Na de reis besloot ze weer te gaan studeren en volgde ze van 1995 tot 1997 de verkorte studie Wijsbegeerte, met als afstudeerrichting Ethiek, aan de Universiteit van Amsterdam. Te combineerde dexe studie met vern parttime baan bij het Breed Platform voor Verzekeringen en Werk waar ze als helpdeskmedewerker voorlichting gaf aan mensen die zich als gevolg van hun gezondheidstoestand moeilijk kunnen verzekeren of een baan kunnen vinden. $\mathrm{Na}$ de studie Wijsbegeerte in Amsterdam verhuisde ze opnieuw naar Maastricht waar ze als Assistent in Opleiding bij de vakgroep Gezondheidsethiek en Wijsbegeerte aan de Universiteit Maastricht aan de slag ging. Daar verrichtte ze het onderzoek waarover in dit boek verslag wordt gedaan. Naast haar onderzoeksen onderwijsactiviteiten was ze drie jaar bestuurlijk actief als lid van de faculteitsraad van de Universiteit Maastricht, en maakte ze als aspirantlid twee jaar deel uit van de medisch-ethische commissie van het Radio Therapeutisch Instituut Limburg in Heerlen. Na het voltooien van haar proefschrift accepteerde ze in 2002 een baan als post-doc onderzoeker bij de leerstoelgroep Filosofie van Wetenschap en Techniek aan de Universiteit Twente. Daar werkt ze aan onderzoek naar ethische en bestuurlijke aspecten van genetische technologie ontwikkeling in het kader van het onderzoeksprogramma Ethiek en Beleid van de Nederlandse Organisatie voor Wetenschappelijk Onderzoek (Nwo). 

Medisch-ethische debatten zijn tegenwoordig ondenkbaar zonder de inbreng van gezondheidsethici en gezondheidsjuristen. Deze relatief nieuwe

specialisten hebben het monopolie van de medische professie bij medisch. ethische kwesties doorbroken. Gezondheidsethiek en gezondheidsrecht hebben. in korte tijd een bloeiende ontwikkeling doorgemaakt en zich een duidelijke positie verworven in medisch-ethische debatten. Echter er valt ook kritiek te beluisteren: zo zouden beide disciplines niet kritisch genoeg reageren, achter de feiten aanlopen en te zeer met elkaar vergroeid zijn.

Loes Kater heeft aan de hand van het euthanasiedebat de ontwikkelingen van beide disciplines onderzocht. De snelle ontwikkelingen die de medische technologie sinds de jaren zestig heeft doorgemaakt, bood ethici en juristen de mogelijkheid om zeggenschap te claimen op het terrein van de medische ethiek. In discussies over de definitie van het begrip euthanasie hebben juristen en ethici hun invioed laten gelden. Hun inspanningen in het debat over vragen rond het levenseinde hebben bijvoorbeeld sterk bijgedragen aan een conceptueel kader voor de normering en regulering van euthanasie. De veelgehoorde klacht dat ethici en juristen pas in actie komen als er al een afgebakend beleidsprobleem ligt, gaat volgens Kater niet. op. Ethici en juristen dragen juist bij aan de afbakening van het probleem door middel van definitievoorstellen. Voor hen is dus niet alleen in de: adviesfase een ro! weggelegd. Zij oefenen al eerder, al tijdens de vorming van het begrippenkader van een beleidsprobleem, hun invloed uit. Disciplines met dadendrang dus.

Loes Kater studeerde Gezondheidswetenschappen aan de Universiteit Maastricht en Wijsbegeerte aan de Universiteit; van Amsterdam. Zij werkt nu als post-doc onderzoeker bij de leerstoelgroep Filosofie van Wetenschap en Techniek aan de Universiteit Twente.
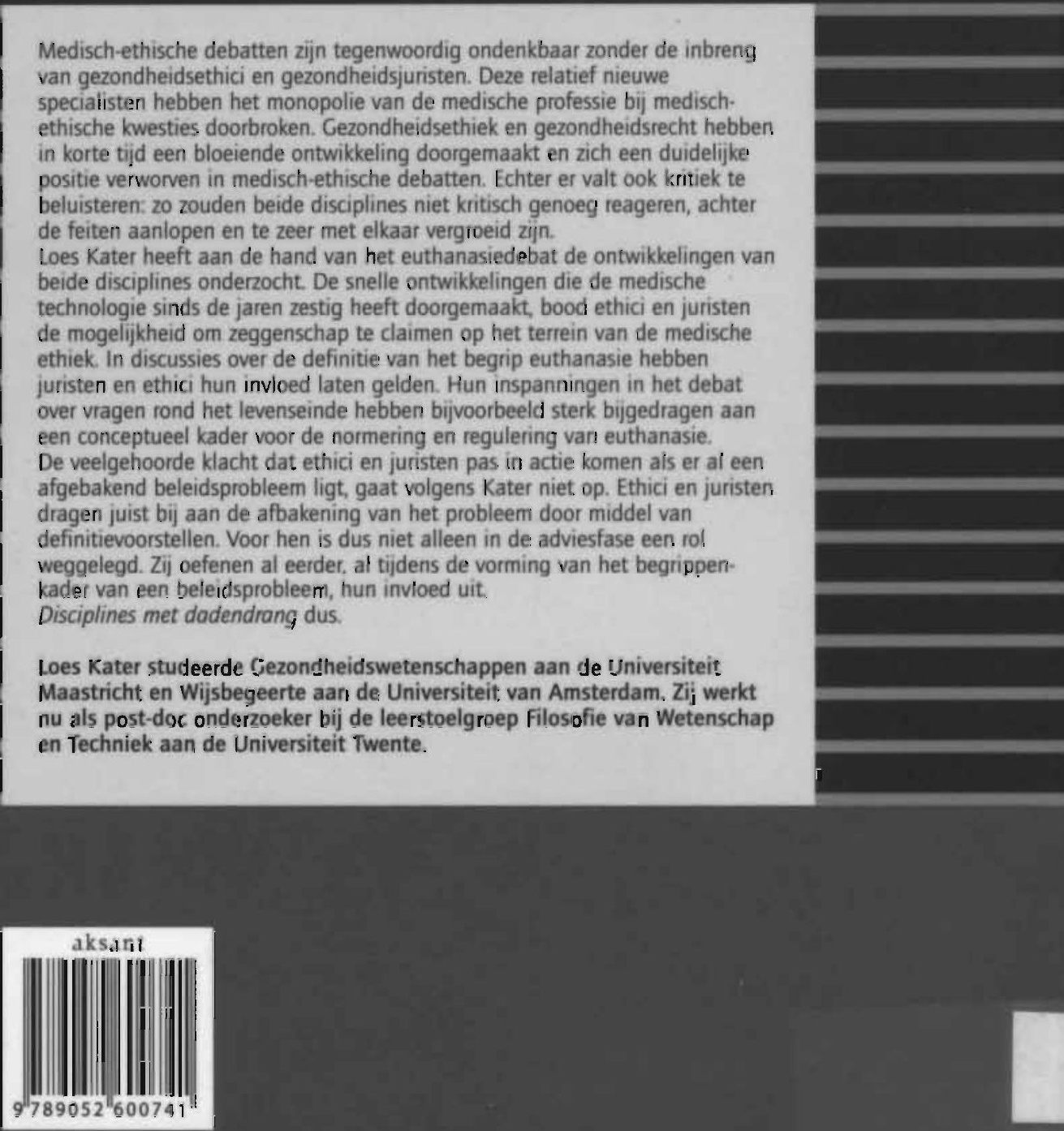